ERON ThE ENGrN

GEORGE GEIING OFTIL

RGE S. $\mathrm{YOTHE}$

DEPARTMENT OF THE INTERIOR

Albert B. FALL, Secretary

UNITED STATES GEOLOGICAL SURVEY

George Otis SMITH, Director

Professional PaPer 121

\title{
HELIUM-BEARING NATURAL GAS
}

BY

G. SHERBURNE ROGERS

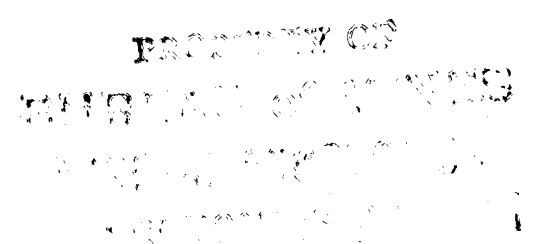

WASHINGTON

GOVERNMENT PRINTING OFFIOE

1921 


\section{DEPARTMENT OF THE INTERIOR \\ Albert B. FALL, Secretary \\ UNITED STATES GEOLOGICAL SURVEY \\ George OtIS Smith, Director}

Professional Paper 121

\section{HELIUM-BEARING NATURAL GAS}

BY

G. SHERBURNE ROGERS

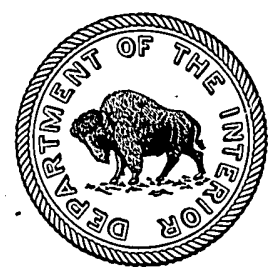

WASHINGTON

GOVERNMENT PRINTING OFFICE

1921 


\section{ADDITIONAL COPIES \\ OF THIS PUBLICATION MAY BE PROCURED FROM THE SUPERINTENDENT OF DOCUMENTS \\ GOVERNMENT PRINTING OFFICE WASHINGTON, D. C. \\ AT \\ 30 CENTS PER COPY}

$\nabla$

\section{$\bullet$}




\section{CONTENTS.}

Introduction.

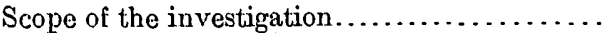

Value of helium for inflating balloons..........

Development of extraction processes..........

Acknowledgments........................

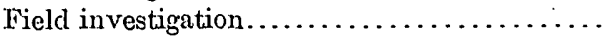

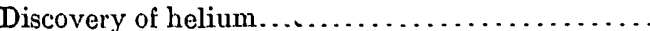

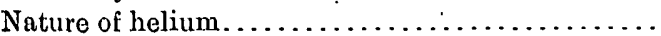

Properties of helium.....................

Relation of helium to the radio-elements......

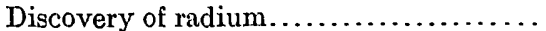

Theory of radioactivity................ The uranium-lead radioactive series...... The thorium-lead radioactive series....... Other radioactive series................ Rate of production of helium by the radioelements.

Association of helium with the rare gases. Distribution and relations of helium-bearing natural gas.

General outline.........................

Mid-Continent region.....................

Location.

General relations....................

Carboniferous formations.............

Pre-Carboniferous formations.......... Stratigraphic distribution of the helium... Variation in helium content with depth...

North Texas region.......................

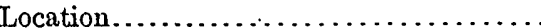

Geology.......................... Distribution of the helium..............

Appalachian region........................ Location.

Geology ...........................

Distribution of the helium..............

Rocky Mountain and Pacific coast regions....

Canada.

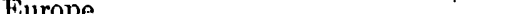

Summary of factors influencing the distribution of helium.

Chemical composition of helium-bearing natural gas.

Constituents of natural gas...................

Varieties of natural gas......................

Composition of helium-bearing gas.............

Determination of helium in natural gas........ Development of methods.

Apparatus and method of procedure, by C. W. Seibel.

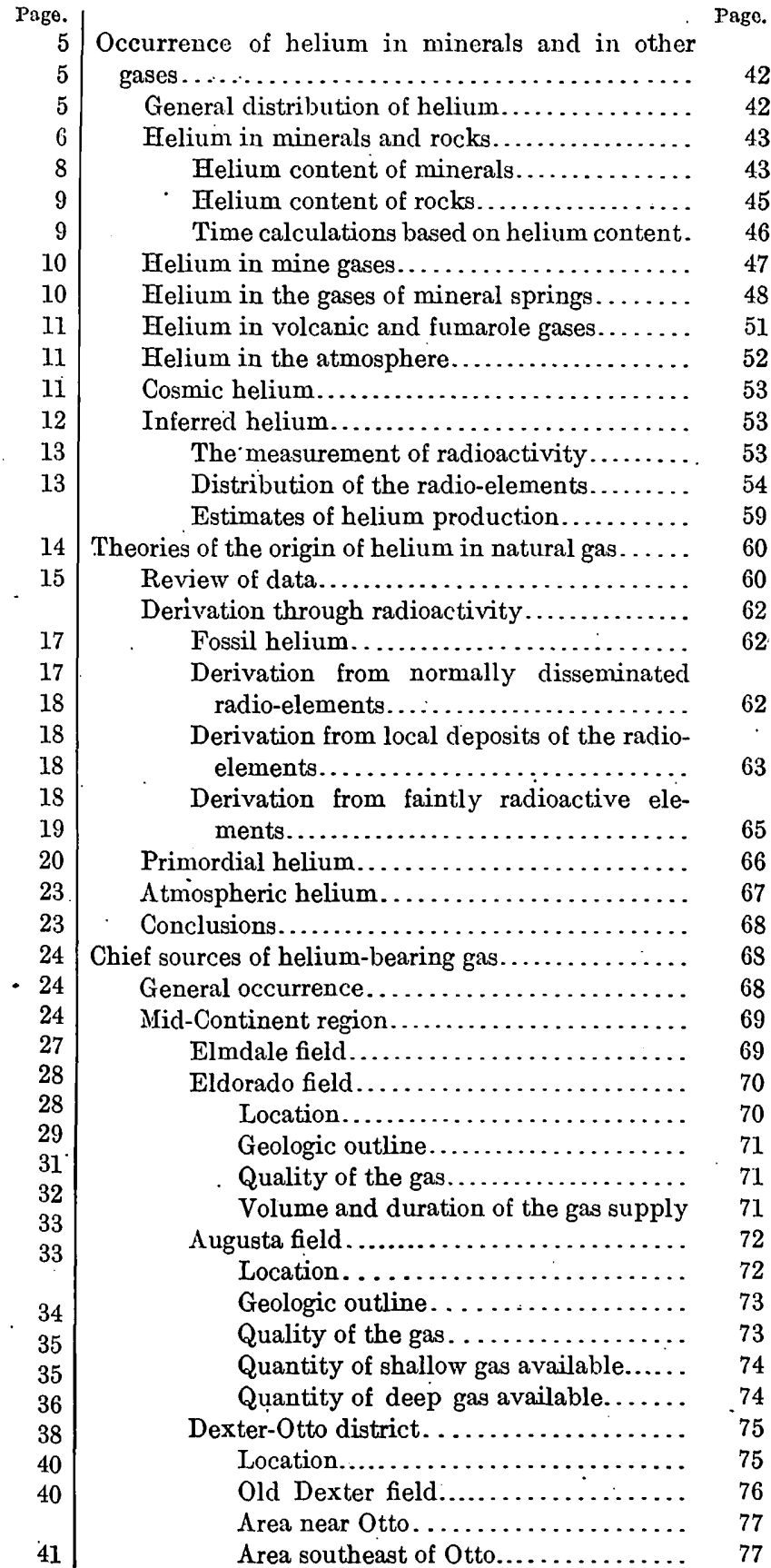


CONTENTS.

Chief sources of helium-bearing gas-Continued.' Mid-Continent region-Continued.

Sedan district.

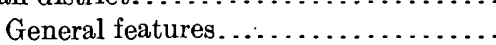

Rogers pool.....................

Area near Sedan.................

Monett field. ...................

Page. Chief sources of helium-bearing gas-Continued.

North Texas region.....................

Petrolia field . . . . . . . . . . . . . . . . .

Location and extent. . . . . . . . . . . .

Geologic outline.................

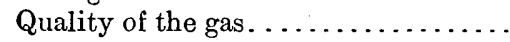

Production of the field..............

Duration of the supply.............

Possibility of extensions of the field...

Pearson field

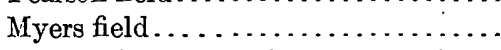

Prospective fields in western Osage

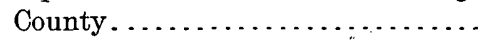

Other Mid-Continent fields.............

Minor fields in Kansas. . . . . . . . . . .

Minor fields in Oklahoma.

77

77

79

81

81

81

82

82

83

Other fields in northern Texas............

Appalachian region. . . . . . . . . . . . . . . .

Rocky Mountain and Pacific coast regions.....

A vailable supply of helium in the United States

Possible sources of helium in other countries...

Samples of natural gas tested for helium ...........

Index...

Page.

\section{ILLUSTRATIONS:}

Prate I. Map of gas fields in southern Kansas and northern Oklahoma, showing distribution and quality of helium-bearing gas.

II. Geologic map of Mid-Continent region, showing relations of helium-bearing area...

III. Map of oil and gas fields in northern Texas and southern Oklahoma, showing distribution of helium-bearing gas and relation of fields to areas of uplift.

IV. Apparatus used in quantitative determination of helium.

Figure 1. Index map showing general distribution of națural.gas rich in helium..........

2. Generalized section of formations in eastern Kansas.

3. Map of portion of eastern Kansas showing depth and relations of the granite ridge..........................

4. Generalized columnar section of formations in north-central Texas..........

5. Map showing the geologic relations of the Ohio area of helium-bearing gas. .

6. Columnar section of rocks exposed and encountered in drilling in south-central Ohio.

7. Diagram showing relation of helium to nitrogen in 50 samples of natural gas. .

Page.

20
Frgure 8. Sketch map of Eldorado field, Kans., showing gas wells, location of samples, and helium content of gas...........

9. Curve showing decline of average rock pressure of a typical group of wells in the Eldorado field, Kans. . ...........

Page.

70

10. Sketch map of Augusta field, Kans., showing gas wells, location of samples, helium content of gas, and areas in which the shallow gas rich in helium occurs........................

11. Sketch map of Dexter-Otto area, Cowley County, Kans., showing location of wells sampled and helium content of

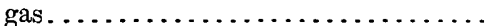

12. Detailed map of the town of Dexter, Kans., showing location of wells sampled and helium content of gas.....

13. Map of Sedan district, Kans., showing location of wells sampled and helium content of gas.

14. Diagram showing production of natural gas in Kansas and Oklahoma.

15. Map of Petrolia field, Tex., showing location of wells sampled and helium content of the gas.................

16. Curve showing average closed pressure and average open flow of gas wells of Lone Star Gas Co. in the Petrolia field, Tex
73 


\title{
HELIUM-BEARING NATURAL GAS.
}

\author{
By G. Sherburne Rogers.
}

INTRODUCTION.

\section{SCOPE OF THE INVESTIGATION.}

The gas helium, which was discovered on the earth by Sir William Ramsay in 1895 and which was at first regarded as one of the rare elements, was found in 1905 by H. P. Cady and D. F. McFarland to occur in small proportion in natural gas. from many localities in Kansas. The announcement of this discovery excited interest in scientific circles, but as no practical use for helium was known it had no industrial value, and efforts were not made to extract it except in very small quantities for experimental use. During the first year of the World War, however, a British scientist conceived the idea of using helium instead of hydrogen for inflating balloons, and in 1915 a vigorous but unsuccessful search for the gas in England was begun under the direction of Sir William Ramsay. This search was later extended to Canada but without attaining satisfactory results. On the entrance of the United States into the war the project was revived, and this Government undertook an energetic campaign for the production of helium in large quantities.

The value of helium for inflating balloons was brought to the attention of the Army and Navy by the Bureau of Mines, and that bureau was commissioned to investigate the practicability of extracting the gas in large quantities and at a reasonable cost. When the technologic feasibility of the project was assured, the Geological Survey was called upon to investigate the helium resources of the country, in order to locate the richest supplies of the gas and to form estimates of the quantity available. This paper is based on the results of that investigation and describes the distribution and geologic relations of heliumbearing natural gas, making only brief mention of the technologic problems involved in the extraction and purification of the helium.
As the Survey's investigation was made strictly for military purposes it was necessarily directed toward locating an adequate supply of helium-bearing gas as speedily as possible, and practically no attention was given to the broader scientific problems involved in the origin or ultimate source of the helium. Considerable research will evidently be necessary before this problem can be successfully attacked, and in view of the probable development of commercial aircraft during the coming decade, and the probability ' that the cost of extracting helium from natural gas will be reduced sufficiently to permit its use in commercial balloons, it has been deemed desirable to present immediately a brief description of the chief sources of helium in the United States. At the same time the writer has endeavored to describe the broader geologic relations of the helium-bearing gas, to discuss various theories of its origin, and to review the reported occurrences of helium in minerals and in other gases, in the hope that such a presentation of the problem will be of value to others who may later attempt to solve it.

VALUE OF HELTUM FOR INFLATING BALLOONS

The value of helium for inflating balloons, especially airships of the Zeppelin type, lies in its lightness and its incombustibility. Hydrogen, the gas commonly used for inflating balloons, is the lightest substance known, but mixed with air it is explosively combustible. For this reason a balloon filled with hydrogen is very liable to be set afire, either by atmospheric electricity, by sparks from its power plant, or by any one of numerous accidents which may occur even when it is in its hangar. The fire hazard is of course greatly increased in balloons used for military purposes, a single incendiary bullet being usually sufficient to destroy a great airship; and this weakness, inherent in all hydrogen-filled balloons, was 
not only a potent factor in the practical failure of the German Zeppelin program but has always been a serious drawback to the development of lighter-than-air craft. On the other hand, Assistant Secretary of the Navy Roosevelt is authority for the statement, "With the fire risk eliminated the rigid airship or Zeppelin will hence be one of the most powerful weapons known."

Helium weighs 0.0112 pound per cubic foot and is thus twice as heavy as hydrogen, which weighs only 0.0056 pound per cubic foot. In comparison with air, however, both gases are so light that this difference is of small practical importance, and the lifting power or buoyancy of helium is 93 per cent of that of hydrogen. The slightly greater weight of the helium is, moreover, far more than offset by its chemical inertness, for as helium does not combine with oxygen it can not explode or burn. Furthermore, its rate of diffusion is only about half that of hydrogen, and consequently it passes through the balloon fabric and wastes much more slowly. The chief advantage of helium, however, is obviously its incombustibility, for fire is one of the greatest of the hazards to which ordinary balloons are subject. Moreover, the use of a noninflammable gas permits modifications in the design of airships which make for greater speed and cruising radius, as well as for greater military efficiency. In view of these advantages; it is apparent that the use of helium for inflating airships, both military and commercial, will be limited solely by the supply of helium available and the expense at which it can be produced.

The painstaking and little-noticed research which led to Prof. Cady's discovery of helium in natural gas, and the conception of another scientist ten years later that balloons might be made far safer and more efficient if inflated with helium, furnish an inspiring example of the practical value which purely. scientific achievements may assume in course of time.

\section{DEVELOPMENT OF EXTRACTION PROCESSES.}

As the richest natural gas known contains only about 2 per cent of helium and the richest gas occurring in large quantity carries only 1 per cent, the development of a process for extracting and purifying the helium at a

1 Official Bull. U. S., Mar. 18, 1919, p. 9. reasonable cost is obviously of prime importance. The investigation of extraction processes was carried on by the Bureau of Mines and has been described elsewhere. ${ }^{2}$ Only a brief account will be given here.

It was recognized at the outset that the only practicable means of separating helium from the methane, ethane, nitrogen, etc., with which it is found, lay in taking advantage of the difference in boiling points of these elements-in other words, by employing a system of gas liquefaction and distillation such as is used to extract oxygen from the air. Of the common constituents of natural gas, butane, at atmospheric pressure, boils (that is, passes from the liquid to the gaseous state) at $1^{\circ} \mathrm{C}$., propane at $-45^{\circ} \mathrm{C}$, ethane at $-93^{\circ} \mathrm{C}$., methane at $-165^{\circ}$ C., and nitrogen at $-195^{\circ}$ C., whereas the boiling point of helium is about $-268^{\circ} \mathrm{C}$. Hence by cooling the natural . gas to about $-200^{\circ}$ C., it is possible under proper mechanical conditions to liquefy all the constituents except helium and thus obtain the helium as the gaseous residue. The remaining constituents, after being returned to their normal gaseous state, may be used as ordinary natural gas.

At the time the investigation started there were two well-established companies controlling respectively the Linde and Claude systems of gas liquefaction, and these companies were invited to cooperate in an effort to modify their apparatus-designed primarily for treating air-so as to treat the helium-bearing gas. Two plants, each designed to produce at atmospheric pressure about 7,000 cubic feet of helium a day, were erected at Fort Worth, Tex., in the spring of 1918 , to experiment on the gas of the Petrolia field, which carries 0.90 per cent of helium. Within six weeks after starting operations the Linde plant was producing a small volume of gas containing 50 per cent of helium, and about four months later it had attained an average production of 5,000 cubic feet a day of gas carrying more than 70 per cent of helium, which was further purified by a second process to a helium content of 93. per cent. The Claude plant also gradually increased the purity and the volume of its product, and although up to February 1, 1919 , its performance was materially behind

${ }^{2}$ Cottrell, F. G., Commercial production of helium: Chem. and Met. Eng., vol. 20, p. 104, February, 1919. Stewart, Andrew, Production of helium for use in airships: Bur. Mines Bull. 178C (excerpt), 1919. 
that of the Linde plant, further modifications in the apparatus were then being made which were expected to increase its efficiency greatly. At the time the armistice was signed, November 11, 1918, the first shipment from these plants, of 147,000 cubic feet of 93 per cent helium, or about enough to fill four ordinary kite balloons, was on the dock awaiting transportation to Europe.

The Linde and Claude processes differ considerably in principle. By the Linde process the gas is compressed to about 2,000 pounds to the square inch and cooled successively by water, liquefied carbon dioxide, and the liquefied gases obtained later as a by-product of the main operation. It is then allowed to expand through a regulating throttle and finally to escape from the apparatus at ordinary pressure. The very low temperature necessary to liquefy nitrogen is attained through the Joule-Thomson effect. Gas at a pressure of about 2,000 pounds is allowed to escape through a porous plug or valve to a lower pressure, whereby it is cooled. The gas thus cooled is used in turn to cool the compressed gas. On the frequent repetition of this procedure the temperature of the compressed gas ultimately falls below its boiling point. The apparatus has the merit of simplicity and freedom from moving parts, an important consideration under the low temperatures necessary; but the very high pressure under which the incoming gas must be pumped necessitates the installation of powerful compressors, which greatly increase the cost and operating expense of the plant as a whole.

The Claude process depends on an entirely different principle, a portion of the compressed and cooled gas being passed through an expansion engine and made to do work instead of merely expanding through a fixed throttle. In this way, with an initial pressure at the engine's intake of only about 400 pounds to the square inch and a very much lower pressure at its exhaust, a sufficiently low temperature is reached not only to fractionate by liquefaction the gas that has passed through the engine but also to fractionate by heat interchange another portion of compressed gas in the apparatus. The Claude process is thus more efficient thermodynamically than the Linde process and eliminates some of the compressors whose cost and power consumption contribute largely to the expense of the Linde plant. Another consideration is the fact that the natural gas in some fields is under a rock pressure of 400 or even 800 pounds to the square inch, so that in the Claude process it can be used without further compression, the expense of compressors being thus avoided.

About the time the helium investigation was undertaken a third process, known as the Jeffries-Norton process, was being perfected by its inventors. This process was regarded by Cottrell as theoretically more efficient than either of the older ones and capable of greatly reducing the expense of production. After an investigation of its merits by the National Research Council, the erection of a plant at Petrolia was begun, but the installation was not completed until shortly before the armistice was signed. Since that time the plant has been undergoing testing and adjustment, but on April 3, 1919, a test run yielded a product containing 20 per cent helium and it was expected that quantity production could soon be begun and that the cost would be far below that of either the Linde or the Claude process. The Jeffries-Norton process is somewhat similar to the Claude but differs in using three expansion engines instead of one. Each engine works through a different temperature range, acting on the gases after their liquefaction and distillation and permitting treatment of all the gas in this manner. The process is therefore theoretically more efficient than the Claude process and should attain the desired temperatures with an even lower initial pressure.

As judged by actual performance up to April 1, 1919, the Linde process, the most elaborate and expensive of the three, has given the best results, though further modification of the Claude process may render its operation on natural gas equally satisfactory. The Jeffries-Norton plant was just beginning to operate on a commercial basis, but it is believed that in view of the theoretical superiority of the process it will prove capable of producing helium far more cheaply than the older processes. At the time the investigation was begun it was thought that helium could not be produced from the Petrolia gas by the Linde or Claude processes for less than $\$ 100$ per thousand cubic feet, but with the erection of large plants it is now evident that this figure can be reduced to $\$ 60$ or $\$ 80$ per thousand 
cubic feet, and if the Jeffries-Norton process fulfills expectations the cost will be still lower.

As the cost of extraction depends on the volume of natural gas handled in the plant rather than on the volume of product, it is evident that the cost of treating a lower-grade gas is much greater than that of handling a gas like that of the Petrolia field, which carries 0.9 per cent of helium. Helium has been produced in the Fort Worth plants from mixtures of the Petrolia gas with that from other fields, the mixture carrying only 0.4 to 0.5 per cent of helium, but figures of cost are not available. Experiments have been made in other countries on gas carrying 0.25 to 0.3 per cent of helium, but the cost of extraction by the ordinary methods proved prohibitive. If the Jeffries-Norton process. finally proves successful, it should be possible to treat such gases, but by the older method the minimum workable helium content is probably somewhere near 0.5 per cent.

\section{ACKNOWLEDGMENTS.}

Although the investigation which the writer conducted for the Geological Survey dealt wholly with the distribution and geologic relations of the helium-bearing natural gas, it touched at several points the work of the Bureau of Mines investigators, whose cordial aid and cooperation the writer desires gratefully to acknowledge. Special mention should be made of the cooperation and advice of J. O. Lewis, then superintendent of the Bureau of Mines Experiment Station at Bartlesville, Okla., who furnished every facility at his command for the advancement of the work. The writer's thanks are also due to R. B. Moore, who was in charge of the gas experiment plants at Fort Worth and under whose general direction much of the analytical work was done; to A. W. Ambrose and E. W. Wagy, who collected about 70 samples of gas in the Northwestern States and California; and to C. F. Ward, who, under the direction of P.M. Biddeson, collected a number of samples in different parts of the country.

An important part of the data on which this report is based consists of the chemical information-chiefly determinations of the helium content of natural gas samples-furnished by the Bureau of Mines. When the helium investigation was first started the analytical work was performed under the direction of Prof. H. P. Cady, of the University of Kansas, the methods followed being essentially those used by Cady and McFarland in their earlier research. Most of the samples discussed in this report, including all those collected by Survey members, were examined by Mr. C. W. Seibel, chemist at the Fort Worth experiment plant and a former pupil of Prof. Cady, and the writer desires to record his appreciation of the prompt and painstaking manner in which $\mathrm{Mr}$. Seibel performed this work. Mr. Seibel has also furnished an account of the analytical methods employed, which is given on pages 41-42.

As helium occurs characteristically in gases high in nitrogen, an ordinary analysis of a gas may furnish a clue as to its probable helium content. The writer's thanks are due to Prof. H: C. Allen, of the University of Kansas, who generously contributed numerous analyses of the gases of Kansas and northern Oklahoma.

The field work on which this report is based was done between June 5 and November 10 , 1918. The writer was efficiently assisted in his studies in the Mid-Continent and Texas fields by P. V. Roundy, C. E. Dobbin, R. G. Argabrite, and C. R. Bickel. George B. Richardson investigated the helium resources of the Vinton County district, Ohio, and a brief summary of his report is incorporated in this paper. C. E. Van Orstrand's valuable aid in making some of the computations here given is gratefully acknowledged. The whole investigation was conducted under the general direction of David White, who, by suggestion and advice, contributed materially to its success.

Valuable aid was rendered by many oil and gas operators and by the geologists and other officials of the larger operating companies, many of whom patriotically sacrificed time and money to assist in the work. Special mention should be made of the contribution of C. A. Fisher, consulting geologist, of Denver, Colo., who undertook the collection of a complete suite of samples from all the Wyoming fields. Acknowledgments are also due to Arthur Denman, of Sedan, Kans.; to William Kennedy and others, of the Lone Star Gas Co., Fort Worth, Tex.; to Everett Carpenter, J. B. McCune, A. W. McCoy, G. B. McKinley, and others, of the Empire Gas \& Fuel Co., Bartlesville, Okla.; to C. R. Burke, of the Oklahoma Natural Gas Co., Tulsa, Okla.; and to a great 
many others. The Empire Gas \& Fuel Co., the Carter Oil Co., the Roxana Petroleum Co., the Texas Co., the Lone Star Gas Co., and the Devonian Oil Co. furnished considerable geologic information, including structural maps of many areas.

\section{FIELD INVESTIGATION}

The field work on which the investigation of helium in natural gas was based consisted chiefly of collecting samples of gas for analysis and in gathering data regarding the depth, geologic position, rock pressure, and volume of the gas sampled. If the sample proved rich enough in helium to be of value investigations of the quantity of gas available and of the probable duration of the supply were made. This work involved careful examination of the structural geology in one or two areas, though a number of the helium-rich districts had been previously examined by Survey geologists in connection with other investigations, and data on many others were generously furnished by oil companies.

Most of the gas samples were collected under pressure in steel containers which consisted of about 10 inches of $1 \frac{3}{4}$-inch seamless tubing with a 1 -inch nipple welded in each end. Special needle valves were set in the nipples and protected by short extra lengths of tubing welded on each end of the container, so as to form a single tube about 18 inches long, strong enough to withstand transportation by mail without extra wrapping. The containers were coupled directly to the well with both needle valves open, and the gas was allowed to blow through for a minute or so in order to expel the air. The samples were taken at full rock pressure, provided this did not exceed 100 to 200 pounds to the square inch, though at a pressure of only 50 pounds sufficient gas enters the tubes to afford a satisfactory determination of the helium content. A few low-pressure samples were collected in half-gallon'glass bottles, fitted with porcelain and rubber pressure stoppers, the gas being allowed to blow into the inverted bottle for a period of 5 to 10 minutes.

The samples were forwarded immediately to the Bureau of Mines laboratory at Fort Worth, Tex., and were analyzed promptly. A description of the analytical methods employed is given on pages $41-42$.

\section{DISCOVERY OF HELIUM.}

Peculiar interest attaches to the element helium by reason of the fact that it was discovered in the sun almost 30 years before it was found on the earth. In 1868 an eclipse of the sun was visible in India, and the spectroscope was then used for the first time to study the chromosphere, the colored atmosphere which envelops the sun. Lockyer ${ }^{3}$ recognized many of the common terrestrial elements in the solar chromosphere, but he also called attention to a brilliant yellow line in the spectrum which, though apparently associated with the $\mathrm{D}$ lines of sodium, did not exactly correspond with them. Lockyer, Frankland, and Janssen investigated this line further and, finding that it could not be ascribed to any known element, distinguished the line as $\mathrm{D}_{3}$ and suggested that the element represented by the line be called helium, a name derived from the Greek word for the sun.

In 1888 W. F. Hillebrand, ${ }^{4}$ of the United States Geological Survey, in the course of an analytical study of uraninite, found that this mineral when boiled with dilute sulphuric acid gave off considerable quantities of an inert gas. Hillebrand proved that this gas was in part nitrogen, and as no other inert gases were known at that time he concluded that it was all nitrogen. In 1892 Rayleigh and Ramsay ${ }^{5}$ discovered in the atmosphere a new inert gaseous element which they named argon, and in 1895 Ramsay, ${ }^{6}$ noting Hillebrand's results and believing that the gas evolved by uraninite might contain argon, undertook to examine it further. Ramsay, who used the mineral cleveite, a variety of uraninite, extracted the gas by Hillebrand's method and after removing oxygen and nitrogen examined the residue spectroscopically and at once recognized the bright yellow line $\mathrm{D}_{3}$, which Lockyer, Janssen, and Frankland had long before established as

${ }^{3}$ Lockyer, J. N., Spectroscopic observations of the sun: Philos. Trans., vol. 159, p. 428,1869

4 Hillebrand, W. F., On the occurrence of nitrogen in uraninite and on the composition of uraninite in general: U.S. Geol. Survey Bull. 78, p. 43,1891 .

- Rayleigh, Lord, and Ramsay, William, Argon, a new constituent of the atmosphere (abstract): Roy. Soc. London Prus., vol. 57, p. 265, 1892

${ }^{6}$ Ramsay, William, Discovery of hellum: Chem. News, vol. 71, p. 151, 1895; On a gas showing the spectrum of helium, the reputed cause of $D_{3}$ one of the lines of the coronal spectrum: Roy. Soc. London Proc., vol. 58, pp. $65,81,1895$. 
the distinctive line of their solar element, helium. Ramsay ${ }^{7}$ at once investigated other uranium-bearing minerals and found that fergusonite, bröggerite, yttrotantalite, pitchblende, and polycrase, as well as certain rareearth minerals, such as monazite, orangeite, and xenotime, yield helium in varying quantities. Kayser, ${ }^{8}$ a few months later, announced the presence of helium in the atmosphere and also in the gas emitted from the mineral springs of Wildbad, in the Black Forest. Subsequent work by various investigators has shown that helium is a minor constituent of many minerals and rocks and that it occurs in small proportions in some mine gases and in the gases of many mineral springs and fumaroles. (See pp. 43-52.) •

Although helium was thus found, very shortly after its discovery, to be widely distributed through the earth's crust, it was supposed to occur only in minute quantities and was regarded as one of the rare elements. It remained for Cady and McFarland to discover the great supplies of helium which are contained in natural gas. In 1903 a natural gas was found at a depth of about 400 feet at Dexter, Kans., which was so low in heat value that it was at first thought to be incombustible. A sample of this gas was submitted to the University of Kansas for analysis and was found. to contain about 15. per cent of methane and ethane and about 85 per cent of an inert gas, apparently nitrogen. ${ }^{\ominus}$ Further examination of this inert residue by Cady and McFarland proved it to contain 1.84 per cent of helium, with minute proportions of neon and argon..$^{10}$ An examination of natural gases from numerous localities in Kansas and elsewhere was then undertaken, and all but one of the samples examined were found to contain at least a trace of helium, though by far the largest proportions were found in gases of southern Kansas.

Cady and McFarland made their investigation chiefly from the chemist's point of view, and the quantitative aspect of their discovery

7 Ramsay, William, Collie, J. N., and Travers, Morris, Helium, a constituent of certain minerals: Chem. Soc. Jour., vol. 67, p. 684, 1895.

8 Kayser, H., Note on helium and argon: Chem. News, vol. 72, p. 89, 1895 .

9. Haworth, Erasmus, and McFarland, D. F., The Dexter, Kans., nitrogen gas well: Science, new ser., vol. 21, p. 191, 1904.

$10 \mathrm{Cady}$, H. P., and McFarland, D. F., The occurrence of helium in natural gas and the composition of natural gas: Am. Chem. Soc. Jour., vol. 29, p. 1524, 1907; The composition of natural gas, with special study of the constituents of Kansas gases: Kansas Univ. Geol. Survey, vol. 9, pp. 228-302, 1908. was not generally realized. The fact that the helium-bearing natural gas is produced at the rate of millions of cubic feet a day and that a helium content of only 1 per cent may thus mean the production of very large volumes of helium was passed unnoticed by foreign investigators, who, as late as 1912 , referred to springs producing 1,200 cubic feet of helium a year as the most prolific sources of the element known. ${ }^{11}$ Apparently it remained for the stimulus of the war emergency to bring recognition of the facts that enormous volumes of this supposedly rare element are being produced and wasted daily in the United States, and that if means could be found to extract the helium it would furnish an ideal gas for inflating balloons.

\section{NATURE OF HELIUM. PROPERTIES OF HELTUM.}

Helium is a colorless and odorless gas, having an atomic and molecular weight of 4 . Its two most distinctive properties are lightness and chemical inertness. Helium is the second lightest substance known; its density, compared with air as unity, is 0.1368 , whereas that of hydrogen is 0.0696 . Helium weighs 0.0112 pound per cubic foot and hydrogen 0.0056 pound, but the buoyancy of helium in air is about 93 per cent that of hydrogen. The boiling point of helium is so low that for many years all attempts to liquefy it failed, but in 1908 Onnes ${ }^{12}$ succeeded in liquefying helium at $4.5^{\circ}$ above absolute zero (about $-268.5^{\circ} \mathrm{C}$.) and found its density in the liquid form to be 0.122 .

Helium is an inert gas, showing no tendency to combine with other elements under any temperatures and pressures that can be produced in the laboratory. It is only slightly soluble in water, 100 volumes of water at $20^{\circ} \mathrm{C}$. dissolving 1.4 volumes of helium, and it is insoluble in absolute alcohol and benzene. After helium has been driven out of a mineral like uraninite it is not easily reabsorbed, though, according to Piutti, ${ }^{13}$ certain fused solids and minerals do absorb helium at moderate temperatures. Moreover, Jaquerod and Perrot ${ }^{14}$ have ob-

"Moureu, Charles, and Lepape, A., Sur quelques mélanges gazeux naturels particulièrement riches en hélium; Gisements d'hélium: Compt. Rend., vol. 155, p. 197, 1912.

12 Onnes, H. K., L'hélium liquide: Compt. Rend., vol. 147, p. 421, 1908.

13 Piutti, Arnaldo, Absorption of helium by rocks and minerals [abstract]: Chem. Soc. Jour., vol. 100, pt. 2, p. S8, 1911.

14 Jaquerod, A., and Perrot, F. L., Sur l'emploi de l'helium comme substance thermométrique et sur sa diffusion a travers la silice: Compt. Rend., vol. 139 ,p. $789,1904$. 
served that helium diffuses through quartz, the diffusion becoming noticeable at $220^{\circ} \mathrm{C}$. and rapid at $1,100^{\circ} \mathrm{C}$. These observations are important geologically, as will be shown below (p. 47).

Helium is readily identified by the spectroscope, its spectrum being very brilliant. The characteristic and exceptionally brilliant yellow line, $\mathrm{D}_{3}$, by which helium was originally discovered in the sun, is not masked by any other element. This line has a wave length of 587.6 millionths of a millimeter $(5,876$ Ångström units). ${ }^{15}$ In addition helium shows two red lines, one of which is brilliant, and a green, a blue, and a violet line, as well as several fainter lines.

RELATION OF HELIOM TO THE RADIO-ELEMENTS. DISCOVERY OF RADIUM.

Although in a strictly chemical sense helium is an inert element, it is genetically involved in the process of radioactivity, and in order to consider intelligently the origin and distribution of helium it is necessary to understand clearly its relation with the so-called radioelements. ${ }^{16}$

The property of radioactivity was discovered in 1.596 by Becquerel, in the course of his experiments on fluorescence. $\mathrm{He}$ found, partly by accident, that salts of uranium would, without previous exposure to the sunlight, affect a photographic plate. Madame Curie, becoming interested in his results, tested other elements and found that both uranium and thorium exhibit the same property. By experimenting with various compounds she found, moreover, that a given weight of uranium or thorium possesses the same degree of activity, regardless of whether it is combined as sulphate, chloride, or bromide-in other words, that radioactivity is an atomic property. In experimenting with the minerals in which uranium and thorium occur, however, she found that pitchblende, carrying a given weight of uranium, is several times as radioactive as an equivalent quantity of a pure uranium salt,

16 Crookes, William, The spectrum of the gas from cleveite: Chem. Nows, vol. 71, p. 151,1895 ; Tho spectrum of helium: Idem, vol. 72, p. 87,1895 .

10 For summarics of our knowledge of radium and the property of radioactivity, see Rutherford, E., Radioactive transformations, . New York, 1900; Radioactive substances and their radiations, Cambridge, 1913; Soddy, Froderick, The interpretation of radium, New York, 1912. A recent conciso summary is given by $R$. B. Moore (Radium: $A$ m. Inst. Min. Eng. Bull. 140, p. 1165, Augrust, 1918). indicating that some unknown element more active than uranium itself exists in the mineral. On carefully separating the metals that occur in this complex mineral she found that several groups are active but that the most active of all is the alkaline-earth group. Upon further investigation of this group she discovered as the cause of its activity the new element radium. Subsequent work by Madame Curie and other investigators, prominent among whom were Rutherford, Ramsay, and Soddy, have brought to light the existence of not only one but almost 30 new unstable bodies, the study of whose transformations has opened an entirely new field in physics and chemistry. A historical review of these discoveries would be out of place here, but a brief account of the radioactive processes into which these ephemeral substances enter is given in the following paragraphs.

\section{THEORY OF RADIOACTIVITY.}

One of the first observations made on radium showed that it is continuously losing energy at a remarkable rate, having, in fact, the power of raising the temperature of 133 times its own weight of water by $1^{\circ} \mathrm{C}$. an hour. Moreover, in addition to the properties of fluorescence and of affecting the photographic plate, it was found that radium has the faculty of producing charged carriers of electricity, or ions, in the gases surrounding it, in this manner rendering the gases conductors of electricity. It was soon recognized that all these effects are due to actual radiations or emanations given off by radium -in other words, that the radium atom is actually undergoing spontaneous disintegration into other atoms.

Studies of the emanation given off by radium indicated it to be a heavy gas, radioactive in character but totally different in its other properties from the parent radium; and it was found, moreover, that the activity of the emanation decreases at a constant rate and always reaches half of its original value in 3.8 days. Further study led to the discovery that the decrease in activity of the emanation is due to its own disintegration, and that it forms a solid body which is also radioactive and which in turn is rapidly transformed into another active product. These facts led Rutherford and Soddy in 1902 to enunciate their disintegration theory - "that the atoms of radioactive bodies 
are unstable and that a certain fixed proportion of them become unstable every second and break up with explosive violence, accompanied in general by the expulsion of particles."

THE URANIUM-LEAD RADIOACTIVE SERIES.

In the light of the disintegration theory it became possible to explain the constant association of uranium, radium, helium, and lead in pitchblende and other minerals. Uranium has an atomic weight of 238 , which is higher than that of any other element; radium has an atomic weight of 226 , radium emanation of 222 , lead of 207, and helium of 4 . It was suggested by Rutherford and Soddy that the transformation of radium into radium emanation might be accompanied by the expulsion of helium atoms, causing the decrease in atomic weight from 226 to 222, and a year later Ramsay and Soddy actually showed that radium salts give off helium, thus proving for the first time the derivation of one element from another. ${ }^{17}$

By the same line of reasoning it was supposed that uranium might be the parent of radium, and, as the difference in their atomic weights is 12 , that radium must represent the third step in the disintegration of uranium, each stage of which must result in the formation of one helium atom. Subsequent investigations by Boltwood and others established che existence of these intermediate products and thus definitely proved the derivation of radium from uranium. At the other end of the series several intermediate products having itomic weights lower than that of radium were found, and the hypothesis was advanced that the ultimate disintegration product is lead. The objection to this hypothesis was the fact that the atomic weight of ordinary lead is 207, whereas the expulsion of 5 helium atoms from radium should result in $226-(5 \times 4)=206$. This objection has recently been removed by the discovery of an isotopic form of lead having an atomic weight of $206,{ }^{18}$ and all the main steps in the disintegration of uranium through radium and various other products to lead are now well established. As the difference in atomic weight between uranium (238) and lead (206) is 32,8 helium atoms are given off

${ }_{17}$ Ramsay, William, and Soddy, Frederick, Experiments in radioactivity, and the production of helium from radium: Roy. Soc. London Proc., vol. 72, p. 204, 1903.

18 Richards, T. W., The problem of radioactive lead: Science, new ser., vol. 49, p. 1,1919 . in the course of the disintegration, and uranium may provisionally be considered the compound $\mathrm{PbHe}_{8}$. '(See p. 53.)

Careful investigations by Rutherford and others of the nature of the rays emitted by the radioactive substances in the course of their disintegration have revealed the fact that the rays are of three kinds. The alpha rays are the most important, being in fact the helium atoms themselves. They are expelled at a velocity of about 20,000 miles a second and are the chief cause of the heating effects of radioactivity. The beta particles are electrons having a much smaller mass than the alpha particles but a greater velocity and penetrating power. The gamma rays are not material in character but are simply vibrations in the ether. Some of the radio-elements in their transformation emit all three types of rays, and others give off only one; but it is only when the alpha rays are given off that a decrease in atomic weight, with the formation of helium, takes place.

Each radioactive substance breaks down at a definite and characteristic rate, the disintegration of uranium, for example, being extremely slow,. whereas that of radium emanation is rapid. The number of atoms disintegrating each second, however, is invariably proportional to the total number present, so that as the quantity of the decaying substance decreases the rate of formation of the new body diminishes correspondingly. For example, half a given quantity of radium disintegrates in 1,690 years, half of the remainder in 1,690 years more, and so on; hence, at the end of 16,900 years only about 0.1 per cent of the original mass will be left. In order to avoid the consideration of infinitesimal quantities, it is convenient to express the rate of decay in terms of the "half-life period"-the period in which half of a given quantity disintegrates. The following table shows the order and rate of disintegration of the uranium-lead series:

The uranium-lead radioactive series.

\begin{tabular}{|c|c|c|c|}
\hline & $\begin{array}{c}\text { Atomic } \\
\text { weight. }\end{array}$ & Rays. & Half-life period. \\
\hline Uranium $1 \ldots$ & 238 & Alpha... & $5.3 \times 10^{9}$ years. \\
\hline Uranium $\mathrm{X}_{1} \ldots$ & 234 & Beta ......... & 24 days. \\
\hline Uranium $\mathrm{X}_{2} \ldots$ & 234 & $\begin{array}{l}\text { Beta and gam- } \\
\text { ma. }\end{array}$ & 1.15 min. \\
\hline Uranium $2 \ldots$ & 234 & Alpha........ & $2 \times 10^{6}$ years. \\
\hline Ionium....... & 230 & $\ldots$ do & $10^{5}$ years? \\
\hline
\end{tabular}


The uranium-lead radioactive series-Continued.

\begin{tabular}{|c|c|c|c|}
\hline & $\begin{array}{l}\text { Atomic } \\
\text { weignt. }\end{array}$ & Rays. & Half-life period. \\
\hline Radium... & 226 & Alpha and slow & 1,690 years. \\
\hline $\begin{array}{l}\text { Radium ema- } \\
\text { nation. }\end{array}$ & 222 & Alpha... & 3.8 days. \\
\hline Radium A..... & 218 & $\ldots$ do $\ldots \ldots$. & $3.0 \mathrm{~min}$. \\
\hline Radium B..... & 214 & $\begin{array}{l}\text { Beta and gam- } \\
\text { ma. }\end{array}$ & $27 \mathrm{~min}$. \\
\hline Radium C.... & 214 & Alpha, beta, and & $19.5 \mathrm{~min}$. \\
\hline Radium D.... & 210 & $\begin{array}{l}\text { Beta and gam- } \\
\text { ma. }\end{array}$ & 16.5 years. \\
\hline Radium E..... & 210 & Beta.......... & 5.0 days. \\
\hline $\begin{array}{l}\text { Radium If (po- } \\
\text { lonium). }\end{array}$ & 210 & Alpha... & 136 days. \\
\hline Radium G(lead) & 206 & & \\
\hline
\end{tabular}

As the disintegration of each substance in the series proceeds according to a definite law, which is unchanged by any external conditions; it follows that the quantity of any member of the series in existence at a given moment is related to the existing quantity of the first member, uranium. Each member is continually breaking down but is as constantly being replenished, so that each is in equilibrium with the others. The quantities of the uranium products in equilibrium with 1 kilogram of uranium are given by Rutherford ${ }^{19}$ as follows: Uranium 2, 196 milligram (?); ionium, 39 milligrams (?); radium, 0.34 milligrams. The quantities (in grams) of the radium products in equilibrium with 1 gram of radium are:

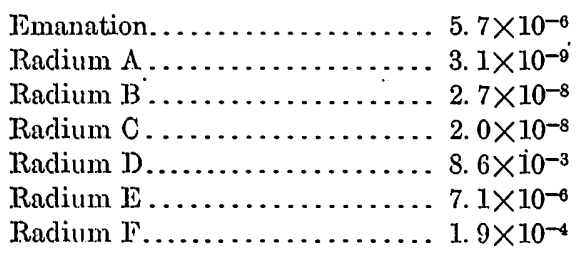

Thus, for example, 1 kilogram of uranium in the earth is invariably associated with 0.34 milligram of radium, and similarly the presence of a certain amount of emanation and the succeeding products indicates the presence of a certain definite amount of radium. The ordinary method of determining small quantities of radium in rocks or minerals is an important practical application of this principle. The principle is important also in a study of the origin of helium, for if the helium in natural gas is solely a product of radioactivity, its

10 Rutherford, E., Radioactive substances and their radiations, pp. 468, 518, Cambridge; 1913. volume should bear a definite relation to those of the radio-elements.

THE THORIOM-IEAD RADIOACTIVE SERIES.

The foregoing account has, for the purpose of clarity, been confined to the uranium-lead series, but all the principles discussed apply equally well to another radioactive series, the first member of which is thorium and the last another isotopic form of lead. Thorium, like uranium, has a half-life period measured in billions of years, and the succeeding products are very short-lived. Thorium $\mathrm{X}$ and thorium emanation are analogous to radium and radium emanation, and the next lower bodies resemble the corresponding ones in the uranium series. The thorium series involves a total loss of 24 in atomic weight, indicating the formation of 6 helium atoms. The sequence of the thoriumlead series is shown in the following table:

The thorium-lead radioactive series.

\begin{tabular}{|c|c|c|c|}
\hline & $\begin{array}{l}\text { Atomic } \\
\text { weight. }\end{array}$ & Rays. & Half-1ife period. \\
\hline Thorium...... & 232 & Alpha.. & 1. $8 \times 10^{10}$ years. \\
\hline Mesothorium 1 . & 228 & Beta.......... & 5.5 years. \\
\hline Mesothorium 2 . & 228 & $\begin{array}{l}\text { Beta and gam- } \\
\text { ma. }\end{array}$ & 6.2 hours. \\
\hline Radiothorium. . & 228 & Alpha.......... & 2 years. \\
\hline Thorium X.... & 224 & ....do.......... & 3.65 days. \\
\hline $\begin{array}{l}\text { Thorium ema- } \\
\text { nation. }\end{array}$ & 220 & .... do.......... & 54 sec. \\
\hline Thorium A.... & 216 & .....do. & $0.14 \mathrm{sec}$. \\
\hline Thorium B.... & 212 & $\begin{array}{l}\text { Beta and gam- } \\
\text { ma. }\end{array}$ & 10.6 hours. \\
\hline Thorium C..... & -21.2 & Alpha and beta. & $60 \mathrm{~min}$. \\
\hline Thorium $\mathrm{D}_{1} \ldots$ & 208 & Beta and gam- & $3.1 \mathrm{~min}$. \\
\hline 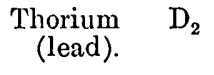 & 208 & & \\
\hline
\end{tabular}

OTHER RADIOACTIVE SERIES.

Actinium, the first member of a radioactive series analogous to those already described, was discovered by Debierne in 1899, and seven lower members of the series. have since been identified. It has not yet been possible to determine the atomic weight of actinium, however, and the relation of the series is not clear, though actinium occurs in association with uranium, and the series is generally believed to be a branch of the uranium-lead series. The decay of actinium, which, according to Debierne, results in the formation of helium, ${ }^{20}$ is exceed-

20 Debierne, A., Expériences sur la production de l'hélium par les substances radioactives: Annales phys., vol. 2, pp. 428-488, 1914. 
ingly slow, but the half-life periods of the succeeding products are very rapid, being measured in seconds or minutes.

In addition to the elements of the uranium, thorium, and actinium series, which are comparable in regard to strength of radioactivity, there are apparently certain much more faintly radioactive elements. Thus the researches of Campbell and Wood ${ }^{21}$ indicate that certain of the alkali metals, notably potassium and rubidium, are faintly radioactive. Although the activity of potassium, as measured by its ionizing power, is only about one onethousandth that of uranium, the fact that potassium is thousands of times as abundant as uranium in the earth's crust lends its activity a. special significance geochemically. On the other hand, the rays given off by potassium appear to be beta rays ${ }^{22}$ or electrons, and there is yet no experimental basis for supposing that the decay of potassium results in the expulsion of alpha rays and the formation of helium. For the purposes of this paper, therefore, the possible relation of potassium and rubidium to the formation of helium need not be considered further.

RATE OF PRODUCTION OF HELIOM BY THE RADIOELEMENTS.

As the disintegration of each radioactive substance proceeds at a definite rate, it is evident that any such substance will yield a definite and $\operatorname{radium} \mathrm{A}, \mathrm{B}$, and $\mathrm{C}-$ is $13.6 \times 10^{10}$; and as there are $2.78 \times 10^{19}$ atoms of helium in 1 cubic centimeter at standard pressure and temperature it can be calculated that the rate of production of helium per gram of radium is 158 cubic millimeters a year. Actual measurements by Rutherford and Boltwood indicated a rate of 164 cubic millimeters, which is well within the limits of experimental error.

The rate of production of helium by uranium and thorium in equilibrium with their products is shown in the following table: ${ }^{23}$

\begin{tabular}{|c|c|c}
\multicolumn{2}{|c}{ Rate of production of helium. } \\
\hline Radioactive substance. \\
. & $\begin{array}{c}\text { Total number of } \\
\text { alpha particles per } \\
\text { gram per second. }\end{array}$ & $\begin{array}{c}\text { Helium produced } \\
\text { per gramic per year } \\
\text { (cubic milli- } \\
\text { meters). }\end{array}$ \\
\hline $\begin{array}{c}\text { Uranium................. } \\
\text { wranium in equilibrium all its products.. } \\
\text { Thorium in equilibrium } \\
\text { with all its products.. } \\
\text { Radium in equilibrium } \\
\text { with emanation, ra- } \\
\text { dium A, and radium C. }\end{array}$ & $2.37 \times 10^{4}$ & $2.75 \times 10^{-5}$ \\
\hline
\end{tabular}

Experimental confirmation of these calculations has been furnished by Strutt, ${ }^{24}$ who carefully measured the quantity of helium produced by thorianite and pitchblende, ancient minerals in which complete equilibrium had long been established. Strutt's results are as. follows:

Rate of production of helium from thorianite and pitchblende.

\begin{tabular}{|c|c|c|c|c|}
\hline \multirow{2}{*}{. } & \multirow{2}{*}{$\begin{array}{l}\mathrm{U}_{3} \mathrm{O}_{8} \text { (per } \\
\text { cent). }\end{array}$} & \multirow{2}{*}{$\begin{array}{l}\mathrm{ThO}_{2}(\dot{\mathrm{per}} \\
\text { cent). }\end{array}$} & \multicolumn{2}{|c|}{$\begin{array}{l}\text { Helium produced per gram per year } \\
\text { (cubic millimeters). }\end{array}$} \\
\hline & & & Observed. & Calculated. \\
\hline 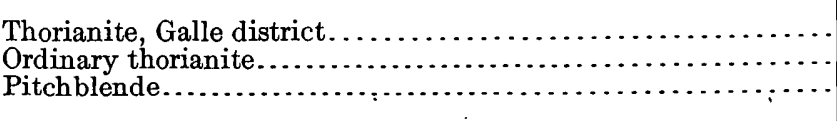 & $\begin{array}{l}24.50 \\
13.10 \\
37.6\end{array}$ & $\begin{array}{l}65.44 \\
72.65 \\
\text { None. }\end{array}$ & $\begin{array}{l}3.70 \times 10^{-5} \\
2.79 \times 10^{-5} \\
3.16 \times 10^{-5}\end{array}$ & $\begin{array}{l}4.1 \times 10^{-5} \\
3.2 \times 10^{-5} \\
3.5 \times 10^{-5}\end{array}$ \\
\hline
\end{tabular}

quantity of helium in a given time; and as each substance is in equilibrium with all the others, it follows that the amount of helium produced in a given time by the whole series is also a fixed quantity. Rutherford has shown that the number of alpha particles expelled per second from a gram of radium in equilibrium with its immediate descendants-emanation

${ }^{21}$ Campbell, Norman, and Wood, Alexander, The radioactivity of the alkali metals: Cambridge Philos. Soc. Proc., vol. 14, pt. 1, p. 15, 1907.

${ }_{22}$ Campbell, Norman, The beta rays from potassium: Cambridge

Philos. Soc. Proc., vol. 14, pt. 2, p. 211, 1907.
The agreement between the observed and calculated results is sufficiently close to confirm the validity of the principles on which the calculations were based. With these data it is obviously possible to calculate the amount of helium being produced in nature under normal conditions each year. (See pp. 59-60.)

23 Rutherford, E., Radioactive substances and their radiations, p. 560, Cambridge, 1913.

24 Strutt, R. J., Measurements of the rate at which helium is produced in thorianite and pitchblende, with a minimum estimate of their antiquity: Roy. Soc. London Proc., ser. A, vol..84 ,p. 379, 1910. 


\section{ASSOCIATION OF HELIUM WITH THE RARE GASES.}

Helium usually occurs in nature associated with a group of inert gaseous elements commonly referred to as the rare gases of the atmosphere. ${ }^{25}$ The first of these gases to be discovered was argon, so named because of its chemical inertness. In 1892 Rayleigh observed that the nitrogen of the atmosphere is slightly heavier than nitrogen prepared in the laboratory, and an investigation of this discrepancy by Rayleigh and Ramsay led to the discovery, two years later, of the new element argon. As already described, it was Ramsay's search for the occurrence of argon in minerals that led him to the discovery of helium. The inertness of both these gases, as well as correspondence in other properties, indicated that they belong to the same family, and by deductions drawn from the periodic classification of the elements Ramsay was led to predict that three other similar gases remained to be discovered. After fruitless search for these elements in minerals and in sea water, Ramsay and Travers finally discovered them in the atmosphere, a year after the prediction was made.

Particulars regarding the group of rare gases are given in the following table: nation is dissolved in water, and argon when it is dissolved in a solution of copper salts; but this is denied by Debierne, ${ }^{27}$ who used methods more refined than Ramsay's, and the theory has not been generally accepted.

The association of helium with the rare gases appears to be more reasonably explained by the work of Moureu and Lepape, who have investigated the occurrence of these elements in the gases of many mineral springs and in mine gases. They find that all these elements occur in every gas examined and that the relative proportions of all of them except helium are always nearly constant and closely approximate their proportions in the atmosphere. This is accounted for by Moureu and Lepape on the grounds that (1) the gases are chemically inert and (2) they retain their gaseous state, in which they are perfectly miscible, under wide variations of temperature and pressure. As no chemical forces operate to add or subtract any one of them from a gaseous mixture, and as physical forces such as diffusion and occlusion have only a minor influence, it is to be expected that in the atmosphere and in all other natural gases these elements will occur in essentially the same mutual proportionsproportions which, according to the authors

Properties of the rare gases and their proportion in the atmosphere.

\begin{tabular}{|c|c|c|c|c|c|}
\hline & Symbol. & $\begin{array}{l}\text { Atomic } \\
\text { weight. }\end{array}$ & $\begin{array}{l}\text { Density } \\
\text { (air=1). }\end{array}$ & $\begin{array}{l}\text { Boiling point } \\
\left({ }^{\circ} \mathrm{C} .\right) \text {. }\end{array}$ & $\begin{array}{l}\text { Per cent by } \\
\text { volume in the } \\
\text { atmosphere. }\end{array}$ \\
\hline 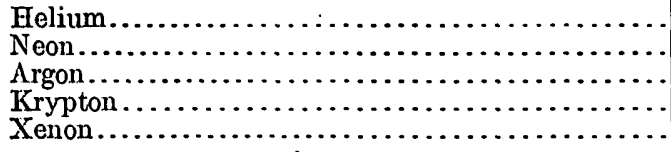 & $\begin{array}{l}\mathrm{He} \\
\mathrm{Ne} \\
\mathrm{A} \\
\mathrm{Kr} \\
\mathrm{Xe}\end{array}$ & $\begin{array}{l}4.00 \\
20.2 \\
39.9 \\
82.92 \\
130.2\end{array}$ & $\begin{array}{l}0.1368 \\
.6963 \\
1.379 \\
2.868 \\
4.526\end{array}$ & $\begin{array}{l}-268.5 \\
-239.0 \\
-186.1 \\
-151.7 \\
-109.1\end{array}$ & $\begin{array}{l}0.0004 \\
.00123 \\
.937 \\
.028 \\
.005\end{array}$ \\
\hline
\end{tabular}

The group relationship of these gases is shown by their regularly increasing atomic weights and densities and by their decreasing boiling points. It is confirmed by the fact that they all exhibit chemical inactivity, showing no tendency to combine with other elements (except, indeed, in so far as uranium may be regarded as a combination of helium and lead). Ramsay ${ }^{26}$ has sought to show that neon and argon also originate through the decay of radium emanation, neon when the ema-

20 Seo Ramsay, William, The gases of the atmosphere, London, 1915

26 Camoron, $\Lambda$. T.; and Ramsay, William, The chemical action of radium omanation: Chem. Soc. Jour., vol. 91, pp. 1593-1606, 1907. cited, must be those in which the elements occurred in the primordial nebula from which the earth sprang. This last conclusion seems a bit overdrawn, for the authors apparently do not take into account the difference in the solubility of the gases in natural waters, which might result in altering their proportions considerably. The great irregularity in the proportions of helium, however, is easy to explain by reason of the constant formation of helium through the decay of the radio-elements. On the other hand, as helium is also inert, in the

27 Debierne, A., Expériences sur la production de l'hélium par les substances radioactives: Annales phys., vol. 2, p. 433, 1914 
sense that it can not be removed from a mixture by combination with other elements, and as it is constantly being generated in the earth, it follows that all subterranean gaseous mixtures should contain a larger proportion of helium than the atmosphere.

The following table shows the ratios of argon to nitrogen, of krypton to argon, of xenon to argon, and of xenon to krypton in a number of gases, as compared with their ratios in the atmosphere. It will be noted that all of these ratios approximate unity, which represents the corresponding value in the atmosphere. So far as the writer knows, the only investi- gation yet made that conflicts with these results is Ramsay's discovery of 0.24 part of neon per 100 parts of nitrogen in the gases emitted by the Bath Mineral Springs, England, the ratio of neon to nitrogen in this case being about 244 times as high as it is in the atmosphere. ${ }^{28}$ Moureu and Lepape unfortunately did not determine neon quantitatively, though they ascertained its presence in all the gases which they examined..$^{29}$

28. Ramsay, William, Report on the mineral waters of Bath: Chem. News, vol. 105, p. 133, 1912.

${ }^{29} \mathrm{Moureu}$, Charles, and Biquard, R., Sur la présence du néon parmi les gaz de quelques sources thermales: Compt. Rend., vol. 143, p. 180, 1906.

Ratios of the rare gases in the gases of mineral springs and in gas from Vesuvius, as compared with their ratios in the atmosphere. $a$

\begin{tabular}{|c|c|c|c|c|}
\hline Source of gas. & $\frac{A / N_{2} \text { gas }}{A / N_{2} \text { air }}$ & $\frac{\mathrm{Kr} / \mathrm{A} \text { gas }}{\mathrm{Kr} / \mathrm{A} \text { air }}$ & $\frac{\mathrm{Xe} / \mathrm{A} \text { gas }}{\mathrm{Xe} / \mathrm{A} \text { air }}$ & $\frac{\mathrm{Xe} / \mathrm{Kr} \text { gas }}{\mathrm{Xe} / \mathrm{Kr} \text { air }}$ \\
\hline 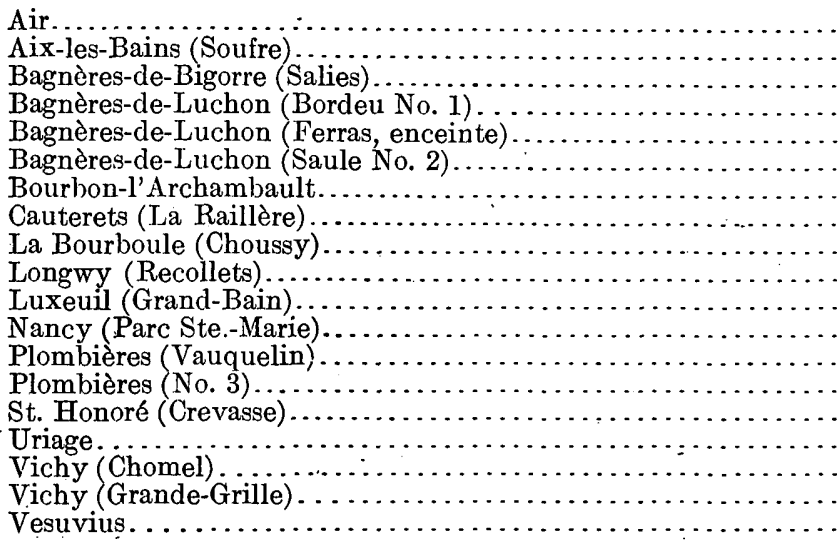 & $\begin{array}{r}1.00 \\
1.05 \\
1.17 \\
1.11 \\
1.08 \\
1.13 \\
.77 \\
1.19 \\
1.58 \\
1.18 \\
1.14 \\
1.14 \\
1.41 \\
1.23 \\
1.02 \\
.84 \\
1.40 \\
2.85\end{array}$ & 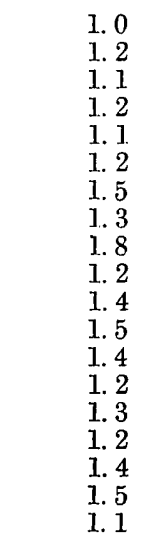 & $\begin{array}{l}\text { 1. } 0 \\
1.6 \\
1.6 \\
1.6 \\
1.2 \\
1.9 \\
1.6 \\
1.2 \\
2.2 \\
1.9 \\
1.6 \\
1.9 \\
1.9 \\
1.6 \\
1.2 \\
1.9 \\
1.9 \\
2.5 \\
1.2\end{array}$ & $\begin{array}{l}1.0 \\
1.3 \\
1.3 \\
1.3 \\
1.1 \\
1.6 \\
1.9 \\
1.2 \\
1.1 \\
1.3 \\
1.3 \\
1.3 \\
1.6 \\
1.3 \\
1.6\end{array}$ \\
\hline
\end{tabular}

a Moureu, Charles, and Lepape, A., Dosage spectrophotométrique du xénon; Constance des rapports xénon-argon et xénon-krypton dans les mélanges gazeux naturels: Compt. Rend., vol. 153, p. 740, 1911; Sur le rapport de l'argon à l'azote dans les mélanges gazeux et sa signification: Idem, vol. 152, p. 1533, 1911; Sur la constance du rapport du krypton à l'argon dans les mélanges gazeux naturels; Hypothèse explicative: Idem,

The following table shows the proportions of the rare gases, including helium, in the fire damp of certain coal mines:

Ratios of the rare gases in the fire damp of coal mines, as compared with their ratios in the atmosphere.a

\begin{tabular}{|c|c|c|c|c|c|}
\hline Mine. & - $\frac{\mathrm{A} / \mathrm{N}_{2} \text { gas }}{\mathrm{A} / \mathrm{N}_{2} \text { air }}$ & $\frac{\mathrm{Kr} / \mathrm{A} \text { gas }}{\mathrm{Kr} / \mathrm{A} \text { air }}$ & $\frac{\mathrm{Xe} / \mathrm{A} \text { gas }}{\mathrm{Xe} / \mathrm{A} \text { air }}$ & $\frac{\mathrm{Xe} / \mathrm{Kr} \text { gas }}{\mathrm{Xe} / \mathrm{Kr} \text { air }}$ & $\frac{\mathrm{He} / \mathrm{N}_{2} \text { gas }}{\mathrm{He} / \mathrm{N}_{2} \text { air }}$ \\
\hline 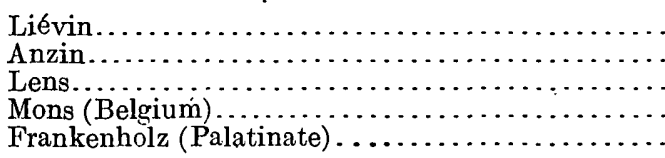 & $\begin{array}{r}1.38 \\
.97 \\
1.72 \\
.82 \\
.85\end{array}$ & $\begin{array}{l}1.4 \\
1.5 \\
1.3 \\
1.1\end{array}$ & $\begin{array}{l}1.2 \\
1.1 \\
.3 \\
2.1 \\
1.2\end{array}$ & $\begin{array}{l}0.9 \\
1.1 \\
.7 \\
1.6 . \\
1.1\end{array}$ & $\begin{array}{r}790 \\
3,470 \\
30 \\
23,100 \\
1,950\end{array}$ \\
\hline
\end{tabular}

a Moureu, Charles, and Lepape, A., Les gaz rares des grisous: Compt. Rend., vol. 153, p. 847, 1911; Sur les rapports des gaz rares entre eux et avec l'azote dans les grisous: Idem, p. 1043. 
The foregoing figures indicate a striking at Fillmore, Calif., and near Harre, Mont. constancy in the relative proportions of argon, The distribution of helium-bearing gas in the krypton, and xenon in the gases of springs, in United States is shown on the accompanying mine gases, in a volcanic gas, and in the air and index map (fig. 1).

lend considerable weight to the theory of Moureu and Lepape that all natural gaseous mixtures should contain these elements in about the same proportions. As noted above, the difference in the solubility of the rare gases in water prevents too strict an application of this

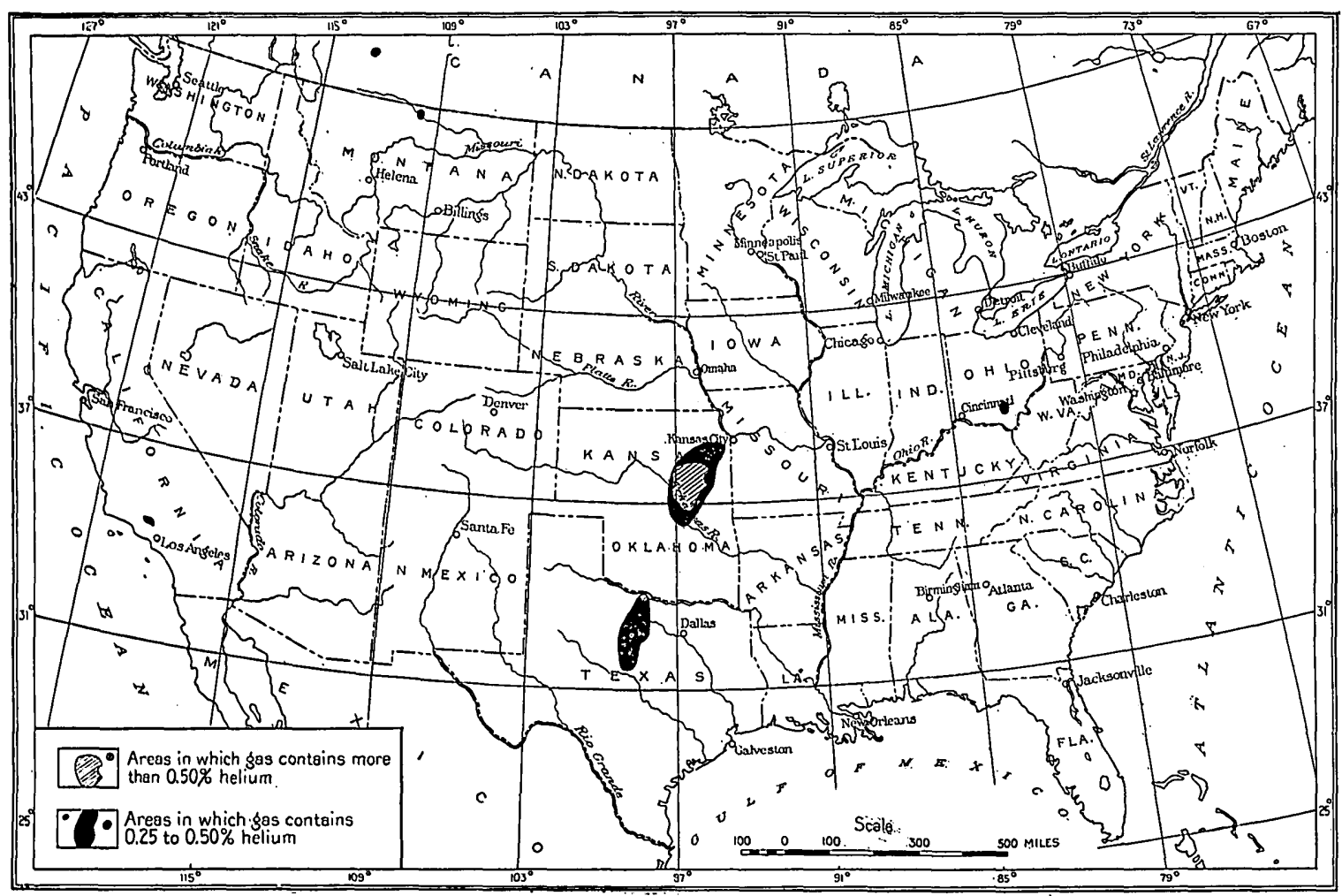

FIGURE 1.-Index map showing general distribution of natural gas rich in helium.

nearly all the gases that have been tested for them and their common association with helium appear to be satisfactorily explained.

\section{DISTRIBUTION AND RELATIONS OF HELIUM- BEARING NATURAL GAS.}

GENERAL OUTLINE.

Although most of the natural gas produced in the eastern and central parts of the United States contains at least a trace of helium, gas containing more than 0.5 per cent is known to occur only in two areas, one in northern Texas and the other in southern Kansas and northern Oklahoma. Gas containing from 0.25 to 0.5 per cent of helium is found on the borders of these areas and also in Vinton County, Ohio,
The helium-rich gas of the Kansas-Oklahoma area is confined to strata of middle and upper Pennsylvanian age, though gas carrying almost 0.5 per cent of helium occurs in the lower Ponnsylvanian. The Mississippian and Permian gases in that locality are poor in helium. Conditions in the Texas area are almost identi- 
ordinary natural gas. Some of the Kansas tended in those directions, it is possible that gases carry about 2 per cent of helium and 85 future discoveries will somewhat enlarge the per cent of nitrogen; the gas from Petrolia, helium-bearing district as here defined.

Tex., contains about 1 per cent of helium and almost 40 per cent of nitrogen; and the gas from Vinton County, Ohio, carries about 0.35 per cent of helium and 14 per cent of nitrogèn. On the other hand, not all high-nitrogen gases are rich in helium; many shallow gases in northern Oklahoma carry 30 to 40 per cent of nitrogen and yet contain less than 0.25 per cent of helium. (See p: 40.)

In the Kansas-Oklahoma area the gases richest in helium occur at shallow depths. In a given locality the helium content of the gas decreases with increasing depth, and it. also appears that the gas from a given formation is richer in helium where the formation occurs close to the surface than where it lies at considerable depth. In the Vinton County area, Ohio, however, the gas in the Berea sand at a depth of about 500 feet carries no more helium than that in the Clinton sand at about 2,300 feet.

\section{MID-CONTINENT REGION.}

LOCATION.

In the Mid-Continent region gas containing more than 0.5 per cent of helium occurs in an oval area lying chiefly in southeastern Kansas but extending a short distance into Oklahoma. This area extends about due south from Chase County, Kans., to Osage County, Okla., and eastward from western Butler County to Wilson County, Kans. Gas containing between 0.25 and 0.5 per cent of helium is found in the districts adjoining this area on the north, east, and south. As shown in Plate I, the total area in which gas containing more than 0.25 per cent of helium is found extends from Johnson County, in northeastern Kansas, to Payne County, in north-central Oklahoma.

As shown in Plate II the area richest in helium lies on the west-central edge of the great Mid-Continent oil and gas region, and its western limit is at present determined by the western limit of oil and gas development. The area of gas carrying more than 0.25 per cent of helium, however, includes the western half of the Mid-Continent petroleum. region. It is thus bounded on the north, west, and south by districts in which no oil or gas has yet been found. Although it is somewhat improbable that the producing areas will be greatly ex-

GEOLOGY.

GENERAL RELATIONS.

'The Mid-Continent oil and gas region, viewed broadly, lies in a great syncline or elongated basin, on the northeastern margin of which is the Ozark uplift. It is divided into two parts by the east-west belt of the Ouachita, Arbuckle; and Wichita mountains. The western border of the basin has not been definitely determined. There is paleontologic evidence to indicate that a varied body of uplifted Paleozoic rocks intervenes between the Mid-Continent field and the plains which border the Rocky Mountains on the east, but the presence of such an ancient land mass can not be regarded as established. The relations of the Mid-Continent area may best be understood by inspection of Plate II, which shows in generalized form the areal and structural geology of the whole region.

The prevailing dip of the rocks is toward the west. The dip ranges between about 15 feet to the mile in northern Kansas and about 80 feet to the mile in central Oklahoma, but locally the beds are horizontal or even inclined to the east, forming the terraces and anticlines that are so important in connection with the accumulation of oil and gas. Pennsylvanian strata form the surface rocks in the eastern and central parts of the petroleum region, but Permian formations appear near its western edge. Farther to the west the Permian strata are buried beneath Cretaceous beds, and these in turn by Tertiary formations. Nearer the Rocky Mountain front the general dip becomes easterly and the Cretaceous strata reappear, and at the base of the mountains the truncated edges of Permian, Pennsylvanian, Cambrian, and Ordovician formations are also exposed.

As shown in the structure section on Plate II, this great sedimentary basin is in a measure divided into at least two smaller basins by a narrow ridge or elevated portion of the preCambrian granite floor. This ridge has been reached by the drill at numerous points in Kansas; where its course and contour are fairly well defined, but it appears to plunge rather sharply to the south and has not been located in Oklahoma. The present petroleum-yielding region in Kansas lies almost wholly east of this ridge, or in the smaller of the two basins. 


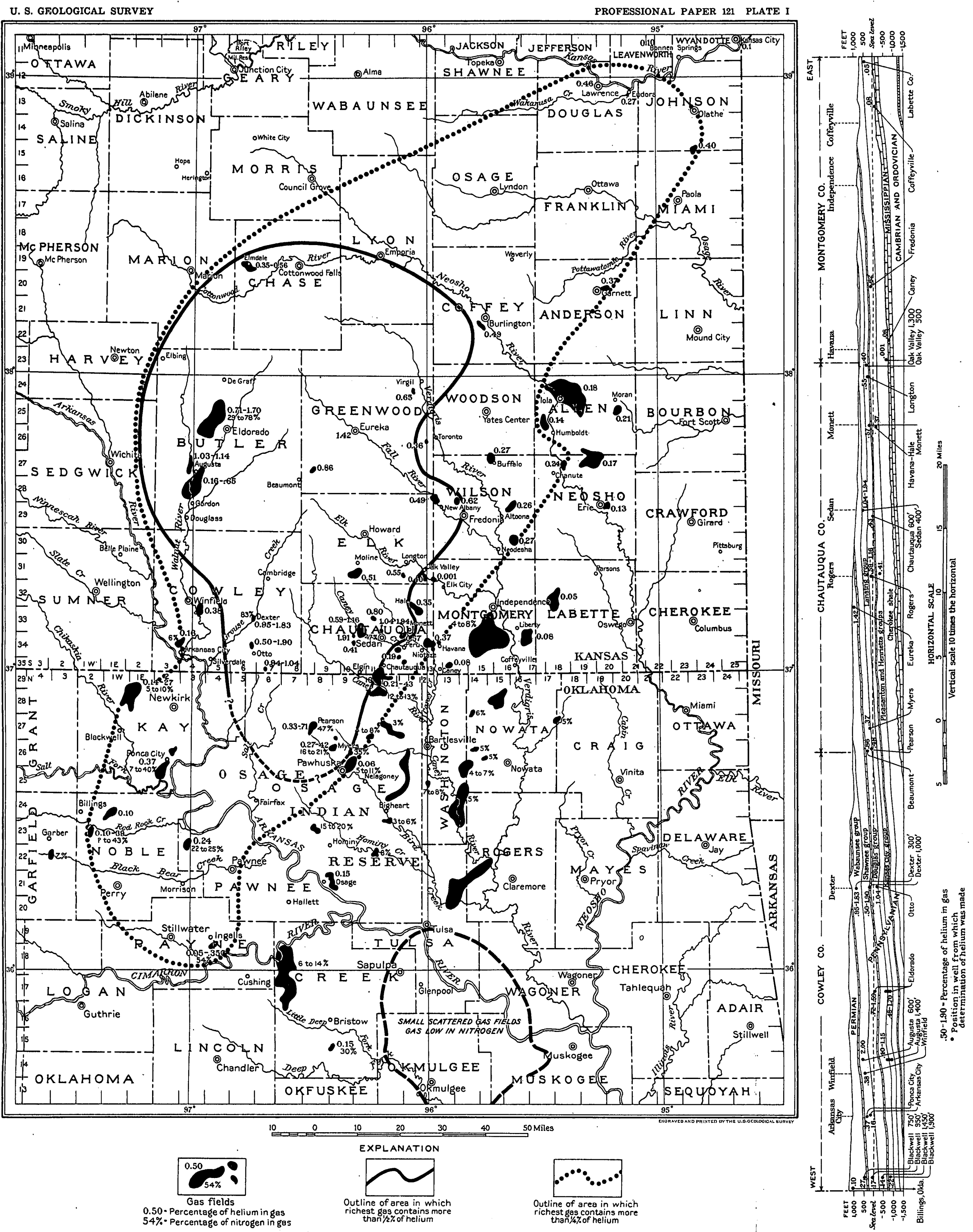

MAP OF SOUTHERN KANSAS AND NORTHERN OKLAHOMA GAS FIELDS, AND SECTION ACROSS COWLEY, CHAUTAUQUA, AND MONTGOMERY COUNTIES, KANSAS Showing distribution and quality of hellum-bearing gas 
The oil and gas occur very largely in strata of Pennsylvanian age, though some petroleum is also found in the upper Mississippian and in the basal Permian formations. The Pennsylvanian beds have a maximum thickness of about 3,500 feet in sou theastern Kansas, where they are underlain by about 2,500 feet of older Paleozoic sediments. Toward the west, however, or along the line of the pre-Cambrian granite ridge, all these older formations disappear, the granite being overlain directly by Pennsylvanian strata. This is the condition on the western edge of the helium-bearing area, though this area also extends to the east, where the pre-Cambrian rocks lie at considerably greater depth. Practically all the Pennsylvanian formations become thicker to the south, and in eastern Oklahoma the series aggregates many thousand feet in thickness. No helium is found in that district, however, and its geology need not be considered here.

CARBONIFEROUS FORMATTIONS. ${ }^{30}$

The petroleum-bearing rocks of the MidContinent area are wholly of Carboniferous age, and the great bulk of the oil produced is obtained from the lower and middle parts of the Pennsylvanian series. Owing to the westerly dip the upper.portion of the Permian series crops out only in central Kansas and need not be considered here, but the character and classification of the lower Permian formations and of the Pennsylvanian and Mississippian beds are shown graphically in figure 2.

The Permian of Kansas consists of two very distinct lithologic and stratigraphic units, the upper of which, consisting of nonmarine red shale and sandstone, does not crop out within the area under discussion. The lower unit consists of marine shale, limestone, and sandstone and is very similar lithologically to the underlying Pennsylvanian series. The total thickness of this unit is probably about 1,100 feet, but only the basal formations, aggregating about 400 feet in thickness, are exposed in the known helium-bearing area.

The Pennsylvanian series in southeastern Kansas has a maximum thickness of about 3,500 feet. As shown in figure 2 the uppermost Pennsylvanian has been divided into a number of thin and relatively unimportant

${ }^{50} \Lambda$ more detailed description of the Carboniferous formations in Kansas is given by R. C. Moore and W. P. Haynes (Oil and gas resources of Kansas: Kansas Geol. Survey Bull. 3,pp. 84-123, 1917).

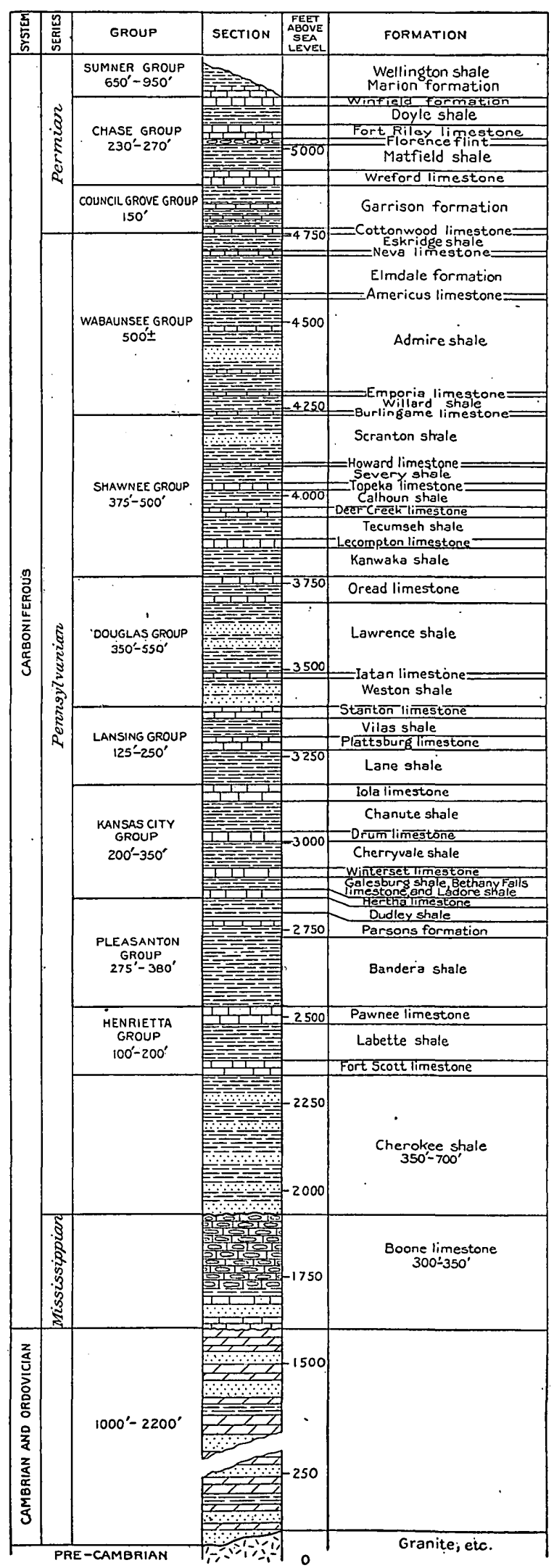

Figure 2.-Generalized section of formations in eastern Kansas. 
formations known collectively as the Wabaunsee group. This group is underlain by the Shawnee, Douglas, Lansing, Kansas City, Pleasanton, and Henrietta groups, and the Cherokee shale, which have themselves been subdivided into the formations shown in the columnar section. Although many of these formations, especially the limestones, are remarkably persistent and may be traced throughout most of eastern Kansas, the Pennsylvanian series as a whole, together with the lower half of the Permian, constitutes a broad lithologic unit. All the upper and middle Pennsylvanian rocks consist of alternating beds of shale, limestone, and sandstone. The shale is by far the most abundant; the limestone beds are generally less than 25 feet thick, and the sandstones are commonly thin and discontinuous. The Cherokee formation differs somewhat from the remainder of the series in that it contains fewer limestone beds and more sandstones, which, though inconspicuous as stratigraphic units, are of great economic importance as oil sands.

The Mississippian series, which crops out in the extreme southeast corner of Kansas, consists chiefly of crystalline limestone with a considerable proportion of hard chert. In eastern Kansas the series is not more than 350 feet thick, and along the granite ridge on the west edge of the oil and gas region the Mississippian is entirely absent. It has not been encountered by wells drilled west of this belt, though it may be present locally in western Kansas, as suggested in the stratigraphic section in Plate II. The upper surface of the Mississippian in eastern Kansas is very irregular, varying in elevation as much as 75 feet in a distance of half a mile, but its general inclination is not markedly different from that of the overlying Pennsylvanian beds. The Mississippian rests unconformably on the older Paleozoic formations.

PRE-CARBONIFEROUS FORMATIONS.

Beneath the oil-bearing rocks of the Carboniferous system lies a considerable thickness of Paleozoic formations which rest directly on the granite of the pre-Cambrian basement. These older formations do not crop out in Kansas but may be studied in the Ozark uplift of Missouri and on the Rocky Mountain front.
On the northern and western flanks of the Ozark uplift Silurian and Devonian formations are exposed, but as these formations are absent in most of the Rocky Mountain area, they may not underlie much of the Kansas region. The chief formations involved in the Ozark uplift are of Cambrian and Ordorician age and consist of 2,000 to 2,500 feet of dolomite and limestone, with some sandstone and shale. In Colorado, however, the equivalent formations have a maximum thickness of only about 300 feet and in many localities they are lacking. It is evident, therefore, that the Cambrian and Ordovician beds become much thinner toward the west, though they doubtless underlie much of the Kansas region. As these beds were laid down directly on the granite basement and were subjected to uplift and erosion before the deposition of the Mississippian sediments their thickness from place to place presumably depends in part on the contour of the granite floor.

The granite and other crystalline rocks forming the basement on which the sedimentary formations described above were deposited are not exposed in Kansas but crop out in eastern Missouri, in the Rocky Mountains, in the Wichita and Arbuckle uplifts of southern Oklahoma, and in the southern parts of Minnesota and South Dakota. It was formerly supposed that the pre-Cambrian rocks underlie the Kansas region only at great depth, but drilling within the last few years has revealed the presence of granite at comparatively shallow depths in a zone extending through eastcentral Kansas and at somewhat greater depths at several isolated localities in the eastern part of the State. ${ }^{31}$ The coarse grain of the crystalline rocks and the unmetamorphosed character of the sediments immediately overlying them indicate beyond question that they are a part of the original basement and are not recent intrusions.

The granite lies nearest to the surface in northern Kansas, where it is encountered at a depth of only about 600 feet, but as far to the south as Chase County it lies in general within 2,000 feet of the surface. In that locality it appears to drop off sharply, but it is reported that granite has recently been encoun-

st A comprehensive description of these crystalline rocks is given by R. C. Moore and W. P. Haynes (op. cit., pp. 140-173). 


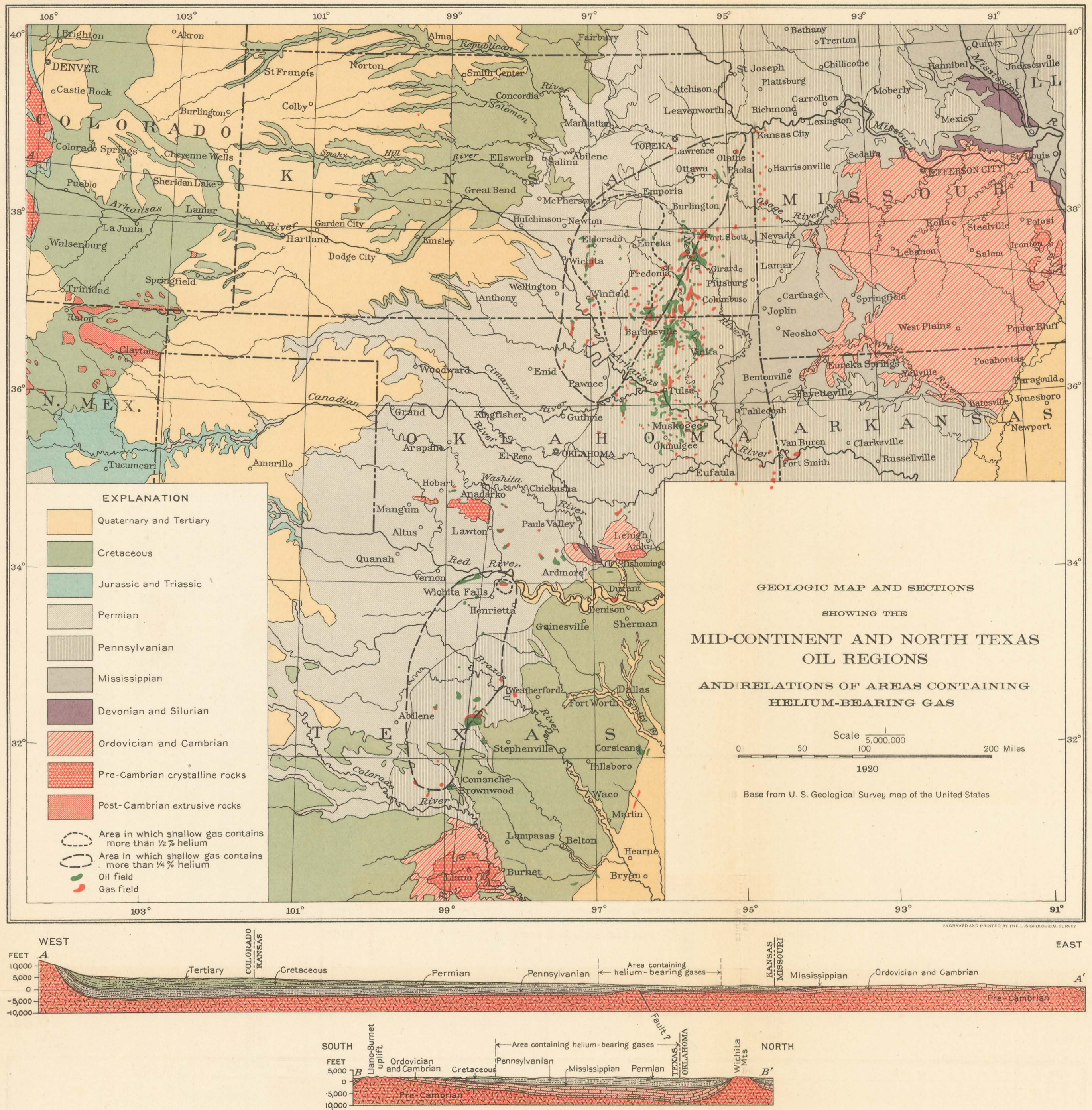


tered at a depth of about 4,000 feet in the Mississippian. On the other hand, a well at Augusta field, in Butler County. The avail- Iola, only about 20 miles east of the Woodson able information regarding this so-called County well, entered the Mississippian at 1,040 granite ridge is summarized in figure 3, which feet, and though it was drilled to 3,434 feet no shows the wells that have encountered granite granite was recorded. It seems, therefore, and the depth at which they found it, and also the location and depth of other wells in this belt that did not reach the granite. As shown by the structure section, all the Mississippian and older formations and much of the Pennsylvanian are lacking in the northern part of the granite belt, though in Butler County the whole of the Pennsylvanian and Mississippian series are probably present.

The relations of the sedimentary formations to the granite ridge indicate that the ridge was formed prior to the Pennsylvanian epoch. The small size of the elevated mass suggests, however, that it could not have remained long above sea level without being reduced by erosion, and furthermore, the Mississippian and older formations of eastern Kansas contain little clastic material, such as a near-by granite land mass would furnish; hence it is thought that the ridge was elevated at the end of the Mississippian epoch. The Cambrian, Ordovician, and Mississippian formations were probably laid down throughout this area, but at the end of Mississippian time there was a period of uplift and erosion, as indicated by the uneven upper surface of the Mississippian itself. Differential uplift at this time probably led to the formation of the long, narrow granite ridge, and during the ensuing period of erosion all the sedimentary formations were apparently removed from this elevated area. When resubmergence of the surrounding country took place at the beginning of Pennsylvanian time most of the granite ridge remained an island, and it was not completely submerged until the end of the Shawnee epoch.

As shown in figure 3, a well in Riley County, distinctly to the west of the main ridge, found granite at a depth of 2,385 feet, which may indicate simply a shoulder on the western slope of the main ridge or may represent another and distinct protuberance of the granite basement. Similarly a well in Woodson County, far to the east of the main ridge, found granite at 2,585 feet, or only about 700 feet beneath the base of the Mississippian. A well at Paola, Miami County, is reported to have reached granite at 2,260 feet, or about 1,000 feet below the that the granite basement is irregular in contour and that there may be other though less prominent ridges elsewhere in eastern Kansas.

As the main granite ridge is coincident with the western border of the helium-rich area (though also extending far to the north and probably to the south of it), its structural relations are of special interest in connection with the source of the helium. The great length and small width of the elevated area and also the dense and crystalline character of the rock involved strongly suggest that the ridge is an elevated fault block, or at least that one of its sides, probably the eastern, is determined by a fault. A. E. Fath, ${ }^{32}$ of the Geological Survey, who. has given special attention to the mechanics of the structure of the Mid-Continent region, is in favor of this view and believes, moreover, that the basement rocks throughout the region are probably extensively fissured and that recent movements along these fissures have produced the many minor wrinkles that characterize the surface rocks of the region. Among his reasons for this belief are the following: (1) The rocks above the granite ridge lie in very prominent anticlines which in places represent structural elevations of over 200 feet. This fold is too large to be explained by differential settling and can best be accounted for by thrust from below. (2) The presence of granite at moderate depth at several isolated localities in eastern Kansas suggests that there may be elsewhere similar elevations in the granite floor. (3) In Kansas and Oklahoma there are many anticlines parallel to the granite ridge which, though representing uplifts of only a hundred feet or so, can be traced across several counties. It is unreasonable to suppose that such regular and persistent structural features were produced by lateral thrusts which, so far as present knowledge indicates, must have originated several hundred miles east and west of the area. (4) The surface rocks in parts of northern Oklahoma

32 Personal communication. Mr. Fath discusses his views at length in a paper entitled "The origin of the faults, anticlines, and buried 'granite ridge' of the northern part of the Mid-Continent oil and gas field" (U. S. Geol. Survey Prof. Paper 128, pp. 75-84, 1920). 


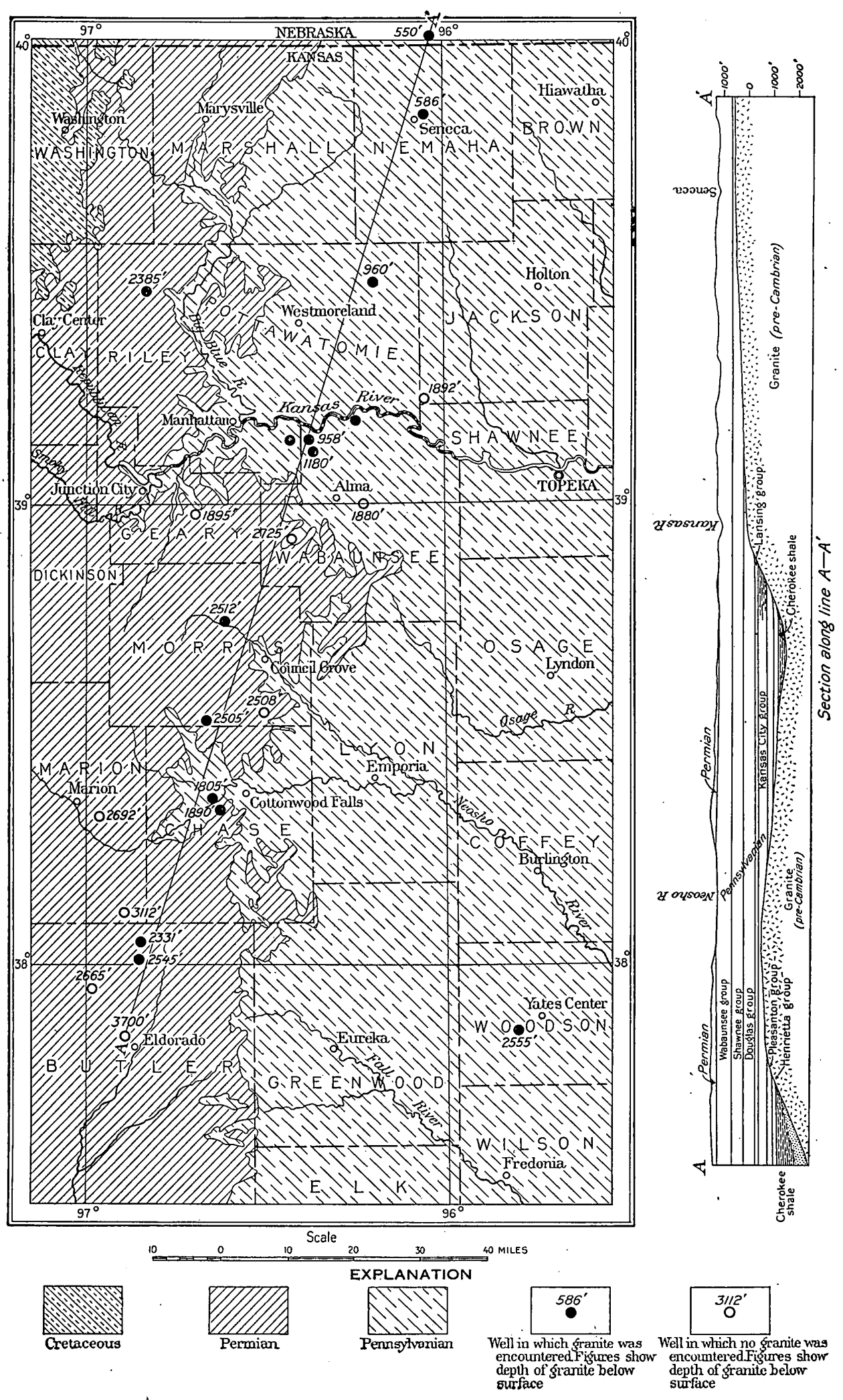

FIGURE 3.-Map of portion of eastern Kansas showing depth and relations of the granite ridge. 
are broken by many small parallel faults which occur in zones that may be traced for many miles and that are essentially parallel to the granite ridge and to the main anticlines. These faults can also best be explained as faint surface reflections of more extensive movements of the pre-Cambrian floor.

Although the contour of the granite ridge itself forms the most direct basis for assuming a fault in the pre-Cambrian rocks, the lines of evidence brought together by Mr. Fath thus furnish excellent reasons for suspecting the presence of many similar fault lines. This possibility is of special interest in connection with the source of the helium, as discussed on pages $66-67$.

\section{STRATIGRAPHIC DISTRIBUTION OF THE HELIUM.}

Viewed broadly, the helium content of natural gas is related to the stratigraphic position of the producing sands, though the relation is by no means precise. Cady and McFarland, in their report on the helium-bearing gas of Kansas, presented a map showing "iso-helium" lines, which, as they pointed out, had a general similarity in trend to the outcrops of the geologic formations. The numerous analyses now available indicate, however, that such lines can not be drawn, for the factors of the geographic location and depth beneath the surface must be taken into account, as well as the factor of stratigraphic position.

The generalized structure section on Plate I shows the helium content and relative stratigraphic position of a number of natural gases from southern Kansas and northern Oklahoma. It will be noted at once that the gases richest. in helium occur in middle and upper Pennsylvanian strata. The one sample of Mississippian gas collected in the fields adjacent to the line of the section contained only 0.08 per cent of helium. Three samples of gas from the Cherokee shale contained, as shown in the section, less than $0.1 \mathrm{per}$ cent of helium. The gases of the overlying Henrietta and Pleasanton groups are considerably richer, three samples averaging 0.47 per cent. The Kansas City group, however, is the lowest in which gas carrying more than 1 per cent of helium has been found, and similarly rich gases occur in all the overlying Pennsylvanian beds. The Permian gases, on the other hand, are poor in helium, the two samples plotted in the section showing only 0.27 and 0.1 per cent.
In a broad sense, therefore, gases containing more than 0.5 per cent of helium seem to occur only. in the strata between the top of the Wabaunsee group and the base of the Kansas City group, a stratigraphic range of about 2,000 feet. If this conclusion is correct it follows that the area of gas carrying more than 0.5 per cent of helium is bounded on the east by the line along which the Kansas City group lies at a depth of 200 feet or so, for commercial accumulations of gas can hardly be expected at depths shallower than.this. The western limit of the area, however, is not determined by stratigraphic considerations, but it is defined at present simply by the western limit of oil and gas development. Should this development be extended a considerable distance farther west, it may be presumed that the factor of depth will determine the western limit of the helium-rich area, for, as described below, gases rich in helium apparently do not occur at depths greater than about 1,600 feet. The top of the Pennsylvanian series probably reaches this depth within 25 miles to the west of the known helium-rich area.

Although stratigraphic considerations serve to define the outer limits of the heliumbearing zone, it is evident that the helium content of the gases within the zone varies greatly. Individual samples from approximately the same horizon in the Augusta field range in helium content from 0.2 to $1.1 \mathrm{per}$ cent, and samples from the Sedan field from 1 to 2 per cent. Similarly the gas at Otto, Kans., which carries 1.04 per cent of helium, occurs at about the same horizon as the gases of the Pearson and Myers fields, Oklahoma, which average only 0.48 and 0.37 per cent. Furthermore, the north and south limits of the heliumrich area are not related to stratigraphy or structure, and gases within the area that carry more than 2 per cent of helium occur at the same general horizon as those outside that carry less than 0.25 per cent.

Although the helium-rich gas of the MidContinent area thus occurs characteristically in upper and middle Pennsylvanian formations, it is found in those formations only in a certain area, and even in that area its vertical and horizontal distribution is irregular.

VARIATION IN HELIOM CONTENT WITH DEPTH.

The helium content of gases in the MidContinent field is generally related to the depth 
at which the gases occur, deep gases being poorer in helium than shallow ones. The gas occurring at a depth of 1,475 feet at Otto, Kans., contains about 1 per cent of helium, but nowhere else in the region is equally rich gas known to occur below 1,200 feet. On the other hand, gas carrying more than 1.75 per cent of helium has been discovered only in the Augusta, Dexter, and Sedan fields, and in all of these it occurs at depths of less than 600 feet. The gases richest in helium are high in nitrogen and being thus of little value for heating are known in the fields as "wind gas"; and it is generally recognized by oil and gas operators that wind gas occurs characteristically at shallow depth.

In most fields in which there are two or more gas sands the shallowest gas is richest in helium. At Augusta, for example, the 600-foot gas contains 2 per cent of helium and the 1,500-foot gas averages only 0.5 per cent. At Eldorado the 900 -foot gas averages 1.2 per cent, and the 1,200-foot gas 1 per cent. At Sedan the 400foot gas averages more than 1.5 per cent, whereas the 700 -foot gas carries only about 1 per cent.

Owing to the fact that the dip of the strata throughout the Mid-Continent field is comparatively gentle, vertical and stratigraphic distances are about the same, and in some localities it is difficult to decide whether the helium content of the gas is influenced more by its depth beneath the surface or by its stratigraphic position. It seems clear, however, that the gas from a given formation is likely to be richer in helium in localities where the formation lies at shallow depth than where it occurs at greater depth. This is shown in the structure section on Plate I, though it must be admitted that the relation is rather irregular and vague. On the other hand, in some localities the factor of depth seems to be less important than that of stratigraphic position. In the Billings field, for example, the 500-foot gas which occurs in the Permian contains only 0.1 per cent of helium, whereas the 1,000 -foot gas, which probably occurs in the uppermost Pennsylvanian strata, carries 0.39 per cent. Similarly the gas of the Cherokee shale in eastern Kansas seems to be uniformly poor in helium, though it occurs in many localities at shallow depths.
NORTH TEXAS REGION.

\section{LOCATION.}

The only field in Texas in which gas containing more than 0.5 per cent of helium has yet been found is the Petrolia field in Clay County. Gas carrying more than 0.25 per cent of helium, however, occurs throughout a considerable area lying to the south and southwest of Petrolia and extending from that field to Coleman and Brown counties. This area lies mostly to the west of the great north Texas oil and gas fields, but it is a district in which prospecting and development are now very active. It is probable, therefore, that the boundaries of the area as shown on Plate III, especially the western boundary, will be changed by future developments.

All sources of supply in northern and central Texas and southern Oklahoma were sampled at the time of the writer's visit, in July, 1918. The location of the gas fields and the helium content of their product are shown in more detail in Plate III.

\section{GEOLOGY.}

The north Texas oil and gas region lies near the eastern rim of the great Carboniferous basin which underlies most of western Texas and eastern New Mexico. Toward the west this basin extends northward without interruption into western Oklahoma and Kansas, but on the east it is partly separated from the Mid-Continent basin by the Wichita and Arbuckle uplifts of southern Oklahoma. The north Texas petroleum region thus lies between these two areas of disturbance on the north and the Llano-Burnet uplift on the south, and its structural features are greatly influenced by its position with regard to them. The areal and structural geology of the region is shown in generalized form on Plates II and III.

The oil-bearing rocks of the north Texas region are of Carboniferous age, and Carboniferous formations also constitute the surface rocks throughout most of the region. PreCarboniferous beds do not crop out within the helium-bearing area and have not been penetrated by the drill except in its southern portion, but they may be studied in the LlanoBurnet uplift, to the south, and in the Wichita and Arbuckle mountains, to the north. The 


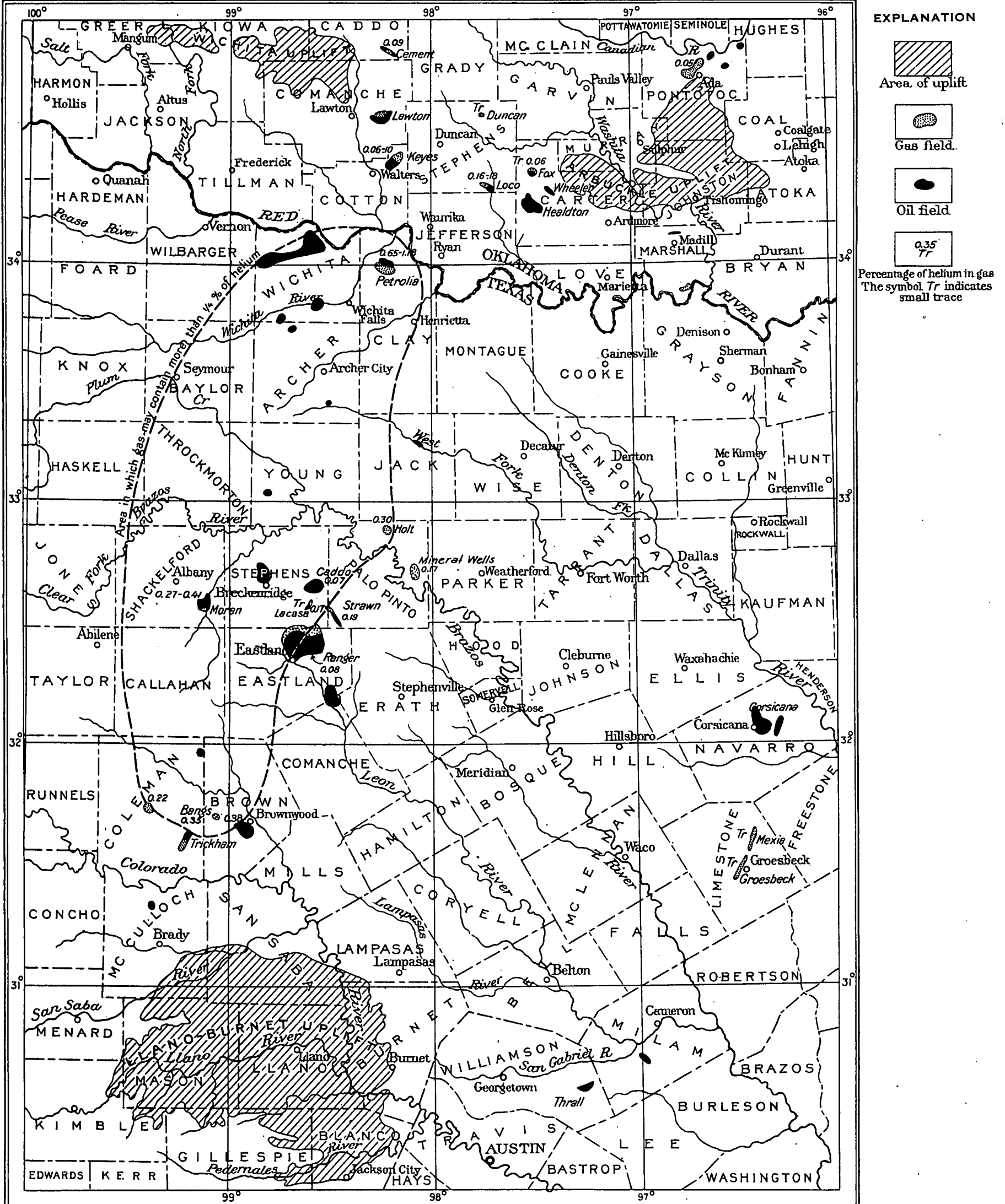

MAP OF NORTHERN TEXAS AND SOUTHERN OKLAHOMA

Showing oll and gas flelds, distribution of hellum-bearing gas, and relations of flelds to area of uplift

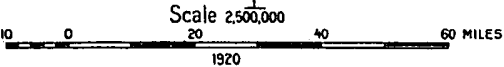


formations involved are shown in the accompanying columnar section. (fig. 4), in which the data regarding the pre-Carboniferous for-

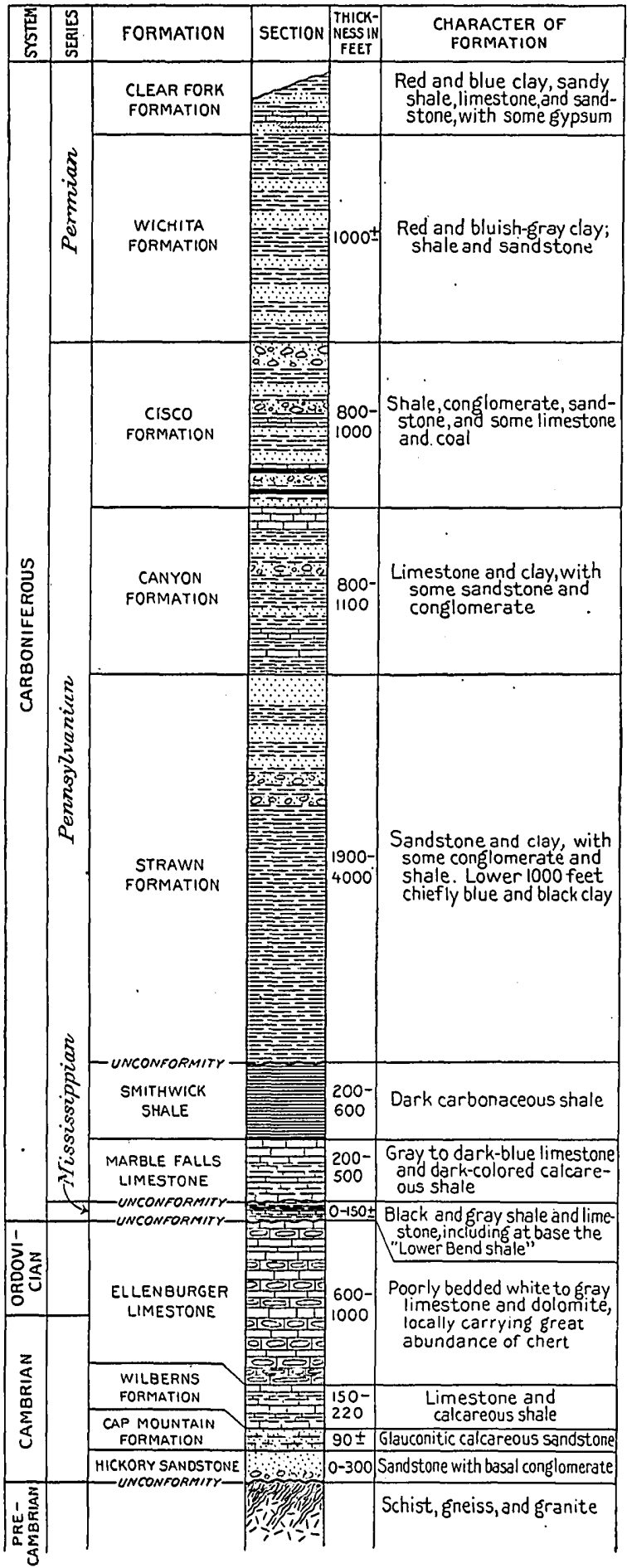

Fioure 4.- Generalized columnar section of formations in north-central Toxas. The thicknesses of the pre-Carboniferous formations are those measured by Paige in the Llano-Burnet uplift. The equivalent formations in the Wichita and Arbuckle uplifts are very much thicker; hance in tho north Texas oil region they are doubtless considerably thicker than here shown. mations are based on observations in the Llano-Burnet district.

The formations exposed in the Llano-Burnet area have been described in detail by Paige. ${ }^{33}$ The oldest rocks are granite, schist, and gneiss, with igneous intrusions, and are probably of Algonkian age. These rocks are surrounded by a rim of Cambrian and Ordovician beds dipping outward from the center of the uplift: As shown in the columnar section these rocks consist chiefly of limestone, dolomite, and calcareous sandstone and shale, with a conglomerate at the base, and aggregate 950 to 1,600 feet in thickness. In the Wichita Mountains, however, the pre-Pennsylvanian formations, according to Taff, ${ }^{34}$ have a very much greater thickness. The earliest Cambrian formation in the Wichita Mountains is similar in character and thickness to the Hickory sandstone of Texas, but it is overlain by a Cambrian and Ordovician formation, the Arbuckle limestone, which is 4,000 to 6,000 feet thick. The only other pre-Carboniferous formation exposed in the Wichita Mountains is an Ordovician limestone about 300 feet thick, but in the Arbuckle Mountains, 60 miles to the east the formations present include the Simpson formation and the Viola limestone of Ordovician age, aggregating 2,000 to 2,500 feet in thickness; the Sylvan shale, also of Ordorician age, 60 to 300 feet thick; the Chimaneyhill limestone, 53 feet thick, and the Henryhouse shale, 223 feet thick, of Silurian age; the Haragan shale, 161 feet thick, the Bois d'Arc limestone, 90 feet thick, and the Woodford chert, about 650 feet thick, all of Deronian age.

The aggregate thickness of pre-Carboniferous formations in the Arbuckle Mountains is 6,900 to 10,250 feet, and although in the Wichita Mountains only 4,500 to 6,600 feet of preCarboniferous rocks are exposed, it is possible that several thousand feet more of these beds are present but are concealed by the mantle of Permian formations that unconformably overlies them. Whether this is so or not, however, it is evident that the pre-Carboniferous beds are very much thicker in southern Oklahoma than in the Llano-Burnet area in central Texas,

ss Paige, Sidney, U. S. Geol. Survey Geol. Atlas, Llano-Burnet folio (No. 183), 1912.

34 Taff, J. A., Preliminary report on the geology of the Arbuckle and Wichita mountains, in Indian Territory and Oklahoma: U. S. Geol. Survey Prof. Paper 31, 1904. 
where they have a maximum thickness of only 1,600 feet. Beneath the northern part of the helium-bearing district, therefore, these formations are probably from 3,000 to 6,000 feet thick, unless, as in Kansas, there are irregularities in the pre-Cambrian floor that cut out some of the basal beds. This possibility is disregarded in the representation of the structure of the pre-Carboniferous rocks and their thickening to the north in the structure section on Plate II.

The Cambrian and Ordovician limestone in the Llano-Burnet area is unconformably overlain by the Marble Falls limestone, of Pennsylvanian age. Just north of that area, however, the Marble Falls is separated from the Ordovician by limestone and shales believed to be of upper Mississippian age. The lower part of these Mississippian beds has been called "Lower Bend shale." 35 The Marble Falls limestone is overlain by the Smithwick shale, and the Smithwick is unconformably overlain by the Strawn formation. Because of the unconformities at the base of the so-called "Lower Bend shale," at the base of the Marble Falls, and at the top of the Smithwick, the combined thickness of these formations varies considerably, though in general it increases somewhat toward the north. On the outcrop, where the Mississippian is absent, the Smithwick and Marble Falls together are 550 to 850 feet thick, but in the Ranger district the combined thickness of the three formations is almost 1,000 feet. $^{36}$ The highly prolific oil sands encountered at depths of 3,000 to 3,500 feet in the Ranger, Breckenridge, Caddo, and neighboring pools occur in the "Bend series," mainly in the Marble Falls limestone, and chiefly in its upper portion, and one or two wells have also found oil and gas in the overlying Smithwick shale.

The Smithwick shale is overlain by the Strawn, Canyon, and Cisco formations, of Pennsylvanian age, which consist chiefly of sandstone and shale with some coal. Cummins, ${ }^{37}$ Drake, ${ }^{38}$ Hill, ${ }^{39}$ and others have shown that the Strawn formation is about 2,500 feet thick in the neighborhood of Strawn, Palo Pinto County, and in some places reaches a

\footnotetext{
${ }_{35}$ Udden, J. S., Review of geology of Texas: Texas Univ. Bull. 44, pp. $41,42,1916$

${ }_{36}$ Tatteson, W. G. A review of development in the new central Texa oil fields during 1918: Econ. Geology, vol. 14, p. 95, 1919.

37 Cummins, W. F., Texas Geol. Survey Second Ann. Rept., 1891.

${ }_{38}$ Drake, N. F., Texas Geol. Survey Fourth Ann. Rept., 1893
}

thickness of 4,000 feet. Its thickness in north Texas, however, as measured by Gordon, ${ }^{40}$ is only 1,900 feet. The Strawn consists chiefly of blue to black shale and reddish sandstone. It includes several workable coal beds and the oil sands that are productive chiefly in Palo Pinto County. The Strawn is overlain by the Canyon formation, which is 800 to 1,100 feet thick and which consists chiefly of shale and limestone in the Ranger region but becomes more sandy toward the north. Matteson ${ }^{41}$ has called attention to the pronounced unconformity between the Strawn and Canyon formations in the Ranger region and in north-central Texas generally. The Canyon is overlain by the Cisco formation, which is 800 to 1,000 feet thick and which consists chiefly of red to blue shale and reddish sandstone. The heliumbearing gas of the Petrolia field and much of the oil of the Electra and Burkburnett fields probably occur in the Cisco formation.

In northern and central Texas sedimentation was not interrupted at the end of the Pennsylvanian epoch, and the great series of Permian. beds rests conformably on the Pennsylvanian strata. The lowest Permian formation, the Wichita, is lithologically very similar to the Cisco formation and yields the shallow oil of the Petrolia, Electra, and Burkburnett fields. . The Wichita, which is 1,000 to 1,200 feet thick, is overlain by the Clear Fork and Double Mountain formations, which have a combined thickness of almost 4,000 feet, but these beds crop out west of the area under discussion and need not be considered here.

The conditions of sedimentation in 'southern Oklahoma differed from those in Texas in several particulars. As already noted, the thickness of the pre-Carboniferous formations in southern Oklahoma is very much greater than in Texas, and in the Arbuckle Mountains, at least, sedimentation continued without notable interruption through Mississippian time. At the end of the Mississippian, however, the Arbuckle region was uplifted into land, and so it remained during a great part of Pennsylvanian time. During this epoch only a comparatively small thickness of strata was deposited in the Arbuckle region proper, though in central and northern Texas the thick series of beds repre-

${ }^{40}$ Gordon, C. H., Geology and underground waters of the Wichita region, north-central Texas: U. S. Geol. Survey Water-Supply Paper 317 , p. 14, 1913

11 Matteson, W. G., Econ. Geology, vol. 14, p. 105, 1919 
sented by the Marble Falls, Smithwick, Strawn, Canyon, and Cisco formations was laid down. Moreover, near the end of the Pennsylvanian the sediments of the Arbuckle region were again folded and elevated into land, and a great hiatus occurred between the deposition of the highest Pennsylvanian formations and that of the lowest Permian. During the same period sedimentation in north Texas, resulting in the formation of the Wichita and Cisco beds, was practically continuous; hence in southern Oklahoma part or all of the Wichita and Cisco and perhaps still lower beds are absent. The exact conditions can not be determined, except in the immediate vicinity of the Arbuckle uplift, for elsewhere all the older rocks are unconformably overlain by a blanket of Permian beds; hence at present it is impossible to correlate the oil and gas zones of southern Oklahoma with those of northern Texas.

That the tectonic relations of the north Texas region are complex and difficult to decipher is clear from the foregoing discussion. It is evident that the pre-Carboniferous rocks form a sort of basin between the Llano-Burnet uplift on the south and the Wichita and Arbuckle uplifts on the north. Although there is no marked discordance in dip in the Llano-Burnet region between these formations and the Carboniferous, farther north the upper surface of the pre-Carboniferous is very irregular and its structure may be very different from that of the Carboniferous formations. In the LlanoBurnet district the lower Pennsylvanian beds have a general northerly dip, and in the Ranger region they are known to dip also to the east and west, forming a broad, gentle anticline whose northward-plunging axis is a radial extension of the Llano-Burnet uplift. The Strawn and higher formations dip in general to the northwest, their structure being controlled in part by the Llano-Burnet uplift and in part by their position on the eastern rim of the great Carboniferous basin of west Texas. The Permian beds in Texas are conformable to the Pennsylvanian, but in southern Oklahoma they are unconformable and conceal the complicated structure which undoubtedly characterizes all the older formations in that area.

\section{DISTRIBUTION OF THE HELIUM.}

The gas produced in all the fields of northern and central Texas and southern Oklahoma has been tested for helium, and the results are shown on Plate III. It will be noted that the only field producing gas carrying more than 0.5 per cent of helium is Petrolia, that gas carrying more than 0.25 per cent is found throughout a large area south of Petrolia, and that all the southern Oklahoma fields yield gas very poor in helium. As the fields in this region are fewer than those in the Mid-Continent region and are also more widely separated, it is even more difficult to draw definite conclusions as to the factors covering the distribution of the helium, though its broader stratigraphic relations are plain. The rich Petrolia gas occurs in the upper Pennsylvanian, and the poorer gases to the south in the lower Pennsylvanian. The Permian gases of southern Oklahoma and the basal Pennsylvanian and Mississippian gases of the Ranger region are poor in helium, and the Cretaceous gases of east-central Texas and Louisiana contain only traces of helium or none at all. The stratigraphic distribution of the helium in this region is thus similar to that in the Mid-Continent district; the richest gases are of upper and middle Pennsylvanian age, and both older and younger gases are poor.

The Petrolia gas, which carries almost 1 per cent of helium, is derived from a zone of sands that lies at a depth of 1,500 to 1,750 feet and is believed to occur in the Cisco formation. The gas sands are lenticular and can not be traced for any great distance, but there appear to be two main producing groups of sands, one lying at an average depth of about 1,550 feet and the other at about 1,700 feet. A less definite zone occurs between the two, and "stray" sands are also reported in many wells. Samples collected from individual wells show a range in helium from 0.65 to 1.18 per cent, and the gas from the uppermost group of sands is apparently slightly richer than that from the others. As all these groups, however, lie in one general zone, and as no gas is produced from other zones in the field, it is impossible to determine how far the helium content of the gas is related to its depth or its exact stratigraphic position.

The Petrolia field is the only locality in which gas is produced from sands that are almost certainly in the Cisco formation. In the Electra and Burkburnett fields, a short distance west of Petrolia, oil is obtained from sands in the Cisco and in the overlying Permian, but no commercial supplies of gas have been found. 
In the southern part of Throckmorton County several wells found small supplies of gas that may occur in the Cisco, and two samples of this gas showed 0.73 and 0.22 per cent of helium. These samples were not collected by the writer, however, and as there is considerable doubt as to the source of the richer sample, little significance can be attached to it.

Practically all the gas and oil produced in the Ranger region are derived from the Strawn, Smithwick, and Marble Falls formations. The gas of the Palo Pinto County fields occurs mostly in the lower part of the Strawn formation, and five samples of it ranged in helium content from 0.17 to 0.32 per cent. The gases of the Moran and Breckenridge fields occur higher up in the Strawn and carry 0.27 to 0.44 per cent of helium. The gas of the Caddo and Ranger fields, which occurs in beds beneath the Strawn formation, carries less than 0.1 per cent. The two gases sampled in Coleman County, which occur in the upper Strawn or lower Canyon beds, carry less than 0.25 per cent. The Brown County gases occur in the Strawn formation and carry 0.35 to 0.38 per cent.

Four samples of Cretaceous gas from the Mexia and Groesbeck fields, southeast of the Ranger region, contained only traces of helium, and gas from the Thrall field, which occurs in a body of porous serpentine in Cretaceous rocks, contains none. Four samples of Cretaceous gas from the northern Louisiana fields contained from 0.03 to 0.07 per cent of helium. Tertiary gases from the Jennings ranch, in Zapata County, southern Texas, and from the Jennings and Houma fields, southern Louisiana; contained only traces of helium.

The low helium content of the gases of the southern Oklahoma fields, which are located not far from Petrolia and in a district in which the surface geology is similar, is at first sight surprising, but it can probably be accounted for on stratigraphic grounds. The gas of the Loco field, ${ }^{42}$ which contains about 0.15 per cent of helium, and that of the Duncan field, ${ }^{43}$ which carries only a trace, occur in Permian strata, as does also the gas at Lawton, ${ }^{44}$ which contains only 2 per cent of nitrogen and is therefore pre-

42 Wegemann, C. H., The Loco gas field, Stephens and Jefferson coun ties, Okla.: U. S. Geol. Survey Bull. 621, p. 31, 1916.

18 Wegemann, C. H., The Duncan gas field, Stephens County, Okla.: Idem. p. 43 .

14 Wegemann, C. H., and Howell, R. W., The Lawton oil and gas field, Okla.: Idem, p. 71 . sumably very poor in helium. The gases of the Ada, Cement, Fox, and Keyes fields, which all contain less than 0.1 per cent of helium, occur below the base of the Permian, but their position in the Pennsylvanian is not known. As already pointed out, there is a pronounced unconformity between the Pennsylvanian and the Permian in the Arbuckle area, and the upper Pennsylvanian strata may be absent throughout considerable districts in southern Oklahoma. The gases of these fields are therefore probably not equivalent to the Petrolia gas and may even correspond more nearly to the Strawn gas of the Ranger region.

From the foregoing description it appears that the chief factor controlling the distribution of helium in the Texas region is stratigraphic position. The only gas rich in helium occurs in beds which probably belong to the Cisco, and no gases poor in helium are known to occur in that formation; hence it appears safe to predict that whatever new supplies of gas may be discovered in the Cisco will be of value for their helium content. Furthermore, practically all the Canyon and Strawn gases contain from 0.1 to 0.4 per cent of helium, whereas gases from beds below the Strawn and also from all strata above the Cisco-Permian, Cretaceous, and Tertiary - are very poor in helium or contain none at all. The possible area in Texas in which gas carrying more than 0.5 per cent of helium occurs may therefore be considered broadly as coincident with that in which the base of the Cisco formation lies at depths between 300 and perhaps 3,000 feet; and the area of gas carrying more than 0.25 per cent includes all that in which any part of the Cisco, Canyon, and Strawn formations lies at similar depths. It is of course improbable that supplies of gas will be discovered throughout so large an area, however, and the helium-bearing district as shown in Plate III is that in which present developments indicate that gas is most likely to be discovered.

\section{APPAIACHIAN REGION.} LOCATION.

The Appalachian oil and gas region lies chiefly in the eastern parts of Ohio and Kentucky and the western parts of New York, Pennsylvania, and West Virginia. Little attention has been paid to the helium content of the gases that occur throughout this great 
area, but so far as known gas carrying more than 0.25 per cent of helium occurs only in one small district. This district is in Vinton and Hocking counties, Ohio, near the western edge of the Appalachian petroleum region.

The present extent of the Vinton and Hocking county fields is shown in generalized form on figure 5. It is possible that future development will extend these fields to the south, though for geologic reasons there is little
GEOLOGY.

In the Ohio area helium-bearing gas occurs chiefly in the Clinton sand, of Silurian age, though a small quantity of equally rich gas is found in a sand at about the horizon of the Berea, which is at or near the base of the Mississippian series. Both the Clinton and the Berea sands yield large rolumes of gas, the Clinton being productive in a belt extending northward from Vinton County through

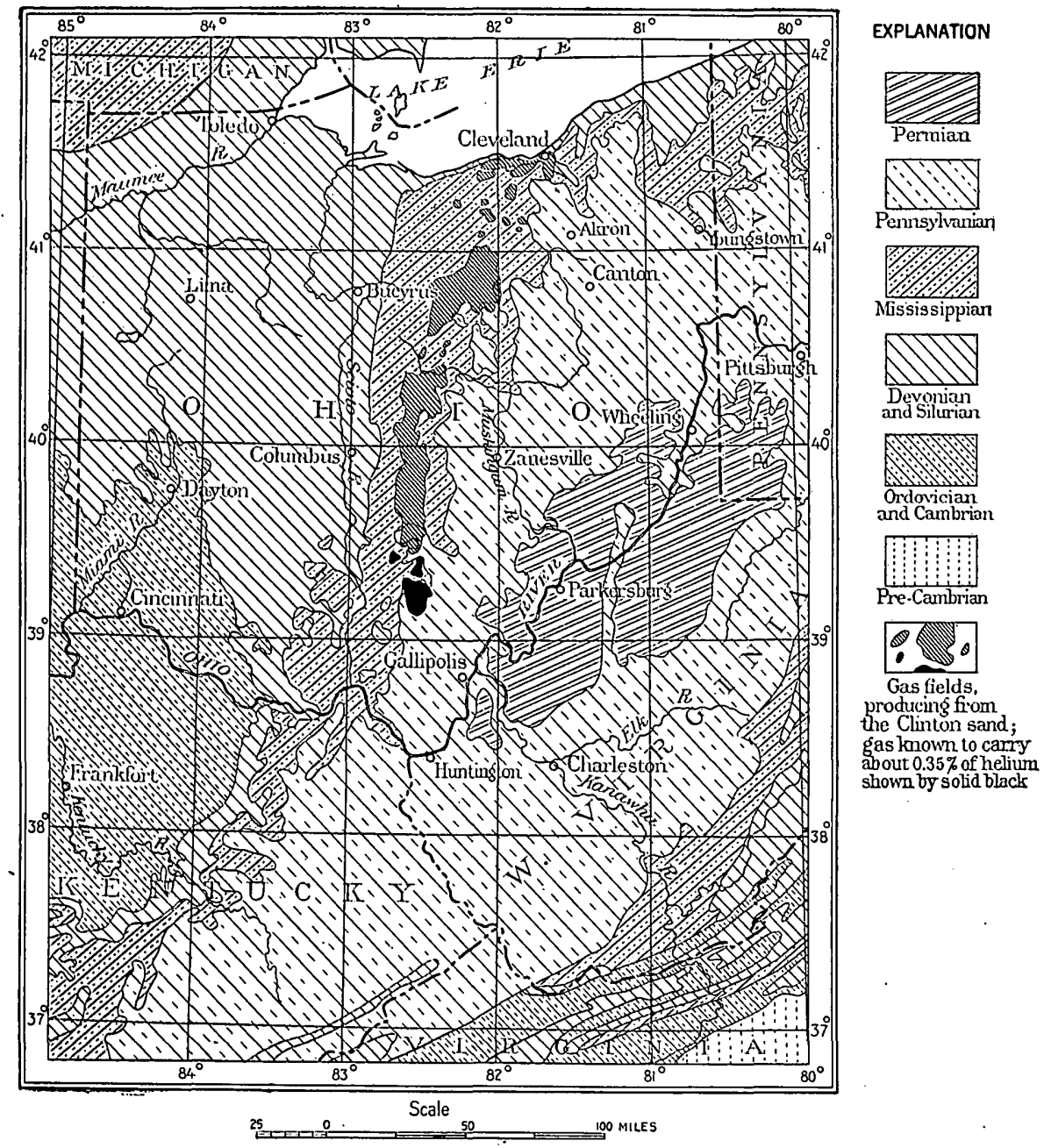

Fraure 5.-Map showing the geologic rolations of the Ohio area of helium-bearing gas

prospect of important extensions to the east or central Ohio to Cleveland and the Berea in west. The northern boundary of this helium- many fields in eastern Ohio and in Pennsylbearing area can be determined only by further vania and West Virginia; but only in Vinton sampling and analysis, but it is thought to lie and Hocking counties, Ohio, is the gas pronot far north of the fields indicated on the map. duced from these sands known to contain As the conditions controlling the distribution helium.

of helium in the Appalachian region are not The Appalachian petroleum region is in the well understood, however, it is possible that great spoon-shaped structural basin which other helium-bearing gas fields will be dis- lies between the Cincinnati anticline on the corered in entirely different parts of the region. west and the Appalachian Mountain folds on 
the east and southeñst. The general geology of the region is well brought out in figure 5 . The highest part of the broad, gentle Cincinnati anticline is defined by the outcrop of Ordovician rocks, and this is surrounded by

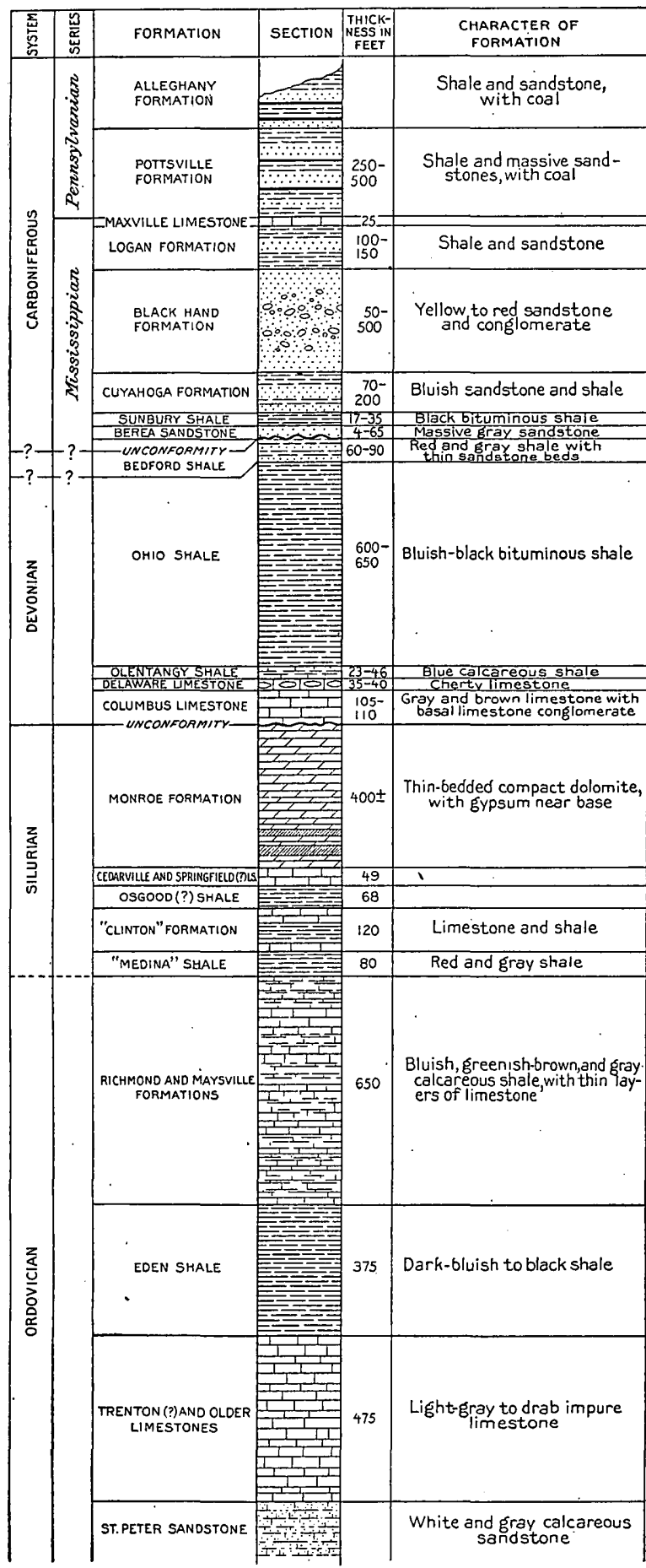

FIGURE 6.-Columnar section of rocks exposed and oncountered in drilling in south-central Ohio. Based on data given by Phalen, W.C., U.S. Geol. Survey Geol. Atlas, Kenova folio (No. 184), 1913, and by Hubbard, G. D., Stauffer, C. R., Bownocker, J. A., Prosser, C. S., and Cumings, E. R., idem, Columbus folio (No. 197), 1915. the Silurian, Devonian, Mississippian, and Pennsylvanian strata that are exposed farther down on the flanks of the anticline. The area in which Permian formations constitute the surface rocks marks the deepest part of the basin, and east of this locality the general dip of the strata is west and northwest. The dip increases sharply in the mountains, where the Mississippian and older Paleozoic formations, thrown into a series of closely compressed folds, are again exposed. Pre-Cambrian rocks crop out still farther east, in the extreme southeast corner of the area mapped.

The formations exposed and encountered in drilling in the Vinton County area range in age from Pennsylvanian to Ordovician, as shown in the columnar section (fig. 6). The surface formations are the Allegheny and Pottsville, of lower Pennsylvanian age, which consist of shale and sandstone with numerous coal beds. In Ohio the top of the Mississippian is marked by a thin limestone, but the series consists chiefly of shale and sandstone formations having an aggregate thickness of about 300 to 800 feet. The Berea sandstone, which lies at or near the base of the Mississippian, is an important reservoir of oil and gas throughout the Appalachian region. The upper and middle parts of the underlying Devonian system consist chiefly of dark shale, but the lower part is composed of two limestone formations. In the Columbus area, about 60 miles north of Vinton County, the Devonian has an aggregate thickness of 825 to 915 feet. The upper part of the Silurian system consists of limestone and dolomite formations about 450 feet thick, and the lower part, about 270 feet thick, is represented by a shale supposed to be the Osgood shale, the "Clinton" formation, and an underlying shale that represents a part of the Medina group.

The "Clinton" formation ${ }^{45}$ is of special interest because it includes the Clinton sand, the chief reservoir of natural gas in central Ohio and of helium-bearing gas in the Vinton County field. The "Clinton" formation crops out on the east flank of the Cincinnati anticline

${ }_{45}$ When gas was first discovered in these rocks at Lancaster the formation was thought to be the equivalent of the Clinton of New York. Later studies have shown that the beds lie below the true Clinton and probably belong to the Medina group. As the term Clinton sand is now too wellestablished among the drillers to be supplanted, and as no other name for the formation that contains this sand has yet been generally accepted, the term "Clinton" formation is retained in this paper in conformity with current usage. 
west of Vinton County and, dipping to the east, attains a depth of 2,000 to 2,600 feet in the Vinton County field. East of that locality the depth of the "Clinton" increases sharply, owing not only to the normal dip but to the great thickening of the Deronian shale above it, and in western Pennsylvania and West Virginia the formation lies at depths greater than 7,000 feet. The Clinton sand itself does not appear in the surface exposures of the "Clinton" formation, and drill records indicate that it feathers out and merges into shale along the western edges of the Vinton County field and of the other Clinton sand fields to the north. This thinning out of the sand has undoubtedly been the chief factor in the accumulation of natural gas throughout the belt, and most of the Clinton sand fields have monoclinal rather than true anticlinal structure.

No wells in the Vinton County district have penetrated far below the Clinton sand, but the records of deep wells near Columbus and near Waverly furnish information as to the character and thickness of the Ordovician rocks. As shown in figure 6 , the data for the lower part of which are derived from the record of a well near Columbus, the "Clinton" is underlain by more than 1,800 feet of Ordovician beds. The upper 1,000 feet of the Ordovician consists chiefly of shale, at the base of which lies 475 feet of limestone, which has been classified as Trenton (?) and older.

This is underlain by 316 feet of white sandstone that is believed to represent the St. Peter. The record of the well at Waverly, however, which is only 20 miles west of the Vinton County area, shows only 175 feet of sandstone at the horizon of the St. Peter and 320 feet of white dolomitic limestone below. According to Bassler's interpretation ${ }^{46}$ of this record, the white limestone is of Lower Ordovician age. Drillings obtained near the bottom of this well included a few firagments of a basic igneous rock which Bassler regards as probably representing the pre-Cambrian basement. If this view is correct the Clinton sand at Waverly is underlain by about 2,500 feet of sedimentary rocks, and in Vinton County the thickness of pre-" Clinton". sediments is presumably about the same.

10 Bassler, R. S., Stratigraphy of a deep well at Waverly, Ohio: $A \mathrm{~m}$. Jour. Sci., 4th ser., vol. 31, p. 19, 1911.
The only known outcrop of igneous rock in this region is near. Willard, Ky., about 85 miles south of Vinton County. The rock is kimberlite, a variety of peridotite, and appears to represent a dike that was intruded in postAllegheny time.

DISTRIBUTION OF THE HELIOM.

.The occurrence of helium in the Vinton County area was investigated by George B. Richardson, of the Geological Survey, from whose reports the following information has been taken. (See p. 90).

By far the largest supply of helium-bearing gas is found in the Clinton sand, which ranges in depth from about 2,050 to 2,450 feet and dips to the east at a fairly regular rate of 60 to 70 feet to the mile. In the eastern part of the field the sand is 20 feet or more thick, but it thins toward the west and feathers out in the western part of the county. The Clinton gas carries from 0.20 to 0.48 per cent of helium, though 14 out of the 18 samples collected showed between 0.34 and 0.44 per cent. The slight variation in helium content appears to be irregular, and no evidence of segregation, either geographic, stratigraphic, or structural, could be detected. Samples collected on the east side of the field showed as much helium as those on the west side, where the sand lies 350 feet higher.

A fact of considerable scientific interest is the occurrence of natural gas carrying practically the same proportion of helium- 0.39 per cent-in a sand at or near the horizon of the Berea, which lies about 1,850 feet stratigraphically above the Clinton sand. As pointed out in the foregoing pages, in the Mid-Continent region the gas richest in helium occurs characteristically at shallow depth, and in both the Mid-Continent and the north Texas fields the distribution of the helium-rich gases is distinctly related to the stratigraphy. The fact that the Clinton gas of Vinton County carries as much helium as the Berea gas, which is far younger and which occurs relatively close to the surface, is therefore surprising. The occurrence of helium in the Berea gas is of little practical importance in Vinton County, however, for the production from this sand is small, whereas that from the Clinton amounts to about $65,000,000$ cubic feet a day. 


\section{ROCKY MOUNTAIN AND PACIFIC COAST} REGIONS.

During the summer of 1918 practically all commercial supplies of natural gas in Wyoming, the Dakotas, Montana, Washington, and California were sampled, the Wyoming samples being collected by C. A. Fisher, consulting geologist, of Denver, Colo., and the remainder by A. W. Ambrose and E. W. Wagy, of the Bureau of Mines. The gas at Havre, Mont., proved to contain 0.27 per cent of helium; that at Pine Mountain, Wyo., about 0.26 per cent; and that at Fillmore, Calif., 0.31 per cent; but none of the other gases sampled contained more than 0.15 per cent, and the great majority contained only traces of helium or none at all. With the exception of the gas from Pine Mountain, Wyo., which is derived from a Carboniferous formation, practically all the gas produced in the Rocky Mountain and Pacific coast region is of Cretaceous or Tertiary age. This fact, taken in connection with the very low helium content of the Cretaceous and Tertiary gases of Texas and Louisiana, indicates that the prospects of discovering helium-rich gas in Cretaceous and Tertiary strata are poor.

The small Havre gas field in north-central Montana is in the southeastern part of Hill County and lies only about 30 miles south of the international boundary. The sample of Havre gas analyzed was collected from a well at the west end of the town and is presumably representative of the gas produced by the two or three other wells that have been drilled in the vicinity. The gas analyzed occurs at a depth of 1,200 to 1,300 feet, and according to Stebinger ${ }^{47}$ it is derived from the Eagle sandstone, which is the basal formation of the Montana group, of Upper Cretaceous age. The predominant surface rock in the vicinity of Havre is the Judith River formation, one of the higher formations in the same group. The Eagle is underlain by the Colorado shale, 1,500 to 1,700 feet thick, and the Colorado in turn by the Kootenai formation, of Lower Cretaceous age, 400 to 600 feet thick. On the east flank of the Bearpaw Mountains, about 30 miles southeast of Havre, the Kootenai is underlain by older Mesozoic and Paleozoic formations, but owing to the disturbed condition of the strata in this region it is impos-

${ }^{77}$ Stebinger, Eugene, Possibilities of oil and gas in north-central Montana: U. S. Geol. Survey Bull. 641, pp. 49-92,1917. sible to determine the thickness of the sediments which in the Harre district separate the Eagle sandstone from the basement rocks. The north end of the main igneous mass of the Bearpaw Mountains lies only about 10 miles south of Havre, and small isolated exposures of intrusive rock appear within 2 or 3 miles of the gas wells.

Considerable volumes of natural gas are produced in Canada, and during the war the helium content of Canadian gases was investigated. No report of this investigation has been published, but it is understood that no gases containing more than about 0.33 per cent of helium were discovered.

The gas produced in the Pine Mountain dome, 25 miles northwest of Casper, in central Wyoming, is derived from a Carboniferous formation. According to Hares ${ }^{48}$ the producing formation is probably the Tensleep sandstone, of Pennsylvanian age, though C. A. Fisher, who collected the samples, states that the gas may be derived from the overlying Embar group, which is of Pennsylvanian, Permian, and Lower Triassic age. The gas occurs at a depth of 1,668 feet. Unfortunately, the sample was lost during analysis, and the helium content was not exactly determined, but C. W. Seibel, who made the analysis, regards 0.26 per cent as a close approximation. The most interesting feature of the Pine Mountain gas is the fact that it contains more than twice as much helium as any of the other Wyoming gases tested, all of which are of Cretaceous age. A sample from the Frontier sand (Colorado group of Upper Cretaceous age), in the Buffalo Basin field, showed 0.07 per cent, and a sample from the Cloverly formation (Lower Cretaceous), in the Oregon Basin field, showed 0.09 per cent. Nine samples from these and other Cretaceous beds contained only a trace of helium, and three samples contained none. Hence, in Wyoming, as in the Mid-Continent region, the gas richest in helium appears to be of Carboniferous age. The shallow gas at Fillmore, Ventura County, Calif., is remarkable as the only one of the 56 California gases sampled that contains more than 0.15 per cent of helium. This gas, which contains 0.31 per cent of helium, occurs at a depth of about 600 feet, and

18 Hares, C. J., Anticlines in central Wyoming: U. S. Geol. Survey Bull. 641, pp. 233-280, 191i. 
according to Eldridge $e^{49}$ it is probably derived from the Sespe formation, of Oligocene(?) age. A sample from a more productive gas sand in the same field, lying at an average depth of 2,800 feet, showed, however, only 0.06 per cent of helium. A sample from the Santa Maria field, also in southern California, contained 0.13 per cent of helium, and one from the Coalinga field in Fresno County contained 0.11 per cent, but the remaining 51 samples collected from these and other fields contained only traces of helium at the most. (See pp. 96-97.)

\section{CANADA.}

A sample. of the gas produced in the Bow Island field, near Lethbridge, Alberta, about 125 miles northwest of Harre, Mont., was collected in August, 1918, by A. W. Ambrose and was found to contain 0.30 per cent of helium. At that time there were 26 gas wells in the Bow Island field having an average depth of 1,900 feet and a combined open flow of $15,000,000$ cubic feet a day. This gas is supposed to occur in the lower part of the Colorado shale, or about 1,200 to 1,500 feet below the producing sand at Havre. The fact that both these gases carry about the same proportion of helium suggests that similar gas may be found elsewhere in this region in Cretaceous formations.

\section{EUROPE.}

Systematic searches for helium - bearing natural gas in European countries were not made until after the outbreak of the European war, and the results of these explorations have not been published. Prior to the discovery of helium in Kansas natural gas by Cady and McFarland, however, a number of Italian gases of various types had been tested by Nasini, Anderlini, and Salvadori, ${ }^{50}$ and faint traces of helium had been detected in the natural gas of Bagni della Porretta, on the northern flank of the Apennines. (See p. 51.) The same investigators in 1906 identified helium in the natural gas of Salsomaggiore, ${ }^{51}$ in northern Italy, and since that time the helium

10 Eldridgo, G. H., and Arnold, Ralph, The Santa Clara Valley, Puonto Hills, and Los Angeles oil districts, southern California: U. S. Geol. Survoy Bull. 300, p. 76, 1907 .

${ }^{0}$ Nasini, R., Anderlini, F., and Salvadori, R., Ricercho sulle emanazloni torrostro italiano: Gazz. chim. ital., vol. 28, pp. 81-153, 1898.

ol Idom, vol. 36, pt. 1, p. 429, 1906. in a number of other European gases has been quantitatively determined by several chemists. Unfortunately the memoirs in which these analyses were published give little information as to the geologic occurrence of the gases, but the data given have some interest in connection with the foregoing discussion of the occurrence of helium in North American gases.

Helium was found in the gas produced at Neuengamme, near Hamburg, by Voller and Walter ${ }^{52}$ in 1910 . They found this gas, which occurs in Tertiary strata at a depth of 810 feet, to contain 5.6 per cent of nitrogen, 0.05 per cent of argon, and 0.01 to 0.02 per cent of helium. A later analysis of the same gas by Czak6 $^{53}$ showed 3.32 per cent of nitrogen and 0.0141 per cent of helium, and a test by Sieveking and Lautenschläger ${ }^{54}$ showed 0.025 per cent of helium. The last-named authors also examined gas from Transylvania, the most productive gas region in Europe, and found it to contain 0.007 per cent of helium. Gas from Kissarmás, in the same region, was found by Czakó to carry 0.0014 per cent of helium. Czakó found less than 0.01 per cent of helium in the gas produced at Wels, Austria, and in the shallow gas of the Alsatian field but reported 0.38 per cent in a small flow of gas from a deep test hole near Pechelbronn, Alsace. This gas is derived from a depth of about 3,280 feet, and the occurrence of a gas comparatively rich in helium at so great a depth is somewhat surprising in view of the apparent tendency of helium in the North American fields to collect at shallow depth. All the other European gases analyzed are believed to be of Tertiary age, however, whereas the deep Pechelbronn gas is said to issue from the Urformation, which in this locality is presumably of early Mesozoic age.

Czakó determined the radioactivity of the gases which he tested for helium and found the deep Pechelbronn gas to be very much more active than the gases poor in helium. $\mathrm{He}$ also examined a number of other natural

52 Voller, A., and Walter, B., Über den Helium und Argongehalt des Erdgases von Nenengamme: Hamburgischen wissenschaftlichen Anstàlten Jahrb., Band 28, Heft 5, 1910.

${ }^{\circ B}$ Czak6, Emerich, Über Heliumgehalt und Radioaktivität ,von Erdgasen: Zeitschr. anorg. Chemie, vol. 82, pp. 261, 268, 1913; Beiträge zur Kenntnis naturlicher Gasausströmungen, Dissertation, Grossherzoglich technischen .Hochschule zu Karlsruhe, 1913.

s4 Sieveking, H., and Lautenschläger, L., Über Helium in Thermalquellen und Erdgasen: Physikal. Zeitschr., vol. 13, p. 1043, 1912. 
gases for radioactivity and found them to be to point out the factors that seem to influence about as active as the gases known to contain its distribution in different regions. At the only very small amounts of helium. His present time only general conclusions can be results are given in the following table: drawn, however, for two neighboring wells

Helium content and radioactivity of some European natural gases.

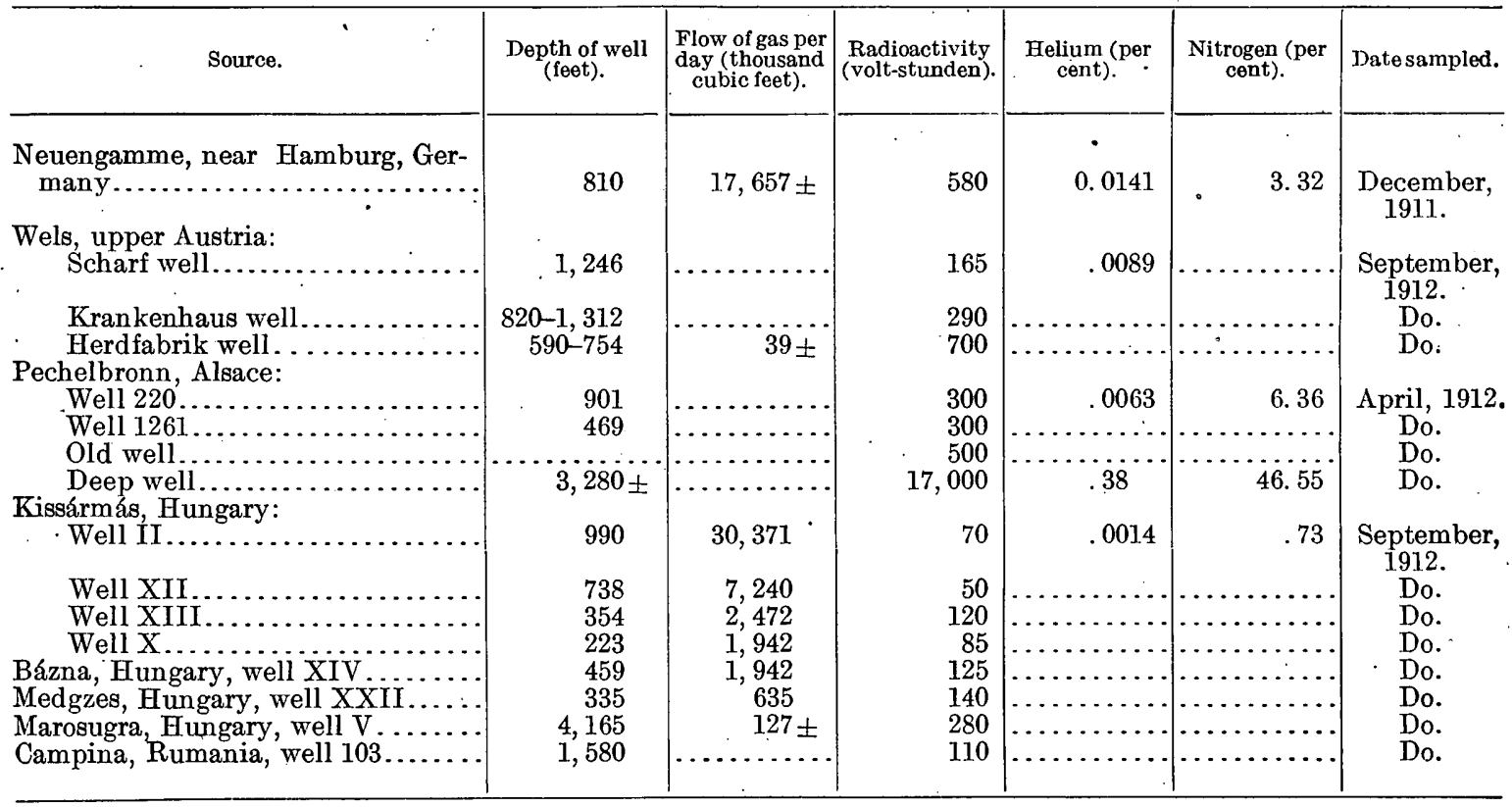

All the European natural gases that have been tested. are therefore very poor in helium with the exception of the small flow from the deep well at Pechelbronn; and if, as Czakó apparently believes, the radioactivity of a gas is a rough index of its helium content it is evident that all the other gases cited in the foregoing table are also poor in helium. As already pointed out, the Tertiary and Cretaceous gases of the United States are, with two exceptions, very poor in helium, and as practically all the European natural gases are of Tertiary age their low helium content is not surprising. It would of course be unwise to infer that all Cretaceous and Tertiary gases the world over are poor in helium, though this conclusion is suggested both by the scanty available evidence relating to helium in European gases, and by the abundant evidence regarding the distribution of helium in the United States.

\section{SUMMARY OF FACTORS INFLUENCING THE} DISTRIBUTION OF HELIUM.

In the foregoing pages the writer has endeavored to describe broadly the geologic occurrence of helium-bearing natural gas and producing from the same horizon may yield gases differing in helium content, and until the cause of such local variations is understood it is unwise to attach much significance to small differences in the helium content of gases produced in widely separated fields.

In the Mid-Continent region, which contains the largest known accumulations of heliumbearing gas, the richest gas occurs at comparatively shallow depths in upper and middle Pennsylvanian strata. In the Texas region, which is the next most prolific, the stratigraphic distribution of the gas is the same, and there is reason to believe also that rich gas will not be found at great depth. In Ohio, however, a large volume of gas carrying 0.33 per cent of helium is found in Silurian strata at a depth of more than 2,000 feet, and a small volume of equally rich gas occurs in Mississippian beds about 1,800 feet stratigraphically higher. Gas of Cretaceous and Tertiary age is usually very poor in helium, though in two localities such gas has been found to contain slightly more than 0.25 per cent.

As the helium-bearing gas in the Mid-Continent and Texas regions has a definite strati- 
graphic distribution; the boundaries of the helium-rich areas are to some extent determined by the structural and areal geology. In large part, however, these boundaries appear to be controlled by some local conditions which are not yet understood and which can be determined, if at all, only by special study. It is possible that the sediments in the heliumbearing areas are peculiar in composition, perhaps containing disseminated deposits of the radioactive minerals that generate helium. Or, it is possible that unusual structural conditions characterize the rocks beneath the heliumbearing areas and that the helium has ascended from deep-seated sources and mingled with the hydrocarbon gases formed above.

The belief that the helium is of plutonic origin is a popular one, and the writer has frequently been asked whether it is not possible to account for the helium as having arisen through fissures from great depths. Some warrant for this belief is afforded by the buried granite ridge on the west edge of the MidContinent region, which, as already described, was probably formed in part by faulting. Inasmuch, however, as the ridge extends far to the north of the helium-bearing area and probably also to the south of it, and as helium is found also many miles east of the ridge, little weight can be attached to this evidence. The practical absence of helium in the deep gases nearer the granite is a strong argument against the supposition that the helium has risen from deep-seated sources; and furthermore, there is no evidence in either the north Texas or the Ohio districts for supposing that there are any similarly unusual structural features in the basement rocks.

On the other hand, there is some evidence directly opposed to the view that helium has arisen along fissures, for the gas produced in most fields that are close to areas of uplift or to igneous intrusions is poor in helium. For example, as shown on Plate III, the fields of southern Oklahoma, which are close to the Wichita and Arbuckle uplifts, yield gas very poor in helium; and several of the Wyoming fields, which are not far from areas of uplift and intrusion, produce gas carrying only traces. The Havre field is, in fact, the only district close to an uplift which is known to produce gas carrying more than 0.25 per cent of helium. Moreover, gas produced from a depth of 730 feet beneath a Tertiary lava flow near Prosser, Wash., contains only 0.06 per cent of helium, and the gas of the Thrall field, Texas, which issues directly from a body of serpentine, contains no helium at all. The observed occurrences of the helium-bearing gas thus afford little basis for supposing that the helium is associated with unusual structure or with igneous activity.

\section{CHEMICAL COMPOSITION OF HELIUM-BEARING} NATURAL GAS.

CONSTITUENTS OF NATURAL GAS.

Although all gaseous mixtures that issue from the earth' are of course natural gases, the term natural gas is ordinarily restricted to the gaseous mixtures rich in hydrocarbons that are generally associated in nature with petroleum. In many of the old analyses of natural gas a great variety of constituents are reported, but recent improvements in the technique of gas analysis indicate that the constituents are comparatively few in number and that natural gas is sufficiently...uniform in character to warrant its recognition as a chemically distinct type. Many varieties are known, however, and between them all gradations exist.

The characteristic and principal constituents of ordinary natural gas are the light paraffin hydrocarbons, methane and ethane, with generally smaller proportions of propane and the next higher members of the paraffin series. "Dry" gas not directly associated with petroleum usually consists chiefly of methane with a little ethane; "wet" gas occurring in the same sand with oil may carry also propane, butane, pentane, and hexane. The composition of gas occurring directly with oil is, however, influenced by the decrease in pressure due to the removal of oil and gas from the sands; in the early stages of a field's life such a gas may consist chiefly of methane and ethane, but as the pressure decreases the heavier hydrocarbons, previously dissolved in the oil, are released, and the gas may then consist chiefly of propane and butane. Such gases are valuable on account of their heavier hydrocarbons, which may be extracted and condensed as gasoline; but they occur only in association with oil, and their total volume is small in comparison with that of the high-methane gases that are chiefly used for heating and lighting. Owing to the fact that the composition of "wet" or casing-head gas is 
largely a function of the pressure in the sand, such gases are not likely to carry helium in proportions large enough to be of value. Most of the gases sampled during the present investigation were therefore "dry" gases occurring in sands that do not yield oil.

Analyses made by the ordinary or eudiometric method do not show the higher hydrocarbons, which can be separated only by fractional distillation at low temperatures..$^{55}$ In the ordinary method of analysis the hydrocarbons are treated as a unit and the results are expressed, by algebraic calculation, in terms of methane and ethane alone. Nevertheless, the work of Burrell and his associates indicates that small proportions of propane and butane are present in many or most gases, though, on the other hand, it shows also that the olefin hydrocarbons which are reported in many old analyses probably do not occur in any natural gas. ${ }^{50}$ presence usually indicates contamination of the sample by air, and in such analyses the proportion of nitrogen reported is also unduly high. Hydrogen and carbon monoxide are reported, on the basis of indirect determinations, in many old analyses, but according to Burrell and Oberfell ${ }^{57}$ these. substances are really present in few if any natural hydrocarbon gases. Hydrogen sulphide is present in some gases in proportions as great as 2 or 3 per cent, though most gases do not contain even traces of it. Helium, argon, and the other inert gases are probably present in minor quantity in most natural gas, but they can be determined only by special methods, and in ordinary analyses they are reported with the nitzogen.

\section{VARIETIES OF NATURAL GAS.}

As natural gas is simply a mechanical mixture of the constituents mentioned above, it has no fixed composition and exhibits a wide $-$

Analyses showing various types of natural gas. [By Bureau of Mines.]

\begin{tabular}{|c|c|c|c|c|c|c|c|}
\hline & 1 & 2 & 3 & 4 & $\mathbf{5}$ & 6 & 7 \\
\hline 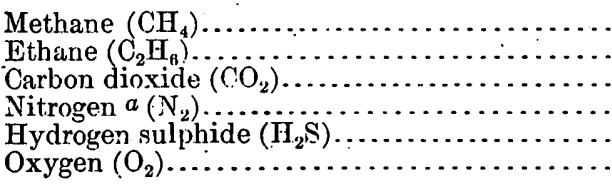 & $\begin{array}{r}86.7 \\
9.5 \\
1.7 \\
2.1 \\
\cdots .0\end{array}$ & $\begin{array}{r}96.5 \\
.0 \\
1.4 \\
2.1 \\
\cdots .0\end{array}$ & $\begin{array}{r}67.6 \\
31.3 \\
.0 \\
1.1 \\
. .0\end{array}$ & $\begin{array}{r}6.6 \\
91.1 \\
.0 \\
2.3 \\
.0\end{array}$ & $\begin{array}{r}66.2 \\
1.0 \\
30.4 \\
2.4 \\
\cdots .0\end{array}$ & $\begin{array}{r}23.6 \\
69.7 \\
2.5 \\
1.3 \\
2.9 \\
.0\end{array}$ & $\begin{array}{r}51.3 \\
10.4 \\
.1 \\
38.2 \\
.0\end{array}$ \\
\hline Heating value (British thermal units per cubic & 100.00 & 100.00 & 100.00 & 100.00 & 100.00 & 100.00 & 100.00 \\
\hline $\begin{array}{l}\text { foot, at } 0^{\circ} \text { C. and } 760 \text {-millimeter pressure) } \ldots \\
\text { Specific gravity (calculated)...................... }\end{array}$ & $\begin{array}{r}1,100 \\
0.63\end{array}$ & $\begin{array}{r}1,028 \\
0.58\end{array}$ & $\begin{array}{r}1,302 \\
0.71\end{array}$ & $\begin{array}{r}1,765 \\
0.99\end{array}$ & $\begin{array}{r}724 \\
0.85\end{array}$ & $\begin{array}{r}1,548 \\
0.91\end{array}$ & $\begin{array}{r}740 \\
0.76\end{array}$ \\
\hline
\end{tabular}

1. Fullerton field, Orange County, Calif.

$a$ Includes helium and the other inert gases.

1. Fullerton field, Orange County, Calif.

3. Oil City, Clarion County, $\mathrm{Pa}$.

4. Titusvilie, Crawford County, Pa.

5. McKittrick field, Kings County, Calif.

6. Glasgow, Barren County, Ky.

7. Petrolia field, Clay County, Tex. 2, 3, 7. Burrell, G. A., and Oberfell, G. G., Composition of the natural gas used in 25 cities: Bur. Mines Tech. Paper 109, p. 7, 1915.

Äfter the paraffin hydrocarbons the chief. range in chemical character. Several fairly constituents of natural gas are nitrogen and carbon dioxide. These substances occur in small proportion in most natural gas, but in some varieties they are important constituents. Oxygen is reported in many analyses, but its

${ }_{55}$ See Burrell, G. A., Selbert, F. M., and Robertson, I. W., Analysis of natural gas and illuminating gas by fractional distillation at low temperatures and pressures: Bur. Mines Tech. Paper 104, 1915.

so Burrell, G. A., and Oberfell, G. G., Composition of the natural gas used in 25 cities: Bur. Mines Tech. Paper 109, p. 11, 1915.

well marked varieties may be distinguished, though between them all gradations exist. The helium-rich gases, however, belong to a distinct chemical type, and in order to understand the characteristics of this type a study of the accompanying analyses, which have been selected to illustrate the different varieties of natural gas, will be helpful. 
The table on page 36 indicates that several varieties of natural gas can be distinguished, as follows:

A. Pure hydrocarbon type (analyses 1 to 4 ). Most of the natural gas produced in the United States is of this type, containing 95 per cent or more of paraffin hydrocarbons and very minor proportions of carbon dioxide and nitrogen. Many eubdivisions of the type may be made, however, according to the relative proportions of the hydrocarbons, conventionally expressed in terms of methane and ethane. Analysis 1, showing 9.5 per cent of ethane, represents the commonest variety and would not differ greatly from a composite analysis of all the natural gas produced in the United States. Analysis 2 represents a pure methane gas of the type produced chiefly in eastern Oklahoma and northwestern Louisiana. Analyses 3 and 4 presumably represent casing-head gases-gases occurring in the same sand with oil-and show high proportions of ethane and the heavier hydrocarbons. The gas represented by analysis 4 probably consists chiefly of ethane and propane, and carries butane, pentane, and hexane as well. All gas of the pure hydrocarbon type has a high heating value and is therefore the most valuable for industrial and domestic purposes.

B. Carbon dioxide type-(analysis 5). Some of the gas produced in the California fields is notable for the high proportion of carbon clioxide it contains. Some California gases carry as much as 49 per cent of carbon dioxide, and a great many contain 10 or 15 per cent. Gas of the carbon dioxide type has naturally a rather low heating value, usually less than 900 British thermal units. Swamp gases of recent origin are also usually high in carbon dioxide, but true natural gas containing noteworthy proportions of this constituent occurs almost wholly in California.

C. Hydrogen sulphide type (analysis 6). Gas carrying as much as 2 to 3 per cent of hydrogen sulphide has been found in a number of localities, though most natural gas contains no hydrogen sulphide whatever. For this reason the hydrogen sulphide gases warrant recognition as a separate type, even though their characteristic constituent is invariably present only in small proportion.

D. Nitrogen type (analysis 7 and analyses on pp. 38-40). Natural gas carrying as much as 85 per cent of nitrogen occurs in Kansas, and gas carrying from 10 to 40 per cent has been found in Oklahoma, Texas, Ohio, and elsewhere. The nitrogen type of gas is of special interest here, for it is the only one in which noteworthy proportions of helium have been found. The heating value of the nitrogen type of gas is naturally low, and gas carrying 85 per cent of nitrogen is so nearly incombustible that it is commonly called wind gas.

It is evident that ordinary natural gas may be regarded simply as the lightest member of the petroleum series-gas, oil, and asphaltand there is abundant evidence to indicate that natural gas, like oil and asphalt, is chiefly a product of the decay of organic matter that has been buried in the sediments. As there are idfferent kinds of organic matter, differing in composition, and as the conditions under which decay takes place are doubtless also variable, many different varieties of petroleum are known; and it must be recognized, furthermore, that petroleum may later undergo chemical and physical changes which lead to still further differentiation. Although the geochemistry of petroleum has not been extensively studied, it is the writer's opinion that the composition of most petroleum is determined chiefly by its geologic relations-that is, by the age and degree of deformation of the surrounding rocks and by the chemical character of those rocks and of the waters which they contain. ${ }^{58}$ There is more evidence for this thesis as applied to oil than as applied to natural gas, for gas is relatively simple in composition and to a certain extent is the end product of the decomposition of oil; yet the composition of some gases is obviously controlled by their geologic relations. Much of the carbon dioxide in the California gas, for example, has probably been formed by oxidation of the hydrocarbons through contact with mineralized waters, and the hydrogen sulphide in some gases, at least, is formed by the reduction of sulphate waters by hydrocarbons. ${ }^{50}$

The nitrogen type of natural gas, is, however, difficult to account for ${ }^{60}$ The obvious supposition that the nitrogen represents the inactive residue of air that has been entrapped. in the sediments is opposed by the fact that it contains a much smaller proportion of argon than does atmospheric nitrogen. The general occurrence of helium in highnitrogen gases also suggests that the origin of the nitrogen is in some way related to that of the helium. (See pp. 38-40.) Moreover, the nitrogen can not well be explained as due to the peculiar composition of the organic matter from which the gas was derived, for the oil of Kansas, Oklahoma, and Ohio is low in nitrogen, whereas that of California, where no highnitrogen gases are known, is exceptionally rich in the nitrogenous bases." This difference is brought out by the analyses of California, Ohio, and Kansas oils given in the following table:

68 Rogers, G. S., The Sunset-Midway oil field, Calif., Part II, Geochemical relations of the oil, gas, and water: U. S. Geol. Survey Prof. Paper $117,1919$.

69 Idem, pp. 26-29.

60 For a brief discussion of the origin of nitrogen in natural gas see Haworth, Erasmus, and MCFarland, D. F., The Dexter, Kans., nitrogen gas well: Science, new ser., vol. 21, p. 191, 1904. 
Ultimate analyses of petroleum.

\begin{tabular}{|c|c|c|c|c|c|c|}
\hline & 1 & 2 & 3 & 4 & 5 & 6 \\
\hline 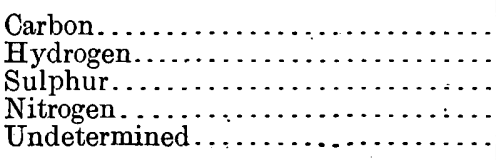 & $\begin{array}{r}84.17 \\
12.15 \\
1.50 \\
1.25 \\
\text {.. } 93\end{array}$ & $\begin{array}{r}86.51 \\
11.41 \\
.74 \\
.58 \\
.76\end{array}$ & $\begin{array}{r}84.57 \\
13.62 \\
.72 \\
.11 \\
.98\end{array}$ & $\begin{array}{r}85.46 \\
13.91 \\
.48 \\
.15\end{array}$ & $\begin{array}{r}85.43 \\
13.07 \\
.37 \\
\quad \text { 1. } 13\end{array}$ & $\begin{array}{r}85.63 \\
12.44 \\
.37 \\
1.56\end{array}$ \\
\hline & 100.00 & 100.00 & 100.00 & 100.00 & 100.00 & 100.00 \\
\hline
\end{tabular}

1. Bardsdale, Calif. Mabery, C. F.; and Hudson, E. J., On the composition of California petroleum: Am. Acad. Arts and Sci. Proc., vol. 36, p. 255. 1900 . Mcttrick, Calif. Allen, I. C., and Jacobs, W. S., Physical and chemical properties of the petroleums of the San Joaquin Valley, Calif.: Bur. Mines Bull, 19, p. 28, 1911 .

3. Findlay, Ohio. Mabery, C. F., On the composition of the Ohio and Canadian sulphur petroleums: Am. Chem. Jour., vol. 17, p. 727, 1895. 4. Welker, Ohio. Mabery, C. F., idem.

5. Cherryvale, Kans. Bartow, Ėdward, and McCollum, E. V., Kansas petroleum: Kansas Acad. Sci. Trans., vol. 19, p. 58, 1903.

6. Humboldt, Kans. Bartow, Edward, and McCollum, E. v.,'idem.

COMPOSITION OF HELIUM-BEARING GAS.

As stated in the foregoing sections, although at least traces of helium occur in most natural gas, noteworthy proportions have been found only in gas of the nitrogen type. The percentage of helium, moreover, seems to depend in a measure on the percentage of nitrogen, though there is no direct proportionality between the two, and the nitrogen-helium ratio varies greatly in different gases. On the other hand, there are some natural gases high in nitrogen which carry only small proportions of helium. The chemical characteristics of helium-bearing gas are shown by analyses 1 to 16 , on page 39 .

In the course of the present investigation the helium content of a large number of gases was determined(see pp. 96-109), but only a few complete analyses were made. Those given in the first table(p. 39)were therefore selected from the analyses, mostly of Kansas gas, published by Cady and McFarland. ${ }^{61}$ In the second table are given a few ordinary analyses of gas from other localities, together with determinations of the helium content of gas from the same. source. Samples for the ordinary analysis and for the helium determination of the Ohio gases, Nos. 23 and 24, were collected simultaneously, but the samples for the ordinary analyses of the other gases were collected several months or years before those for the helium determinations. As natural gas from the same well varies somewhat in composition from day to day, the exact ratio between helium and nitrogen in these samples can not be determined

${ }^{61}$ Cady, H. P., and McFarland, D. F., The composition of natural gas, with special study of the constituents of Kansas gases: Kansas Univ. Geol. Survey, vol. 9, pp. 228-302, 1908 . from the data given, though the ratios indicated are undoubtedly approximately correct. More extensive data regarding the ratio of helium to nitrogen are given in figure 7 ( $p$ 40), which is based on all the analyses given by Cady and McFarland and on a few composite determinations similar to those in the accompanying table. As such determinations do not furnish data for computing the exact ratio they are plotted in the diagram as large open circles, whereas complete analyses on one sample are plotted as small dots.

The diagram brings out the wide variation in the ratio of helium to nitrogen in different gases but indicates that the average gas containing 10 per cent of nitrogen carries about 0.3 per cent of helium and that no gas containing 10 per cent of nitrogen is likely to carry more than 0.5 per cent of helium. Exceptions to this rule may be found, but the principle is believed to be sufficiently well founded to warrant the use of the nitrogen determination as a guide to the detection of helium-bearing gas; and in the writer's investigation of the distribution of helium a large number of ordinary analyses were collected and were used to supplement the data afforded by the direct tests for helium. Moreover, nitrogen is the chief factor in lowering the heating value of the Mid-Continent gases, and as general information concerning the heating value of a gas is usually not difficult to obtain, the rule that gases low in nitrogen are poor in helium is of great practical aid in locating the helium-rich varieties.

It should be noted, however, that gases low in heating value are not necessarily rich in helium. In the first place, low heating value may be due, as in.California gas, to a high per- 
Analyses of helium-bearing natural gas.

[By Cady and McFarland.]

\begin{tabular}{|c|c|c|c|c|c|c|c|c|}
\hline & 1 & 2 & 3 & 4 & 5 & 6 & 7 & 8 \\
\hline \multirow[t]{3}{*}{ 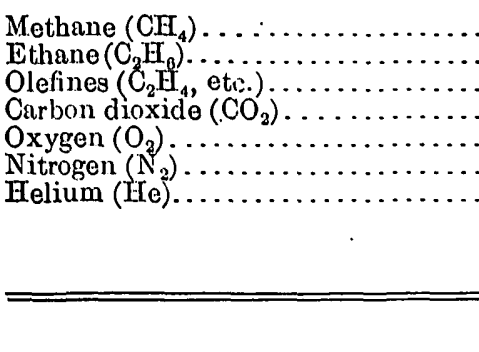 } & $\begin{array}{r}14.85 \\
.41 \\
\ldots .00 \\
.00 \\
.20 \\
82.70 \\
1.84\end{array}$ & $\begin{array}{r}51.80 \\
.00 \\
.00 \\
.20 \\
.10 \\
46.40 \\
1.50\end{array}$ & $\begin{array}{r}82.25 \\
.00 \\
.12 \\
.61 \\
\text { Trace. } \\
16.40 \\
.616\end{array}$ & $\begin{array}{r}78.60 \\
7.71 \\
.55 \\
.15 \\
.30 \\
12.13 \\
.56\end{array}$ & $\begin{array}{r}74.10 \\
.00 \\
7.04 \\
.00 \\
24.85 \\
.51\end{array}$ & $\begin{array}{r}81.40 \\
.00 \\
.00 \\
.92 \\
\text { Trace. } \\
17.22 \\
.46\end{array}$ & $\begin{array}{r}84.40 \\
.00 \\
.10 \\
.00 \\
\text { Trace. } \\
15.10 \\
.40\end{array}$ & $\begin{array}{r}88.60 \\
.00 \\
.00 \\
.62 \\
.31 \\
10.20 \\
.27\end{array}$ \\
\hline & 100.00 & 100.00 & 99.996 & 100.00 & 100.00 . & 100.00 & 100.00 & 100.00 \\
\hline & 9 & 10 & 11 & 12 & 13 & 14 & 15 & 16 \\
\hline \multirow[t]{2}{*}{ 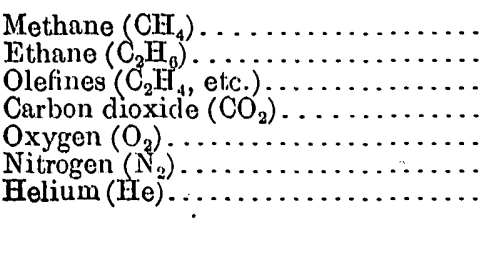 } & $\begin{array}{r}79.10 \\
7.44 \\
.77 \\
.00 \\
.00 \\
12.44 \\
.25\end{array}$ & $\begin{array}{r}94.50 \\
.00 \\
.00 \\
.00 \\
.23 \\
5.08 \\
.183\end{array}$ & $\begin{array}{r}94.30 \\
.75 \\
.00 \\
1.94 \\
.24 \\
2.60 \\
.17\end{array}$ & $\begin{array}{r}81.10 \\
11.95 \\
.10 \\
.10 \\
.20 \\
6.39 \\
. .159\end{array}$ & $\begin{array}{r}92.40 \\
.00 \\
.10 \\
.81 \\
.15 \\
6.43 \\
.08\end{array}$ & $\begin{array}{r}77.40 \\
14.18 \\
.86 \\
.73 \\
.00 \\
6.66 \\
.167\end{array}$ & $\begin{array}{r}88.10 \\
7.37 \\
.65 \\
.24 \\
.00 \\
3.60 \\
.09\end{array}$ & $\begin{array}{r}86.50 \\
.00 \\
.29 \\
1.35 \\
.00 \\
11.86 \\
\text { Trace. }\end{array}$ \\
\hline & 100.00 & 99.993 & 100.00 & 99.999 & 99.97 & 99.997 & $a 100.00$ & 100.00 \\
\hline
\end{tabular}

a Includes 0.25 per cent reported as hydrogen.

1. Doxter, Cowlcy County, Kans. Gas from 310-foot well supplying town. Collected in 1905.

2. IEreka, Grecnwood County, Kans. Gas from wells drilled in northeast cormer of town and furnishing town supply. A verago depth of 3. Frodonia, Wilson County, Kans. Pipo-lino sample of gas used in Fredonia and furnished by wells 1,085 to 1,250 feet deep, 2 to $7 \mathrm{miles}$ east, south, and northwost of town.

4. Elm dalo Chaso County, Kans. Gas from wells about 150 feet deep. Collected Octoher 6,1906 .

5. Molino, Elk County, Kans. Gas from wells about 1,150 fect deep south, cast, and west of Moline. Collected June 24, 1906.

6. Lawrenco, Douglas County, Kans. Sample of small flow of gas escaping from abandoned well about 1,200 feet deep. Collected July 4,1905. 7. Olathe, Johnson County, Kans. Sample of gas supplied to town and derived from wells near Spring Hill, about 10 miles to the south.

Average dopth of wells 580 feet. Collectod August 2, 1905

8. Eudora, Douglas County, Kans. Gas from wells about 350 fect deep.

9. Augusta, Butier County, Kans. Gas from wells averaging 1,440 feet in depth. Sampled August 4, 1906.

1. Iola Allon County Kans. Sample of ges supplied

11. Pipo-lino samplo of gas supplied to town of Lawronce, Kans., and derived chiefly from fields in Allen and Neosho counties. Collected

Docember 12,1906

12. Arkansas City, Cowloy County, Kans. Gas from well 750 feet doep.

13. Caney, Montgomory County, Kans. Gas from well 1,550 feet deep, 2 miles east of Caney. Collected July 14, 1906.

15. Morgantown, Monongalin County, W. Va. Sample from well about 1,800 feet deep, 10 miles west of Morgantown. Producing sand probably Big Injun. Sampled August 18, 1906

16. Plerro, Itughos County, S. Dak. Gas from shallow wells.

Analyses of helium-bearing natural gas.

[Eudiomotric analyses by various chemists; helium later determined on different samples from same source by C. W. Seibel.]

\begin{tabular}{|c|c|c|c|c|c|c|c|c|}
\hline & 17 & 18 & 19 & 20 & 21 & 22 & 23 & 24 \\
\hline 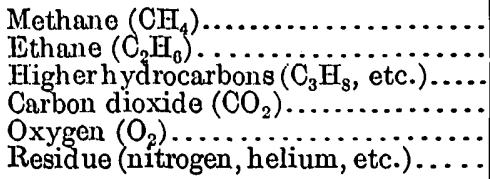 & $\begin{array}{r}10.54 \\
1.64 \\
.00 \\
.13 \\
.00 \\
87.69\end{array}$ & $\begin{array}{r}38.94 \\
4.80 \\
.00 \\
.24 \\
.32 \\
55.70\end{array}$ & $\begin{array}{r}50.6 \\
10.9 \\
\cdots \cdots \\
.1 \\
38.4\end{array}$ & $\begin{array}{r}49.08 \\
3.89 \\
.00 \\
.40 \\
.00 \\
46.67\end{array}$ & $\begin{array}{r}30.33 \\
26.69 \\
.00 \\
.49 \\
.00 \\
42.51\end{array}$ & $\begin{array}{r}57.89 \\
16.89 \\
.00 \\
.24 \\
.00 \\
24.97\end{array}$ & $\begin{array}{r}77.3 \\
7.6 \\
\cdots \\
.0 \\
.0 \\
15.1\end{array}$ & $\begin{array}{r}86.1 \\
4.6 \\
.0 \\
.0 \\
9.6\end{array}$ \\
\hline
\end{tabular}

17. Augusta flold, Butler County, Kans. "Wind gas" occurring at depth of 400 to 600 feet." Analysis by H. C. Allen, University of Kansas." 17. Augusta fold, Butler County, Kans. "Wind gas" occurring at depth of 400 to 600 feet. Analysis by H. C. Allen, University of Kansas.
18. Sedan district, Chautauqua County, Kans. Gas from Fleming \& Wadsworth well, sec. 27 , T. $33 \mathrm{~S}$., R. $11 \mathrm{E}$. Depth 375 feet. . Analysis by 1.: C. Allen. on sampotrolia fleld, Clay County, Tex.

20. Sedan district, Rogers pool, Chautauqua County, Kans. Gas from T. E. Barr well 1, sec. 36, T. 33 S., R. 10 E. Depth about 690 feet. Analysis by H. C. Allen. Billings field, Noblo County, Okla. Gas from E. N. Gillespie gas well, sec. 21, T. 23 N., R. 2 W. Depth of sand 1,036 feet. Analysis by

Empire Gas \& Fuel Co.

22. Morrison fleld, Pawnee County, Okla. Gas from Miller well 1. Analysis by Empire Gas \& Fuel Co.

23. Vinton County fleld, Ohio. Gas from Ohio Fuel Supply Co.'s well 1991, sec. 1, T. 9 N., R. 18 W. Gas from Clinton sand at 2,49s foet.

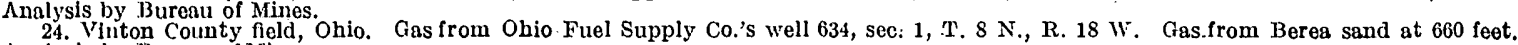
Analysis by Bureau of Mines. 
centage of carbon dioxide. Secondly, even if it lower ratios are in the gases of central Kansas is due to nitrogen a high percentage of nitrogen fields, which lie near the north end of the does not necessarily indicate a gas rich in area. It seems, however, that the gases in helium. Some of the northern Oklahoma gases which the ratio is unusually low are rather carry from 20 to 40 per cent of nitrogen and only 1 poor in both helium and nitrogen.

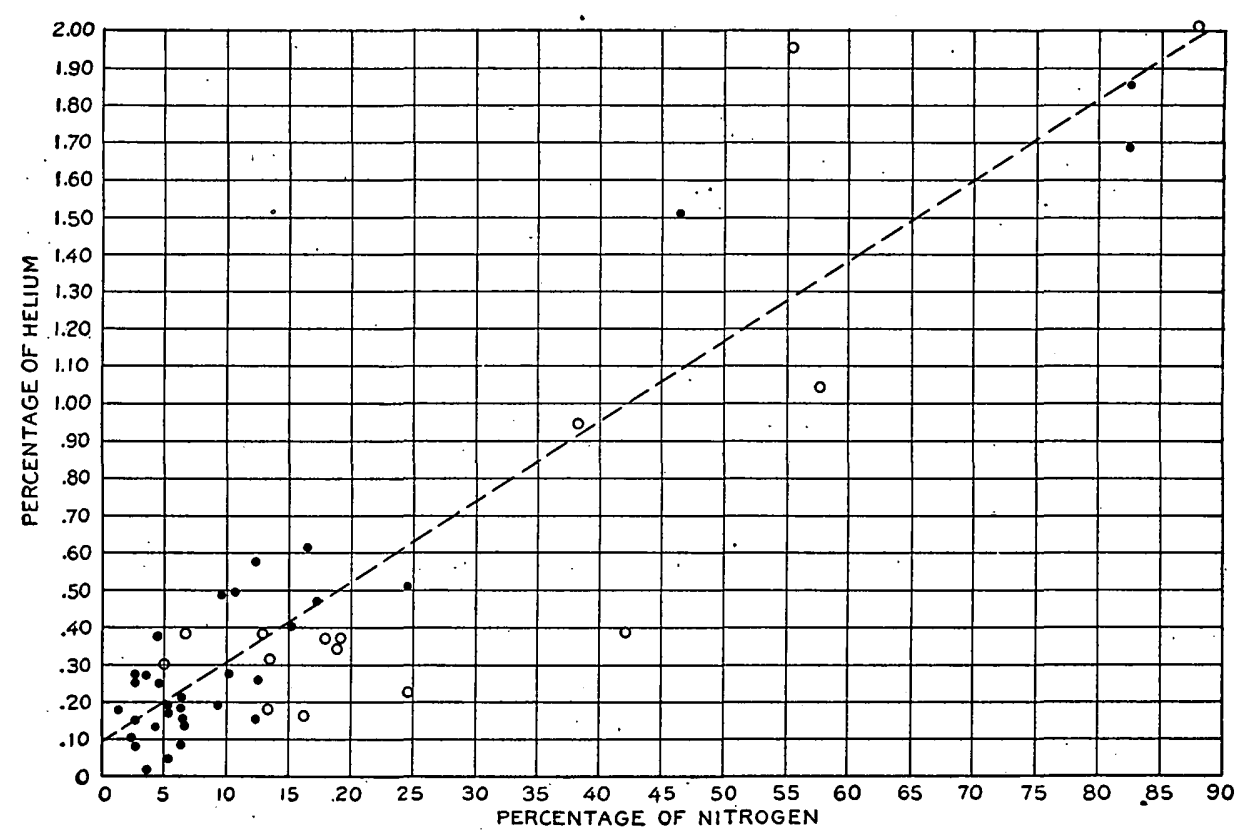

FIGURE 7.-Diagram showing relation of helium to nitrogen in 50 samples of natural gas. Points based on complete analyses of one sample indicated by dots; points based on determinations of helium in one sample and of nitrogen in another indicated by open circles.

0.2 to 0.4 per cent of helium. The range in the ratio of nitrogen to helium in a few typical gases is shown in the following table:

Ratios of nitrogen to helium in natural gas.

\begin{tabular}{|c|c|c|c|}
\hline Field. & $\begin{array}{c}\text { Nitro- } \\
\left.\text { gen ( } \mathrm{N}_{2}\right) \\
\text { (per } \\
\text { cent). }\end{array}$ & $\begin{array}{c}\text { Helium } \\
(\text { He) } \\
\text { (per } \\
\text { cent). }\end{array}$ & $\begin{array}{l}\text { Ratio } \\
\mathrm{N}_{2} \mathrm{He} \text {. }\end{array}$ \\
\hline 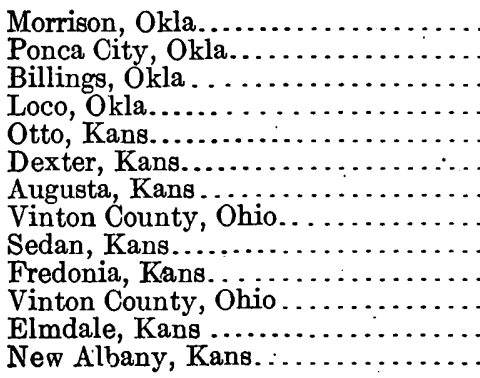 & $\begin{array}{r}25.0 \\
40.1 \\
42.5 \\
16.2 \\
57.8 \\
82.7 \\
88.0 \\
15.1 \\
55.7 \\
16.4 \\
9.6 \\
12.1 \\
9.8\end{array}$ & $\begin{array}{r}0.22 \\
.36 \\
.39 \\
.17 \\
1.04 \\
1.84 \\
2.00 \\
.43 \\
1.94 \\
.62 \\
.40 \\
.56 \\
.49\end{array}$ & $\begin{array}{r}114 \\
111 \\
109 \\
95 \\
55 \\
45 \\
44 \\
35 \\
29 \\
26 \\
24 \\
22 \\
20 .\end{array}$ \\
\hline
\end{tabular}

It is conspicuous that the highest ratios are found in northern Oklahoma, in gases such as those of the Ponca City, Billings, Morrison, Pearson, and Myers fields, all of which lie near the southern extremity of the rich heliumbearing area. On the other hand, some of the
DETERMINATION OF HELIUM IN NATURAL GAS. DEVELOPMENT OF METHODS.

Identification of the presence of helium in most gaseous mixtures is accomplished without great difficulty by means of the spectroscope, provided the proportion of helium present is not too small. The precise quantitative determination of the helium, however, requires its separation from the other gases composing the mixture, and this is a more difficult matter. Carbon dioxide, oxygen, and the hydrocarbons are easily. eliminated, but special methods are necessary for the removal of nitrogen and the inert gases.

Ramsay in his early researches on helium removed the nitrogen by sparking, which is a slow and tedious process. Sparking under various conditions was at first used by other investigators, but Dewar's discovery that nitrogen is absorbed by charcoal cooled with liquid air, whereas helium is not, has served to facilitate greatly the separation of the two elements. Dewar's principle is now generally used by most English and American investigators, although some French scientists prefer the 
more laborious chemical methods of removing nitrogen.

Cady and McFarland in their original research on helium in natural gas adopted Dewar's principle to remove nitrogen and all the other common constituents of the gas and constructed an apparatus in which the whole operation could be efficiently conducted. Essentially the same method, with a similar apparatus, was used by Prof. Cady at the outset of the Government's investigation and also by C. W. Seibel in his continuation of the work. The method is one of unusual interest because of the short time required for accurate determinations, and Mr. Seibel, who analyzed most of the samples discussed in this report, has courteously furnished the following description of it:

\section{APPARATUS AND METHOD OF PROCEDURE.}

$$
\text { By C. W. SEIBEL. }
$$

The apparatus used in the quantitative determination of helium from either natural gas or concentrates was essentially the same as that employed by Cady 'and McFarland in their earlier work. ${ }^{62}$ It is not so well known, however, as to preclude description here. The method of analysis also was similar to that of the original work, but modifications have been added from time to time, by Dr. Cady and his coworkers, and these have been included in the following account.

The apparatus, which is shown in Plate IV, is composed of the following parts: $F$ is an automatic single-fall Sprengel vacuum pump, of the ordinary 4-tube type. The tubes are about 83 centimeters long and 6 millimeters in outer diameter except the capillary fall tube, which is a heavy capillary tube $1 \frac{1}{2}$ millimeters in inner diameter and 110 centimeters long and the free end of which is bent upward so as to deliver into the collecting bulb $j$. This bulb is of 50 cubic centimeters capacity and has a capillary stopcock on the top. The bulb $g$ is an air trap, the top of which is sealed after the pump is filled with mercury. The four pump tubes are joined together at the bottom with heavy-walled stethoscope tubing. Screw clamps here serve very well to regulate the speed of the pump. The mercury is pumped from the main reservoir $m$ to the pump supply reservoir $h$ through $k$ and $k_{1}$ by means of an auxiliary Nelson vacuum pump $u$, attached to the supply reservoir at $i$. A few iron wires inserted into the end of the suction pipe at $k$ cause alternate slugs of mercury and air to be drawn up $k$ and $k_{1}$ and into $h$. By means of a cork float to which $k$ is fastened; any level of mercury desired can be maintained in the supply reservoir. $l$ is the mercury. overflow outlet of the supply reservoir, the excess mercury flowing down the tube which dips below the mercury in trap $l_{1}$. This trap prevents the loss of the vacuum in $h$. $d$ and $e$ are mercury and water vapor traps and, being of small tubing, are 80 arranged that they go into one Dewar tube, which

Am. Chom. Soc. Jour., vol. 29, p. 1522, 1907. affords considerable saving in liquid air and space. During the analysis these tubes are immersed in liquid air and serve to prevent water vapor or mercury vapor from entering the spectrum tube. The spectrum tube $c$ is so constructed that the light for the spectroscope may be taken either from the end of the capillary or along it. It is excited by a 6-volt spark coil giving a spark of about 1 centimeter in air. The gas, having stood over charcoal at the temperature of liquid air and passing through this tube excited by the spark coil, emits a glow which when viewed through the spectroscope tells at a glance whether or not the gas is pure or contaminated with nitrogen. Any appreciable amount of nitrogen can be told by the color of the tube alone, for nitrogen will cause the spectral tube to give a purplish glow, while pure helium unless at very low pressure is yellow. The bulbs $b_{1}, b_{2}$, and $b_{3}$ are made of glass carefully annealed. They contain about 20 grams of coconut charcoal each, with plugs of glass wool at either end, and are of such dimensions that they will easily fit in 40 by 200 millimeter Dewar tubes. They are connected with one another by being sealed in such a manner as to make one continuous train. Three-way glass stopcocks are inserted in the train in such wise that tubes $b_{1}$ and $b_{2}$ may be used in series, and $b_{3}$ may be in series with the other two or by-passed at will. These stopcocks are also arranged in such a manner that the three charcoal tubes can be conveniently exhausted by the auxiliary pump. $a_{2}$ is a glass liquefaction bulb of 40-cubic centimeter capacity with a mercury manometer, $a_{3}$, attached. By means of this manometer the pressure in $a_{2}$ can be determined at any time. The liquefaction bulb is so constructed that the gas must go nearly to the bottom of the tube before it can get into the connecting tube between $a_{2}$ and $b_{1}$. The curlicues inserted into different parts of the apparatus serve as expansion joints. The two tubulated bottles $p$ and $q$ are used for measuring gas samples and are of 2-liter capacity. They are so arranged that $p$ can be filled with water which has been saturated with helium, and then the water displaced by natural gas, the water going into $q$ and vice versa. After the bottles are leveled up a pinch clamp on the connecting tube between the two serves to maintain atmospheric pressure in $p$, and a pinch clamp on the inlet tube to prevent the escape of gas while weighing, etc. $o$ is a solution balance for weighing $p$ and should have a sensibility of $1 \mathrm{gram}, \quad v$ is a cylinder for collecting samples from the field. $n$ is an electric heater for heating the charcoal bulbs while they are being exhausted. $u$ is a Nelson two-stage vacuum pump for exhausting the charcoal bulbs while being heated, and for use as an auxiliary vacuum pump to lift the mercury into the supply reservoir $h$. The switches $r, s$, and : control the spark coil for the spectrum tube, motor for vacuum pump, and heater, respectively.

The apparatus is first evacuated - the charcoal bulbs by the Nelson pump and the spectrum tube and traps by the mercury puinp to a black vacuum. The charcoal bulbs are heated to $200^{\circ} \mathrm{C}$. and the evacuation is continued for about 20 minutes. After being allowed to cool, the charcoal bulbs, liquefaction bulh, and water and mercury vapor trap are immersed in liquid air, which is contained in silvered Dewar tubes. While the charcoal bulbs are cooling, the gas, which is held in the sampling cylinder 
under a pressure of several pounds, is forced into the tubulated measuring flask. A pinch clamp is put on the end of the inlet tube, the bottles are leveled, a pinch clamp is placed on the connecting tube, and the flask $p$ is weighed on the solution balance. A portion of this gas, approximately 1 liter, is then allowed to flow from the bottle through the rubber tube to the evacuated space of the liquefaction bulb, the flow being controlled by stopcock $a_{1}$, and the rate of inlet being determined by the action of the manometer. At the temperature of liquid air the hydrocarbons are liquefied, and the pressure on the manometer adjoining indicates whether or not the gas is of high nitrogen content. If the nitrogen content is high the manometer will indicate considerable pressure within the tube, which can be due only to unliquefied nitrogen or helium, though of course a small amount of it is always due to the partial pressure of methane and other hydrocarbons. The unliquefed portiun, consisting of nitrogen, helium, and some of the hydrocarbons, is admitted, in small amounts, to the first charcoal bulb, which of course is under a very high vacuum, and then to the second. This procedure is repeated until the manometer will rise no farther, indicating that all the helium and nitrogen and some methane have gone into the charcoal bulb and that the pressure in the liquefaction bulb is due only to methane and the higher hydrocarbons. The gas is allowed to stand in the charcoal bulbs for about three minutes, and then communication is made. between the charcoal bulb, the spectrum tibe, and the pump. The gas not adsorbed by the charcoal is pumped off and delivered into the collecting tube $j . A s$ coconut charcoal at the temperature of liquid air will absorb relatively large volumes of all gases except helium, neon, and hydrogen, and as neon and hydrogen do not occur in troublesome quantities, the gas delivered by the punp should be pure helium. However, to aroid danger of the charcoal bulbs becoming supersaturated with nitrogen or the possibility of an air leak developing, so that nitrogen would be pumped off with the helium, constant watch is kept of the spectrum tube by means of a spectroscope, small amounts of nitrogen being very easily detected in this way. If nitrogen appears early enough, the pump is stopped, the third charcoal bulb, $b_{3}$, is put into communication with the punip, and the nitrogen diffuses back into it, and then by pumping the helium, which is in $b_{1}$ and $b_{2}$, through $b_{3}$, a satisfactory determination can often be obtained without having to repeat the entire experiment.

If the spectroscope indicates nothing but helium, the pumping is continued until the spectrum tube shows cathode rays or goes out. The gas which has been collected in $j$ at the bottom of the mercury pump is transferred to a sinall IIempel burette, and its volume is determined. After the tubulated flasks are releveled, the one containing gas is again weighed. The difference in weight, in grams, of the flask as first weighed full of gas and after part of the gas has been used and has been displaced with water gives the volume of gas used in cubic centimeters. If care is taken to see that the bottles are carefully leveled and stand always in the same relative position while being weighed, the necessary accuracy in measuring the volume of the natural-gas sample used may be easily obtained. All volumes are reduced to standard condition and the percentage of helium is calculated.
'This method, though somewhat long, taking on an average of about $1 \frac{1}{2}$ hours for a determination, in the hands of one who is familiar with it gives surprisingly good results, repeated checks within 0.02 per cent being easily obtained.

For a satisfactory apparatus a good deal depends on the stopcocks used and the lubricant employed. A stopcock should be of the best quality obtainable, and the best lubricant has been found to be that as given in Ramsay and Travers's hook "Experimental study of gases," namely, two parts of pure rubber clippings to one part of vaseline and one-eighth part of hard paraffin wax heated until a homogeneous mixture is obtained. A good stopcock, when properly lubricated, will appear perfectly clear, showing no rings or air bells whatever.

The writer wishes to take this opportunity to express his appreciation for the help and advice afforded him by Dr. H. P. Cady, under whose personal direction the early part of the work was performed, and by Dr. R. B. Moore, at Fort Worth, during the later part of the work; also for the assistance of Messrs. H. M. Eastman and J. B. Ramsay, who analyzed some of the samples toward the end of the field work, and to Miss Emily V. Burger, of the University of Kansas, who analyzed 13 samples while the writer was on a trip to the Fort Worth plants.

\section{OCCURRENCE OF HELIUM IN MINERALS AND IN OTHER GASES.}

GENERAL DISTRIBUTION OF HELIUM.

Although helium was discovered on the earth only 25 years ago and for some time thereafter was regarded as one of the rare elements, it is now known to be widely distributed through the earth's crust. As already described, helium was discovered on the earth in the gas given off by uraninite, and the researches of Strutt and others have shown that a great variety of other minerals and rocks contain helium in small proportions. Only a few months after its discovery helium was found to be a constituent of the atmosphere and of the gas given off by a mineral spring, and it has since been found to occur in the gases emitted by a great many other springs. Helium has been found also in mine gases and in volcanic gases, as well as in natural gas.

The discovery in 1903 of the fact that helium is a product of the decay of the radio-elements, which were known to be widely disseminated, furnished to most observers an adequate explanation of the occurrence of helium in so many natural substances. There is no doubt that the minute proportions of helium found in most minerals may be accounted for in this way, but the great volumes found in natural gas are more difficult to explain. Before discussing the origin of helium in natural gas it 


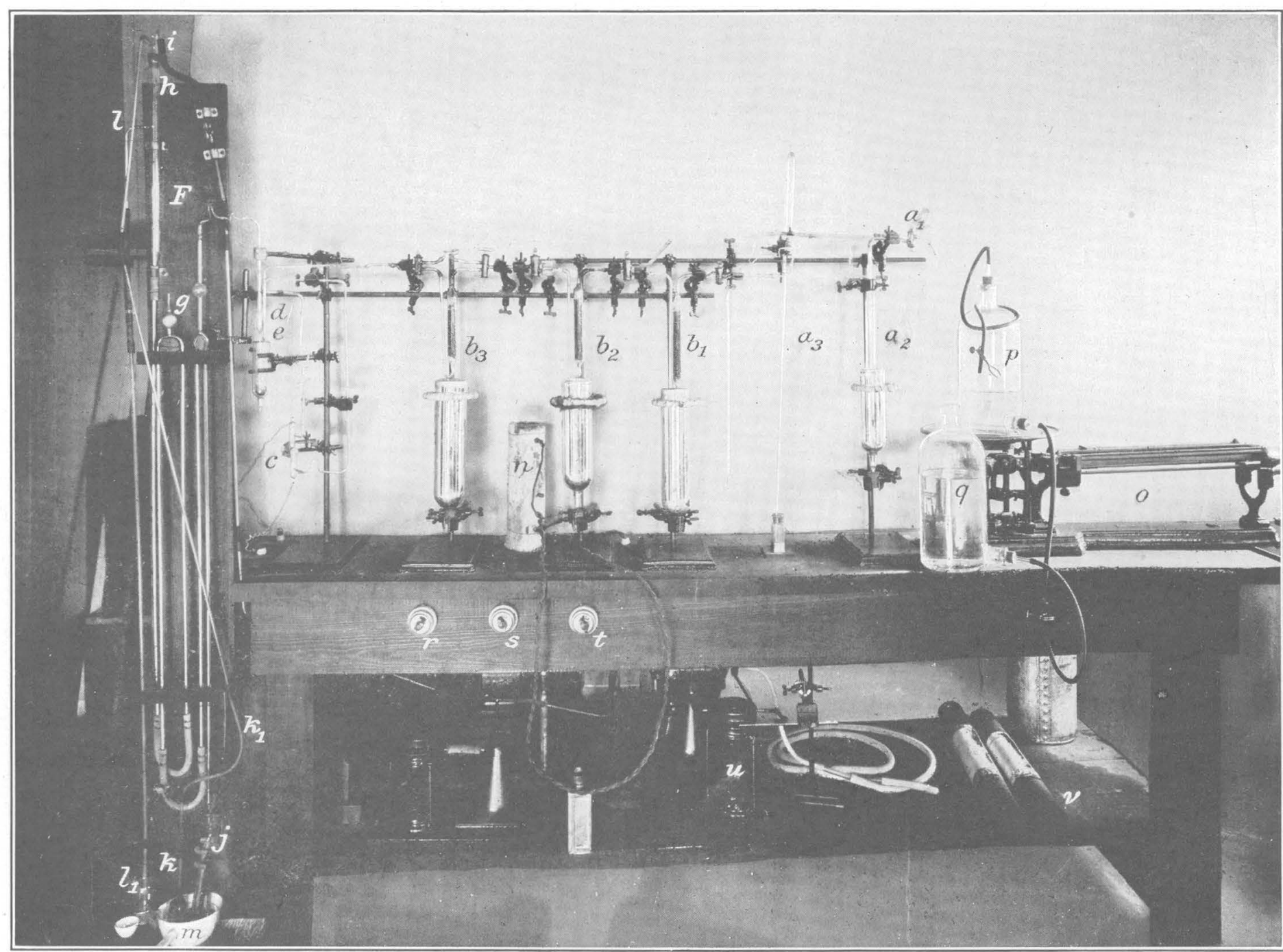

APPARATUS USED IN QUANTITATIVE DETERMINATION OF HELIUM 
will therefore be desirable to review the occurrences of helium in minerals and in other gases.

\section{HELIOM IN MINERALS AND ROCKS.}

HELIUM CONTENT OF MINERALS.

The discovery of helium in uraninite naturally led to a search for it in other minerals, with the result that only a year or so after the element itself was discovered a number of minerals were found to be helium bearing. When the relations of helium to the radio-elements became known, a great many more minerals were tested, the amounts of helium and of radium and thorium in each being determined quantitatively, so that extensive data on the distribution of helium in minerals are now available. A very great majority of all the minerals tested have proved to contain at least traces of helium, the proportion varying in general with the proportions of the radio-elements. Some minerals that contain no radioactive substances, however, have been found to contain helium in considerable quantities.

The first observations on the occurrence of helium in minerals were made by Ramsay and Travers $^{\text {i3 }}$ in 1897. They found that the rareearth minerals fergusonite, monazite, samarskite, columbite, pitchblende, and malacone contain helium "up to 1.5 cubic centimeters per gram." The malacone contains argon as well. ${ }^{\circ}$ Specimens of cinnabar, cryolite, apatite, barite, scapolite, and cobalt ore gave no helium or argon. Five meteorites were tested with negative results, but the meteorite from Augusta County, Va., proved to contain helium.

Chamberlin, ${ }^{65}$ in connection with his studies of the gases in rocks, determined the composition of the gases given off by heating pitchblende and carnotite in a vacuum as follows:

03 Ramsay, William, and Travers, M. W., The gaseous constituents of cortain mineral substances and waters: Roy. Soc. London Proc., vol. 60, p. 442, 1897.

o4 Kitchin, E. S., and Winterson, W. G., Malacone, a silicato of zir: conium containing argon and helium: Chem. Soc. Jour., vol. 89 , p. 1568, 1906.

as Chamberlin, R. T., Tho gases in rocks: Carnegie Inst. Washington Pub. 106, p. 20, 1908
Composition of the gases extracted from pitchblende and carnotite.

[Volumes per unit volume of rock.]

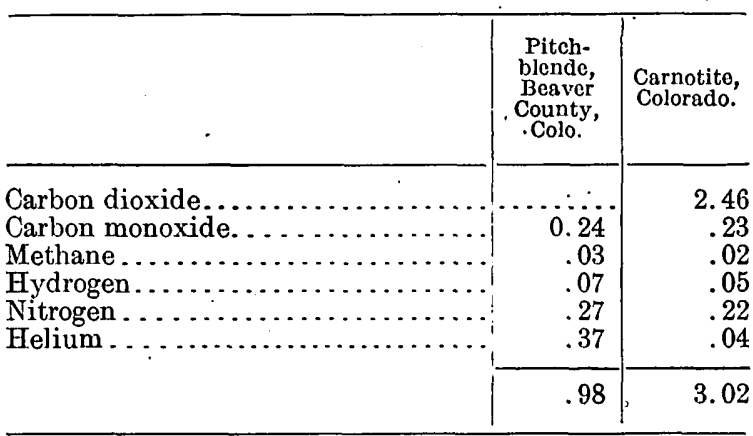

By far the most extensive and systematic investigation has been made by R. J. Strutt, who determined the helium and the radium and thorium content of a great variety of rare and common minerals. In his earlier experiments Strutt extracted the helium by heating a considerable quantity of the powdered mineral to redness and purifying the gas thus obtained first by sparking and finally by absorption in cooled charcoal. The extraction of helium by the use of red heat is by no means complete, the helium extracted being probably only about half that which the mineral contains. The table on page 44 shows the helium content of some of the minerals examined by Strutt ${ }^{66}$ and also the value of uranium oxide as calculated from the radium content.

In discussing his results Strutt pointed out that as helium is generated by the decay of uranium, the ratio of helium to uranium should be of the same order in all minerals, though greater in ancient minerals than in recent ones. In order to test this hypothesis, Strutt next examined groups of similar minerals from different geologic horizons. In this investigation the crude method of extracting the helium by heat was abandoned, and a method of fusion and solution, which permitted complete extraction of helium, was used. Thorium

${ }^{66} \mathrm{Strutt}, \mathrm{R}$.J., Helium and radioactivity in rare and common minerals: Roy. Soc. London Proc., ser. A, vol. 80, p. 572, 1908; The accumulation of helium in geologic time: Idem, vol. 81, p. 272, 1908; vol. 83, p. 96, 1909; vol. 84, p. 194, 1910 
Helium content of certain minerals.

[Helium extracted by heat, except as otherwise noted.]

\begin{tabular}{|c|c|c|c|}
\hline Mineral. & Locality. & $\begin{array}{l}\text { Helium (cubic } \\
\text { willimeters } \\
\text { per gram). }\end{array}$ & $\begin{array}{c}\mathrm{U}_{3} \mathrm{O}_{8} \text { (grams } \\
\text { per } \\
100 \text { grams). }\end{array}$ \\
\hline 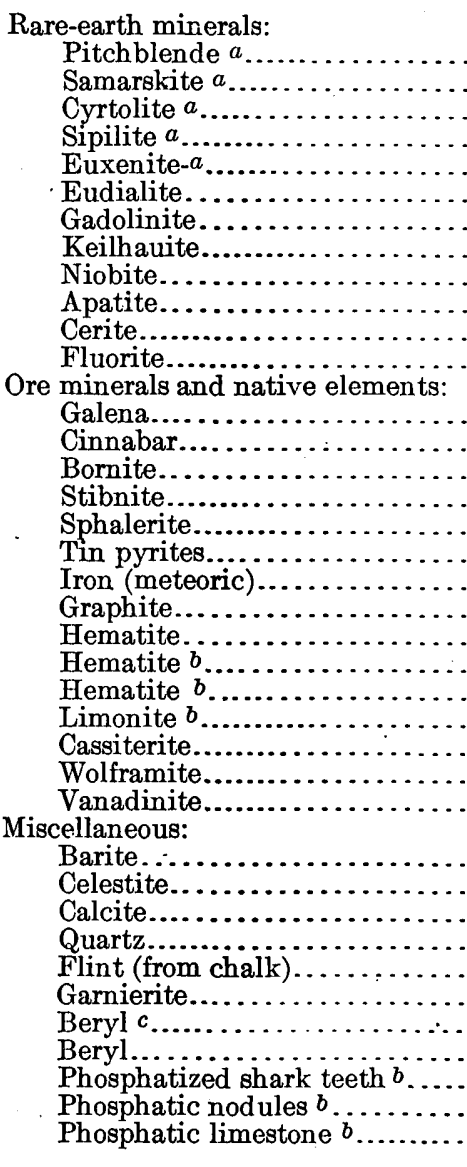 & 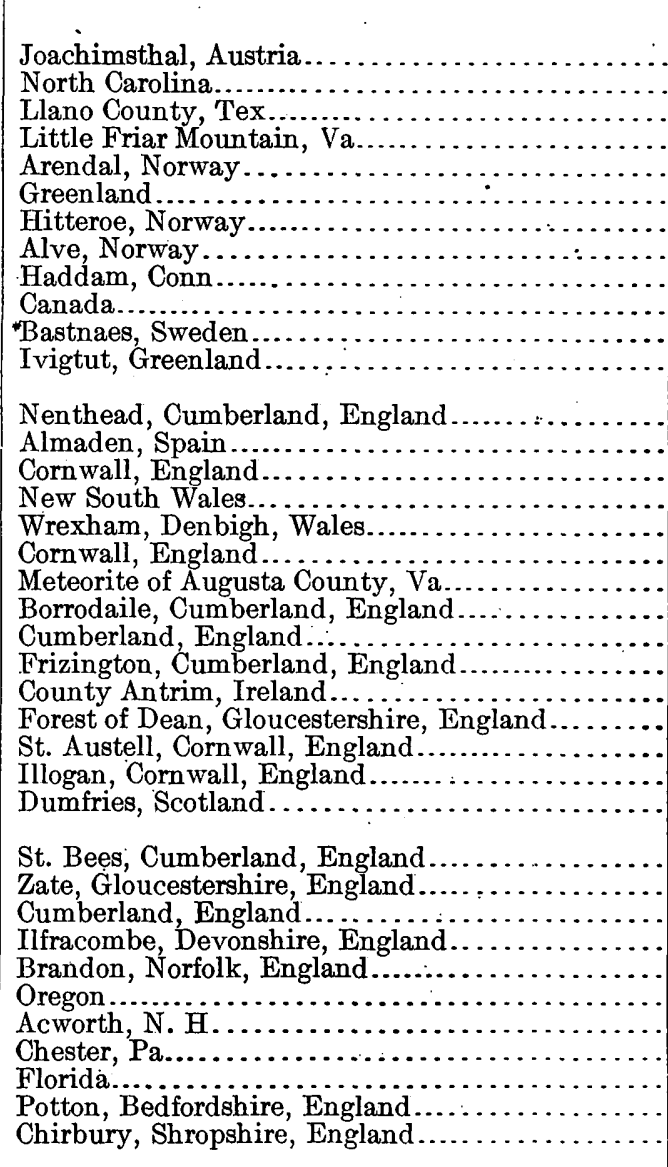 & $\begin{array}{c}107 \\
1,500 \\
1,150 \\
590 \\
730 \\
1.46 \\
10.5 \\
16.3 \\
3.60 \\
1.16 \\
1.26 \\
27.00 \\
. \\
.0007 \\
.0 \\
.12 \\
.007 \\
.0007 \\
.0046 \\
<.0016 \\
.04 \\
.07 \\
.16 \\
.012 \\
.15 \\
.04 \\
1.16 \\
.0 \\
\\
.0008 \\
.0004 \\
<.0006 \\
.0012 \\
.0002 \\
.0027 \\
12.8 \\
6.69 \\
.0017 \\
.021 \\
.056 \\
.05\end{array}$ & $\begin{array}{l}73.5 \\
10.3 \\
3.67 \\
2.86 \\
2.84 \\
3.9 \times 10^{-3} \\
4.2 \times 10^{-2} \\
1.4 \times 10^{-1} \\
3.0 \times 10^{-2} \\
4.5 \times 10^{-3} \\
9.3 \times 10^{-3} \\
4.9 \times 10^{-4} \\
9.0 \times 10^{-6} \\
\\
3.2 \times 10^{-3} \\
1.3 \times 10^{-4} \\
7.0 \times 10^{-5} \\
3.1 \times 10^{-5} \\
7.8 \times 10^{-0} \\
1.1 \times 10^{-3} \\
1.57 \times 10^{-3} \\
1.28 \times 10^{-3} \\
2.64 \times 10^{-4} \\
10.3 \times 10^{-4} \\
3.9 \times 10^{-4} \\
1.05 \times 10^{-2} \\
\end{array}$ \\
\hline
\end{tabular}

a Method of extracting helium not stated.

$c$. Helium extracted by fusion and solution.

was also determined, so as to permit calculation of the ratio between helium and both the elements that generate it. In the table on page 45 the figures under the heading "Total equivalent $\mathrm{U}_{3} \mathrm{O}_{8}$ " are obtained by adding the quantity of $\mathrm{U}_{3} \mathrm{O}_{8}$ and 0.203 times the quantity of $\mathrm{ThO}_{2}$, the assumption being that $1 \mathrm{gram}$ of $\mathrm{ThO}_{2}$ is equivalent to 0.203 gram of $\mathrm{U}_{3} \mathrm{O}_{8}$, so far as helium generation is concerned, and the helium ratio is obtained by dividing the helium in cubic centimeters per gram by the total equivalent uranium oxide.

Reserving for discussion below the significance of the helium ratio as an indication of the age of minerals, we may note here that a great variety of minerals contain helium and that in general its presence appears to be explained by the presence of uranium or thorium. The proportion of helium is therefore not characteristic of any mineral species but is generally very different in different specimens. ${ }^{67}$ In pitchblende, however, the quantity of helium is generally very low in proportion to that of uranium, the ratio in the Joachimsthal variety being only 0.146 , and on the other hand there are certain minerals in which the quantity of helium is far greater than can be explained by the uranium or thorium present. The beryls, for example, are generally very rich in helium

or Piutti, A., Sur les minéraux nonradioactifs contenant de l'hélium: Le Radium, vol. 7, pp. 146, 178, 1910. Debierne, A., Expériences diverses sur la production de l'helium: Annales phys., vol. 2, p. 478, 1914. 
and very poor in the radio-elements, the ratio. In this connection it may be noted that in the Acworth beryl being 9,140. Piutti Valentiner ${ }^{71}$ examined blue rock salt and examined 26 beryls and other glucinum-bearing reported 0.13 cubic centimeter of helium per 100 minerals that contained no uranium or thorium grams, as compared with Strutt's figure of and found helium in varying quantities in all 0.0233 cubic centimeter per 100 grams in the of them. ${ }^{88}$

ordinary variety.

Helium, uranium, and thorium content of zircon, sphene, and thorianite. a

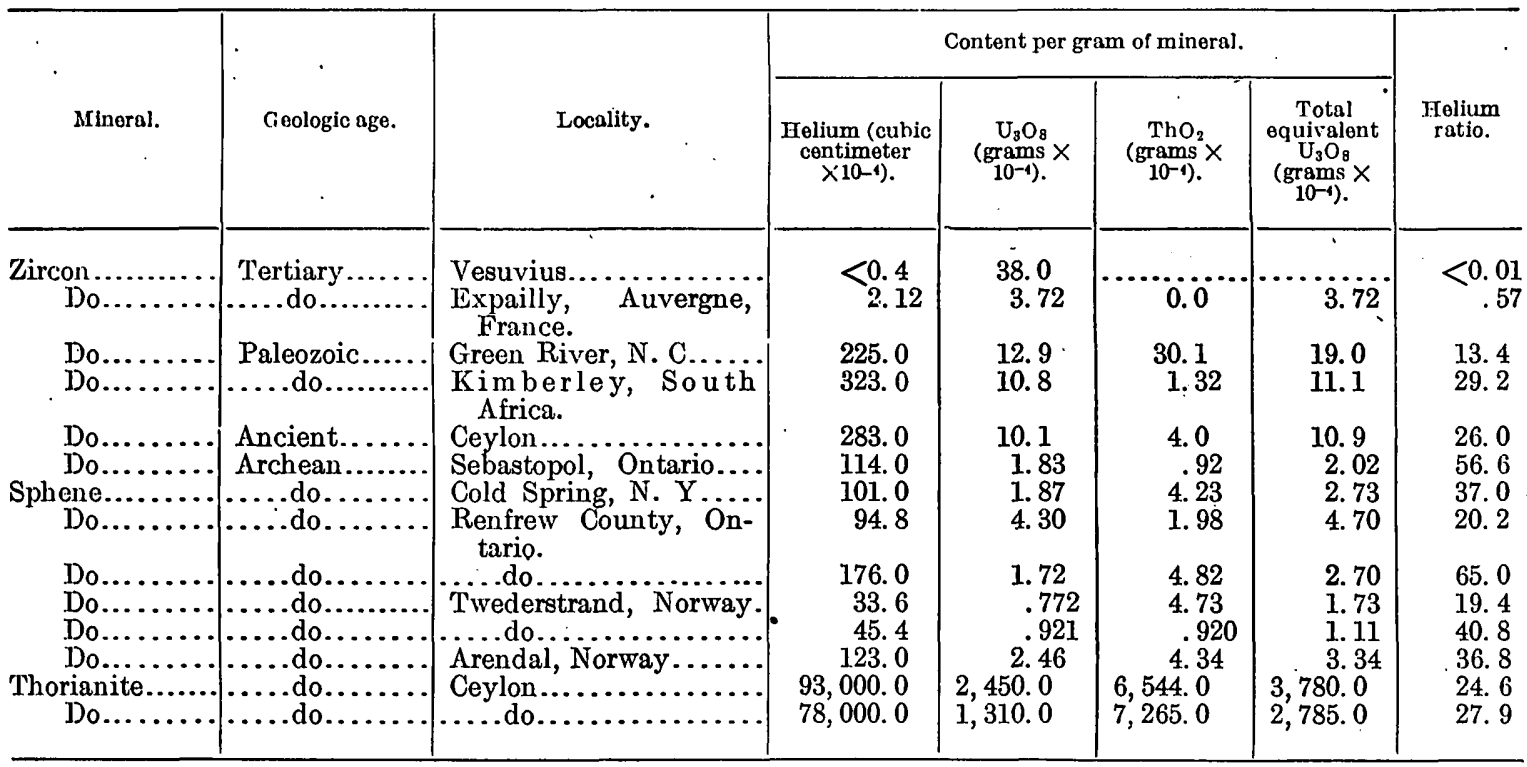

a Strutt, R.J., The accumulation of helium in geological time: Roy. Soc. London Proc., ser. A, vol. 83, p. 298, 1909; vol. 84, p. $194,1910$.

Another group of helium-bearing minerals that are poor in radioactive substances are the potash salts. Potassium is indeed radioactive itself, but so far as known it emits no alpha rays and therefore does not generate helium. ${ }^{00}$ Strutt ${ }^{70}$ examined a number of the Stassfurt potash minerals and found abnormally large quantities of helium in some and very small quantities in others. His quantitative results are given in the following table:

Helium content of some Stassfurt salts.

\begin{tabular}{|c|c|c|c|}
\hline$\cdot$ & $\begin{array}{l}\text { Helium } \\
\text { (cubic mil-- } \\
\text { limeters } \\
\text { per } 100 \\
\text { grams). }\end{array}$ & $\begin{array}{c}\cdot \\
\mathrm{U}_{3} \mathrm{O}_{8} \text { (grams } \\
\text { per } 100 \text { grams). }\end{array}$ & $\begin{array}{c}\text { Helium } \\
\text { (cubic cen } \\
\text { timeters } \\
\text { per rgam } \\
\left.\mathrm{U}_{3} \mathrm{O}_{8}\right) .\end{array}$ \\
\hline $\begin{array}{l}\text { Halite }(\mathrm{NaCl}) \ldots \ldots \ldots \ldots \\
\text { Sylvite }(\mathrm{KCl}) \ldots \ldots \ldots \ldots \\
\text { Carnallite }\left(\mathrm{KMgCl}_{3} .6 \mathrm{H}_{2} \mathrm{O}\right) \\
\text { Kieserite }\left(\mathrm{MgSO}_{4} \cdot \mathrm{H}_{2} \mathrm{O}\right) \ldots\end{array}$ & $\begin{array}{l}0.0233 \\
.55 \\
.151 \\
.0179\end{array}$ & $\begin{array}{l}7.1 \times 10^{-6} \\
2.15 \times 10^{-6} \\
3.23 \times 10^{-6} \\
6.47 \times 10^{-5}\end{array}$ & $\begin{aligned} 3 . & 3 \\
256 . & 0 \\
47.0 & \\
. & 277\end{aligned}$ \\
\hline
\end{tabular}

os Piutti, A., L'olio nei mincrali di glucinio: R. Acead. Lincei Atti, .vol. 22, pt. 1, pp. 140, 671, 1913.

" Campbell, Norman, The beta rays from potassíum: Cambridgo Philos. Soc. Proc., vol. 14, pt. 2, p. 211, 1907.

${ }^{70}$ Strutt, R. J., On helium in saline minerals, and its probable connection with potassium: Roy. Soc. London Proc., ser. A, vol. 81, p. 278, 1908.
HELIUM CONTENT OF ROCKS.

Comparatively few determinations of the helium content of rocks have been made, and most of the minerals examined for helium are not important as rock-forming varieties. Ramsay and Travers, ${ }^{72}$ in their early research on the distribution of helium, examined gneiss, lava from Iceland, serpentine, and blue clay from Kimberley, South Africa, with negative results. Gautier, in his classic investigation of the composition of gases in rocks, ${ }^{73}$ reports that helium was never found except in spectroscopic traces, though the gases of many rocks are rich in nitrogen and in argon. Strutt, however, examined four igneous rocks and found the proportions of helium, argon, and uranium oxide shown in the table on page $46 .^{74}$

n Valentiner, Siegfiried, Heliumgehalt im blauen Steinsalz: Kali, vol. 6, pp. 1-3, 1912.

72 Ramsay, William, and Travers, M. W., The gaseous constituents of certain mineral substances and waters: Proc. Roy. Soc. London, vols 60, p. $442,1897$.

${ }_{73}$ Gautier, A., Produits gazeux dégagés par la chalour de quelqueroches ignées: Compt. Rend., vol. 132, p. 58, 1901; Sur l'existence d'azo tures, argonures, arseniures et iodures dans les roches cristalliniennes Idem, p. 932 .

Idem, p. 932 . als: Roy. Soc. London Proc., ser. A, vol. 80, p. 586, 1908. 
Helium, argon, and uranium oxide in igneous rocks.

\begin{tabular}{|c|c|c|c|c|}
\hline Rock. & Locality. & $\begin{array}{c}\text { Helium } \\
\text { (cubic mil- } \\
\text { limeters } \\
\text { per gram). }\end{array}$ & $\begin{array}{c}\text { Argon } \\
\text { (cubic mil- } \\
\text { limeters } \\
\text { per gram). }\end{array}$ & $\begin{array}{l}\mathrm{U}_{3} \mathrm{O}_{8} \text { (grams per } \\
100 \text { grams). }\end{array}$ \\
\hline 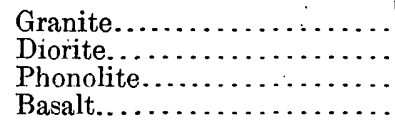 & 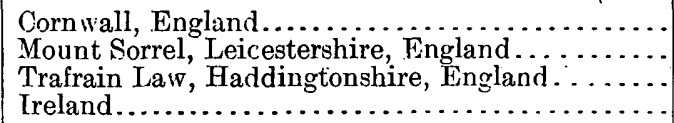 & $\begin{array}{l}0.029 \\
.005 \\
.0086 \\
.0019\end{array}$ & $\begin{array}{l}0.010 \\
.016 \\
.013 \\
.0025\end{array}$ & $\begin{array}{l}8.7 \times 10^{-4} \\
2.0 \times 10^{-4} \\
1.9 \times 10^{-4}\end{array}$ \\
\hline
\end{tabular}

Strutt used red heat in extracting the helium. from these rocks, and it may therefore be presumed that the proportions shown in the table are only about half the true values. Strutt reports that limestone and gypsum generally contain very little if any helium.

TIME CALCULATIONS BASED ON HELIUM CONTENT.

As the radio-elements in minerals are continually breaking down and emitting helium at a constant rate, it is obvious that the ratio of helium to uranium and thorium should be greater in ancient minerals than in recent ones, and all of Strutt's later work on helium in minerals was designed to investigate this relation between helium ratio and age. His work on limestones, phosphatic rocks, and iron ores of diverse ages yielded results of negative value in this connection, for the increase of the helium ratio with age proved to be highly irregular. Practically all the sphenes he examined were of Archean age and showed divergent ratios, but a series of zircons yielded more concordant results, the helium ratio increasing from 0.01 in a Tertiary variety to 56.6 in an Archean variety. (See p. 45.) Strutt then attempted to determine experimentally the rate at which helium is produced and, having obtained a figure in close agreement with that obtained by calculation, ${ }^{75}$ declared the helium ratio to be a reliable index of the antiquity of minerals and therefore a measure of the length of geologic time. (See table, p. 45.) On this basis Strutt concluded that the Archean sphene of Renfrew County, Ontario, is $710,000,000$ years old.

It will be observed that this far-reaching conclusion involves three assumptions- $(a)$ that the rate of decay of the radio-elements is invariable; $(b)$ that all the helium generated in the mineral has been retained by it during

75 Strutt, R. J., Measurements of the rate at which helium is produced in thorianite and pitchblende, with a minimum estimate of their antiquity: Roy. Soc. London Proc., ser. A, vol. 84, p. 379, 1910. geologic time; and (c) that the mineral contained no helium at the outset and has since absorbed none from extraneous sources. A corollary of the general theory which makes it of interest in connection with the origin of helium in natural gas is the tacit assumption that all helium is of radioactive origin.

(a) The rates of decay of the radio-elements have been measured by a number of observers, and although the adopted figures are still subject to modification as more data become available, there seems little likelihood of extensive change. The law of decay is unaffected by such variations in temperature and pressure as can be produced in the laboratory, though its constancy under the temperatures and pressures existing in the earth is debatable. (See p. 12.) Moreover, it is obvious that the law of decay has been measured only for a period of a few years, whereas its application to the age of minerals involves extrapolating it to millions or billions of years.

(b) Strutt ${ }^{76}$ has shown that there is a rapid leakage of helium from minerals and that weathered or water-worn minerals probably contain only a part of the helium that has been generated in them. The mere fact that enormous volumes of helium are found in natural hydrocarbon gas and in other gases of course also indicates that helium is migratory. The escape of helium, then, may result in greatly decreasing the helium ratio and thus the apparent age of a mineral.

(c) As helium is a widely distributed element and is found in volcanic and hot-spring gases, it is not unreasonable to suppose that helium is occluded or dissolved in igneous magmas and that when crystallization begins some of the helium enters into the forming minerals just as nitrogen, argon, hydrogen, and other gases do. ${ }^{77}$ The quantity so occluded

${ }_{76}$ Strutt, R. J., The leakage of helium from radioactive minerals: Roy. Soc. London Proc., ser. A, vol. 82, p. 166, 1909.

77 See the papers by Gautier and Chamberlain cited on pp. $43,45,51$. 
might be very small in proportion to that later generated in the mineral by radioactivity, but it also appears possible for helium to enter the mineral after its formation and thus still further to increase its apparent age. Jaquerod and Perrot ${ }^{78}$ have shown that quartz absorbs helium at a measurable rate even at so low a temperature as $220^{\circ} \mathrm{C}$., and Piutti ${ }^{79}$ found that certain other fused salts and minerals also absorb it at moderate temperatures. The very common presence of helium in beryls, in quantities far larger than can be accounted for by the radio-elements present, is probably to be explained in this way, and it is very possible that the helium in potassium minerals has also entered from some extraneous source.

If minerals under some conditions give up helium and under others absorb it, the writer believes that little reliance can be placed on the helium ratio as a basis for age calculations. The widely divergent ratios obtained by Strutt for minerals of the same geologic age and even from the same locality certainly indicate that disturbing factors have affected the ratio, and there is every reason to believe that these factors may have been additive, increasing the recognized that the general evidence afforded by the distribution of helium in minerals suggests, with several outstanding exceptions, that the helium is a product of radioactivity.

HELIUM IN MINE GASES. .

Apparently helium has been sought for in only a few mine gases, but it has been identified in the fire damp of several coal mines in northern France and Belgium, and in the gas escaping in a potash mine near Stassfurt, Germany. As the gas escaping in many mines is known to be high in nitrogen, ${ }^{81}$ however, it appears probable that helium is a constituent of many mine gases.

One of the first exhaustive studies of mine gases was made in 1896 by Schloesing, ${ }^{82}$ who discovered the presence of argon in the fire damp of French coal mines. In 1911 Moureu and Lepape ${ }^{83}$ examined gas from the same mines and determined the proportions of helium, xenon, neon, krypton, and argon. The mutual proportions of the rare gases were found to approximate their proportions in the atmosphere (see p. 16), but the helium varied greatly, as shown in the following table:

Composition of coal gases.

\begin{tabular}{|c|c|c|c|c|c|}
\hline & Liévin, France. & Anzin, France. & Lens, France. & Mons, Belgium. & $\begin{array}{c}\text { Frankenholz, } \\
\text { Palatinate. }\end{array}$ \\
\hline 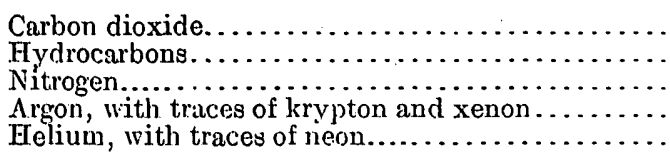 & $\begin{array}{l}0.5 \\
97.03 \\
2.41 \\
.04 \\
.013\end{array}$ & $\begin{array}{r}0.16 \\
97.92 \\
1.85 \\
.021 \\
.044\end{array}$ & $\begin{array}{l}0.0 \\
98.15 \\
\text { 1. } 81 \\
.0367 \\
.0003\end{array}$ & $\begin{array}{l}\text { Trace. } \\
99.60 \\
\quad .32 \\
.003 \\
.050\end{array}$ & $\begin{array}{r}2.80 \\
95.09 \\
2.06 \\
.027 \\
.027\end{array}$ \\
\hline
\end{tabular}

apparent age, as well as subtractive. Attempts have also been made to compute age by the ratio of uranium to lead in minerals, but they need not be discussed here. ${ }^{80}$

Although the attempt to calculate the age of minerals in years from the helium ratio appears to be scarcely warranted, it is nevertheless

78 Jaquerod, A., and Porrot, F. L., Sur l'emploi de l'hélium cómme substance thormométrique ot sur sa diffusion à travers la silice: Compt. Rend., vol. 139, p. 789, 1904.

70 Piutti, Arnaldo, Absorption of helium by rocks and minerals [abstract]: Chem. Soc. Jour., vol. 100, pt. 2, p. 88, 1911.

${ }^{80}$ Holmos, Arthur, The association of lead with uranium in rock minorals and its application to the measurement of geologic time: Roy. Soc London Proc., Ser. A, vol. 85, p. 248, 1911; Radioactivity and the measuromont of geologic time: Geologists Assoc. Proc., vol. 26, pt. 5, p. 289, 1015. Barrell, Joseph, Rhythms and the measurement of geologic time; Geol. Soc. Amorica Bull., vol. 28, p. 745, 1917. For criticisms of this method, soo Becker, G. F., Relations of radioactivity to cosmogony and geology: Geol. Soc. America Bull., vol. 19, p. 134, 1908; Isostasy and radioactivity: Idem, vol. 26, p. 171, 1915. Clarke, F. W., The data of geochemistry, 4th od.: U. S. Geol. Survey Bull. 695, pp. 312-315, 1920.
Although the percentages of helium in these gases are small, the total volumes involved are considerable; according to the authors, the mine at Anzin emits about 4,380 cubic meters a year, and that at Frankenholz 3,650 cubic meters a year. In order to ascertain whether or not the helium is a direct product of radioactivity, Moureu and Lepape then tested the gases for radium emanation but found that they were not measurably radioactive. Ex-

81 For compilations of analyses of mine gases, sec Cady, H. P., and McFarland, D. F., The composition of natural gas, with special study of the constituents of Kansas gases: Kansas. Univ. Geol. Survey, vol. 9, p. 286, 1908. Darton, N. H., Occurrence of explosive gases in coal mines: Bur. Mines Bull. 72, 1915.

${ }^{82}$ Schloesing, Th., fils, Sur la composition du grisou: Compt. Rend. vol. 122, p. 398, 1896; Étude sur l'azote et l'argon du grisou: Idem, vol. 123, p. 233,1896 .

${ }^{83}$ Mourcu, Charles, and Lepape, A., Ies gaz rares des grisous: Compt. Rend., vol. 153, p. 847, 1911. 
amination of the radium and thorium content the gases accumulating in the tunnels or drifts . of the coal itself yielded the following results: ${ }^{84}$ at the mineral springs of Baden. The helium

Relation between helium content of gas and radioactivity of coal.

\begin{tabular}{|c|c|c|c|c|c|}
\hline . & Liévin. & Anzin. & Lens. & Mons. & Frankenholz. \\
\hline $\begin{array}{l}\text { Helium (with traces of neon) in gas..... per cent.. } \\
\text { Radium in coal....... grams } 10^{-12} \text { per gram of coal.. } \\
\text { Thorium in coal..... grans } 10^{-5} \text { per gram of coal. }\end{array}$ & $\begin{array}{l}0.013 \\
<.02\end{array}$ & $\begin{array}{l}0.014 \\
<.01 \\
<.01\end{array}$ & $\begin{array}{l}0.0003 \\
.97 \\
.33\end{array}$ & $\begin{array}{l}0.050 \\
.04 \\
.03\end{array}$ & $\begin{array}{l}0.027 \\
<.01 \\
.02\end{array}$ \\
\hline
\end{tabular}

It will be noted at once that the proportion of helium in the gas bears no relation to the proportions of radium and thorium in the coal. The Lens coal is by far the most radioactive, and the Lens gas is by far the poorest in helium, in fact, the arrangement of the coals in order of radioactivity is almost exactly the reverse of the arrangement of the gases in order of helium content. The authors cited calculate that the helium emitted by the Frankenholz mine in the last 20 years represents all that would be generated by $33,000,000,000$ tons of such coal in a period of $100,000,000$ years. As there is undoubtedly a great deal more helium still occluded in the unmined coal, they: conclude that only a small part of the helium is being generated directly by radioactive processes and that most of it is fossil helium.

In a salt mine at Leopoldshall, near Stassfurt, a flow of combustible gas was encountered which according to Erdmann ${ }^{85}$ proved to have the following composition:

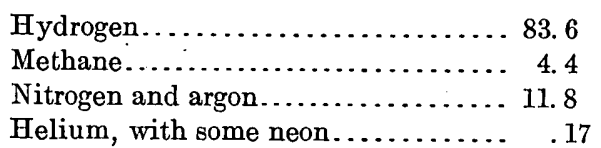

This gas had been flowing for four and a half years, and during that time, it is calculated, 12 cubic meters of helium had escaped. In Erdmann's opinion the helium is generated by the decay of a local deposit of radium in the salt mass and is not an indication of the radioactivity of potassium.

The gas escaping in the Elkton mine, Cripple Creek, Colo., contains 76.8 per cent of nitrogen and 1.5 per cent of argon, but spectroscopic examination of the argon residue apparently failed to disclose the presence of helium. ${ }^{88}$

In this connection may be considered some analyses of gases of a somewhat different type,

\footnotetext{
${ }^{84}$ Moureu, Charles, and Lepape, A., Hélium des grisous et radioactivité des houilles: Compt. Rend., vol. 158, p. 598, 1914.

${ }_{85}$ Erdmann, Ernst, Ưber heliumhaltige Gase der deutschen Kalilager:

Deutsche chem. Gesell. Ber., vol. 43, pt. 1, p. 777, 1910.

${ }^{86}$ Lindgren, Waldemar, and Ransome, F. L., Geology and gold de-

posits of the Cripple Creek district, Colo.: U. S. Geol. Survey Prof. Paper
54, pp. 252-270, 1200.
}

content and radioactivity of these gases, as determined by Sieveking and Lautenschläger, ${ }^{87}$ are as follows:

Helium content and radioactivity of the Stollengase of Baden.

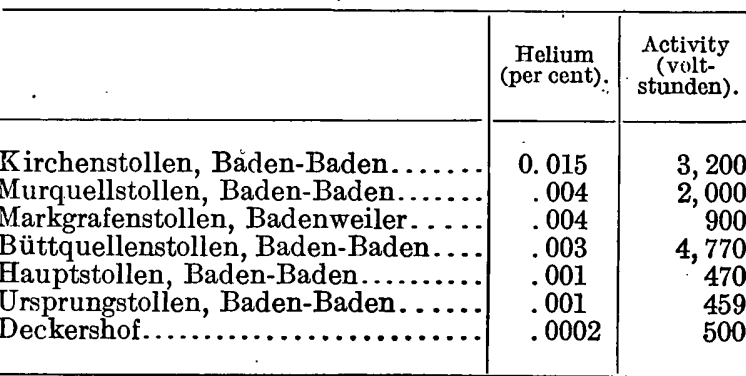

It will be noted that the helium content of these gases appears to bear a vague relation to their radioactivity, though the most active gas stands fourth in order of helium content.

\section{HELIUM IN THE GASES OF MINERAL SPRINGS.}

Within a few months after helium was discovered it was identified by Kayser ${ }^{88}$ in the gas emitted by the springs at Wildbad, in the Black Forest, and in the course of the same year its presence in the springs at Cauterets, in the Pyrenees, was announced by Bouchard and by Kellas and Ramsay. Since that time helium has been detected in the gases of a great many European mineral springs, some of which emit several thousand liters of helium yearly.

By far the most extensive investigations of the occurrence of the rare elements in mineralspring gases are those of Moureu and his collaborators, who found that the proportions of argon, krypton, and xenon in all gases approximate their proportions in the atmosphere, whereas the percentages of helium are very irregular. (See p. 16.) In order to investigate the relation between helium and radioactivity Moureu determined the radium ema-

87 Sieveking, H., and Lautenschläger, L., Über Helium in Thermalquellen und Erdgasen: Physikal. Zeitschr., vol. 13, pt. 2, p. 1043, 1012.

${ }^{88}$ Kayser, H., Note on helium and argon: Chem. News, vol. 72, p. 89, 
nation in a great many gases but found that no brought out in the following table, which presents direct relation exists, except in so far as all the a summary of numerous papers by Moureu: ${ }^{80}$ gases examined contain at least traces of both.
helium and the radio-elemients. This is clearly

Frelium content and radioactivity of the gases of mineral springs.

[After Mouren. Localities in France except as otherwise noted.]

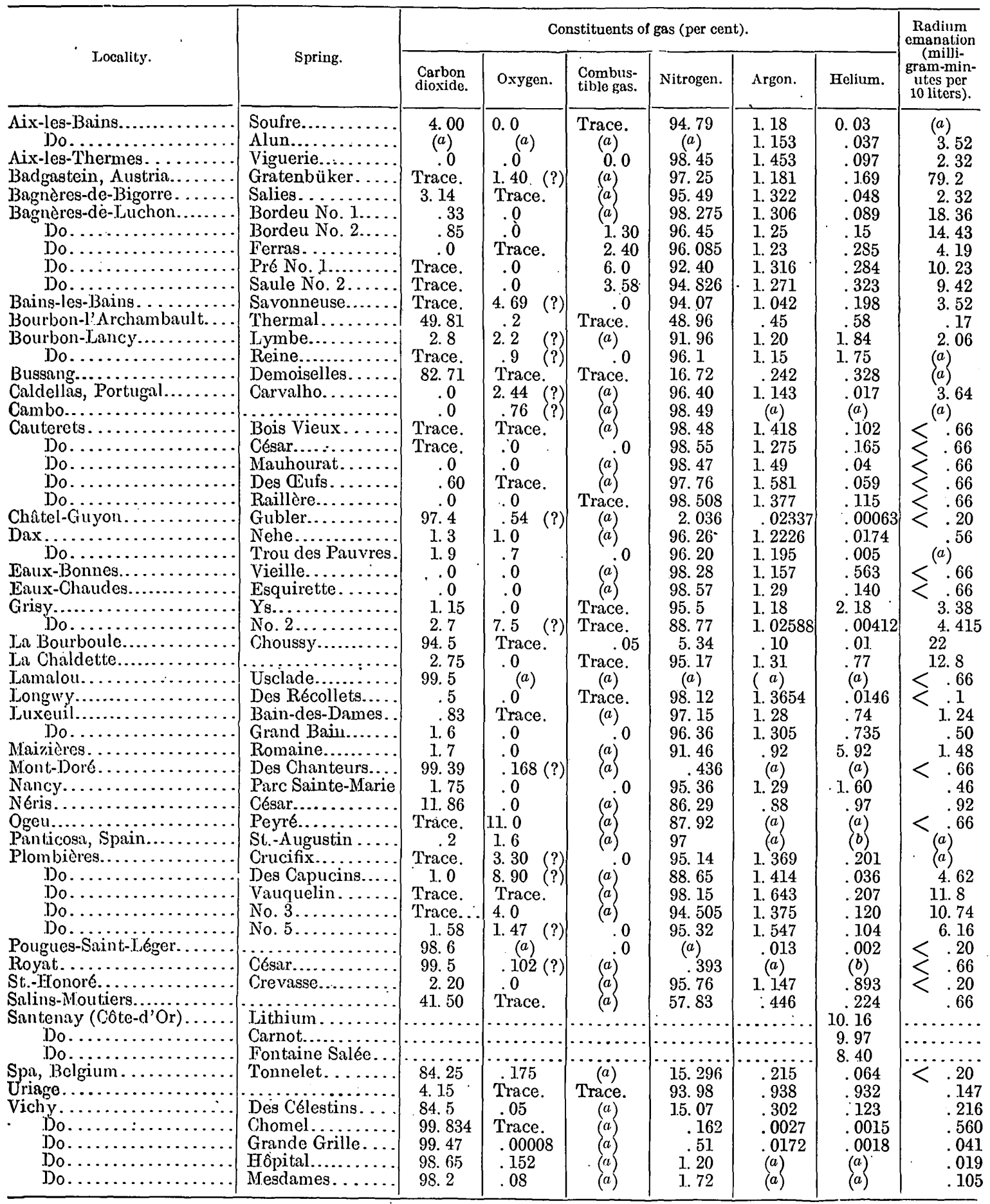

a Not determined.

$101.35^{\circ}-20-4$

$b$ Not sought for. 
Moureu points out the total lack of proportionality between radioactivity and the helium content of these gases and concludes that only a small fraction of the helium is now being generated by the decay of radium and that the greater part is fossil helium. As shown in the following table the volume of helium given off annually by some of the richer springs is considerable; Moureu calculates, for example, that the output of the Carnot Spring, at Santenay, represents, all the helium that would be given off in a year by 91 tons of radium, or by $500,000,000$ tons of pitchblende or thorianite. It is very evident, therefore, that the helium of these springs is not being generated by radioactivity as fast as it is being emitted, and that it represents the leakage from a great store of underground helium, which may have been generated during geologic time by the radio-elements or may represent primordial helium that has had no connection with radioactivity.

Volumes of helium emitted annually by some of the richer French mineral springs. a

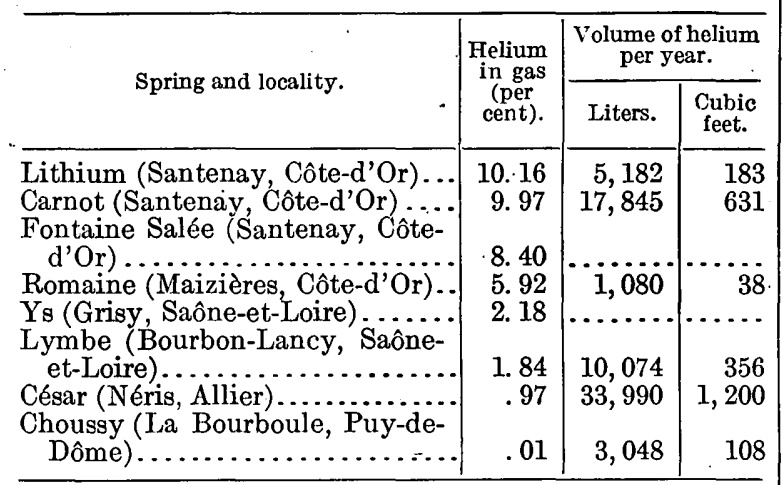

a Moureu, Charles, and Lepape, A., Sur quelques mélanges gazeux naturels particulièrement riches en hélium; Gisements d'hélium: Compt. Rend. vol. 155, p. 197, 1912 .

All these springs, except that at La Bourboule, lie in a comparatively narrow belt extending from Moulins, in Allier, northeastward to Vesoul, in Haute-Saône; and in this belt also thiere are several other springs which furnish gas containing more than 0.5 per cent helium, such as those at Luxeuil, St. Honoré, and Bourbon-l'Archambault. This areal distribution of the helium probably has a significance which special geologic examinations might disclose, but the surface geology of this region, as shown on the geologic map of France, suggests no explanation.
Although a few of the helium-bearing spring gases cited in the foregoing tables consist chiefly of carbon dioxide, a great majority are rich in nitrogen, resembling in this respect the helium-bearing natural gases of the United States. The general occurrence of helium in nitrogen-rich spring gases is shown in the following table, which has been compiled from a number of papers:

Helium and argon in the gases of mineral springs.

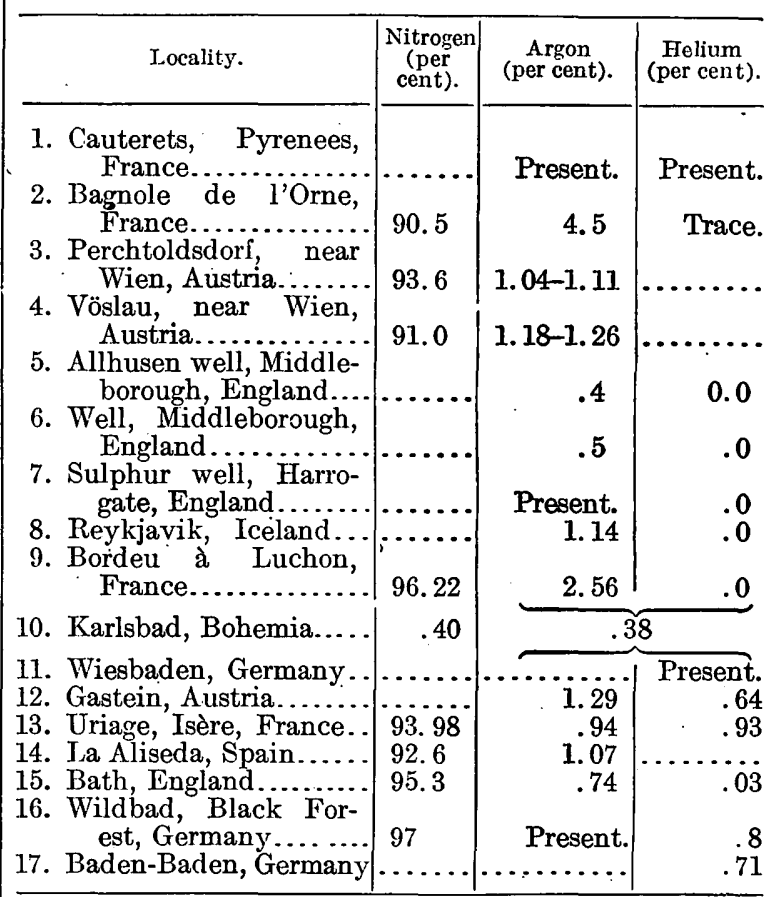

1. Bouchard, Charles, Sur la présence de l'argon et de l'hélium dans certaines eaux minerales: Compt. Rend., vol. 121, p. 392, 1895.

2. Bouchard, Charles, Sur la composition des gaz qui se degagent des 3. Bamberger, Max, Über den Nachweis von Argon in dem einer Quelle in Perchtoldsdorf bei Wien: Monatsh. Chemie, Band 17, p. 604, 1896 .

4. Bamberger, M., and Landsiedl, A., Über den Nachweis von Argon in den Badequellen von Vöslau bei Wien: Idem, vol. 19, p. 114, 1898.

5, 6, 8. Kellas, Alexander, and Ramsay, William, Examination of ases from certain mineral waters: Chem. News, vol. 72, p. 295, 1895. 7. Ramsay, William, and Travers, M. W., The gaseous constituents of certain mineral substances and waters: Roy. Soc. London Proc., vol. 60, p: $442,1897$.

9. Moissan, Henri, Sur la présence de l'argon dans les gaz de la source Bordeu a Luchon et sur la présence du soufre libre dans l'eau sulfureuse
de la grotte et dans les vapeurs de humage: Compt. Rend., vol. 135, p. 1278,1902

p. 1278,1902 . Pesendorfer, F., Zusammensetzung des dem Karlsbad Sprude entströmenden Gases: Chem. Zeitung, vol. 29, p. 359, 1905 .

11. Henrich, Ferd., Untersuchungen iuber die Thermalquellen von wiesbaden und deren Radioaktivität: Physikal. Zeitschr., vol. 8, p. 112 1907.

12. Ewers, P., Über das Vorkommen von Argon und Helium in den Gasteiner Thermalquellen: Physikal. Zeitschr., vol. 7, p. 225, 1906. 13. Massol, M. G., Sur la composition chimique des gaz spontanés de la source thermo-minérale d'U riage (Isère): Compt. Rend., vol. 151, p. 1124,1910 .

14. Diaz de Rada, F., Analyse der aus dem Quellwasser von " $\mathrm{La}$ Aliseda" sich entwickelnden Gase: Chem. Zeitung, vol. 36, p. 688, 1912.

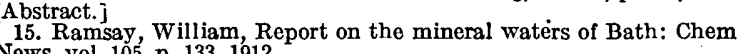
News, vol. 105, p. 133, 1912 .

male 
An examination of sea water and of the water of the Seine for helium was made by Troost and Ouvrard, ${ }^{00}$ who report that it is present only in the faintest traces.

\section{HELIOM IN VOLCANIC AND FUMAROLE GASES.}

Unfortunately the earlier classic researches on the composition of volcanic gases-those of Bunsen, Deville and Leblanc, and Fouqué- gas of the solfatara of Pozzuoli (Campi Flegrei, near Naples) and in several other Vesuvius gases, as well as in the hydrocarbon gases of Salsomaggiore and Bagni della Poretta, in northern Italy. ${ }^{92}$ The following table shows some of the analyses made by these authors, as well as a later analysis of the Larderello gas made by Porlezza and Norzi, ${ }^{03}$ and an analysis of Vesurius gas by Gautier:04

Analyses of gases of Italian fumaroles.

[Per cent.]

\begin{tabular}{|c|c|c|c|c|c|}
\hline & 1 & 2 & 3 & 4 & 5 \\
\hline 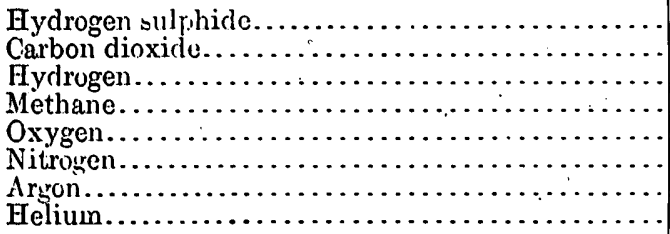 & $\begin{array}{r}2.070 \\
92.800 \\
2.600 \\
1.400 \\
.050 \\
1.048 \\
.021 \\
.010\end{array}$ & $\begin{array}{r}2.000 \\
92.000 \\
2.400 \\
1.900 \\
.200 \\
1.455 \\
.029 \\
.014\end{array}$ & $\begin{array}{r}2.0000 \\
92.2000 \\
2.4500 \\
1.7800 \\
.1300 \\
1.3500 \\
.0245 \\
.0155 .\end{array}$ & $\begin{array}{r}1.13 \\
10.73 \\
12.00 \\
.40 \\
74.23 \\
1.51\end{array}$ & $\begin{array}{r}96.52 \\
.015 \\
.12 \\
.46 \\
2.87 \\
.028\end{array}$ \\
\hline & 99.999 & 99.998 & 100.0000 & 100.00 & 100. 013 \\
\hline
\end{tabular}

1-2. Gas from different parts of the boric acid soffione of Larderello. Analysis by Nasini, Anderlini, and Salvadori.

3. Same. Later analysis by Porlezza and Norzi.

4. Gas from boiling spring at Monte Irone, A bano. Analysis by Nasini, Anderlini, and Salvadori.

5. Cas from old fumarole at Agnano, near Naples, representing Vesuvius gas. Analysis by A. Gautier; helium determined by Charles Moureu.

were made before helium was discovered, and as most of the recent investigations deal only with the more abundant constituents of volcanic emanations, the available data on the distribution of helium in such gases are meager.
The gases emitted by the boiling springs of Iceland, which are indirect manifestations of volcanic activity, have been investigated by Thorkelsson, ${ }^{95}$ from whose valuable paper the following analyses are cited:

Analyses of gas emitted by the hot springs of Iceland.

[Per cent.]

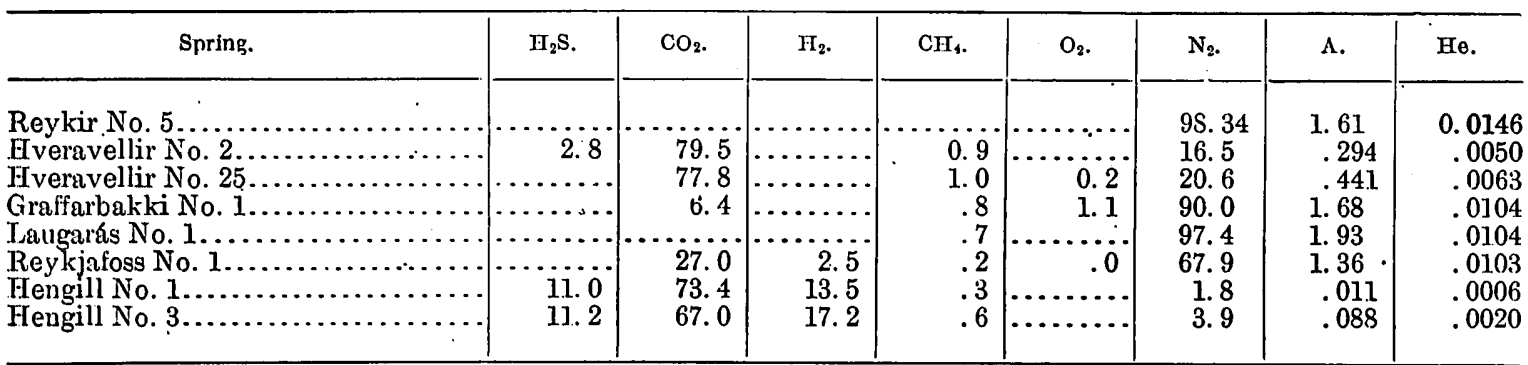

The presence of helium in Italian fumarole gases was established in 1898 by Nasini, Anderlini, and Salvadori, who found 0.014 per cent of helium in the gas emitted by the boric acid soffione of Larderello (Tuscany), and a smaller proportion in the gas of Monte Irone, Abano. ${ }^{91}$ The same authors later detected helium in the

00 Troost, L., and Ouvrard, L., Sur l'origine de l'argon et de l'helium dans les gaz dégagés par certaines eaux sulfureuses: Compt. Rend., vol. 121, p. $798,1895$.

ol Nasini, R., Anderlini, F., and Salvadori, R., Ricerche sulle emanazioni terrestro italiane: Gazz. chim. ital., vol. 28, pp. 81-153, 1898.
Moissan $^{96}$ examined several samples of gas from the fumaroles of Mont Pelee, Martinique, but reported no helium in one sample and

92 Idem, vol. 36, pt. 1, p. 429, 1906.

93 Porlezza, C., and Norzi, G., Nuovi studi sui gas dei soffione boraciferi di Larderello: R. Accad. Lincei Atti, 5th ser., vol. 20, pt. 2, p. 338, 1911.

94 Gautier, Armand, Observations sur la nature et l'origine des gaz qui forment les fumerolles volcaniques ou qui sortent des cratères des anciens volcans: Compt. Rend., vol. 149, p. 84, 1909. •

is Thorkelsson, Thorkell, The hot springs of Iceland: Acad. roy. sci. et let. Danemark Mém., 7th ser., vol. 8, pp. 181-264, 1910.

${ }_{96}$ Moissan, Henri, Sur la présence de l'argon, de l'oxyde de carbone et des carbures d'hydrogène dans les gaz des fumerolles du Mont Pele a la Martinique: Compt. Rend., vol. 135, p. 1085, 1902. 
apparently did not look for it in the others. been calculated roughly by $\mathrm{Jeans}^{3}$ and are Grossman, ${ }^{97}$ however, found traces of helium given in the following table:

Proportions of the atmospheric gases at various levels in the upper atmosphere.

[The base of the upper atmosphere is taken at 10.5 kilometers above the earth's surface.]

\begin{tabular}{|c|c|c|c|c|c|c|}
\hline \multirow{2}{*}{ Gas. } & \multirow{2}{*}{$\begin{array}{l}\text { Molecular } \\
\text { weight. }\end{array}$} & \multicolumn{5}{|c|}{ Number of molecules per cubic centimeter at height $z$ (in kilometers). } \\
\hline & & $z=0$ & $z=20$ & $z=80$ & $z=160$ & $z=800$ \\
\hline 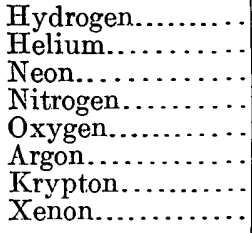 & $\begin{array}{r}2 \\
4 \\
20 \\
28 \\
32 \\
40 \\
83 \\
130\end{array}$ & $\begin{array}{r}10 \times 10^{13} \\
4 \times 10^{13} \\
12.5 \times 10^{13} \\
780,600 \times 10^{13} \\
210,000 \times 10^{13} \\
9,400 \times 10^{13} \\
0.5 \times 10^{13} \\
0.06 \times 10^{13}\end{array}$ & $\begin{array}{r}8 \times 10^{13} \\
2.6 \times 10^{13} \\
1.4 \times 10^{13} \\
42,900 \times 10^{13} \\
7,000 \times 10^{13} \\
139 \times 10^{13} \\
10^{9} \\
10^{5}\end{array}$ & $\begin{array}{r}430 \times 10^{11} \\
73 \times 10^{11} \\
0.3 \times 10^{11} \\
520 \times 10^{11} \\
25 \times 10^{11} \\
0.04 \times 10^{11} \\
0 \\
0\end{array}$ & $\begin{array}{r}182 \times 10^{11} \\
13 \times 10^{11} \\
0.5 \times 10^{7} \\
35 \times 10^{7} \\
0.3 \times 10^{7} \\
10^{2} \\
0 \\
0\end{array}$ & $\begin{array}{c}3 \times 10^{10} \\
10^{6} \\
0 \\
0 \\
0 \\
0 \\
0 \\
0\end{array}$ \\
\hline & & $1 \times 10^{19}$ & $5 \times 10^{17}$ & $1 \times 10^{14}$ & $2 \times 10^{13}$ & $3 \times 10^{10}$ \\
\hline
\end{tabular}

in the gas contained in lava from Mont Pelée, but none in several lavas from Vesurius and other localities. Day and Shepherd ${ }^{98}$ state that the gases of Kilauea examined by them contain no helium, argon, or other rare gases.

\section{HELIUM IN THE ATMOSPHERE.}

According to the latest determination by Sir William Ramsay ${ }^{99}$ the atmosphere near the earth's surface contains 1 part of helium in 245,300 parts by volume, or about 0.0004 per cent. This is the figure generally accepted, though according to Claude ${ }^{1}$ the percentage is 0.0005 . Joly ${ }^{2}$ has calculated that the atmosphere up to a height of 8 kilometers contains, if homogeneous, $16 \times 10^{14}$ cubic meters of helium.

Although there are a few experimental data on the composition of the air several miles above the earth, it is generally believed that the atmosphere consists of two layers-an inner adiabatic layer 8 or 10 kilometers high, which is practiçally homogeneous in composition, and an outer and much thicker isothermal layer, or layer in which the temperature is uniform and constant and in which the distribution of the gases is controlled by gravity. The theoretical proportions of the several gases at various levels in the upper atmosphere have

${ }_{97}$ Grossman, M., Analyse quantitative des gaz occlus dans les Iaves des dernières éruptions de la Montagne Pelée et du Vésuve: Compt. Rend., vol. 148, p. 991, 1909.

98 Day, A. L., and Shepherd, E. S., Water and volcanic activity: Geol. Soc. America Bull., vol. 24, p. 573, 1913.

${ }_{99}$ Ramsay, William, The gases of the atmosphere, 4 th ed., p. 257, London, 1915.

1 Claude, Georges, Sur la composition de l'air atmosphérique: Compt. Rend., vol. 148, p. 1454, 1909.

2 Joly, J., Radioactivity and geology, p. 210, London, 1909.
At a height of 80 kilometers (50 miles) some of the heavier gases disappear entirely, and helium, instead of being the sixth constituent in order of abundance, is outranked only by hydrogen and nitrogen. At a height of 160 kilometers (100 miles) the atmosphere consists chiefly of hydrogen and helium, the other constituents being present only in small proportions.

C. E. Van Orstrand has constructed a curve from the foregoing figures and has computed the relative volumes of helium in the concentric zones of the atmosphere, as follows:

Proportions of helium in the atmosphere at different levels above the earth's surface.

[Number of molecules per cubic centimeter at earth's surface,

\begin{tabular}{|r|r||r|r|}
\hline $\begin{array}{c}\text { Height (kilo- } \\
\text { meters). }\end{array}$ & $\begin{array}{c}\text { Helium (mole- } \\
\text { cules } \times 10^{16} \text { per } \\
\text { cubic centi- } \\
\text { meter). }\end{array}$ & $\begin{array}{r}\text { Height (kilo- } \\
\text { meters). }\end{array}$ & $\begin{array}{c}\text { Helium (mole- } \\
\text { cules } \times 10^{16} \text { per } \\
\text { cubic centi- } \\
\text { meter). }\end{array}$ \\
\hline $0-2$ & 2,000 & $16-18$ & 620 \\
$2-4$ & 1,600 & $18-30$ & 3,360 \\
$4-6$ & 1,280 & $30-90$ & 9,990 \\
$6-8$ & $1,040$. & $90-170$ & 3,440 \\
$8-10$ & 870 & $170-870$ & 4,550 \\
$10-12$ & 760 & & 30,870 \\
$12-14$ & 700 & & \\
$14-16$ & 660 & & \\
\hline
\end{tabular}

From this figure Mr. Van Orstrand calculates that the total mass of helium in the atmosphere up to 870 kilometers is $11,456 \times 10^{6}$ tons, which is equivalent to a total volume, at standard temperature and pressure, of about $58,186 \times 10^{9}$ cubic meters.

3 Jeans, J. H., The dynamical theory of gases, chap. 15, Cambridge, 1916. Earlier calculations have been given by James Dewar. (Problems of the atmosphere: Roy. Inst. Great Britain Proc., vol. 17, 19021904, p. 223) and by W. J. Humphreys (Distribution of gases in the atmosphere: Mount Weather Obs. Bull., vol. 2, p. 66, 1909). 
It has been argued by Stoney ${ }^{4}$ that hydrogen. because of its lightness, ascends to the uppermost levels of the atmosphere, and thence in part escapes into space; and it has been suggested by both Ramsay ${ }^{5}$ and Moureu ${ }^{8}$ that the same theory may apply to helium as well. According to Jeans, however, the loss of hydrogen from the earth's atmosphere is at present so slow as to be negligible, and there can therefore be practically no loss of helium. A similar conclusion is reached by Bryan.

\section{COSMIC HELIUM.}

The discovery of helium in the solar chromosphere in 1868 was followed by its identification in the spectra of a great many stars, and it is now recognized that helium is one of the most prominent of cosmic elements. Helium is abundant in the nebulae and is so prominent in the hotter stars of the Orion type that these are often designated the helium stars.

In contrast to helium, which is so prominent in the stars and nebulae, the radio-elements, so closely associated with helium on the earth, are conspicuous by their absence. Dyson has doubtfully reported the presence of radium in the solar chromosphere, and Giebeler believes that he has detected radium and its emanation in the spectrum of the new star Nova Geminorum 2, but despite the fact that radium is easily recognized spectroscopically, other observers have failed to confirm these results and report that radium is absent. ${ }^{8}$ Similarly, uranium and thorium, so far as the writer can learn, have not been detected in any of the celestinl bodies, though lead has been identified in the sun.

The prominence of helium and the absence of uranium and thorium in celestial bodies are explained by Becker's view ${ }^{9}$ that uranium is to be regarded as the unstable compound $\mathrm{PbHe}_{8}$ and thorium as the compound $\mathrm{PbHe}_{6}$, which differ from other compounds chiefly in that their disintegration is spontaneous and proceeds at a fixed rate. As these compounds are very strongly endothermic, disintegrating with the

\footnotetext{
4 Stonoy, Johnstone, Chem. News, vol. 71, p. 67, 1895.

- Ramsay, William, op. cit., p. 265.

- Moureu, Charles, Les gez thermaux: Rev. sci., 1914, p. 65.

7 Bryan, G. H., The kinetic theory of planetary atmospheres: Roy.

Soc. London Philos. Trans., vol. 196, p. 1, 1900.

8 Clarke, F. W., The data of geochemistry, 4 th ed.: U. S. Geol. Survey Bull. 605, p. 312, 1920.

$\because$ Bocker, G. F., Relations of radioactivity to cosmogony and geology: Geol. Soc. America Bull., vol. 19, p. 113, 1908.
}

evolution of heat, their formation must have been attended by the absorption of heat and therefore could have taken place only under conditions. of great temperature and pressure. Similar arguments have been developed by Arrhenius and others. ${ }^{10}$ If this view is accepted, the presence of helium and lead in the sun and the absence of their compounds, uranium and thorium, are explained. Furthermore, it follows that if helium and lead combine only under certain conditions there is in all probability a great deal of helium in the earth which has never entered into this combination and has had no connection with radioactivity and which may thus be regarded as true primordial helium.

INFERRED HELIUM.

THE MEASUREMENT OF RADIOACTIVITY.

In addition to the direct data on the distribution of helium reviewed in the foregoing pages, it is evident that, as helium is formed in the decay of the radio-elements, each occurrence of radioactive material connotes the presence of helium. Early recognition of the extraordinary qualities of radium and of its geochemical significance and therapeutic value led to the making of extensive surveys of the distribution of radioactive materials in the earth's crust, and the data so gathered thus have an indirect bearing on the distribution of helium.

Almost inconceivably minute quantities of radium and its products may be accurately measured by taking advantage of the fact that the rays emitted by these substances have the property of ionizing the surrounding gases and so making them carriers of electricity. The extent of this ionization is measured by means of the electroscope, which is designed to permit accurate observation of the rate of loss of potential of a charged insulated strip of gold leaf exposed to a definite volume of air containing the emanation. ' As each alpha ray emitted gives rise to many thousand ions per second, it is evident that measurements made in this way are incomparably more refined than those obtainable by the most delicate chemical balance or even by the spectroscope. Exceedingly small quantities of helium may be recognized in a spectroscope, but far smaller quantities of the elements that give rise to helium may be measured electrically.

${ }^{10}$ See Becker, G. F., Isostasy and radioactivity: Geol. Soc. America Bull., vol. 26, p. 194, 1915. 
In practice sufficient time must of course be allowed to permit the attainment of equilibrium. If a rock is to be tested, it is first brought into solution and allowed to stand until the maximum quantity of emanation has accumulated-that is, until the rate of decay is equal to the rate of production. The gases are then removed by boiling and introduoed into the electroscope, and the measurement of their ionizing power is easily recalculated into terms of radium itself.

\section{DISTRIBUTION OF THE RADIO-ELEMENTS.}

A great many determinations of radium in minerals, soils, rocks, and spring waters and in the ocean and atmosphere have been made, but as their bearing on the distribution of helium is indirect only a few representative measurements will be given here.

Measurements of the radioactivity of a number of minerals, made in connection with determinations of their helium content, have been given on pages 44-45. It will be noted that many of the rare-earth minerals are rich in radium, as compared with ordinary rocks (discussed below), and that practically all the minerals tested contain some radium, though the silicates and the common metallic ore minerals are generally poor.

The wide distribution of the radio-elements in terrestrial materials was discovered in 1901 by Elster and Geitel, who observed that the air in cellars and caves is markedly radioactive and who thereupon tested a number of samples of soil and clay. ${ }^{11}$ They found that most of the samples they examined were distinctly radioactive, and later investigations have confirmed their results. Moore ${ }^{12}$ for example, found the

11 Elster, J., and Geitel, H., Sur la radioactivité de l'atmosphère et du sol: Arch. sci. phys. nat., 4th ser., vol. 17, p. 13, 1904. Determinations of the radioactivity of many minerals, rocks, spring waters, etc., were made prior to 1905 , but the results were commonly expressed in arbitrary units and have little value for comparison. A good review of the work to 1905 , with bibliography, is given by Georg v. d. Borne (Die radioaktiven Mineralien, Gesteine und Quellen: Jahrb. Radioaktivität u. Electronik, Band 2, Heft 1, p. 77, 1905).

12 Moore, R. B., The radioactivity of some type soils of the United States: Jour. Ind. and Eng. Chemistry, vol. 6, p. 370, 1914 average emanation from 14 type soils in the United States to be equivalent to $1.97 \times 10^{-12}$ grams of radium per gram of soil, and that of the subsoils to be equivalent to $1.52 \times 10^{-12}$ grams. ${ }^{13}$ The average thorium emanation of five soils was found to represent $4 \times 10^{-5}$ grams of thorium per gram of soil. Sanderson ${ }^{14}$ examined 13 Minnesota soils and found $1.3 \times$ $10^{-13}$ to $8 \times 10^{-13}$ grams of radium and $2.5 \times$ $10^{-6}$ to $7.1 \times 10^{-6}$ grams of thorium per cubic centimeter of soil.

The first systematic survey of the distribution of radium in rocks was made in 1906 by R. J. Strutt. His results (as corrected by Eve and McIntosh for the use of an erroneous constant) showed the average radium content of 28 igneous rocks from different parts of the world to be $1.7 \times 10^{-12}$ per gram of rock and that of 17 sedimentary rocks to be $1.1 \times 10^{-12}$ gram. Joly, who shortly afterward began a much more extensive survey, obtained results several times as large as Strutt's, the disparity being apparently due to the use of different methods of bringing the specimens into solution. As other investigators have obtained results approximating Strutt's, and as Joly's recent determinations are considerably lower than his earlier ones, it seems probable that most of the earlier results should be rejected.

The accompanying table shows the average radium content of groups of comparable rocks from all over the world, as determined by several investigators. Most of Joly's earlier determinations have been omitted. Although future work will undoubtedly modify the mean values somewhat, a sufficient number of determinations have now been made to permit a fair estimate of the radium content of the earth's surface rocks.

${ }^{13} 1.52 \times 10^{-12}$ grams per gram equals one hundred and fifty-two trillionths of 1 per cent. The radium content of ordinary natural substances is of this order of magnitude.

${ }^{14}$ Sanderson, J. C., Radioactive content of certain Minnesota soils: Am. Jour. Sci., 4th ser., vol. 39, p. 391, 1915. 
Radium content of rocks.

\begin{tabular}{|c|c|c|c|c|c|}
\hline Rock. & Locality. & $\begin{array}{c}\text { Number } \\
\text { of speci- } \\
\text { mens. }\end{array}$ & $\begin{array}{l}\text { Radium } \\
\text { (grams } \times \\
\text { 10-12 per } \\
\text { gram of } \\
\text { rock). }\end{array}$ & $\begin{array}{c}\text { Equiva- } \\
\text { lent value } \\
\text { of uranium } \\
\text { (grams } \times \\
\left.10^{-5}\right)\end{array}$ & Observer. \\
\hline Igneous rocks: & & & & & \multirow{18}{*}{$\begin{array}{l}\text { Strutt. } a \\
\text { Farr and Florance. } b \\
\text { Smeeth and Watson. } c \\
\text { Schlundt and Moore. } d \\
\text { Do. } d \\
\text { Eve and McIntosh.e } \\
\text { Joly. } f \\
\text { Büchner. } g \\
\text {. Do. } h \\
\text { Strutt. } a \\
\text { Do. } a \\
\text { Joly. } f \\
\text { Smeeth and Watson. } c \\
\text { Strutt. } . \\
\text { Joly. } j \\
\quad \text { Do. } j \\
\text { Do. } j\end{array}$} \\
\hline Granites and syenites. & Various.............. & 10 & 3. 33 & & \\
\hline Granites and porphyries.... & $\begin{array}{l}\text { Sub-Antarctic islands. } \\
\text { Mysore, India......... }\end{array}$ & $\begin{array}{r}7 \\
16\end{array}$ & 2.1 & & \\
\hline Rhyolites................. & Yellowstone Park, U. S. A.... & & $\begin{array}{l}1.0 \\
2.3\end{array}$ & & \\
\hline Obsidian ... & $\ldots \ldots$ do $\ldots \ldots \ldots \ldots \ldots \ldots \ldots$ & $\dot{2}$ & 1.9 & & \\
\hline Nephelite rocks........ & Montreal, Canada & 4 & 2. 16 & & \\
\hline Recent volcanic rocks. & Various.......... & 12 & 7.1 & ….... & \\
\hline Various types........... & Sumatra.. & 10 & 1.6 & & \\
\hline Various types............. & Borneo... & 17 & 1. 7 & & \\
\hline Diorites and similar rocks.. & Various.. & 7 & 1. 16 & . & \\
\hline Basic rocks................ & $\ldots \ldots$ do......... & 11 & .53 & & \\
\hline Basalts . . . . . . . . . . & The Deccan, India. & 6 & 4.3 & & \\
\hline Basic rocks (Archean). & Mysore, India........ & 21. & .24 & & \\
\hline Basalts $\ldots \ldots \ldots \ldots \ldots$ & England........... & 4 & .37 & & \\
\hline $\begin{array}{l}\text { Acidic rocks (composite } \\
\text { sample). }\end{array}$ & Various............. & $86^{\circ}$ & 3.01 & & \\
\hline $\begin{array}{l}\text { Intermediate rocks (com- } \\
\text { posite sample). }\end{array}$ & .....do. & 48 & 2.57 & & \\
\hline \multirow{2}{*}{$\begin{array}{l}\text { Basic rocks (composite } \\
\text { sample). }\end{array}$} & \multirow{2}{*}{ 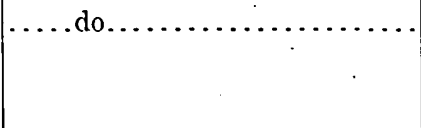 } & 31 & 1. 28 & & \\
\hline & & 296 & 2.3 & 0.7 & \\
\hline \multirow{7}{*}{ 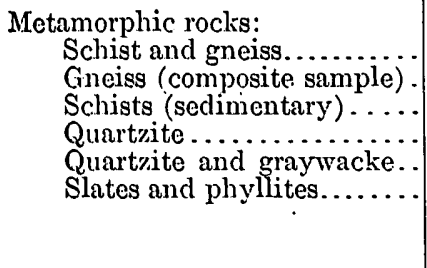 } & & & & & \multirow{7}{*}{$\begin{array}{l}\text { Joly. } f \\
\text { Do.j } \\
\text { Fletcher. } k \\
\text { Do: } k \\
\text { Do. } k \\
\text { Do. } k\end{array}$} \\
\hline & Scotland & 3 & 5.7 & & \\
\hline & Various. & 14 & 2.1 & & \\
\hline & Dublin... & $\begin{array}{l}9 \\
2\end{array}$ & 1. 1 & $\begin{array}{l}\cdots \\
\ldots\end{array}$ & \\
\hline & Various... & 9 & 1. 5 & & \\
\hline & do & 16 & 1.3 & & \\
\hline & & 53 & 1.7 & 0.5 & \\
\hline \multirow{2}{*}{$\begin{array}{l}\text { Sedimentary rocks: } \\
\text { Sandstones (c o m posite } \\
\text { sample). } \\
\text { Sandstones........................... }\end{array}$} & Various. & 39 & ]. 5 & & \multirow{7}{*}{$\begin{array}{l}\text { Joly. }{ }^{j} \\
\text { Fletcher. } k \\
\text { Strutt. }{ }^{k} \\
\text { Joly. } j \\
\text { Büchner. } h \\
\text { Do. } l \\
\text { Fletcher. } k\end{array}$} \\
\hline & .....do... & 24 & 1.5 & & \\
\hline $\begin{array}{l}\text { Sandstones, slates, chalk, } \\
\text { etc. }\end{array}$ & .....do & & & & \\
\hline $\begin{array}{l}\text { Slates and shales (compos- } \\
\text { ite saniple). }\end{array}$ & .....do. & 20 & 1. 5 . & & \\
\hline $\begin{array}{l}\text { Sandstones and sandy } \\
\text { shales. }\end{array}$ & Limburg . . & 8 & 1.7 & & \\
\hline \multirow{3}{*}{$\begin{array}{l}\text { Limestones and marbles... } \\
\text { Limestone, dolomite, chalk. }\end{array}$} & \multirow{3}{*}{ 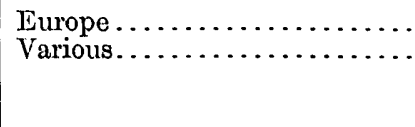 } & 10 & 1.4 & & \\
\hline & & 24 & .8 & & \\
\hline & & 142 & 1. 3 & 0.4 & \multirow{6}{*}{$\begin{array}{l}\text { Joly.j} \\
\text { Do. } \\
\text { Schlundt and Moore. }{ }^{d} \\
\text { Fletcher. } k \\
\text { Moureu and Lepape. } m\end{array}$} \\
\hline \multirow{5}{*}{ 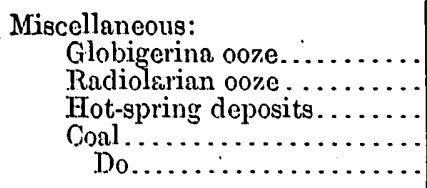 } & Atlantic and Pacific oceans.. & 4 & 3.3 & & \\
\hline & Central Pacific Ocean..... & 2 & 13.1 & & \\
\hline & Yellowstone Park, U. S. A.... & 29 & 2.9 & & \\
\hline & & 1 & 0 & & \\
\hline & Northern France . . . . . . . . . . & 5 & $<.23$ & & \\
\hline
\end{tabular}

Strutt, R. J., On tho distribution of radium in the earth's crust and the earth's internal heat: Roy. Soc. London Proc., ser. A, vol. 77, 472, 1906; vol. 78; p. 150, 1906. For corrected results see Eve, A. S., and McIntosh, D., The amount of radium present in typical rocks in the im-

modiato neighborhood of Montreal: Philos. Mag., 6th ser., vol. 14, p. 231, 1907. Mag., 6 th ser., vol. 18, p. 812,1909

'S mooth, W. F., and Watson, H. E., The radioactivity of Archean rocks from the Mysore State, India: Philos. Mag., 6th ser., vol. 35, p. 206, 1918. pp. 25-26, 1909.

J Joly, J., Radionctivity and geology, pp. 42-60, London, 1909

Buchner, $\mathrm{E}$ H., Investigations of the radium content of rocks: K. Akad. Weten. Amsterdam Proc., vol. 13, pt. 1, p. 359, 1910

a Büchner, is. H., idem, vol. 14, pt. 2, p. 1063,1912 .

i Strutt, R. J. On the radium content of basalt: Roy. Soc. London Proc., ser. A., vol. 84, p. 377, 1910.

f Joly, f., The radioactivity of terrestrial surface materials: Philos. Mag., 6 th ser., vol. 24, p. 694, 1912.

$k$ Fletchor, A. L., On the radium content of secondary rocks: Philos. Mag., 6th ser., vol. 23, p. 279, 1912.

I Büchnor, E. H., op. cit., vol. 13, pt. 2, p. $818,1911$. 
The figures given indicate that the igneous rocks are distinctly richer in radium than the sedimentary rocks, and that the metamorphosed varieties of both classes occupy, as would be expected, an intermediate position. Among the igneous rocks the acidic types are notably the richest, and the intensive studies of Smeeth and Watson in the Mysore State indicate that radium is distinctly subject to magmatic differentiation. Basic varieties are generally poor in radium; the only exceptions noted being the Deccan traps investigated by Joly. Among sedimentary rocks the limestones appear to be somewhat poorer than the sandstones and shales, though the difference is not marked. The deep-sea deposits examined by Joly are exceptionally rich in radium. Hot-spring deposits appear in general to be ing plays an important part in reducing the radium content. In this connection Joly cites a determination of a sample of sand from the Arabian Desert which showed only $0.4 \times$ $10^{-12}$ gram of radium.

The distribution of thorium in the earth's crust has until recently received little attention, and few data regarding it are available. The composite samples of igneous rocks made up by Joly and tested by him for radium have been examined for thorium by Poole, and these determinations, together with a number of others, are given in the accompanying table. In general the distribution of thorium is similar to that of radium; the acidic igneous rocks are richer than the basic, and the argillaceous sediments are richer than the.sandstones and far richer than the limestones.

Thorium content of rocks.

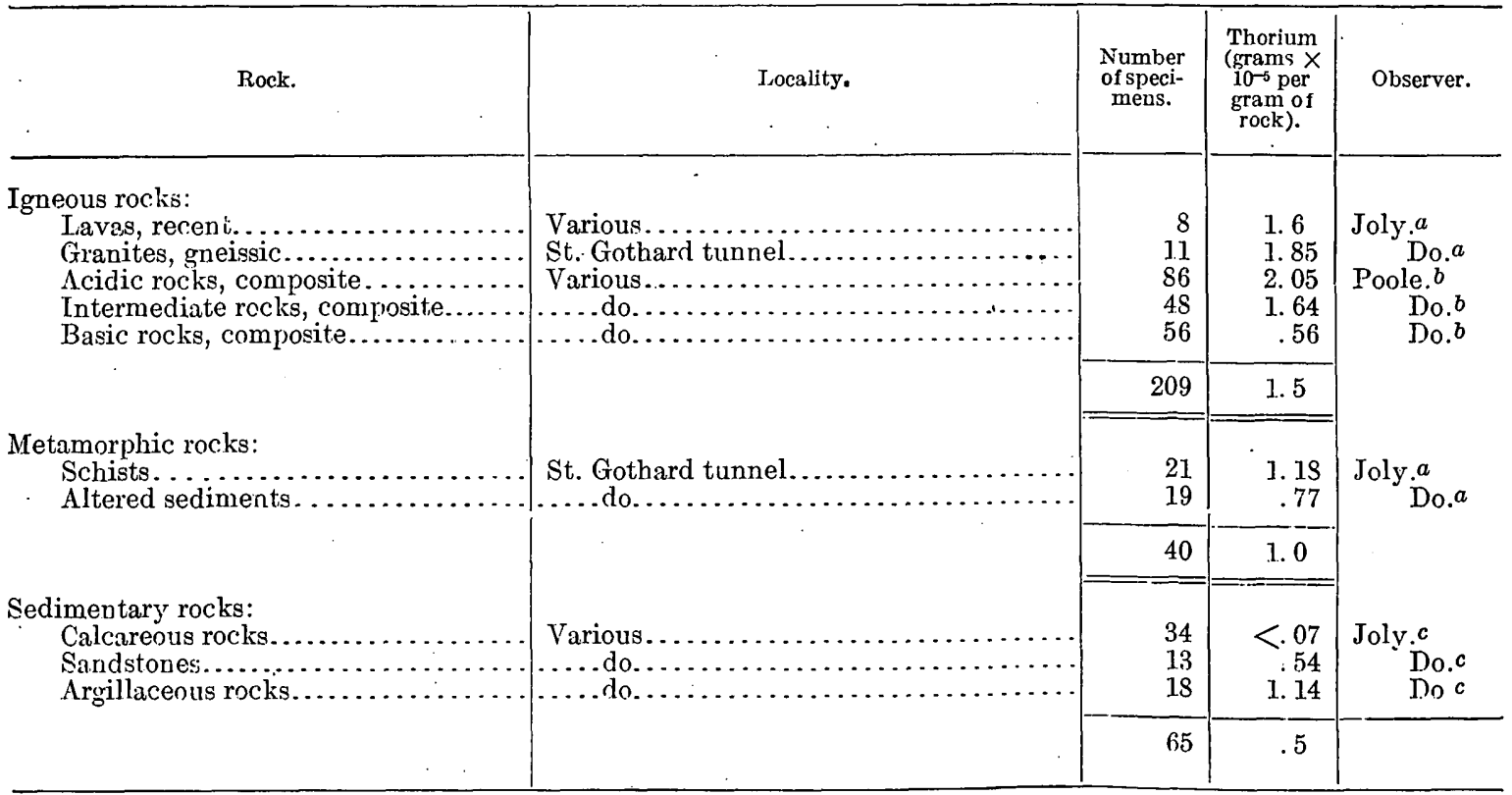

$a$ Joly, J. On the distribution of thorium in the earth's surface materials: Philos. Mag., vol. 18, p. 140, 1909. c Joly, J., The amount of thorium in sedimentary rocks: Philos. Mag., vol. 20, pp. 125, 353, 1910 .

somewhat radioactive, though Schlundt and Moore point out that probably only radium is deposited by the waters, and as it is not sustained by uranium, as in normal rock, its activity soon decreases, and the amount remaining depends chiefly on the age of the deposit. The few specimens of coal examined are surprisingly low in radium. The average radium content of rocks is considerably higher than that of the soils already referred to, a fact which indicates that weather-
As thorium is the parent of its series, whereas radium is simply an intermediate member of the uranium series, the figures cited give little idea of the relative importance of the two groups of radio-elements. As the ratio of radium in equilibrium with uranium is $3.4 \times$ $10^{-7}$, the radium determinations may be calculated in terms of uranium and compared directly with the figures for thorium. The following table shows the thorium content of the four composite samples of igneous rocks deter- 
mined by Poole and the uranium content of uranium and 1.5 of thorium; for metamorphic the same samples calculated from the radium values obtained by Joly:

Thorium and uranium content of igneous rock.

[Grnms $\times 10^{-s}$ per gram of rock.]

\begin{tabular}{|c|c|c|}
\hline & Thorium. & Uranium. \\
\hline $\begin{array}{l}\text { Granites and acidic intrusive and } \\
\text { volcanic rocks }(86) \ldots \ldots \ldots \ldots \ldots \ldots\end{array}$ & 2.05 & 0.89 \\
\hline $\begin{array}{l}\text { Syenites, diorites, trachytes, and } \\
\text { porphyries }(48) \ldots \ldots \ldots \ldots \ldots \ldots\end{array}$ & 1.64 & .78 \\
\hline $\begin{array}{l}\text { Basalts, gabbros, diabases, and no- } \\
\text { rites }(56) \ldots \ldots \ldots \ldots \ldots \ldots \ldots \ldots \ldots \ldots \ldots \ldots \ldots \\
\text { Lavas, Vesuvius }(7) \ldots \ldots \ldots \ldots \ldots \ldots \ldots\end{array}$ & $\begin{array}{r}.56 \\
2.36\end{array}$ & $\begin{array}{r}.38 \\
3.70\end{array}$ \\
\hline
\end{tabular}

rocks 0.5 of uranium and 1.0 of thorium; and for sedimentary rocks 0.4 of uranium and 0.5 of thorium. The average thorium content of all rocks therefore appears to be about twice as great as the average uranium content, and it is very evident that thorium, which until recently was neglected entirely in geophysical calculations, must be taken into account. ${ }^{15}$

Determinations of the radioactivity of a great many spring waters have been made, chiefly in connection with therapeutic studies, but such measurements have little geochemical significance and only a few will be considered

Exclusive of the lavas, the average thorium content in the three groups is $1.42 \times 10^{-5}$, whereas the average uranium content is about half that figure, or $0.68 \times 10^{-5}$. If the general that are rich in the less common mineral

Radioactivity of mineral waters.

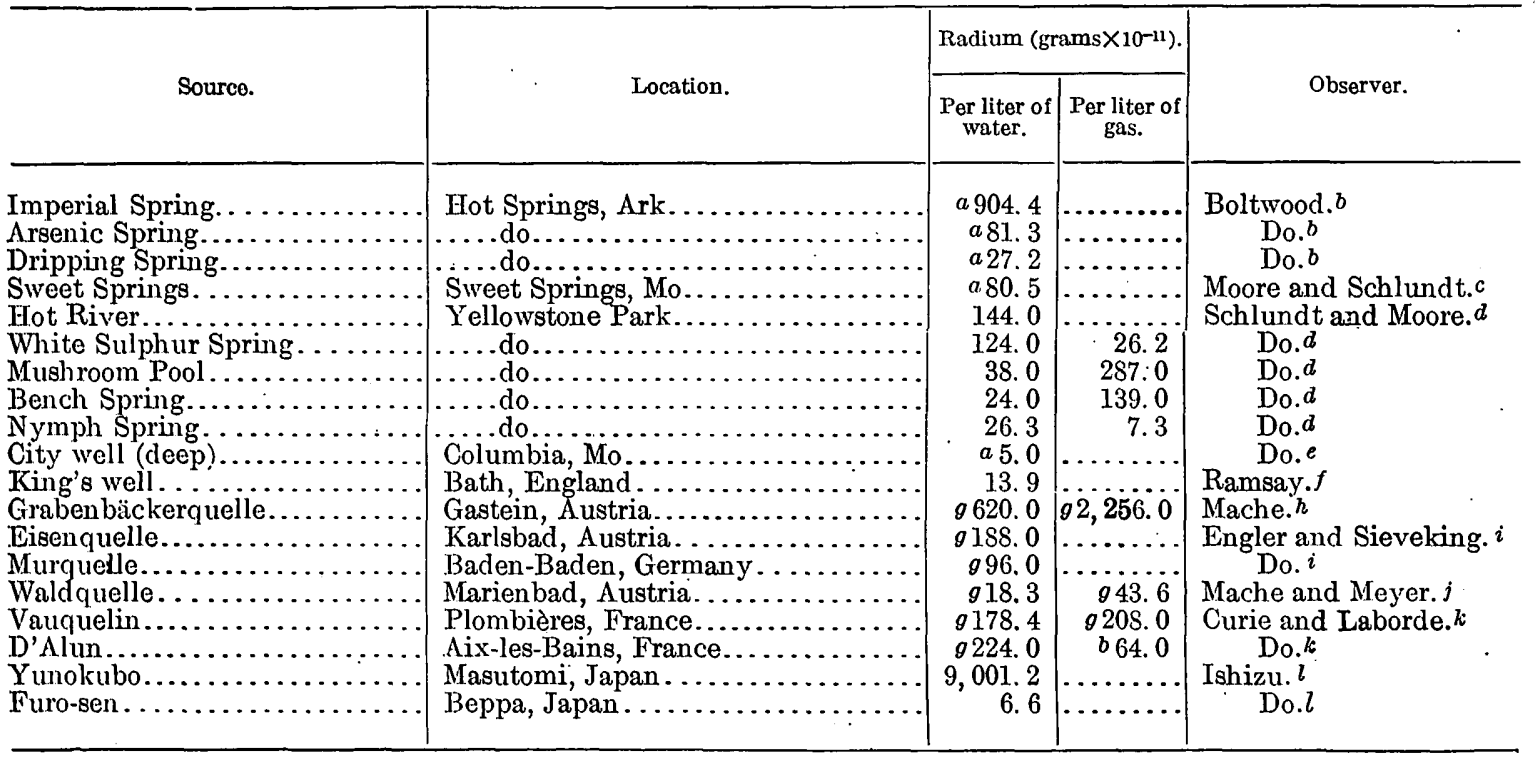

a Originally statod in terms of uranium.

$b$ Boltwood, B. B., On the radioactive properties of the waters of the springs on the Hot Springs Reservation, Hot Springs, Ark.: Am. Jour. Sci., 4 th ser., vol. 20 , p. 128,1905 .

c Moore, R. B., and Schlundt, Herman, On the radioactivity of some natural waters of Missouri: Am. Electrochem. Soc. Trans., vol. 8, p. 291, 1905. d

¿ Schlundt, Horman, and Moore, R. B., Radioactivity of some deep welland mineral waters: Jour. Phys. Chem., vol, 9, p. $320,1905$.

$f$ Ramsay, William, Report on the mineral waters of 13ath: Chem. News, vol. 105, p. 133, 1912

0 Originally stated in terms of electrostatic (Mache) units; here recalculated by the use of the factor 1 gram radium $=2.5 \times 10^{9} \mathrm{Mach} \theta$ units

Mache, H., Ubor dio Radioaktivität der Gasteiner Thermen: K. Akad. Wiss. Wien Sitzungsber., vol. 113, Abt. 2 a, p. $1329,1904$.

Engler, C., and Sieveking, H., Der Radioaktivitat der Mineralquellen: Chem. Zeitung, vol, 31, p. 813, 1907.

Abt. 2 a, p. 355,1905

$k$ Curio, $\mathrm{P}$, and Laborde. A. Sur la radioactivité des gaz qui proviennent de l'eau des sources thermales: Compt. Rend., vol. $142, \mathrm{p} .1462,1906$. $l$ Ishizu, R., The mineral springs of Japan, p. 164, Tokyo, 1915 .

averages of all uranium and thorium determinations given in the tables on pages $55-56$ are considered, the ratios are about the same. Computing the uranium values as before, we find (in grams $\times 10^{-5}$ ) for igneous rocks
0.7 constituents are highly radioactive. The above table contains measurements of the activity of some well-known mineral springs

15 Joly, J., The radioactivity of terrestrial surface materials: Philos. Mag., 6th ser., vol. 24, p. 694, 1912. 
and suffices to show the average degree of activity of such flows. ${ }^{18}$ The gas emitted by such springs is generally richer in radium emanation than the waters. ${ }^{17}$

The radioactivity of petroleum and natural gas has been investigated to some extent and is of particular interest in connection with the occurrence of helium in natural gas. The activity of petroleum was discovered by Burton, ${ }^{18}$ who examined samples of oil from a well near Petrolia, Ontario, and his observations were soon confirmed by Himstedt ${ }^{10}$ and by Elster and Geitel. ${ }^{20}$ Burton concluded that the activity of the oil was due to radium products and suggested that the oil might also contain radium itself. This was denied by Engler, ${ }^{21}$ who examined many samples of European oils and found that although most fresh samples are active, those which have been kept for some years show no activity, indicating that the effects are due to the emanation alone. Hurmuzescu ${ }^{22}$ found the light oils of Rumania to be more active than the heavier ones. Himstedt observed that the emanation is much more soluble in crude oil than in water, and Boyle ${ }^{23}$ found that radium emanation is about 50 times as soluble in refined petroleum oils as in water. Apparently, therefore, the activity of petroleum is due simply to its faculty of absorbing emanation from the surrounding rocks.

16 The papers cited in the table contain a great many more determinations than are here shown. Other measurements are given by Curie, Mme. P., Traité de radioactivité, vol. 2, p. 497, Paris, 1910; Sieveking and Lautenschläger, Über Helium in Thermalquellen und Erdgasen; Physikal. Zeitschr., vol. 13, pt. 2, p. 1043, 1912; Mache, H., and Meyer, S. Über die Radioactivität,österreichischer Thermen: Physikal.Zeitschr., vol. 6, p. 692, 1905; Blanc, G. A., Radioactivity of mineral springs: Philos. Mag., 6th ser., vol. 9, p. 148, 1905; Batelli, A., Occhialini, A., and Chella, S., Untersuchungen über Radioaktivität: Physikal. Zeitschr., vol. 8, p. 65, 1907; Himstedt, F., Über die radioaktive Emanation, der Wasser- und ölquelien: Physikal. Zeitschr., vol. 5, p. 210, 1904; Henrich, F., Untersuchungen über die Thermalquellen von Wiesbaden und deren Radioaktivität: Physikal. Zeitschr., vol. 8, p. 112, 1907.

${ }^{17}$ See Schlundt, H., and Moore, R. B., Radioactivity of the thermal waters of Yellowstone National Park: U. S. Geol. Survey Bull. 395, 1909; Moureu, C., and Lepape, A., La radioactivité des sources thermales de Bagnères-de-Luchon: Compt. Rend., vol. 148, p. 834, 1909; Mache, H., and Meyer, S., op. cit.

${ }^{18}$ Burton, E. F., A radioactive gas from crude petroleum: Philos. Mag.,6th ser., vol. 8, p. 498,1904; Über ein aus Rohpetroleum gewonnenes radioaktives Gas: Physikal. Zeitschr., vol. 5, p. 511, 1904.

${ }^{19}$ Himstedt, F., Über die radioaktive Emanation der Wasser- und Ölquellen: Annalen der Physik, 4th ser., vol. 13, p. 573, 1904; Physikal. Zeitschr., vol. 5, p. 210, 1904.

20 Elster, J., and Geitel, $\mathrm{H}$., Sur la radioactivité de l'atmosphère et du sol: Arch. sci. phyș. nat., 4th ser., vol. 17, p. 13, 1904.

21 Engler, C., Beitrïge zur Chemie und Physik der Erdölbildung: Petroleum Zeitschr., vol. 2, p. 849, 1907.

22 Hurmuzescu, Dragomir, Sur la radioactivité du pétrole: Cong. internat. pétrole, Bucharest, 1907, Compt. rend., Mém., vol. 2, p. 771, 1910.

${ }_{23}$ Boyle, R. W., Note on the solubility of radium emanation in liquids: Roy. Soc. Canada Trans., 3d ser., vol. 3, sec: 3, p. 75, 1909.
Unfortunately, most determinations of the radioactivity of oils are only qualitative or are expressed in arbitrary units, but the following are given in terms comparable to those used in the foregoing tables:

Radioactivity of oil and gas from the Nishiyama field, Japan.:

\begin{tabular}{|c|c|c|}
\hline \multirow{2}{*}{ Well. } & \multicolumn{2}{|c|}{ Radium (grams $\times 10^{-12}$ ). } \\
\hline & $\begin{array}{l}\text { Per liter } \\
\text { of oil. }\end{array}$ & $\begin{array}{l}\text { Per liter } \\
\text { of gas. }\end{array}$ \\
\hline $\begin{array}{l}\text { R. } 22 \text {, Takiya.... } \\
\text { R. } 7 \text {, Nagamine.. }\end{array}$ & $\begin{array}{l}166 \\
144\end{array}$ & 35 \\
\hline
\end{tabular}

a Cited by Ishizu, R., The mineral springs of Japan, p. 189, Tokyo, 1915.

The radioactivity of natural gas was first observed by McLennan, ${ }^{24}$ who tested a number of samples from the Welland and Brantford districts in western Ontario. Gas from the Niagara rocks, at a depth of 500 feet, was more active than any other examined, and gas from the Medina rocks at 900 feet ranked next to the Niagara gas. Samples from the Clinton sand at 750 feet were less active than those from the Medina, and the least active were those from the Trenton limestone at a depth of 3,000 feet. McLennan's observations seem to show an irregular but pronounced decrease in radioactivity with increase in depth, which may be significant in connection with the usual decrease in helium content with increase in depth, as described on pages $23-24$. The radioactivity of a few samples of European natural gas, expressed in arbitrary units, is given on page 34 .

The radioactivity of the atmosphere itself, which was first observed by Elster and Geitel, has been studied by many investigators. ${ }^{25}$ It has been found that both radium and thorium emanation are present in the atmosphere, but that the amount differs in different localities and also varies greatly in relation to meteorologic conditions. In order to eliminate. the meteorologic factors as far as possible and measure the emanation itself, Eve and Satterly used charcoal to absorb the emanation from a known quantity of air for a period of some hours or days, and Ashman condensed the

24 McLennan, J. C., On the radioactivity of natural gas: Nature, vol. 70 , p. $151,1904$.

25 Elster, J., and Geitel, H. op cit. Wegener, Alfred, Untersuchungen über die Natur der obersten Atmosphärenschichten: Physikal. Zeitschr. vol. 12, pt. 1, pp. 170, 214, 1911. Schenk, Richard, Radioaktive Eigenschaften der Luft, des Bodens und des Wassers in und um Halle: Jahrb. Radioaktivität u. Electronik, Band 2, Heft-1, p. 19, 1905. 
emanation directly by means of liquid air. The results are as follows:

Radium emanation in the atmosphere.

\begin{tabular}{|c|c|c|}
\hline Iocnlity. & $\begin{array}{l}\text { Radium } \\
\text { (grams } \times \\
10^{-12} \text { per } \\
\text { cubic } \\
\text { meter). }\end{array}$ & Observer. \\
\hline $\begin{array}{l}\text { Montreal } \ldots \ldots \ldots \ldots \ldots \ldots \ldots \ldots \ldots \\
\text { Cambridge } \ldots \ldots \ldots \ldots \ldots \ldots \ldots \\
\text { Chicago......... }\end{array}$ & $\begin{array}{r}60 \\
100 \\
89\end{array}$ & $\begin{array}{l}\text { Eve. } a \\
\text { Satterly, } \\
\text { Ashman.c }\end{array}$ \\
\hline
\end{tabular}

a Eve, $\Lambda . S$. On the amount of radium emanation in the atmosphere near the earth's surface: Philos. Mag. 6th ser., vol. 16, p. 622, 1908. $b$ Satterly, John, The amount of radium emanation in the atmospher Philos. Mag., 6 th ser., vol. 16, p. 5S4, 1908.

c Ashman, G. C. A' quantitative determination of the radium emanation in the atmosphere: $\Lambda \mathrm{m}$. Jour. Sci., 4 th ser., vol. 26, p. 119,1908

The mean of these determinations is $83 \times 10^{-12}$ grams of radium per cubic meter; and according to Rutherford, ${ }^{26}$ if it is assumed that this quantity is constant up to a height of 10 kilometers, the quantity of radium necessary to keep up the supply is about.1. gram per square kilometer of the earth's surface. Sanderson ${ }^{27}$ found that the air drawn from deep in the soil at New Haven contains emanation equivalent to $2.4 \times 10^{-13}$ grams of radium and $1.35 \times 10^{-0}$ grams of thorium per cubic centimeter.

A number of measurements of the radium content of sea water have been made, but the results are not satisfactorily concordant. Joly, ${ }^{28}$ on the basis of 24 determinations, concluded that the average radium content is $0.017 \times 10^{-12}$ grams per cubic centimeter, indicating a total oceanic content of 20,000 tons of radium, whereas Eve, ${ }^{29}$ who examined six samples from the Atlantic, obtained an average value of only $0.0009 \times 10^{-12}$ gram per gram. Joly, ${ }^{30}$ in a more recent calculation, has adopted the intermediate figure $0.004 \times 10^{-12}$ gram of radium per cubic centimeter of sea water, which he finds represents roughly the difference between the total quantity of adium brought into the ocean by the denudation of igneous rocks and the total quantities now found in sedimentary rocks and oceanic sediments.

\footnotetext{
${ }^{20}$ Rutherford, E., op. cit., p. 634 .

27? Sanderson, J. C., The probable influence of the soil on local atmos. pheric radioactivity: $\mathrm{Am}$. Jour. Sci., 4th ser., vol. 32, p. 169, 1911.

28 Joly, J., Radioactivity and geology, p. 46, London, 1909; On the radium content of sea water: Philos. Mag., 6th ser., vol. 18, p. 396, 1909.

${ }_{89}$ Eve, A. S., On the amount, of radium present in sea water: Philos. Mag., 6th ser., vol. 18, p. 102, 1909.

${ }^{20}$ Joly, J., Radioactivity of terrestrial surface materials: Philos. Mag., Gth ser., vol. 24, p. 704, 1912.
}

ESTIMATES OF HELIUM PRODUCTION.

From the foregoing data on the distribution of the radio-elements in the earth's crust it is possible to obtain a general idea as to the quantity of helium produced in the normal course of radioactivity. Although the estimate is necessarily based on incomplete data, the value of the conclusions is enhanced by the fact that two entirely independent calculations led to fairly concordant results. The first calculation given below is based on the rate of loss of the earth's heat, and the second on the observed distribution of the radio-elements in the rocks.

If the rocks in the interior of the earth contain as much radium as the surface materials, the heat so generated would be many times as much as the earth gives off; hence it is necessary to assume also that most or all of the radium is concentrated in a comparatively thin surface layer, probably only 8 or 10 miles thick. Many authorities, however, believe that all the heat lost annually by the earth is compensated by radioactive processes, and this assumption furnishes a convenient basis for a calculation of the volume of helium so generated.

The simplest calculation may be based on the common though erroneous assumption that radium and its immediate products are the only elements concerned. If the average geothermal gradient is taken to be $1^{\circ} \mathrm{F}$. in 64 feet, and the average conductivity of the rocks to be 0.0058 , the amount of heat lost annually per square centimeter of the earth's surface is 41.4 calories. $^{31}$ As 1 gram of radium yields 134.4 calories an hour, ${ }^{32}$ or $1,177,344$ calories a year, it is evident that there must be $3.5 \times 10^{-5}$ gram of radium beneath each square centimeter to maintain this loss of heat. One gram of radium emits 158 cubic millimeters of helium a year; and there are $51 \times 10^{17}$ square centimeters in the earth's surface. Then $\left(3.5 \times 10^{-5}\right) \times 158 \times\left(51 \times 10^{17}\right)=28,203 \times 10^{12}$ cubic millimeters of helium. That is, 28.2 million cubic meters of helium is produced annually by the decay of radium on the assumption that the loss of heat from the earth is compensated by that generated by radium.

81 This figure was adopted in 1882 by the committee on underground temperatures of the British Association for the Advancement of Science and according to C. E. Van Orstrand, who has made a careful study of geothermal gradients, the data that have since been gathered indicate that it is sufficiently near correct for the purposes of this calculation.

${ }^{82}$ Rutherford, E., Radioactive substances and their radiations, p. 581, Cambridge, 1913. 
As some heat is generated by other members of the uranium series, however, and as thorium is even more widely distributed than uranium, it is obvious that a more nearly correct result may be obtained if all the radio-elements are taken into account. As shown on page 57, the average ratio of thorium to uranium in igneous rocks is about 2 to 1 ; in other words, each average gram of radioactive material consists of two-thirds of a gram of thorium, in equilibrium with its products, and one-third gram of uranium, also in equilibrium. Thorium in equilibrium generates $2.7 \times 10^{-5}$ calories an hour, and uranium $7.7 \times 10^{-5}$ calories an hour; ${ }^{33}$ hence the average gram of radioactive material generates $4.4 \times 10^{-5}$ calories an hour, or 0.385 calories a year. If we take the loss of heat from the earth at 41.4 calories per square centimeter, it is evident that there must be 107.5 grams of the thorium-uranium mixture beneath each square centimeter, or 35.8 grams of uranium and 71.6 grams of thorium. From the data given by Rutherford ${ }^{33 a}$ it follows that the helium generated by these quantities of uranium and thorium is $616 \times 10^{-5}$ cubic millimeters a year, which, multiplied by the number of square centimeters in the earth's surface $\left(51 \times 10^{17}\right)$, gives 31.4 million cubic meters of helium per year.

The second method of calculation is based on the observed quantity of the radio-elements in surface rocks and on the assumption that these elements occur only in an outer layer of the earth's crust 10 miles thick. In such a calculation the metamorphic and sedimentary rocks and the oceanic sediments in sea water may be neglected, the average value for the igneous rocks alone being used. From the tables on pages 56 and 57 the average value of uranium per gram of igneous rock is seen to be $0.7 \times 10^{-5} \mathrm{gram}$ and that of thorium $1.5 \times 10^{-5}$ grams. One gram of uranium in equilibrium emits $11 \times 10^{-5}$ cubic millimeters of helium a year, and 1 gram of thorium $3.1 \times 10^{-10}$ cubic millimeters; hence the total helium generated per year per gram of rock is $12.4 \times 10^{-5}$ cubic millimeters. Assuming the average density of the outer layer of the earth's crust to be 2.5, we may compute that the weight of this layer is $10,421,615 \times 10^{9}$ grams per cubic mile, from which it follows that 12,923 cubic centimeters or 0.456 cubic foot of helium is generated per

${ }^{33}$ Rutherford, E., op. cit., p. 583.

33a Idem, p. 560 . year per cubic mile. The surface of the earth is $1.97 \times 10^{8}$ square miles, and a layer 10 miles deep contains about $19.7 \times 10^{8}$ cubic miles. The total helium generated annually in this layer is thus $8.98 \times 10^{8}$ cubic feet, or 25.4 million cubic meters.

If it is desired to estimate the helium produced in a restricted field, where the sedimentary rocks form a layer about 1 mile thick, the average uranium value for a block 10 miles deep may be reduced to $0.67 \times 10^{-5}$ gram and the thorium value to $1.4 \times 10^{-5} \mathrm{grams}$. On the other hand, the density of the rocks may be taken at 2.7, and the resulting figure is 0.465 cubic foot of helium per year per cubic mile, which is only very slightly larger than the average figure derived above.

The foregoing estimates are all based partly on assumptions and of course may be considerably in error. Becker ${ }^{34}$ for example, maintains that only about 25 per cent of the heat lost by the earth is generated by radioactivity, and if his view is correct the first two estimates would be reduced to 7 or 8 million cubic meters. Nevertheless, it seems safe to conclude that somewhere between 8 and 30 million cubic meters (282 to 1,060 million cubic feet) of helium is generated annually by radioactive processes. The bearing of this fact on the origin of the helium in natural gas is discussed on page 62 .

\section{THEORIES OF THE ORIGIN OF HELIUM IN NATURAL GAS.}

\section{REVIEW OF DATA.}

In the foregoing pages the writer has endeavored to describe the geologic conditions under which helium-bearing natural gas occurs, and to review rather fully the occurrence of helium in other materials, in order to permit the reader to form his own judgment as to the most plausible hypothesis of the source and origin of the helium. At present this is all that can be done, for although the data are abundant in some respects, they are deficient in others and the evidence is not wholly concordant. It is apparent that considerable geochemical work will be necessary before any one hypothesis can be accepted; and it is the writer's purpose, in discussing the several hypotheses in the following pages, to point

${ }^{34}$ Becker, G. F., Isostasy and radioactivity: Geol. Soc. America Bull., vol. 26, p. 201, 1915. 
out some of the ways in which the problem can best be attacked.

Before proceeding to the discussion of hypotheses it will be convenient to present, by way of recapitulation, the data already given.

\section{REVIEW OF THE OCCURRENCES OF HELIUM.}

\section{Observed Occurrences.}

\section{A. IN NATURAL GAS.}

(a) United States.-Helium constitutes from 0.5 to 2 per cent of certain nitrogen-rich natural gases in Kansas, Oklahoma, and Texas and occurs in smaller proportions in the gases of many other districts. The gases richest in helium are confinerl to strata of upper and middle Pennsylvanian age and occur close to the surface, the helium content usually decreasing with increasing depth. Gases containing from 0.25 to 0.5 per cent of helium occur in the lower Pennsylvanian of the Mid-Continent area, in the Mississippian and Silurian of Ohio, and in the Cretaceous of Montana, although in general the pre-Pennsylvanian gases are poor in helium, and the Cretaceous and Tertiary gases carry only traces or none at all. The helium-rich areas are not marked by igneous activity or by unusual structural conditions. There is no evidence as to whether or not the rocks in these districts are abnormally radioactive.

(b) Europe.-Helium has been detected in European natural gas in proportions as great as 0.38 per cent. The richest gas was found in a deep test hole in Alsace, probably in lower Mesozoic strata; the Tertiary gas in this locality is very poor in helium, and the Tertiary gases of -Germany, Austria, Italy, and Transylvania are also poor. The helium content of these gases appears to vary roughly as their radioactivity.

\section{IN MINERALS AND ROCKS.}

A great variety of minerals have been found to contain at least traces of helium, and apparently only a few species are helium-free. Minerals rich in the radio-elements may contain several times their own volume of helium; ordinary rock-forming minerals are usually poor. In general the amount of helium in a mineral is proportional to its radioactivity and increases with age, indicating that the helium has been generated by the decay of the radio-elements; but certain beryls contain far more helium than can be explained in this way.

$$
\text { c. IN MINE GASES. }
$$

The gases of French and Belgian coal mines carry helium, and though the proportion is small the total volume emitted yearly is large. The coals themselves are very poor in the radio-elements, and helium is evidently not being generated in the coal nearly as fast as it is being emitted. There is, therefore, no evidence to connect the helium in the mine gases with radioactivity.

D. IN MINERAL-SPRING GASES.

The gases of many European mineral springs contain helium in proportions as great as 10 per cent. The volumes of helium emitted yearly by some of the springs represent all the helium that would be generated yearly by many tons of radium; hence thiis helium, like that in mine gases, probably represents the overflow or leakage of a great underground accumulation. Furthermore, the proportion of helium in the gases bears no relation to their radioactivity.

\section{E. IN VOLCANIC GASES.}

Small proportions of helium occur in the gases of certain Italian fumaroles, where there is no evidence to connect it directly with radioactivity.

\section{F. IN THE ATMOSPHERE.}

Helium constitutes 0.0004 per cent of the atmosphere near the earth's surface. In the upper atmosphere its proportion is greater.

$$
\text { G. IN CELESTIAi، Bodies. }
$$

Helium is a prominent constituent of the solar chromosphere and of many nebulae and stars, though the radioelements have not been identified with certainty in any celestial bodies.

\section{Inferred OcCurrences.}

As the radio-elements generate helium in the course of their spontaneous disintegration, each occurrence of radioactive material connotes the presence of helium; but the radio-elements, because of their activity, can be detected in far smaller quantities than can the helium to which they give rise. The radio-elements are very widely disseminated through terrestrial materials, being present in minute proportions in practically all minerals and rocks, in the atmosphere, and in river and ocean water. Most petroleum and natural gas apparently contains some radium emanation. The helium generated by the radioelements disseminated through ordinary rocks amounts to almost half a cubic foot per year per cubic mile of rock.

From the foregoing evidence certain broad conclusions may be drawn as follows:

1. The helium in most minerals is probably of radioactive origin; and as the radio-elements are disseminated through ordinary rocks in proportions sufficient to generate large volumes of helium in the course of a few million years, much of the helium in rocks has probably also originated through radioactivity.

2. As helium is very prominent in celestial bodies, whereas the radio-elements are not, it is probable that helium can and does occur in the universe entirely apart from the radio-elements, and that these elements may be regarded as compounds of helium and lead which form only under certain conditions. Accordingly, much of the helium in the earth may never have been associated with the radio-elements and may be primordial helium.

As the volumes of helium in some mineral-spring and mine gases are so large that incredible quantities of the radio-elements would be necessary to generate the helium as fast as it is emitted, it is probable that there are great stores of helium underground, the leakage or overflow of which appears in the spring and mine gases. These stores of "fossil" helium may be accumulations of the small vol; umes liberated by the disintegration of radio-elements through geologic time or they may in large part be pri- 
mordial. The helium in natural gas may therefore be primordial or it may have been liberated through the decay of the radio-elements. As a great volume of helium is contained in the atmosphere there is the third possibilitywhich is not concerned with the ultimate origin of the element--that the helium in natural gas has in some way been derived from the atmosphere.

\section{DERIVATION THROUGH RADIOACTIVITY. FOSSIL HELIUM.}

Since it was discovered that the alpha rays given off by the radio-elements are helium atoms it has been tacitly assumed by most scientists that all helium is the product of radioactivity. Even Moureu, who has plainly shown that the helium emitted by certain mineral springs can not be the product of contemporaneous radioactivity and who therefore regards it as "fossil" helium, apparently believes that this fossil helium is simply the accumulation of the small volumes of the gas liberated by the radioelements during geologic time. It was natural, therefore, that Cady and McFarland, when they announced their discovery of helium in natural gas, should suggest that it originated in the decay of the minute quantities of radium disseminated through the rocks.

It is obvious that the helium in natural gas presents a problem different from that of the helium given off by mineral springs, for the emission of gas by the springs is a natural phenomenon which has been proceeding at least for many centuries; whereas the release of helium from the natural gas reservoir is artificial, its rate depending on the number of gas wells drilled. It would therefore be absurd to suppose that the supplies of helium in natural gas are being replenished underground as fast as they are brought to the surface, and it must be recognized at the outset that the helium in natural gas represents the accumulation of ages and is, to use Moureu's term, fossil helium.

\section{DERIVATION FROM NORMALLY DISSEMTNATED} RADIO-ELEMENTS.

In order to test the theory briefly suggested by Cady and McFarland, that the helium has been derived from the disintegration of the radio-elements disseminated in normal quantities through the rocks, an examination of conditions in the Petrolia field, in Texas, will be convenient. 'According to independent estimates by E. W. Shaw and the writer (see p. 88), the Petrolia field originally contained about 120 billion cubic feet of natural gas, and as the percentage of helium in the gas is 0.93 , the total helium must have been a little over 1 billion cubic feet. The producing area at Petrolia is about 10 square miles, but the gas probably represents the accumulation from an area of about 25 square miles. Let us assume for the moment that the helium in the gas represents all the helium generated in this area to a depth of 4 miles beneath the gas sands-in other words, in a block of 100 cubic miles of rock. It has been shown (p. 60) that the radio-elements disseminated through a cubic mile of the normal or average rock yield, by their disintegration, about 0.456 cubic foot of helium a year. The annual production of helium in 100 cubic miles is thus about 46 cubic feet, and the production in 25 million years would about equal the volume now found in the Petrolia field.

Two objections to the validity of this calculation at once present themselves. In the first place the basic assumption made by Strutt and others who attempt to calculate the age of minerals from the helium ratio is that most of the helium generated in a mineral remains in that particular grain or crystal during geologic time. The writer does not wholly agree with this view, for the mere existence of enormous accumulations of helium in natural gas in regions removed from unusual structural disturbances is sufficient to show that helium does migrate (unless, indeed, it is assumed that the helium has actually formed in the gas sands themselves); yet, on the other hand, if helium were free to leave the mineral as fast as it is formed and migrate upward, it is evident that the rocks near the surface everywhere would be saturated with helium. It is probable, therefore, that helium ordinarily does not migrate very far from the point of its origin and that little of the helium generated in the dense rocks several miles deep can have found its way into the gas sands. This difficulty might be lessened somewhat by assuming a shallower block of strata and a longer lapse of time, but it would still constitute a grave objection.

The other argument against this calculation is the self-evident one that normal conditions should bring about normal results-in other words, if the helium at Petrolia is supposed to 
have been generated by the radio-elements normally distributed through the rocks, why should not the same volumes of helium accumulate everywhere? Most natural gas contains at least a trace of helium, some of which has very probably been generated in the normal course of radioactivity; but the high percentage in the Petrolia gas, as well as in that of the Kansas fields, plainly indicates special conditions of some kind. So far as known, the conditions of accumulation in the helium-rich gas fields are no more favorable than in fields that produce gas free from helium, nor are there any known fissures or channels along which the helium could have risen from great depths. If helium is to be ascribed to radioactivity, therefore, it is necessary to postulate a local deposit of the radio-elements in each helium-rich district.

\section{DERIVATION FROM LOCAL DEPOSITS OF THE} RADIO-ELEMENTS.

As 1 ton of uranium in equilibrium yields about 1 cubic foot of helium a year, 40 million tons of uranium (or about 120 million tons of the Joachimsthal pitchblende) would yield in 25 million years the total estimated volume of helium at Petrolia. It is evident, however, that some of the helium would remain in the mineral grains in which it is formed, and that more would undoubtedly remain entangled in the rock close to the point of its origin; hence it is necessary to assume a deposit capable of generating considerably more helium than the gas sands themselves actually contain. On the other hand, it does not appear necessary to adopt the extreme view held by Strutt, that practically all the helium remains in the particles in which it was formed-in fact, if this view is adopted, it must be assumed that the helium has been generated in the gas sands. If it is supposed that only a half or a third of the helium generated has found its way into the gas sands, the size of the deposit that would have to be assumed at Petrolia is not incredibly large, and in all the other helium-bearing fields it would be smaller.

There appear to be no great geologic difficulties in the way of assuming such deposits, aside, of course, from the fact that there is no direct evidence of their presence. In the Kansas area it may be supposed that a uranium or thorium deposit existed in the old land mass from which the middle Pennsylvanian sedi- ments were derived and that the débris from this deposit was laid down within a fairly small area. Monazite, for example, which is rich in thorium, is not uncommon as a minor constituent of clastic rocks and is locally abundant enough to form deposits of monazite sand. Or it might be supposed that uranium has since been introduced into the rocks by ascending solutions and precipitated as the secondary minerals carnotite or autunite. The carnotite ores of Colorado occur in sedimentary rocks rich in organic matter, which has evidently been a factor in their formation, and similar occurrences in the helium-bearing areas would not be surprising. It is not necessary to assume that these deposits are concentrated in a small area; it would be more reasonable, in view of the extent of the helium-bearing area in Kansas to suppose that the uranium minerals are widely disseminated through the rocks, and are perhaps only 50 or 100 times as abundant as in the normal or average rock of the earth's crust.

On the other hand, it might be supposed that the igneous rocks which doubtless underlie the Kansas area at a depth of less than 2 miles contain deposits of pitchblende, and that the helium liberated by these deposits has risen and mingled with the hydrocarbon gas formed in the sediments above. The presence of the buried granite ridge in the western part of the Kansas area might be regarded as supporting.this view, for uranium minerals are more abundant in granite than in other igneaus rocks. However, in addition to the fact that this granite lies not within but chiefly to the northwest of the helium-rich area, the practical absence of helium in all the deeper gases suggests that it originated not far beneath the base of the Kansas City group, the lowest horizon at which it is found in notable quantity. The fact that the helium occurs through a stratigraphic range of about 2,000 feet above this horizon might be taken to indicate that the active deposits are also scattered through this zone, or it might simply be supposed that the helium originated in the Kansas City group and has in part risen to upper beds.

In the Ohio area the helium is found at two widely separated horizons, the Berea and the Clinton sand, and the helium content. of the gases below the Clinton sand is not known; hence in this district there is no evidence against the assumption that the helium has risen from 
considerable depths. At Petrolia the helium is known only at one horizon in the upper Pennsylvanian, and the deeper gases have not been tested, though gases from middle and lower Pennsylvanian strata in the Ranger district, 100 miles to the south, are poor in helium.

From a geologist's point of view, therefore, it would appear most reasonable to assume in the Kansas area an extensive disseminated or very lean deposit of uranium or thorium ore in the middle Pennsylvanian strata; at Petrolia a somewhat richer deposit at the same or a slightly higher horizon; and in Ohio a deposit in the Silurian to supply the Clinton sand, and perhaps another in the Devonian or Mississippian to supply the Berea.

These hypothetical deposits would then explain the occurrence of helium in certain fields and its absence in others, and also the fact that, in the Kansas area at least, the helium is confined to a certain group of formations and is absent in the gases both above and below that group.

There are certain other fragments of indirect evidence which offer some support to the general theory that helium is derived from the radio-elements. Because of the time element involved, the theory helps to explain the absence of helium in practically all the younger (Cretaceous and Tertiary) gases tested. Furthermore, the natural gas of Petrolia and Canada and the oil from many ather localities are radioactive, apparently owing to the great solubility of radium and thorium emanation in petroleum. (See p. 58.) This suggests that petroleum may have some effect in concentrating the emanations by selective absorption, thus causing helium to be liberated in the oil itself. Except for Ramsay's statement that helium is insoluble in benzene there are no data as to the solubility of helium in oil; but it is probable that helium is at least only slightly soluble and that it would therefore be expelled from the oil and would mingle with the hydrocarbon gases almost as fast as it was formed. A third bit of evidence which may possibly bear on the subject is Van Orstrand's discovery ${ }^{35}$ that the geothermal gradients in the Newkirk field, in northern Oklahoma, and in the Ranger district, in . Texas, are very high, as would be expected if extensive deposits of the radioelements were present. These districts do not

${ }^{35}$ Van Orstrand, C. E., personal communication. produce gas very rich in helium, and there are no data as to the character of the gradient in the rich helium fields themselves, but an unusually high gradient even in the vicinity of those fields is of interest.

There are two other points which are more difficult to explain on this theory, or indeed on any other-the concentration of the helium at shallow depths, at least in the Kansas area, and the general association of the helium with nitrogen. The most reasonable explanation for the concentration of the helium near the surface in the Kansas area would be, according to this theory, the fact that the radioactive deposits also happen to lie near the surface. The only other explanation would appear to be that the helium, being very light, migrates upward through the rocks rather faster than the other gases. If so, it follows that the helium is constantly escaping from the shallow gas sands into the atmosphere, for if it is free to migrate through the denser rocks below it must certainly be capable of passing through the more pervious surface rocks. This explanation is not very satisfactory, for if helium has been constantly escaping a far greater volume than that still remaining in the sands must have been dissipated. Moreover, in the Ohio area there is no such concentration of helium near the surface, for the Clinton gas at a depth of about 2,300 feet carries as much helium as the Berea gas at about 500 feet.

The association of helium with nitrogen is difficult to account for. It has been suggested by Lind that the nitrogenous compounds present in organic shales may be destroyed by radioactivity and that the nitrogen so liberated would mingle with the helium generated in the same process. It is known, however, that water is decomposed by radioactivity, with the liberation of hydrogen, yet no hydrogen occurs in the helium-bearing gases, and if the radioactivity is not sufficient to decompose water in perceptible amounts, it is difficult to understand why the nitrogen compounds should be so extensively broken up. Similarly, helium occurs in mineral-spring gases, which are usually rich in nitrogen but in which no hydrogen is reported, so that little weight can be attached to this suggestion until definite evidence of the effects of radioactivity on nitrogenous compounds can be adduced. Another fact that militates against the view that the nitrogen in 
the gas is of organic origin is that Kansas and Ohio oils contain very small proportions of the nitrogen gases. California oil, on the other hand, is unusually rich in nitrogen, yet the California gas contains little nitrogen and no helium. (See pp. 37, 96.) However, the gas given off by uranium and thorium minerals is usually rich in nitrogen, which thus seems to have some general though unexplained relation with the radio-elements.

In order to raise the foregoing speculations to the rank of a definite hypothesis certain forms of evidence must be collected. Among the pertinent questions to be answered are the following:

1. Do the helium-bearing gas sands or the rocks adjoining them contain notable quantities of the radio-elements?

2 . Is the geothermal gradient abnormally high in the helium areas, thus affording indirect evidence of the presence of radioactive deposits?

3. Are the oil-field waters or the waters of mineral springs in the helium areas strongly radioactive, and do they carry helium?

4. Is the petroleum radioactive, and if so is this due simply to dissolved emanations or does the ash of the petroloum carry uranium or thorium?

5 . Is there any relation between the radioactivity of the gas and its helium content?

6. Does radioactivity rapidly destroy the nitrogenous compounds in oil shale, liberating free nitrogen?

7. Are the pores of the rocks beneath the helium-bearing gas sands largely filled with helium?

8. Is helium soluble in crude petroleum and is it more soluble in some varieties than in others?

DERIVATION FROM FAINTLY RADIOACTIVE ELEMENTS.

Discovery of the fact that potassium and rubidium are faintly radioactive has led several observers to suggest that other elements may also emit radiations. Potassium and rubidium themselves apparently emit only beta rays and therefore do not generate helium, but there is a possibility that other elements may emit alpha radiations of low velocity. As described on page 14, the radioactivity of a substance is ordinarily measured through its property of ionizing gases, this property being due in part to the very high speed at which the active particles are expelled. Rutherford states that if alpha particles (helium atoms) were expelled at a velocity of about half that at which they are given off by uranium they would not cause ionization and hence would not be detected by the ordinary methods of examination. In other words, there is a possibility that certain common rock-forming elements may emit alpha radiations at low velocity and may therefore generate helium."

In this connection it will be recalled that Strutt interpreted the occurrence of large volumes of helium in some potash minerals as evidence that potassium generates helium, though the fact that no alpha rays from potassium have ever been detected casts doubt on this view. Similarly the anomalous volumes of helium found in beryls were formerly thought to indicate that the element glucinum is radioactive, but this idea was disproved by Piutti, who found no helium in six specimens of phenacite, which is richer in glucinum than beryl itself.

Recently the hypothesis that helium in natural gas may result from the disintegration of elements not known to be radioactive has been suggested by R. B. Moore, ${ }^{36}$ who is familiar with the conditions under which the helium occurs and whose extensive work in the field of radioactivity deserves special consideration. There is, of course, no direct evidence for this suggestion, but Dr. Moore proposes to investigate the matter experimentally, and his results will be awaited with interest. If it can be shown that common rock-forming elements generate helium, it would probably be easy to explain the source of the helium in natural gas, though it may be pointed out that the reverse difficulty might then arise-the problem of explaining the absence of helium in other areas.

Our knowledge of radioactivity is still fragmentary, and it will not be surprising if future discoveries compel us to modify our present ideas considerably. Clarke ${ }^{37}$ suggested many years ago that the chemical elements have been developed by a process of evolution from simpler forms of matter, and the more recent discovery of changes in the opposite direction, such as the disintegration of uranium into simpler bodies, offers consider-

${ }_{36}$ Personal communication.

37 Clarke, F. W., Evolution and the spectroscope: Pop. Sci. Monthly, January, 1873.

$10135^{\circ}-21-5$ 
able support to this view. Dr. Moore, in discussing with the writer his theory that other elements may prove to be radioactive, sums up his attitude in the words "I can not help thinking that something is going on that science knows nothing of at the present time, and that the presence of helium [in natural gas] can not be accounted for by anything that comes within the scope of our present knowledge." The possibility that other elements also disintegrate can not be ignored, though the helium in natural gas should not be ascribed to such action unless positive evidence can be adduced or unless all other hypotheses are proved inadequate.

\section{PRIMORDIAL HELIUM.}

In contrast with the views of those who ascribe all helium to radioactive processes is the theory developed by Becker, Clarke, and others that some and perhaps much of the helium in the globe is primordial and has had no connection with radioactivity. It is, of course, difficult to adduce positive or direct evidence in favor of such a theory, and it therefore rests on certain broad deductions, chief among which are the following:

1. The prominence of helium and the apparent absence of uranium and thorium in celestial bodies indicate that helium can and does occur in the universe apart from the radio-elements, which may therefore be regarded as .combinations of helium and some other element, apparently lead.

2. The disintegration of uranium and thorium is attended by the emission of an enormous quantity of heat; hence their formation must be accompanied by the absorption of heat and could take place only under conditions of great temperature and pressure. Conditions favorable to their formation doubtless existed in the earlier stages of the cooling earth and may exist in the interior of the earth to-day.

3. If uranium and thorium are to be regarded simply as combinations of helium and lead, there is no reason to suppose that all the helium in the earth entered into this combination, for it is clear that all the lead did not.

These conclusions, though not susceptible of actual proof, are none the less forceful and deserving of consideration. The concept of primordial helium removes the quantitative difficulties which confront all hypotheses of derivation from the radio-elements. The existence of helium in mineral-spring and mine gases in volumes far larger than can be explained by the radioactivity of these gases indicates that there are large accumulations of helium underground, and these accumulations can be explained at least as well by the primordial theory as by any theory of radioactive origin. The same is true of the helium in volcanic gases. On the other hand, the helium in most minerals is obviously derived from the radio-elements, and most minerals evidently contain a large proportion of all the helium that has been generated within them; hence it may be argued that the great bulk of all helium produced by radioactirity is confined in the rocks close to the point of its origin and that it can not have entered into the great accumulations which find their escape in various natural gases. This is, in fact, the view held by Strutt and many others who, though apparently ascribing all helium to radioactivity, ignore the evidence of natural gases and contend that helium for the most part remains in the mineral grains in which it is formed.

Another difficulty confronting those who oppose the concept of primordial helium is that of explaining the great volume of helium in the atmosphere. C. E. Van Orstrand has calculated from the figures given by Jeans (p. 52) the total volume of helium in the atmosphere and finds it to be $58 \times 10^{12}$ cubic meters. As shown on page 60 , the total volume of helium generated annually in the earth by the disintegration of the radio-elements is probably somewhere between 8 million and 30 million cubic meters. At the maximum rate all the helium in the atmosphere would therefore be formed in 2 million years; the minimum rate would require $7 \frac{1}{4}$ million years. It is generally admitted, however, that only a small proportion of the helium generated can have migrated through the rocks and escaped into the atmosphere, for very large volumes are known to be entangled in the rocks and to be trapped in accumulations of various natural gases. Even assuming that helium is produced at the rate of 30 million cubic meters a year, therefore, it seems probable that a longer time would be required for the accumulation and escape of all the helium in the atmosphere than most geologists are willing to allow for the age of the earth. 
Broadly considered, the theory of pri-/ should therefore be found accompanying the mordial helium thus has many advantages, though its detailed application to the helium in natural gas is more difficult. In order to explain the occurrence of helium in some localities and not in others, it is necessary to postulate special structural conditions of some kind which would permit the belium to rise from below. The only known unusual structural feature in any of the helium areas is the buried granite ridge in the Mid-Continent region (see pp. 22,35), but the fact that the deep gases nearest the granite are poor in helium indicates that little significance can be attached to this feature. All the other helium-bearing gas fields, except the Havre field, are located in regions of gentle structure which are remote from igneous activity; and on the other hand several fields examined which are close to areas of structural disturbance and igneous action produce gas that is practically free from helium. (See p. 35.) Furthermore, the stratigraphic distribution of the heliumincluding its absence not only in the Permian and Mississippian gas of the Mid-Continent area but also in practically all Cretaceous and Tertiary gases-is very difficult to explain.

On the other hand, the primordial theory is not incompatible with the common occurrence of helium near the surface and with its usual association with nitrogen. As already noted, if the concentration of helium near the surface is ascribed to its tendency to migrate upward it must be admitted that the helium is constantly escaping from the shallowest sands into the atmosphere; and according to this view the volumes of helium involved are so large that they can be explained only by the primordial theory or some other which postulates an almost illimitable supply.

The association of helium with nitrogen in natural gas, in mineral-spring gases, and in the gases given off by rocks would also be reasonable according to the primordial theory, especially as it is very difficult to see how the nitrogen in natural gas can have been derived from the petroleum or from other organic sources. Some observers have concluded that the common occurrence of nitrogen in deep earth gases is due to the decomposition of nitrides in the earth's interior; others, like Moureu, adopt an opposite view, pointing out that nitrogen is a chemically inactive gas and truly inert gases, helium, argon, krypton, etc. Argon and neon in very small proportions have been detected in some of the helium-bearing gases of Kansas, but unfortunately no quantitative determinations have been published and definite evidence on this point must await further work.

\section{ATMOSPHERIC . HELIUM.}

The great supply of helium in the atmosphere and the common occurrence of heliumrich gases in shallow strata naturally suggest that the helium in natural gas may be of atmospheric origin. Owing to the lack of evidence this view can at present be regarded only as conjectural. Two possibilities present themselves-that the helium, nitrogen, argon, etc., represent the inactive residue of air that has been entrapped in the sediments; or that these gases have been absorbed by the decaying organic matter from which the petroleum is derived and have been later concentrated in some manner.

When sediments are laid down offshore a certain amount of air is probably trapped in the interstices; and if these sediments should be raised above sea level during a period of aridity, when the ground-water level is low, and then resubmerged and covered by further deposits, a large quantity of air might be permanently trapped..$^{38}$ The oxygen and carbon dioxide in this air would be chemically fixed as oxide and carbonate, and some of the nitrogen might also enter into combination, leaving a residue of nitrogen, helium, argon, etc. This theory has the following definite objections: (1) The formation of nitrogenous compounds under ordinary temperature and pressure seems improbable. (2) Air contains about 2,300 times as much argon as helium, and although argon is strictly an inert gas, differing from helium chiefly in its greater solubility in water, the natural gases of Kansas apparently contain far less argon than helium. (3) The Permian sediments of Kansas and Oklahoma are supposed to be in part continental deposits laid down under arid conditions which were presumably very favorable to the entrapping of air, yet the Permian gases are very poor in helium.

s8 This theory has been developed and discussed by Frank Reeves (The absence of water in certain sandstones of the Appalachian oil fields: Econ. Geology, vol. 12, p. 354, 1917). 
The organic matter from which petroleum is derived may under some conditions be exposed to the air before its burial in the sediments. ${ }^{39}$ Certain of the fatty compounds that are formed and destroyed during the decay of organic matter and its conversion into oil ${ }^{40}$ may have the power of absorbing helium with proportionately smaller quantities of nitrogen and the rare gases. After the burial of the organic débris, its conversion into petroleum and the destruction of the active compounds would permit the helium to escape. This theory is of course founded solely on conjecture, but it might be tested without great difficulty by experimental work on the absorption of helium by various fatty and other organic compounds.

\section{CONCLUSIONS.}

Of the theories discussed in the foregoing paragraphs the following seem the most plausible and are supported by the greatest number of data. (1) That the helium is derived from deposits of uranium or thorium, probably disseminated through the strata not far beneath the horizons at which the helium-bearing gas occurs. (2) That the helium is primordial and is derived from deep-seated sources. The theory that ascribes the helium to elements not yet known to be radioactive and the theories that regard it as atmospheric helium are not yet supported by any definite evidence, though the former especially should be borne in mind as a distinct possibility.

In favor of the theory of derivation from deposits of uranium and thorium the following main points may be cited. (1) The existence of such deposits is not unreasonable from a geologist's point of view. (2) If it is admitted that considerable helium can escape from the mineral in which it forms and migrate upward, the size of the assumed deposits would not be incredible. (3) Such deposits would account for the areal and also the stratigraphic distribution of the helium, including its absence in younger (Cretaceous and Tertiary) gases. (4) Radium and thorium emanations are highly soluble in petroleum, which may therefore tend to concentrate these elements and their descendants. In opposition to the theory it may be argued (1) that there is no evidence,

${ }^{39}$ This view has been developed by Murray Stuart (The sedimentary deposition of oil: India Geol. Survey Rec., vol. 40, pt. 4, pp. 320-333, 1910).

40 Engler, C., Beiträge zur Chemie und Physik der Erdölbildung: Petroleum Zeitschr., vol. 2, pp. 850-853, 1907. direct or indirect, for assuming the existence of radioactive deposits other than the presence of the helium itself, and (2) that there is some doubt as to the extent to which helium escapes from the minerals in which it is formed, and if only a small proportion escapes incredibly large deposits of the radio-elements must be postulated.

In favor of the theory of primordial helium, (1) there is an excellent evidence that helium exists in the universe apart from the radioelements, and it is therefore very probable that some of the helium in the earth has never been associated with them; (2) the concept of primordial helium removes all the quantitative difficulties which confront other theories. The chief argument against this theory is that it does not explain the areal or the stratigraphic distribution of the helium-bearing gas.

In many respects the first theory appears preferable to the writer, the chief objection being that its major premise-the existence of radioactive deposits-is pure assumption. If direct or indirect evidence of the existence of such deposits could be gathered this theory would be the logical one to accept. If, however, no evidence of deposits large enough to produce the results observed can be obtained and if the other hypotheses suggested also fail through lack of evidence, the theory of primordial helium is arrived at by a process of elimination.

\section{CHIEF SOURCES OF HELIUM-BEARING NATURAL} GAS.

\section{GENERAL OCCURRENCE.}

In the course of the present investigation practically all commercial supplies of natural gas in the western part of the Mid-Continent oil and gas region were sampled and tested for helium. Little attention was paid to the gas produced in the eastern part of the region, for, as shown by numerous complete analyses, the gas of that locality is low in nitrogen and therefore presumably too poor in helium to be of commercial value. All supplies of gas large enough to be of economic value in southern Oklahoma and in Texas, Wyoming, the Dakotas, Montana, Washington, and California were also investigated, and a few samples were collected in Louisiana and other States.

Except in the Vinton County field, Ohio, practically no work was done in the great 
CHIET SOURCES OF HELIUM-BEARING NATURAL GAS.

Appalnchian and northern interior oil and gas regions, which contribute about 70 per cent of all the gas produced annually in the United States. This neglect was due partly to lack of time and partly to the fact that the many analyses of gas from those regions that have been made and published during the last 50 years show uniformly low nitrogen content and therefore indicate that the gas is poor in helium. It is believed that if gas of low heating value - that is, rich in nitrogen and heliumwere being produced in any of the eastern fields the fact would be known or would have been discovered incidentally during the investigation. The prospects of discovering further supplies of gas similar to that produced in Vinton County are therefore believed to be slight, though it must be recognized that this conclusion is based on inference rather than on detailed observation.

In the course of the investigation about 325 samples of gas, most of them collected by members of the Geological Survey, were tested for helium. 'The results of the tests and all particulars regarding the source of the samples and the supply of the gas available are presented in tabular form on pages 96-109. The tests made by Cady and McFarland in 1906 have also been included in the tables, which thus present a concise summary of our present knowledge regarding the distribution, occurrence, and available supply of helium-bearing natural gas in the United States.

The location of the fields from which the samples were taken is shown on Plates I and III and figure 5 (p. 29), and the general geology of the helium-bearing districts has been discussed. In the following pages brief descriptions of the more important helium-bearing gas fields will be given, with special reference to the location and economic relations of the fields, the volume of gas available, and the probable duration of the supply. No attempt will be made, however, to describe all the field's from which samples were collected, or even to give complete geologic descriptions of the fields which are at present the chief potential sources of supply. The statements as to developments of course refer to the time at which this paper is written.

\section{MID-CONTINENT REGION.}

ELMDALE FIELD.

The Elmdale gas field is in Chase County, Kans., about 5 miles west of Cottonwood Falls. The field as at present dereloped lies mostly south and east of Elmdale, or in the southeast corner of T. 19 S., R. 7 E., but there are also three isolated groups of successful wells some miles north and northeast of the field. Although the surface rocks in this general district are normally of Permian age, a large and prominent anticline or dome has brought the upper Pennsylvanian strata to the surface in the vicinity of Elmdale. The anticline, which represents a structural elevation of about 200 feet, has a north-south diameter of about 12 miles and an east-west diameter of about 9 miles; its center is in the valley of Cottonwood River, about 3 miles southwest of Elmdale. Despite the size and altitude of this fold it has not been productive of oil, and two deep wells. near Elmdale encountered granite at a depth of about 1,900 feet.

Several dozen gas wells have been drilled on or close to the anticline. Gas is found at three horizons, in beds known as the 150-foot sand, the 350 -foot sand, and the 580-foot sand. Wells have been drilled to the 150 -foot sand at a number of farmhouses, where the gas is used directly for domestic purposes. The initial pressure is said to be about 17 pounds to the square inch and the flows small, but the wells are long-lived. The 350-foot and 580foot sands have been developed on a commercial scale by the local gas company, which supplies about 300,000 cubic feet: a day to Cottonwood Falls, Strong City, and neighboring towns. The flow of the wells is comparatively small, and the "settled" pressure is only 20 to 30 pounds. The sands appear to be productive nearly everywhere throughout a large area, however, and it is claimed by local engineers that it would be possible to develop a production of 8 to 10 million cubic feet a day, provided all three sands were tapped.

Samples of gas collected from the 350-foot and 580-foot sands showed, respectively, 0.35 and 0.50 per cent of helium, and a sample collected by Cady and McFarland from the 150foot sand in 1906 showed 0.56 per cent. The 
analyses thus indicate that the gas is not especially rich in helium, despite its shallow depth and the location of the field in the same general belt as the helium-rich Augusta and Eldorado fields, to the south.
ELDORADO FIELD.

LOCATION.

The Eldorado field, which is in the central part of Butler County, Kans., is one of the most productive oil fields in the Mid-Continent

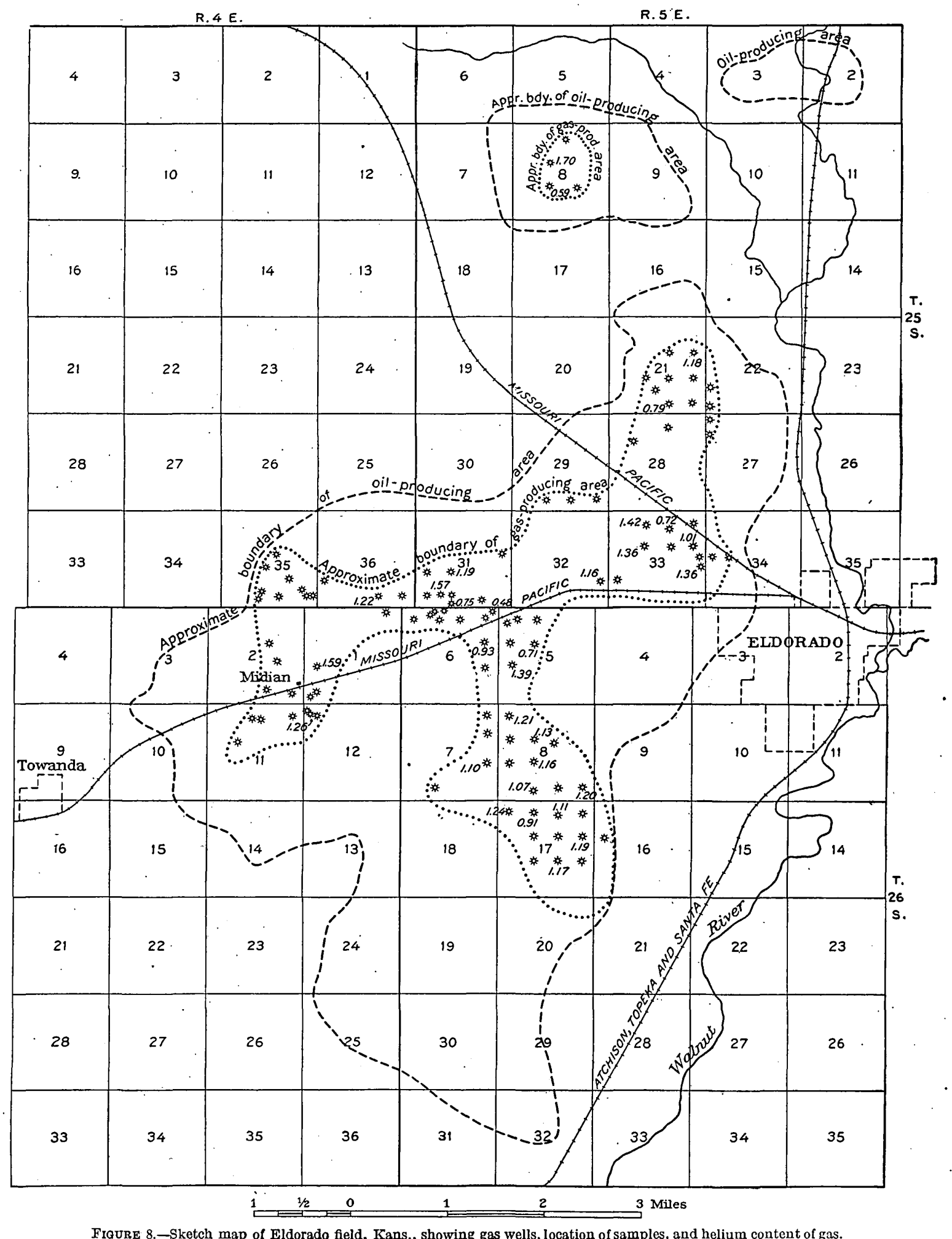

Figure 8.-Sketch map of Eldorado field, Kans., showing gas wells, location of samples, and helium content of gas. 
region and is at present one of the chief potential sources of helium-bearing natural gas. The field lies chiefly in T. 25 S., R. 5 E., but extends some distance into T. 26 S., R. 5 E., and T. 24 S., R. 4 E. (See fig. 8.) The town of Eldorado, on the eastern edge of the field, is at the junction of the Missouri Pacific and Atchison, Topeka \& Santa Fe railroads. The town has a population of about 15,000 and the nearest city, Wichita, about 30 miles to the west, has a population of about 60,000 and is an important railroad center.

GEOLOGIC OUTLINE.

The productive sands in the Eldorado field are of Pennsylvanian and Mississippian age, the highest occurring near the top of the Pennsylvanian and the lowest in Mississippian and probably in places in older rocks. The highest producing sand is encountered at a depth of 650 feet and according to Fath ${ }^{41}$ occurs in the lower part of the Wabaunsee group. It is productive only in the northeastern part of the field, where it yields considerable oil but practically no gas. The field's output of gas is obtained from the next lower productive sands, which occur at average depths of $900,1,200$, and 1,475 feet. The sands at 900 and 1,200 feet are fairly persistent throughout the producing area, but they are zones or groups of sands which individually are lenticular and discontinuous. These zones, which yield the great bulk of all the gas produced in the field, occur in the Shawnee, Douglas, and Lansing groups. The main oil zone is encountered at an average depth of 2,500 feet and occurs in Mississippian rocks corresponding to the Boone limestone. In places it probably extends downward into older rocks. This zone yields the bulk of the oil produced in the field, and a great many oil wells have therefore penetrated the overlying gas sands. In most of these wells the gas has been mudded off, but the gas pressure in a sand penetrated by so many wells is naturally. affected, despite precautionary measures.

The Eldorado field lies on a prominent anticline, on which there are many irregular cross folds and minor wrinkles. According to Fath, the distribution of hoth oil and gas is closely related to the structure; the gas sands are pro-

"Fath, A. E., report on the Eldorado oil and gas field, Kans. (in preparation). ductive only in the highest parts of the fold, and the oil sands are productive over a much larger area which extends from the crest of the fold well down its flanks. (See fig. 8.) Owing to the lenticular character of the sands and to the variation in their porosity, however, neighboring gas wells may have very different capacities.

QUALITY OF THE GAS.

As shown by the tests of 33 samples (see p. 98), the gas of the Eldorado field ranges in helium content from 0.48 to 1.70 per cent. Only two samples, however, show less than 0.71 per cent, and the average of all the samples is 1.12 per cent. Nineteen samples of gas from the 900-foot zone show an average helium content of 1.20 per cent, and 13 samples from the 1,200 foot zone an average of 1.01 per cent.

The Eldorado gas varies considerably in composition, and there appear to be no marked and constant differences between the gases. from different sands. The general quality of the gas is shown by the following representative analyses:

Analyses of gas of Eldorado field, Kans.

\begin{tabular}{|c|c|c|c|}
\hline & $\begin{array}{l}\text { 900-foot } \\
\text { zone. }\end{array}$ & $\begin{array}{l}\text { 1,200-foot } \\
\text { zone. }\end{array}$ & $\begin{array}{l}\text { 1,400-foot } \\
\text { zone. }\end{array}$ \\
\hline $\begin{array}{l}\text { Carbon dioxide }\left(\mathrm{CO}_{2}\right) \ldots \ldots \\
\text { Oxygen }\left(\mathrm{O}_{2}\right) \ldots \ldots \ldots \\
\text { Methane }\left(\mathrm{CH}_{4}\right) \ldots \ldots \ldots \ldots \\
\text { Ethane }\left(\mathrm{C}_{2} \mathrm{H}_{6}\right) \ldots \ldots \ldots \\
\text { Residue }\left(\mathrm{N}_{2}, \text { etc. }\right) \ldots \ldots\end{array}$ & $\begin{array}{r}0.56 \\
\therefore .00 \\
54.58 \\
3.33 \\
41.53\end{array}$ & $\begin{array}{r}0.10 \\
.14 \\
62.68 \\
11.82 \\
25.26\end{array}$ & $\begin{array}{r}0.12 \\
.10 \\
31.36 \\
12.78 \\
55.64\end{array}$ \\
\hline $\begin{array}{c}\text { Heating value } \text { (British } \\
\text { thermal units).............. }\end{array}$ & $\begin{array}{l}100.00 \\
584\end{array}$ & $\begin{array}{l}100.00 \\
811\end{array}$ & $\begin{array}{l}100.00 \\
524\end{array}$ \\
\hline
\end{tabular}

VOLUME AND DURATION OF THE GAS SUPPLY.

Although the Eldorado field is still comparatively young, having been opened late in 1915, its gas resources have been heavily drawn upon in the last four years and are now probably about two-thirds exhausted. The maximum daily production of about 20 million cubic feet was reached at the end of 1916, when the combined open flow of all the wells was about 60 million cubic feet. In May, 1918, the daily production was about 10 million and the total open flow about 25 million cubic feet. The entire production of the field is used for drilling and pumping the oil wells, but it constitutes only about two-thirds of the volume required for this purpose. 
The first wells in the field had an average rock pressure of 465 pounds to the square inch but in May, 1918, the average pressure of all the wells in the field had fallen to 140 pounds. This rapid decline in pressure, which is shown graphically in figure 9 , is due chiefly to the fact that the wells have been allowed to produce from 30 to 50 per cent of their open flow, though a contributing factor has doubtless been the unavoidable waste of gas caused by the fact that the gas sands have been punctured by so many wells drilled for oil. It will be noted, however, that the greater part of the decline in pressure took place in 1916, the period during which most of the gas wells were drilled and when also the daily production was production, provided the wells are not made to yield too heavily. If the daily production of the field had been reduced to 4 million cubic feet in the middle of 1918 , this production could probably have been maintained for at least three years. On the assumption that the average helium content of the gas is 1.12 per cent, this would represent a daily production of 44,800 cubic feet of helium.

It will be noted that the curve in figure 9 shows a slight upward trend in the first part of 1918. This is due to the bringing in of several large gas wells on a small dome then recently discovered at the north end of the field. Although the gas-bearing territory in the main field has now been practically all drilled, there

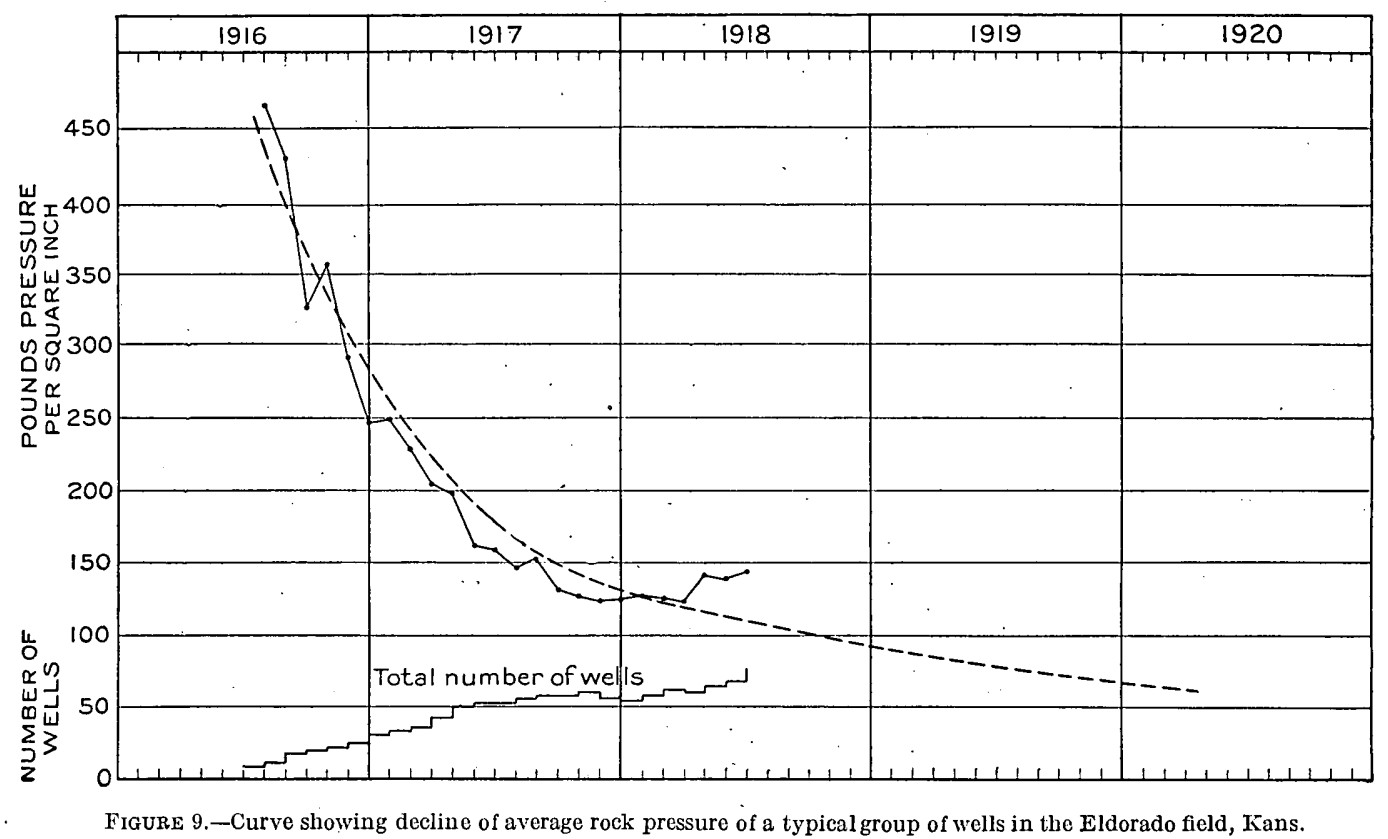

largest. From the middle of 1917 to the middle of 1918, when the drilling became less active and the daily production was reduced to 10 or 12 million cubic feet, the decline in pressure became very moderate.

As the rock pressure declines the open flow and therefore also the production diminishes; but as the production decreases the decline in pressure becomes less rapid. In the later stages of the life of a field the curve of pressure decline therefore becomes flatter, and a small production may be maintained for a comparatively long period. It is evident from figure 9 that the Eldorado field has entered this stage and that during the next two or three years the is a possibility that other small additional supplies will be discovered, and that the life of the field will be correspondingly increased.

\section{AUGUSTA FIELD.}

LOCATION.

The Augusta field is in the southwestern part of Butler County, Kans., its north end being only about 5 miles south of the southern limit of the Eldorado field. The Augusta field lies chiefly in Tps. 27 and 28 S., R. 4 E. The town of Augusta, which has a population of about 1,500 , is in the east-central part of the field. It is situated on the St. Louis-San Francisco and Atchison, Topeka \& Santa Fe railroads. field may be relied on to furnish a moderate (See fig. 10.) 
GEOTOGIC OUTIINE.

The general geology of the Augusta field is similar to that at Eldorado, and the producing zones are roughly equivalent to those already described for that field. The 650-foot zone, however, which yields only oil in the Eldorado field, carries at Augusta a "wind gas" very rich in helium. The maingas sands form a zone ranging in depth between 1,400 and 1,600 feet. Individual sands can not be traced for great distances, and the gas seems to occur irregularly through this zone, rather than at several distinct horizons, as at Eldorado. The principal oil sands lie at depths of about 2,000 to 2,400 feet.

The Augusta field is on a large anticlinal fold which represents a southwestern continuation of the Eldorado anticline. The Augusta fold, like that at Eldorado, is irregular, and it consists of at least two fairly distinct anticlines. The larger one, which is known as the main Augusta anticline, lies chiefly in T.28S., R. 4 E. It yields a large proportion of the oil produced

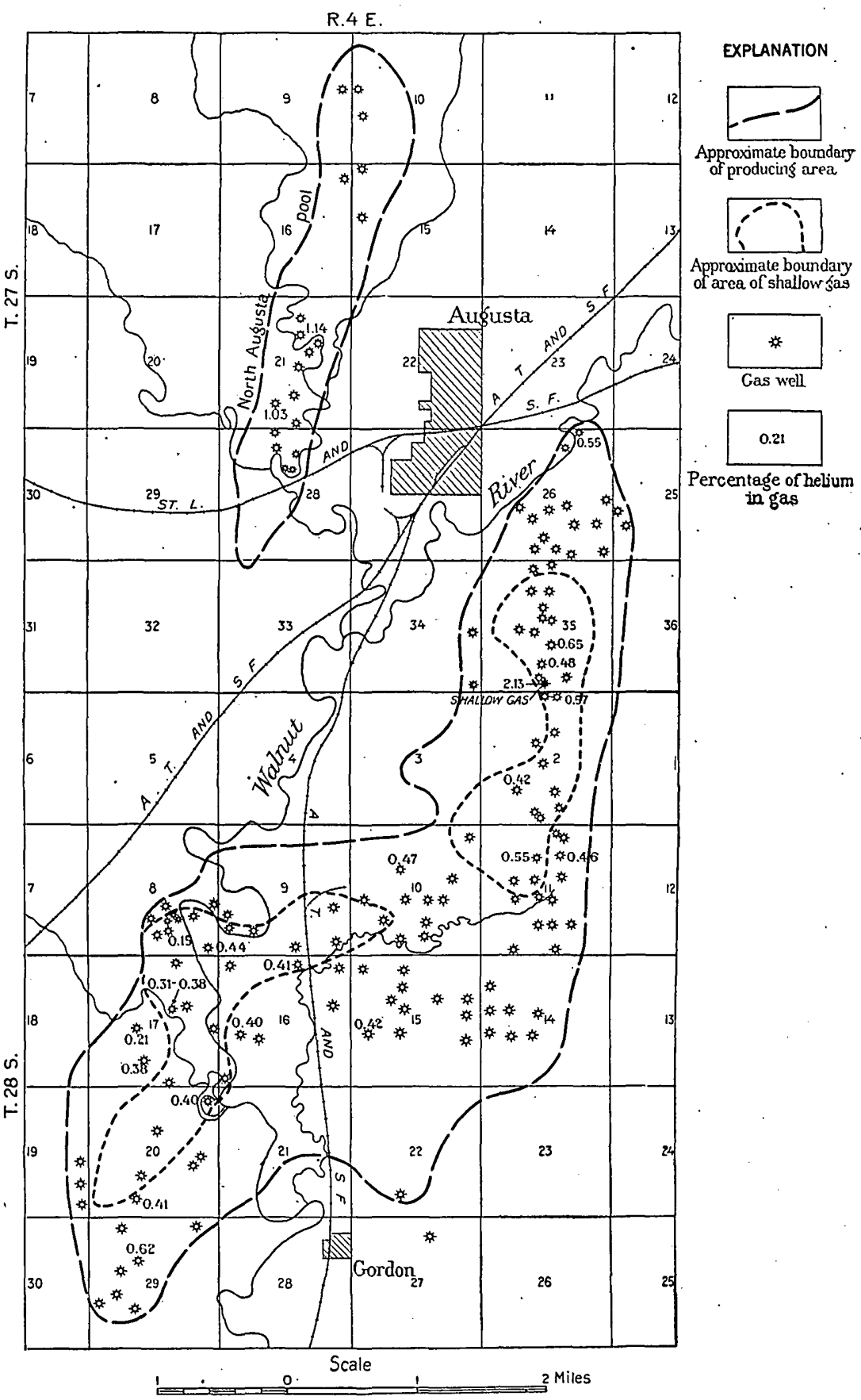

FIGURE 10.-Sketch map of Augusta field, Kans., showing gas wells, location of samples, helium content of gas, and areas in which the shallow gas rich in helium occurs.

in this field and at present practically all the gas. / low zone (450 to 650 feet) contained 1.94 and The smaller fold, which is known as the North 2.13 per cent of helium. Two samples of the Augusta anticline, is in the central part of T. 27 gas occurring at depths of 1,200 to 1,400 feet on S., R. 4 E., and is separated from the main the North Augusta anticline, in T. 27 S., R. 4 E., anticline by a structurally low and barren area. showed 1.03 and 1.14 per cent of helium. The QUATITY OF THE GAS.

Twenty-six samples of Augusta gas have been tested for helium, with the results shown on page 98. Two samples of gas from the shal- $\mid$ between 0.16 and 0.65 per cent, though only 
three samples showed less than 0.38 per cent, and the average of the 22 samples is 0.43 per cent.

There are therefore in the Augusta field three distinct types of gas containing 2.04, 1.09, and 0.43 per cent of helium. The richest and the poorest of these gases occur at different depths on the main anticline, which comprises the central and southern parts of the field. The intermediate gas occurs at about the same depth and horizon as the poorest gas but on the North Augusta anticline. It is interesting to note that the gas produced on this anticline thus differs greatly in helium content from that produced in the main field and resembles the Eldorado gas; and it is said, furthermore, that the North Augusta oil resembles the Eldorado oil in gravity and composition more closely than the oil of the main Augusta field. .

The shallow gas carrying about 2 per cent of helium is very high in nitrogen, as shown by analysis 17 , page 39 . The gas produced in the North Augusta field is on the average only slightly higher in nitrogen than that of the main field, though containing about twice as much helium. This is shown by the following analyses, kindly furnished by Prof. H. C. Allen:

Analyses of gas from the Augusta and North Augusta fields, Kans.

\begin{tabular}{|c|c|c|c|c|}
\hline \multirow[b]{2}{*}{$\begin{array}{l}\text { Carbon dioxide }\left(\mathrm{CO}_{2}\right) \ldots \\
\text { Oxygen }\left(\mathrm{O}_{2}\right) \ldots \ldots \ldots \ldots \\
\text { Methane }\left(\mathrm{CH}_{4}\right) \ldots \ldots \ldots \ldots \\
\text { Ethane }\left(\mathrm{C}_{2} \mathrm{H}_{6}\right) \ldots \ldots \ldots \ldots \\
\text { Higher hydrocarbons.... } \\
\text { Residue }\left(\mathrm{N}_{2}, \text { etc. }\right) \ldots \ldots \ldots\end{array}$} & \multicolumn{2}{|c|}{ Augusta. } & \multicolumn{2}{|c|}{ North Augusta. } \\
\hline & $\begin{array}{r}0.21 \\
.00 \\
76.48 \\
12.60 \\
.44 \\
10.26\end{array}$ & $\begin{array}{r}0.32 \\
.12 \\
63.32 \\
13.45 \\
.13 \\
22.63\end{array}$ & $\begin{array}{r}0.00 \\
.31 \\
50.22 \\
21.32 \\
.00 \\
28.15\end{array}$ & $\begin{array}{r}0.07 \\
.19 \\
63.92 \\
5.67 \\
.19 \\
29.96\end{array}$ \\
\hline $\begin{array}{l}\text { Heating value (British } \\
\text { thermal units)............ }\end{array}$ & & & 100.00 & $\begin{array}{r}100.00 \\
719\end{array}$ \\
\hline
\end{tabular}

QUANTITY OF SHALLOW GAS AVAILABLE.

As shown in figure 10 the shallow gas containing about 2 per cent of helium occurs only in certain parts of the field, being apparently confined to two areas, aggregating about 2,000 acres, on the main Augusta anticline. These areas accupy the two highest points on the anticline, and their shape and extent are determined almost entirely by structural conditions. Within these areas, however, the distribution of the gas is irregular and is evidently controlled by variations in the porosity of the sand, for out of about 200 deep oil and gas wells drilled in the shallow-gas territory only about 75 encountered volumes of this gas large enough to be noted and reported by the drillers. The volumes reported range between a few thousand and $3 \frac{1}{2}$ million cubic feet daily, with an average of perhaps 400,000 cubic feet. The rock pressure of this gas has never been gaged, though an inconclusive test made by the writer suggests that it is probably between 50 and 75 pounds to the square inch.

As the shallow gas consists so largely of nitrogen that it is practically incombustible, no attempts have been made to produce it, but owing to the drilling of so many deeper wells through its horizon a considerable volume of the gas has doubtless escaped. The Empire Gas \& Fuel Co., in a noteworthy spirit of conservation, has taken pains to mud off or seal this horizon in all its wells, but most of the other operating companies have taken no precautions to prevent the gas from escaping. On the other hand, the variable porosity of the sand itself has evidently prevented very extensive loss of the gas, for the volumes reported in wells drilled recently average about as large as those in the early wells. Owing to the irregular distribution of the gas, to the lack of information as to the rock pressure, and to the fact that an indeterminate quan tity has escaped it is impossible to estimate the total volume still in the sands, but it is probably little more than half a billion cubic feet.

QUANTITY OF DEEP GAS AVAILABLE.

The Augusta field, which was opened late in 1913, produced up to the middle of 1918 between 30 and 35 billion cubic feet of gas, all of which was derived from the group of sands occurring at depths between 1,400 and 1,600 feet. The original rock pressure was slightly over 400 pounds to the square inch, but in July, 1918 , the average pressure was about 140 pounds. At that time the daily production of the field was almost 7 million cubic feet, and the total open flow was about 20 million cubic feet.

The gas resources of the North Augusta anticline are now almost exhausted, and the present output of the field is derived almost wholly from the main anticline. The field is now well outlined, and there is little prospect of the discovery of new supplies, although a few 
additional wells can yet be drilled. A study of the curve of rock-pressure decline indicates that unless water troubles become too serious the field should be capable of producing an average of 3 to 4 million cubic feet a day until some time in 1921...

The comparatively low helium content of this deeper gas renders it unfavorable as a source of helium, but if it were mixed with the shallow gas in proportions of 3 to 1 the average helium content of the mixture would be about 0.8 per cent.

DEXTER-OTTO DISTRICT. LOCATION.

The Dexter-Otto area comprises that part of eastern Cowley County, Kans., shown in figure 11. A very prominent anticline traverses this area and extends both north and south beyond the territory shown on the map. 'Two deep oil wells, many shallow gas wells, and a number of dry holes have been drilled on or near the axis of the fold. There are three areas in which gas is produced-the vicinity of Dexter, an area 2 miles north of Otto, and an area 5 miles southeast of Otto. In all these areas the gas is rich in helium, carrying from 0.5 to 1.9 per cent, but the present supply is small, and the

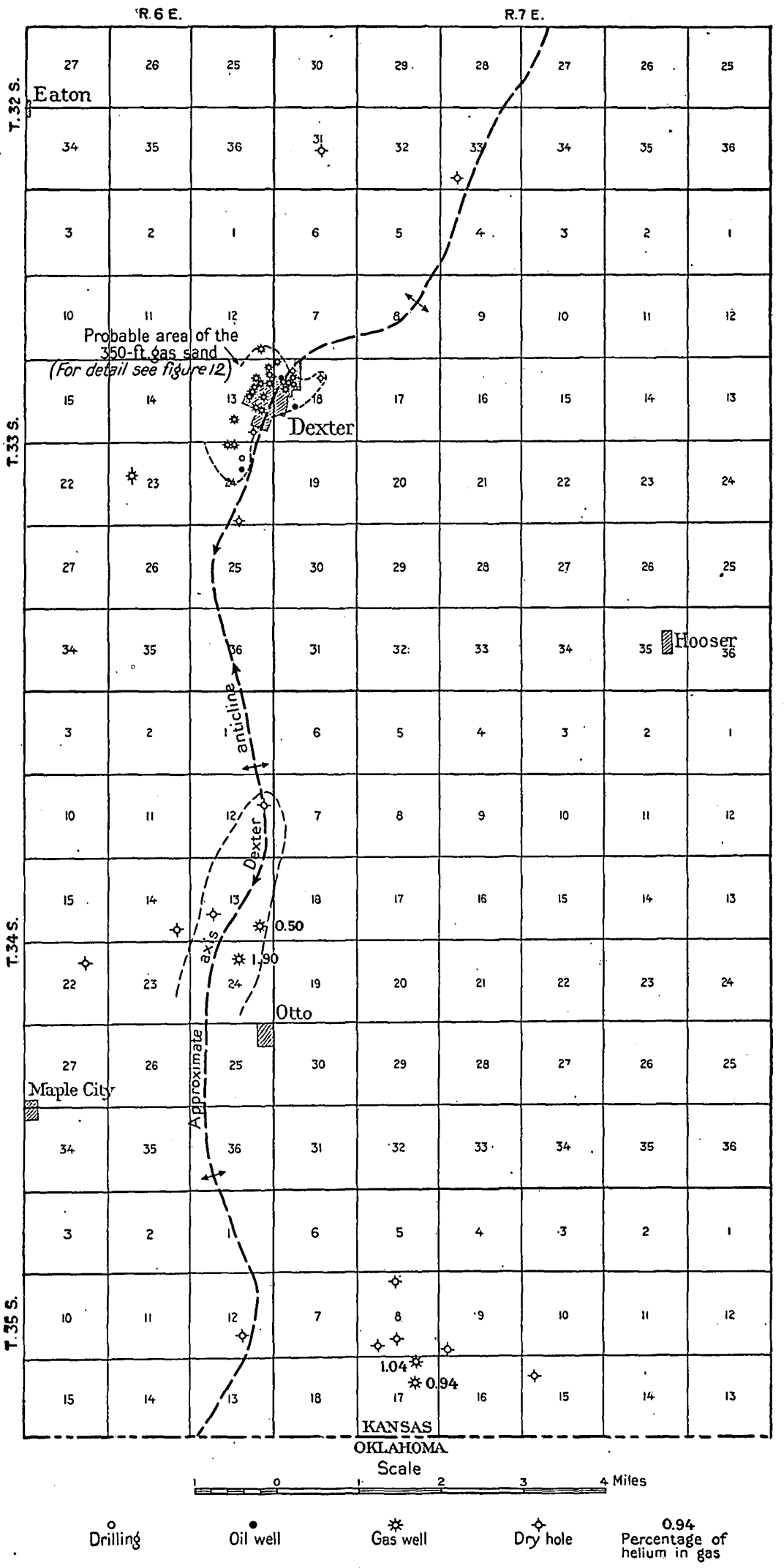
chances of a great exten- Fraure 11.-Sketch map of Dexter-Otto area, Cowley County, Kans., showing location of wells sampled sion are rather slender. 
OLD DEXTER FIELD.

Gas was discovered at Dexter in 1905 at a depth of 325 feet, and during 1906 to 190822 producing wells and 1 dry. hole were drilled. Most of the wells were put down within the town limits, and the field, though very productive, was small. The gas sand ranges between 20 and 55 feet in thickness and is encountered at depths between 300 and 350 feet. The initial rock pressure was unusually high for this depth, being 110 pounds to the square inch, and the maximum open flow was 10 million cubic feet a day, though the average was about 3 million cubic feet. Several deep wells drilled for oil in this area in the last two years have found some gas at the same horizon, one well having found, it is said, enough gas to blow the water out of a 16-inch hole. At present half a dozen of the old wells are still

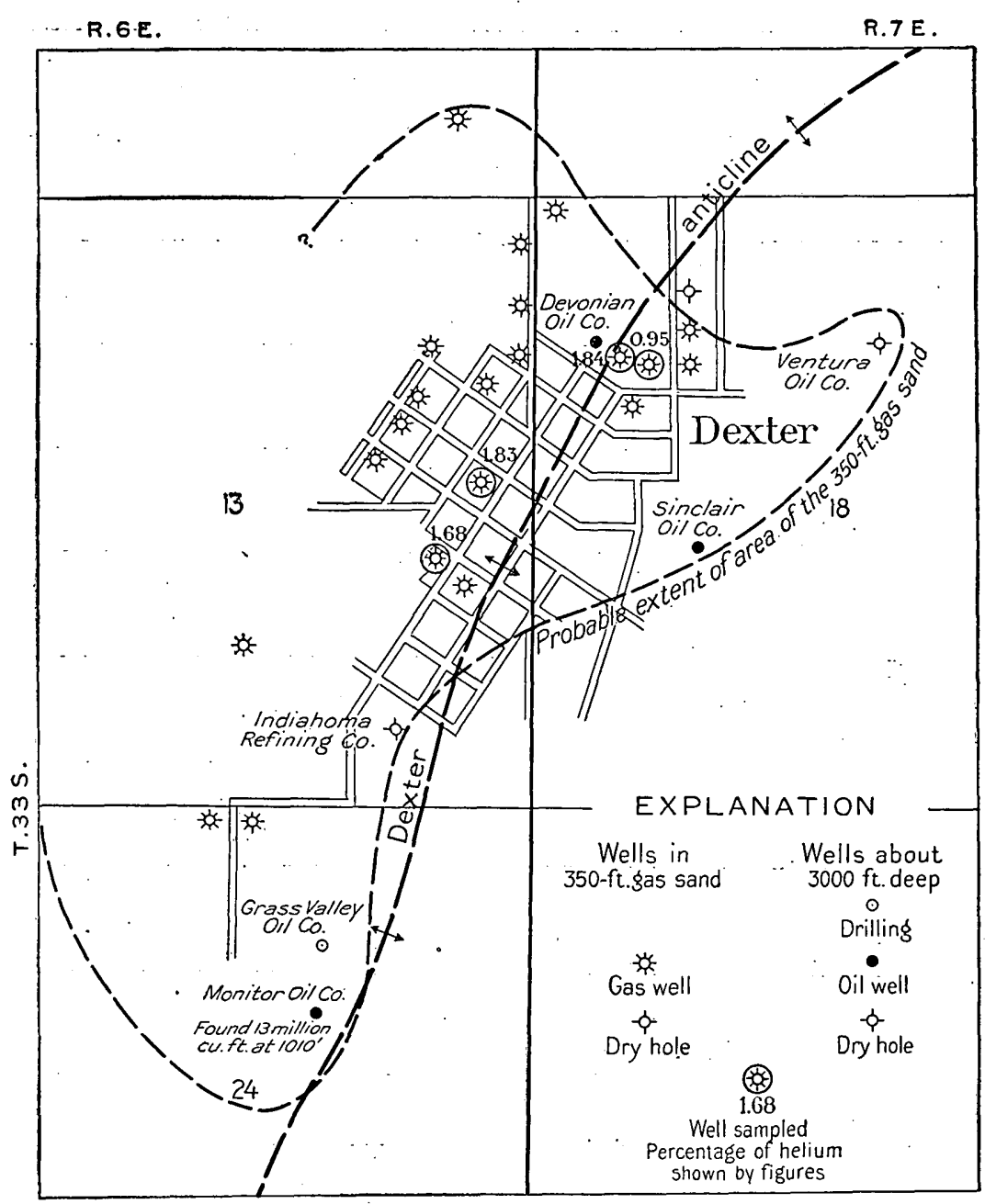

FIGURE 12.-Detailed map of the town of Dexter, Kans., showing location of wells sampled and helium content of gas. producing a few thousand cubic feet a day (See fig. 12.)

The Dexter gas is famous because of its peculiar composition and especially because when examined by Cady and McFarland in 1905 it was the only gas of this type known, its analysis having led to all the subsequent work on helium. Two samples tested by Cady and McFarland in 1905-6 showed 1.64 and 1.84 per cent of helium; two others collected by the writer in August, 1918, showed 1.68 and 1.83 per cent; and one collected by a local operator in the spring of 1918 showed only 0.95 per cent, but this sample possibly contained air.

The Dexter field is regarded as exhausted, and there appears to be no warrant for expecting the discovery of further large supplies. As the largest wells were drilled on the western edge of the pool, however, it is believed that some gas at least can be obtained by drilling in the central or western part of sec. 13. (See fig. 12.) The small cost of the wells and the very high helium content of the gas would compensate in a measure for the small volumes that can probably be obtained.

The only other noteworthy occurrence of gas in the vicinity of Dexter was reported from the Monitor Oil Co.'s well in the NE. $\frac{1}{4}$ sec. 24 . In this well a large volume of gas, variously estimated at $9 \frac{1}{2}$ to $13 \mathrm{mil}-$ lion cubic feet, was encountered at 1,010 feet, and an analysis of this gas is said to haveshown more than 80 per cent of nitrogen. As the wells about two-thirds of a mile north and south of this well found no gas at this horizon, it is evident, however, that the gas-bearing area is very small. 
AREA NEAR OTTO.

As shown in figure 11, several wells have been drilled about 6 miles south of Dexter, where there is a small dome on the crest of the main anticline. The southernmost of these wells found 2 million cubic feet of gas at a depth of 1,141 feet, and the three wells drilled farther north on the axis of the fold all found smaller volumes at about the same horizon. As the wells to the west found the sand filled with water, the productive area can not extend far down the flank of the fold, but it may extend some distance along the axis to the south. Two samples of this gas collected by the writer showed 1.9 and 0.5 per cent of helium. The poorer sample, however, is to be regarded with suspicion, for in the well from which it was taken the pressure was only a few ounces to the square inch, and the sample may have been contaminated with air. Apparently, therefore, this gas is exceptionally rich in helium, and it is believed that a moderate supply might be developed by further drilling toward the south.

AREA SOUTHEAST OF OTTO.

About three years ago two gas wells were drilled by the Standish Oil Co. in sec. 17, T. 35 S., R. 7 E., about 5 miles southeast of Otto. These wells encountered the gas at a depth of about 1,475 feet and had initial open flows of $4 \frac{1}{2}$ and 5 million cubic feet a day, with a rock pressure of about 500 pounds to the square inch. Samples of the gas from these wells showed 0.94 and 1.04 per cent of helium. According to A. E. Fath, who made a geologic examination of the fields for the Geological Survey, there are no structural features in the vicinity favorable to the accumulation of gas and there is little prospect of an extension of the producing area.

SEDAN DISTRICT.

GENERAT FEATURES

Chautauqua County, in which the Sedan district is situated, has for many years ranked high among the oil-producing counties of Kansas, and the eastern and central parts of the county have now been thoroughly prospected. Two fair-sized gas fields, the Hale and Havana fields, have been developed in the eastern part of the county, and a numb.r of small fields in the central part-the Sedan district-yield a moderate volume of gas. The many samples that have been collected and analyzed indicate that the gas in the eastern part of the county contains less than 0.5 per cent of helium but that practically all the gas occurring in the central part at depths shallower than 1,000 feet contains between 0.5 and 2 per cent. (See results of tests, p. 100.) The western part of the county is practically untested, but development is now proceeding toward the west, and it is probable that the helium-rich area will be found to extend a considerable distance in that direction.

The location of the Chautauqua County gas fields is shown on Plate I; and the structure section on that plate shows the approximate stratigraphic position of the samples analyzed. It is evident that the decrease in helium content toward the east is related to the geology, for the helium-rich gas at Sedan occurs in the Kansas City group and owing to the general westward dip of the strata this formation lies too close to the surface to be gas-bearing in the eastern part of the county. In that locality production is obtained from lower beds, which generally yield gas poor in helium. The easternmost field in which gas carrying as much as 0.5 per cent of helium has been found is the Monet field, about 5 miles east of Sedan.

The helium-rich gas of the Sedan district is high in nitrogen and thus too low in heating value to be in demand as a fuel, though owing to local conditions considerable volumes of it have been produced and used. The gas occurs above the oil horizons, however, and unless there happens to be a local demand for gas as fuel it is generally allowed to go to waste; in fact, as it interferes with drilling it is regarded by most operators as a nuisance. Because of these conditions accurate information as to the depth of a shallow gas and as to its volume and pressure is very difficult to obtain.

ROGERS POOL.

The Rogers pool lies just east of Rogers station on the Missouri Pacific Railroad, or chiefly in secs. $23-26,35$, and 36, T. 33 S., R. $10 \mathrm{E}$. (See fig. 13.) It consists of 41 gas wells, of which only 22 are now producing. As shown on the map, the pool is divided into two distinct portions by a strip of barron territory crosising secs. 25 and 26 , in which $10 \mathrm{dry}$ holes have been drilled.

The strata exposed in the vicinity of the Rogers pool belong to the lower part of the 
Shawnee group and the upper part of the can not be determined from surface examinaDouglas group. The Oread limestone, the tions, and drilling may prove the remainder of highest formation of the Douglas, crops out in the uplift to be barren, but the areas that are the southern part of the field. In the southern structurally most favorable have not yet been part of the pool the producing gas is encoun- adequately tested. The favorable areas intered at depths of 700 to 800 feet and lies about 700 feet beneath the Oread, or near the middle of the Kansas City group: In the northern part of the pool, however, the producing sand lies at a slightly higher horizon, being encountered at depths of 650 to 750 feet, and in this district a gas sand at 350 to 450 feet is also eported by many wells. clude the N. $\frac{1}{2}$ sec. 30 , the W. $\frac{1}{2}$ sec. 19 , and all of sec. 24 , and probably also the E. $\frac{1}{2}$ sec. 13 , the W. $\frac{1}{2}$ sec. 18 , and the SW. $\frac{1}{4}$ sec. 23 . Production may also be extended farther west; the gas well in the NE. $\frac{1}{4}$ sec. 34 , for example, which is drilled on a monocline, indicates that there is at least a small pool in that locality. It should be pointed out in this connection

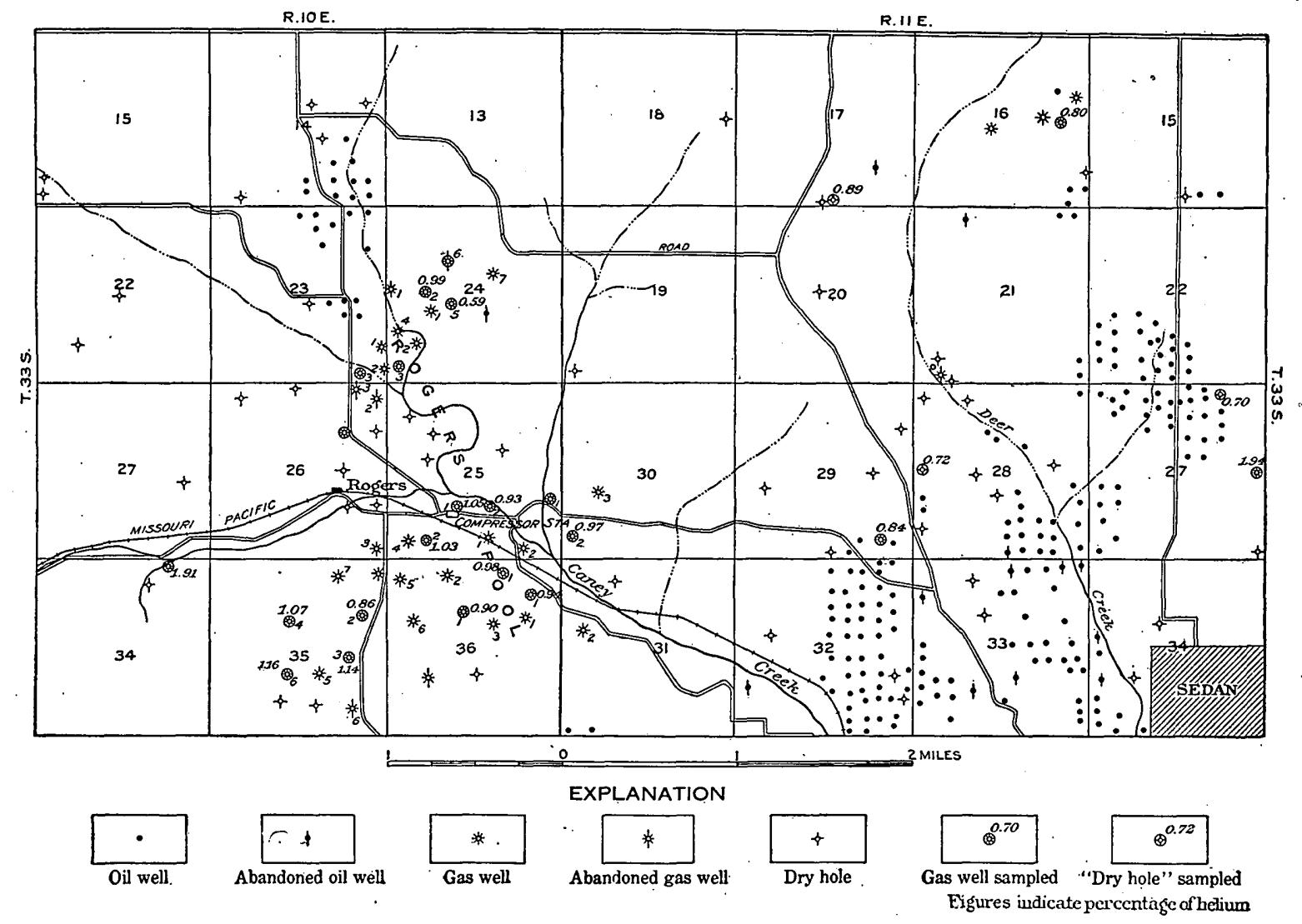

Fugure 13.-Map of Sedan district, Kans. showing location of wells sampled and helium content of gas.

According to P. V. Roundy, who made a detailed geologic examination of the Sedan district, the Rogers pool is associated in a general way with a structurally high area or broad nose which centers in the SE. $\frac{1}{4}$ sec. 19 and extends to the SW. $\frac{1}{4}$ sec. 23 . The limits of the producing area, however, are evidently determined by the porosity and continuity of the sand, for the barren strip that crosses the center of the field lies near the highest part of the uplift. Such conditions of course that too much weight can not be attached to the "dry" holes shown on the map, for these wells were drilled for oil, and moderate flows of low-pressure gas are generally saved only when there is a special need or market for them.

Structural features of the type described above occur throughout a large part of western Chautauqua County, and it is probable that many of them are associated with gas pools and that the gas occurring at depths of 900 
feet or loss for at least several miles west of Rogers is rich in helium.

The first wells in the Rogers pool were drilled in 1912, and by the end of 191318 wells, with a combined open flow of 63 million cubic feet a day and an average rock pressure of 221 pounds to the square inch, had been finished. The initial open flow of some of the wells was as much as 8 million cubic feet a day, though the average was about half that figure. By the summer of 191424 wells, having an average open flow of $2 \frac{1}{2}$ million cubic feet a day, were in operation. During 1914 the field produced only $1 \frac{1}{2}$ to $2 \frac{1}{2}$ million cubic feet daily, chiefly owing to the poor quality of the gas for heating. During the winter of 1915-16 the field was taken over by another gas company and was made to produce as much as 10 million cubic feet a day. Since that time the production has gradually declined until in August, 1918, it amounted to only about 1 million cubic feet daily. At that time the average daily open flow of the 22 producing wells was 260,000 cubic feet, their average rock pressure was 38 pounds to the square inch, and their combined daily open flow was a little less than 6 million cubic feet.

Although the foregoing figures indicate that the pool is now almost exhausted, it is believed that this condition is due partly to the fact that the gas commands so low a price that the well owners have not felt justified in going to much expense in keeping the wells in proper condition. The oil wells of Chautauqua County, though generally small; are remarkable for their long life, a feature evidently due to the fine grain of the oil sand and to the rather low gas pressure. Whether or not the gas sands in this area are also capable of unusually long continued production it will be impossible to say, for practically all the gas wells visited by the writer in the Sedan district had suffered from lack of attention. Despite this condition, however, many old wells have held up remarkably well, and there is reason to believe that the fields of the Sedan district would, with proper care, yield a moderate output for a long period.

It should not be inferred from the foregoing remarks that the Rogers pool itself can still be rejuvenated, though undoubtedly the production could temporarily be somewhat increased. So far as can be learned from a study of the structure, however, there is still good territory in the vicinity, and it is probable that the producing area could be somewhat extended. Moreover, there is every reason to. suppose that similar pools could be developed in the central and western parts of the county and that their gas would prove equally rich in helium.

Two pipe-line samples of gas from the Rogers pool average 0.96 per cent of helium, and 14 samples from individual wells contained from 0.86 to 1.16 per cent. One sample showed only 0.59 per cent, but it may have been contaminated by air, and on the other hand gas from the well in the NE. $\frac{1}{4}$ sec. 34 (see fig. 13) showed 1.912 per cent. All these gases are from the sands between 650 and about 800 feet in depth, and the gas occurring at 350 to 450 feet in the northern part of the Rogers pool probably contains well over 1 per cent of helium.

The general character of the gas of the Rogers pool is shown by analysis 20, page 39 .

AREA NEAR SEDAN.

Although practically no gas is now produced in the areas north of Sedan and between Sedan and the Rogers pool, it is stated on good authority that many of the oil. wells in these areas encountered gas at shallow depths. A few samples of this gas, obtained mostly from abandoned and practically exhausted wells, showed a high content of helium. In the district south of Sedan a little gas is now being produced, but all of it is derived from the Peru sand, which lies about 500 feet beneath the helium-bearing sands of the Rogers pool and which yields gas carrying only about 0.4 per cent of helium. . It is reported, however, that wells in several localities encountered gas at shallower depths, and it may be presumed that this gas contains more than 0.5 per cent of helium.

The richest gas occurs in a sand found at a depth of about 400 feet in the area north of Sedan. Several wells were finished in this sand some years ago to supply fuel for. drilling oil wells, but because of the low pressure of the gas and its low heating value no care was taken of the gas wells, and most of them soon became exhausted. Howevèr, the Fleming \& Wadsworth well, near the east quarter corner of sec. 27 , which was drilled about 1907 , is said 
to have had an initial daily open flow of 3 or 4 million cubic feet, and when visited by the writer in July, 1918, it still showed about half a million cubic feet, with a pressure of about 50 pounds to the square inch. The test of a sample of this gas showed 1.94 per cent of helium, and an analysis previously made by Prof. Allen showed 55.7 per cent of nitrogen. (See analysis 18, p. 39.) About a mile east of this well, in the southeast corner of sec. 26 and the southwest corner of sec. 25, T. 33 S.; R. 11 $\mathrm{E}$., three gas wells were drilled to the 400 -foot sand about three years ago, but all of them are now practically exhausted: A sample from the well in the southeast corner of sec. 26 showed 1.04 per cent of helium. A dry hole in the NE. $\frac{1}{4}$ sec. 29 is reported to have passed a sand capable of yielding 2 or 3 million cubic feet of gas daily at a depth of about 400 feet, and several wells could doubtless be drilled in this locality. Two oil wells drilled several years ago just outside the limits of Sedan, near the center of sec. 3 , are reported to have found a sand yielding 3 or 4 million cubic feet of gas a day at a depth of 212 feet. This sand is probably equivalent to the 400 -feet sand north of Sedan, and there is every reason to suppose that the gas is very rich in helium.

It is not to be inferred from the foregoing statements that all the area for 2 or 3 miles north of Sedan is thought to be underlain by the shallow gas. It is even impossible to state that all the wells referred to draw from the same horizon, though this is highly probable; but it is very evident that the sand is either discontinuous or is productive only locally. It is impossible to predict in advance of drilling. how much of this gas could be obtained, but it seems highly probable that a yield of at least 1 or 2 million cubic feet a day could be maintained for a period of two or three years.

A deeper sand, probably equivalent to that found in the Rogers pool, is also encountered in the area north and west of Sedan at a depth of 600 to 700 feet, and in some localities gas is found also in sands at 900 and 1,000 feet. The relation of the sands in this area is shown by the following well log:
Log of Allen McIntosh well No. 1, in the southeast corner of the $S W . \frac{1}{4}$ NE. $\frac{1}{4} \sec .16, T .39 S .$, R. $11 \mathrm{E}$.

\begin{tabular}{|c|c|}
\hline Soil................. & $\begin{array}{r}\text { Feet. } \\
0-3\end{array}$ \\
\hline Shale, black............. & $3-63$ \\
\hline Lime, Oread................ & $63-83$ \\
\hline Shale, red................... & $83-140$ \\
\hline Sand; three bailers of water.... & $140-150$ \\
\hline Shale, black................ & $150-160$ \\
\hline Sand; hole full of water........ & $160-280$ \\
\hline Shale, black................ & $280-410$ \\
\hline Sand $\ldots \ldots \ldots \ldots \ldots \ldots$ & $410-430$ \\
\hline Shale, black............ & $430-455$ \\
\hline Sand $\ldots \ldots \ldots \ldots \ldots \ldots$ & $455-465$ \\
\hline Shale, black............... & $465-708$ \\
\hline Sand, hard; gas........... & $708-712$ \\
\hline Sand, soft................ & $712-720$ \\
\hline Shale, black................ & $720-765$ \\
\hline Lime, white.............. & $765-768$ \\
\hline Shale, black.............. & $768-908$ \\
\hline Sand; gas............... & $908-920$ \\
\hline Shale, white............. & $920-945$ \\
\hline Sand $\ldots \ldots \ldots \ldots \ldots \ldots$ & $945-955$ \\
\hline Shale.......... & $955-960$ \\
\hline Lime................. & $960-962$ \\
\hline Shale, black.............. & $962-972$ \\
\hline Sand; "Salt sand"........ & $972-1,072$ \\
\hline Shale, black............... & $1,072-1,077$ \\
\hline Shale.................... & $1,077-1,130$ \\
\hline Lime................. & $1,130-1,140$ \\
\hline Sand; "Stray sand".... & $1,140-1,162$ \\
\hline Shale, black............ & $1,162-1,172$ \\
\hline Lime................. & $1,172-1,177$ \\
\hline Shale, black............... & $1,177-1,283$ \\
\hline Sand, hard; "Peru sand".. & $1,283-1,289$ \\
\hline Shale, black............... & \\
\hline
\end{tabular}

Five samples of gas from the sands encountered at depths of 700 to 900 feet were collected in the area north and west of Sedan, and their helium content was found to range between 0.70 and 0.89 per cent. The wells sampled are in secs. 16, 17, 27, 28, and 29, T. 33 S., R. 11 E., and their location is shown on figure 13. The well in sec. 29. still has an open flow of about half a million cubic feet a day, but the other wells are practically exhausted. The gas has been reported in many oil wells, however, and there is no doubt that a moderate production could be developed. As already stated, all this gas is too low in heating value and too irregular in distribution to permit producing it at a profit for use as fuel, but as a source of helium its value should be sufficient to warrant the necessary expense. 
MONETT FIELD.

In the vicinity of Monett (see Pl. I) gas has been produced for many years, chiefly from the Salt sand but in part from deeper sands. The Salt sand in this district is found at a depth of 500 to 600 feet. Some of the wells had an initial daily open flow of 3 million cubic feet, though all of them are now very small. The town of Sedan is supplied by half a dozen wells in secs. 28,32 , and 33 , T. 33 S., R. 12 E.; the combined daily production of which is now less than a million cubic feet. 'A sample of the Salt sand gas showed 0.57 per cent of helium.

This gas has not been systematically developed, being undesirable because of its rather low pressure and its low heating value; and it is believed that if necessary a production of 2 or 3 million cubic feet a day could be developed and could be maintained for two or three years. Though the helium content of this gas is lower than that of the gas to the north and west of Sedan, it is higher than that of the other gases within a radius of 35 miles. The Monett gas could be rather cheaply produced, and if an extraction plant were erected in the Sedan district it might prove desirable to treat the Monett gas in connection with the richer product of the Rogers and Sedan fields.

FIELDS IN OSAGE COUNTY, OKLA.

PEARSON FIELD.

The Pearson field is in the central part of Osage County, Okla., principally in secs. 10 to 20, T. 27 N., R. 8 E., on the Midland Valley Railroad. In July, 1918, the Pearson field contained 17 producing wells having an average rock pressure of about 125 pounds to the square inch and a total open flow of about 40 million cubic feet a day. The production of the field during May amounted to 146 million cubic feet, or an average of 4.7 million cubic feet daily, though it is believed that with some additional drilling 10 or 15 million cubic feet a day could easily be produced.

Most of the gas produced in the Pearson field is obtained from sands lying at depths between 750 and 1,000 feet, although several wells recently drilled derive their gas from a sand at about 1,450 feet. The main producing sand lies 100 to 400 feet below the Oread limestone, of the Douglas group and therefore near the base of the Douglas or the top of the $10135^{\circ}-20-6$
Lansing group. According to A. E. Fath, it is roughly equivalent to the sand in the Otto district, Kans., which yields gas carrying about 1 per cent of helium. The structural geology of the Pearson district and of the area to the north has been investigated by K. C. Heald, ${ }^{42}$ who finds that the field is on a well-defined though irregular anticline, the highest point of which appears to be in the southeast corner of sec. 30 , T. 27 N., R. 8 E. In this vicinity there are also several minor domes, at least one of which has proved productive.

As shown by the 12 analyses on page 104, the Pearson gas ranges in helium content between 0.23 and 0.71 per cent, the average as determined by three tests of pipe-line gas being about 0.50 per cent. The gas occurring in the uppermost sands appears to be somewhat richer in helium than that in the lower part of the producing zone.

The general quality of the Pearson gas is shown by the first analysis in the table on page 82.

MYERS FIELD.

The Myers field is about 6 miles southeast of the Pearson field, in the northeast corner of T. 26 N., R. 8 E. In July, 1918, the field contained 10 wells having an average rock pressure of 'about 240 pounds to the square inch and a total open flow of about 15 million cubic feet a day. During May the average daily production was $1,392,000$ cubic feet, or only about 9 per cent of the open flow.

The Myers gas is derived from two sands, the shallower lying at a depth of about 550 feet and the deeper at a depth of about 1,150 feet. These sands are believed to be equivalent to those that are productive in the Pearson field. Although flows as high as 5 million cubic feet a day are found in the shallower sand, the pressure is low, and in July, 1918, all but two of the wells had been deepened to the 1,150 -foot sand.

The field is on a small dome or anticline similar to that from which the gas at Pearson is produced. The wells already drilled apparently define this dome, but there are other structural features of the same type in the vicinity which when developed will doubtless furnish a large volume of gas.

42 Geologic structure of the northwestern part of the Pawhuska quadrangle, Okla.: U. S. Geol. Survey Bul .691, pp. 82, 89, 1918. 
A pipe-line sample of the Myers gas was found to contain 0.37 per cent of helium, and three samples from individual wells carried $0.27,0.35$, and 0.43 per cent. (See p. 104.) The helium content of the Myers gas is thus distinctly lower than that of the gas of the Pearson field, though the gas is believed to occur at about the same horizon. As shown by the third analysis in the following table, the Myers gas is considerably lower in nitrogen than the Pearson gas:

Analyses of gas from the Pearson and Myers fields, Oklahoma.

\begin{tabular}{|c|c|c|c|}
\hline & \multirow{2}{*}{$\begin{array}{c}\text { Pearson } \\
\text { feld, gas } \\
\text { at } 900 \text { feet. }\end{array}$} & \multicolumn{2}{|c|}{ Myers field. } \\
\hline & & $\begin{array}{l}\text { Gas at } 317 \\
\text { feet. }\end{array}$ & $\begin{array}{l}\text { Gas at } 1,150 \\
\text { feet. }\end{array}$ \\
\hline $\begin{array}{l}\text { Carbon dioxide }\left(\mathrm{CO}_{2}\right) \ldots \ldots \\
\text { Oxygen }\left(\mathrm{O}_{2}\right) \ldots \ldots \ldots \\
\text { Methane }\left(\mathrm{CH}_{4}\right) \ldots \ldots \ldots \ldots \\
\text { Ethane }\left(\mathrm{C}_{2} \mathrm{H}_{6}\right) \ldots \ldots \ldots \ldots \\
\text { Residue }\left(\mathrm{N}_{2}, \text { etc. }\right) \ldots \ldots\end{array}$ & $\begin{array}{r}0.00 \\
.21 \\
51 . .91 \\
1.12 \\
46.86\end{array}$ & $\begin{array}{r}0.25 \\
.12 \\
76.60 \\
2.25 \\
20.78\end{array}$ & $\begin{array}{r}0.86 \\
.00 \\
58.60 \\
5.69 \\
34.85\end{array}$ \\
\hline $\begin{array}{c}\text { Heating value } \text { (British } \\
\text { thermal units)............. }\end{array}$ & $\begin{array}{r}100.00 \\
520\end{array}$ & $\begin{array}{r}100.00 \\
778\end{array}$ & $\begin{array}{r}100.00 \\
664\end{array}$ \\
\hline
\end{tabular}

In sec. 23 , T. 26 N., R. 9 E., about 5 miles southeast of the Myers field proper, large volumes of shallow gas are reported. A deep well in that locality is said to have encountered a sand yielding 6 million cubic feet a day at a depth of 317 feet, one yielding 3 million cubic feet at a depth of 410 feet, and one yielding 2 million cubic feet at a depth of 660 feet. This gas was not tested for helium, but, as shown by the second analysis in the above table, the gas at 317 feet carries 20.78 per cent of nitrogen and is probably at least as rich in helium as the gas in the main Myers field.

PROSPECTIVE FIELDS IN WESTERN OSAGE COUNTY.

The eastern part of Osage County comprises some of the richest oil and gas territory in the Mid-Continent region, but that portion lying west of the Pearson and Myers fields is practically undeveloped. This condition is due chiefly to the fact that the lands throughout the county are the common property of the Osage Tribe, and the leasing of the lands for oil and gas development has therefore been strictly controlled by the Government. During the last year or two, however, a great many leases in the western Osage country have been sold, and within a short time a number of pools will doubtless be discovered.
Production in the eastern part of Osage County and in Washington, Nowata, and Rogers counties, still farther east, is obtained from sands beneath the "Oswego lime," or chiefly in the Cherokee shale. As shown by many analyses, the Cherokee gas is characterized by rather low nitrogen content, and therefore only a few samples of it were tested for helium. None of these samples contained more than 0.1 per cent. The location of the principal gas fields in this region and data as to the helium or nitrogen content of the gas are shown on Plate I.

Because of the prevailing westerly dip the Cherokee sands lie at considerable depths in the western part of Osage County, but higher sands which are productive elsewhere in northern Oklahoma and southern Kansas lie at moderate depths. The geology of the western Osage country has been examined in detail by members of the Geological Survey, ${ }^{43}$ and a great many small folds of the type that has proved so productive farther east have been found. There is therefore no reason to doubt that the western Osage country will yield large volumes of gas and that a number of fields similar to those at Pearson and Myers will be developed in this region.

From all the information at hand it appears that at least the northwestern part of Osage County should be productive of gas fairly rich in helium. The gas-bearing zones which occur at shallow depths in the western part of Osage County are equivalent to those which contain helium-rich gas in Chautauqua County and the eastern part of Cowley County, Kans. The district near Otto, Kans., for example, in which the gas contains 1 per cent of helium, lies only about 2 miles from the northern edge of Osage County and directly along the strike of the rocks. Moreover, the fact that the Myers field produces gas averaging about 0.4 per cent of helium and the Pearson field, about 6 miles to the west, produces gas averaging at least 0.5 per cent, suggests a progressive increase in helium content toward the west. It is therefore believed that gas containing at least 0.75 per cent of helium will be encountered in the northwestern part of Osage County at fairly shallow depths and that in all probability large volumes of such gas will be available. So far

43 White, David, and others, Structure and oil and gas resources of the Osage Reservation, Okla.: U. S. Geol. Survey Bull. 686 (in press). 
ns can be judged this aren comprises the best prospective helium territory in the United States.

\section{OTHER MID-CONTINENT FIELDS.}

In addition to the fields already described, which are noteworthy as present or prospective sources of gas fairly rich in helium, there are many districts in the Mid-Continent region that yield small volumes of helium-rich gas or large volumes of gas containing only about 0.25 per cent of helium. The location and helium content of these supplies are shown on Plate I, and data regarding the volume of the gas, the depth from which it is obtained, etc., are given in the tables at the end of this report.

MINOR FIELDS IN KANSAS.

Cady and McFarland in 1906 found a number of gases that contained more than 0.25 per cent of helium; in fact, as shown on Plate I, all the Kansas gases examined appear to contain measurable proportions of helium, and the average content of all the gas that has been produced in the State is probably more than 0.15 per cent. Many of the fields investigated by Cady and McFarland are now, however, practically exhausted, for the gas resources of Kansas have been heavily drawn upon in the last 15 years, and since 1908 there has been a great decline in production. (See fig. 14.) A

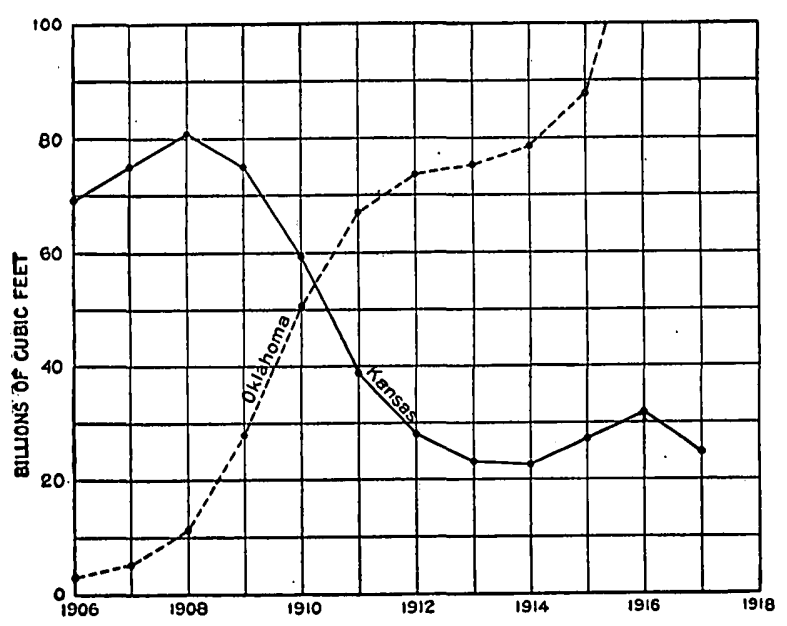

Fravae 14.-Diagram showing production of natural gas in Kansas and Oklahoma.

temporary increase was recorded in 1915-16, owing chiefly to the discovery of the Eldorado and Augusta fields, but production fell off again in 1917-18, and there seems to be small prospect of any notable increase in the future.
One of the richest gases reported by Cady and McFarland was that from Eureka, in Greenwood County, two samples of which were found to carry 1.50 per cent of helium. The Eureka field was investigated in 1918 and was found to be practically exhausted, though a sample was collected and found to contain $\mathbf{1 . 4 2}$ per cent of helium. The Moline and New Albany fields in Elk County, and the Burlington field, in Coffey County, all of which produce gas carrying about 0.5 per cent of helium, and the Fredonia field, in Wilson County, which yields gas carrying about 0.6 per cent, furnished considerable volumes of gas in 1906 but now produce only an insignificant supply. The same is true of the Buffalo, Altoona, and Neodesha fields, in Wilson County, and the Chanute field, in Neosho County, all of which produce gas carrying about 0.3. per cent of helium; and of the Spring Hill field, in Johnson County, and the Garnett field, in Anderson County, which yield gas carrying about 0.4 per cent.

A number of fields have of course been discovered in Kansas since Cady and McFarland made their survey, but all of them except the Eldorado, Augusta, Otto, and Sedan fields are either small or yield gas rather poor in helium. The Beaumont field, in the southwestern part of Greenwood County, is perhaps the most promising, for it yields gas containing 0.86 per cent of helium. Although in July, 1918, there was only one gas well in this field, considerable volumes of gas were reported in all the surrounding oil wells, and it is probable that a production of several million cubic feet a day could be developed. A small supply of gas carrying 0.65 per cent of helium has also been recently found near Virgil, and a larger supply containing 0.36 per cent near Toronto, Greenwood County. Near Winfield, Cowley County, there is an old field which is still capable of producing almost a million cubic feet a day of gas carrying 0.38 per cent of helium.

In Elk and Chautauqua counties several fields have recently been discovered that yield gas carrying more than 0.33 per cent of helium. Near Longton and Oak Valley, in the southeast corner of Elk County, there are two small pools of shallow gas containing 0.55 and 0.40 per cent of helium. In September, 1918, each of these pools was producing about 1 
million cubic feet a day, and the supply could doubtless be increased by further drilling. $\cdot \mathrm{A}$ large volume of deep gas was also discovered in 1918 near Oak Valley, but it contains only 0.001 per cent of helium. The gas of the Hale and Havana fields, in the eastern part of Chautauqua County, averages about 0.36 per cent of helium, and in September, 1918, these fields were together producing about 10 million cubic feet a day. This supply can doubtless be increased. Most of the gas produced in the Chautauqua field, in the southern part of the county, is derived from deep sands and contains very little helium, but a small supply of gas is also obtained at a depth of 600 to 800 feet, and this carries 0.21 to 0.43 per cent.

MINOR FIELDS IN OKLAHOMA.

As shown in figure 14, Oklahoma produces a very large quantity of gas annually, and since 1906 the production has steadily increased. In 1917 Oklahoma furnished about 137 billion cubic feet and became the second largest gasproducing State in the Union. As shown on Plate I, however, the Oklahoma area of gas containing more than 0.5 per cent of helium is practically confined to the northwestern part of Osage County, whereas a very large proportion of the gas produced in Oklahoma is obtained from fields east of that area and from those in the southern part of the State. The average helium content of Oklahoma gas is therefore exceedingly small, and only a few fields outside of the western part of Osage County deserve special mention.

As pointed out on page 40 , the shallow gas produced in the western part of the northern Oklahoma petroleum region is characteristically rich in nitrogen but poor in helium. For example, in the Pearson gas the ratio of nitrogen to helium is probably almost 100 , and it attains a similar value in several other Oklahoma gases, whereas in the rich Kansas gas the ratio is usually less than 50. In other words, a Kansas gas containing 50 per cent of nitrogen is likely to carry about 1 per cent of helium, whereas an Oklahoma gas carrying the same proportion of nitrogen may contain only 0.5 per cent of helium. High-nitrogen gases have been found at many localities in the western parts of Osage and Pawnee counties and in Payne, Noble, and Kay counties, Okla., but it must be borne in mind that a high-nitrogen gas in this district is not necessarily a gas rich in helium.
The Pearson and Myers fields, in Osage County, have already been described, and the prospective importance of the western Osage country as a source of helium-bearing gas has been pointed out. The only other field yet developed in the Osage region that may be of value as a source of helium is the Hominy field, which lies about 25 miles south of Pearson. This is primarily an oil field, but most of the wells report large volumes of gas at depths of about 500 feet. This gas has been cased off, but a few wells have been finished in a gas sand at about 1,000 feet. Three analyses of Hominy gas, probably that from the 1,000 -foot horizon, show 15 to 20 per cent of nitrogen, and it is probable that the 500-foot gas is still higher in nitrogen and may therefore contain enough helium to be of commercial value.

The Blackwell field, in the northern part of Kay County, is one of the largest gas fields in Oklahoma. Its productivity is due chiefly to the large number of gas-bearing sands present; one well, for example, encountered eight gas sands between 692 and 3,200 feet, the combined open flow of which was 116 million cubic feet daily. ${ }^{44}$ Because of the large volumes of gas available in the Blackwell field and the fact that some of it occurs at shallow depths, six samples of the gas from different sands were tested for helium, but the highest content found was only 0.27 per cent.

The Ponca City field, in the southern part of Kay County, produces a considerable quantity of oil and formerly yielded large volumes of gas, but the gas resources are now almost exhausted. The gas occurs chiefly at a depth of about 500 feet, and the sand is regarded as about equivalent to the 950 -foot sand at Blackwell and more than 1,000 feet stratigraphically higher than the producing sands of the Pearson and Myers fields. An analysis of the gas by Prof. Allen showed 40.1 per cent of nitrogen, but the helium content of gas from the same well proved to be only 0.36 per cent.

The Billings field, in the northern part of Noble County, is chiefly an oil field, though large volumes of gas are encountered at depths of 400 to 1,100 feet, and a little of this gas is produced to supply the local demand. A sample of gas occurring in Permian strata at a depth of 500 feet contained, however, only 0.10 per cent of helium, and a sample from a

$\$ 4$ Petroleum and natural gas in Oklahoma: Oklahoma Geol. Survey. Bull. 19, p. 272, 1917. 
sand at 1,036 feet was found to carry 0.39 per cent. As shown by analysis 21, on page 39, this gas contains 42.5 per cent of nitrogen.

The Morrison field, in the western part of Pawnee County, has produced large volumes of gas, though the output is now declining. The gas occurs at a depth of about 2,000 feet and carries 22 to 25 per cent of nitrogen but only about 0.24 per cent of helium.

The Ingalls field, about 10 miles east of Stillwater, Payne County, contains only half $\mid$ p. 27.)
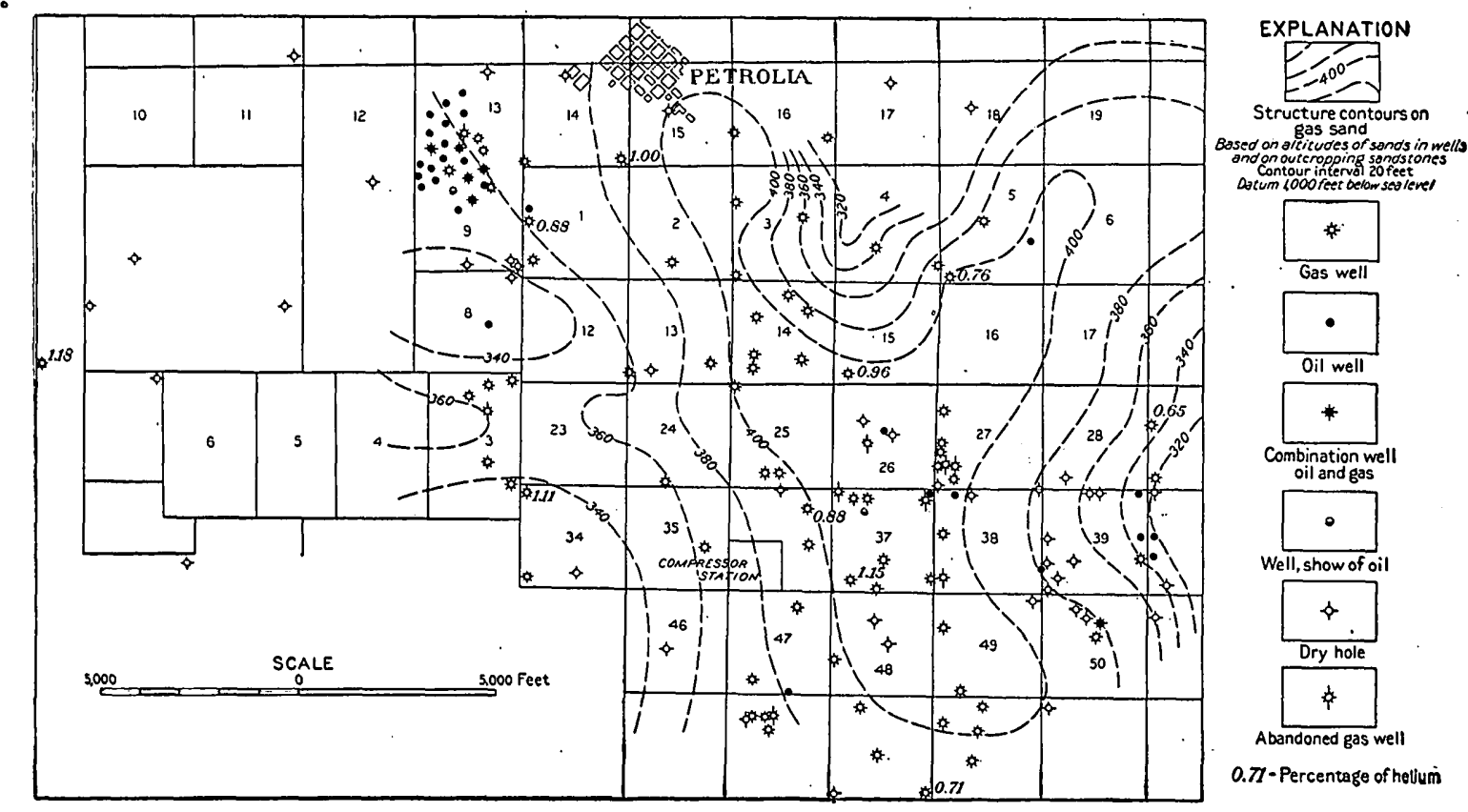

FIaURE 15.-Map of Petrolia field, Tex., showing location of wells sampled and helium content of the gas.

a dozen oil and gas wells and is of interest chiefly because of the high nitrogen content of the gas and because of the large flows reported. In the first gas well a flow estimated at 21 million cubic feet of gas a day was found at 650 feet, another of 57 million cubic feet at 1,760 feet, and one of 30 million cubic feet at about 3,200 feet. The shallow gas was cased off, but the gas at 1,760 feet was produced for about a year. Analyses of this gas showed from 50 to 54 per cent of nitrogen, and a sample which is thought to represent the same gas contained 0.35 per cent of helium. A sample from a deeper sand carried only 0.05 per cent of helium. It was not possible to obtain a sample of the 650 -foot gas, which is doubtless richer in helium than that at 1,760 feet, but it is believed that no great supply of either of these gases can be developed.
A small supply of gas said to contain 30 per cent of nitrogen has been found about 7 miles south of Bristow, Creek County, but this gas proved to contain only 0.15 per cent of helium.

Large volumes of gas are now produced in southern Oklahoma, and further supplies will doubtless be discovered in that region. All the existing sources in southern Oklahoma have been sampled, however, and have proved to be very poor in helium. (See Pl. III and 
Petrolia field, but about 250 of them are oil wells, averaging only 300 feet in depth. The gas-bearing beds lie at a depth of 1,550 to 1,750 feet and in places carry some oil. Of the wells drilled to this horizon about 65 found gas in commercial quantities, and about 35 found oil. The limits of the field are now pretty well defined by dry holes.

GEOLOGIC OUTLINE.

The surface rocks in the Petrolia field belong to the Wichita formation, of Permian age. These beds extend to a depth of 1,000 feet or so, and the deep oil and gas probably occur in the Cisco formation, of upper Pennsylvanian age.

As shown in figure 15, the field is on the crest of an irregular anticline, the long axis of which within the field trends about northnorthwest. According to Shaw, ${ }^{45}$ there is probably, however, a branch anticline or nose extending to the northeast, and a similar nose extending to the northwest. The best production has in general been obtained from the highest part of the main anticline, although there are many local irregularities caused by variations in the porosity of the sand.

Commercial supplies of gas are apparently confined to a group of beds which in the center of the field lie at depths of 1,500 to 1,750 feet. A study of the well logs indicates that there are two fairly persistent sands, or groups of sands-one lying at a depth of about 1,550 feet and the other at about 1,700 feet. A gas zone intermediate between these two is also reported in most wells, and there are in addition a number of "stray" sand lenses. All the individual sands are discontinuous and irregular, however, and can be traced only for short distances. In most of the wells the sands at the three main horizons are all more or less productive, but a few wells have found gas only in the lower group of sands. On the other hand, some of the wells, especially the earlier ones, stopped in the upper or middle sands, and the lower ones have not been tested.

The general character of the gas-bearing beds is shown in the following partial logs:

${ }^{45}$ Shaw, E. W., Matson, G. C., and Wegemann, C. H., Natural-gas resources of parts of north Texas: U. S. Geol. Survey Bull. 629, pp. 25-41, 1916.

Typical logs of wells in the Petrolia field, Tex.

Stine Öil \& Gas Co., Stine well 1.

Feet.

Water sand ... 1, 322-1,348

Blue shale ... 1, 348-1,365

Red rock..... ], 365-1, 372

Blue shale.... 1, $372-1,470$

White slate... 1, 470-1,551

Sand (dry, but

probably

represents

upper gas

sand in

other wells). 1,551-1,555

Shale........ 1, 555-1,682

Sandy shale. . 1,682-1, 694

Gas sand...... 1, 694-1, 708

Blue shale.... 1, 708-1, 719

Gas sand ( 16

million $\mathrm{cu}-$

bic feet) . . . 1, 719-1, 731

Blue shale... 1,731-1,739

Broken sand.. 1,739-1,744

Blue shale... 1,744-1,750

Sand shale... 1., 750-1, 752

Red shale..... 1,752-1, 755

Blue shale.... 1, 755-1, 757

Broken sand.. 1,757-1,763

Blue shale.... 1, 763-1, 783

QUALITY OF THE GAS.

Since the Government began operations in the Petrolia field the helium content of the gas has been repeatedly determined and appears to average about 0.93 per cent. The proportion of helium is not constant from week to week, however, but varies by as much as 0.1 per cent. This is shown by the following tests made by different chemists over a period of six months:

Tests of the helium content of Petrolia gas.

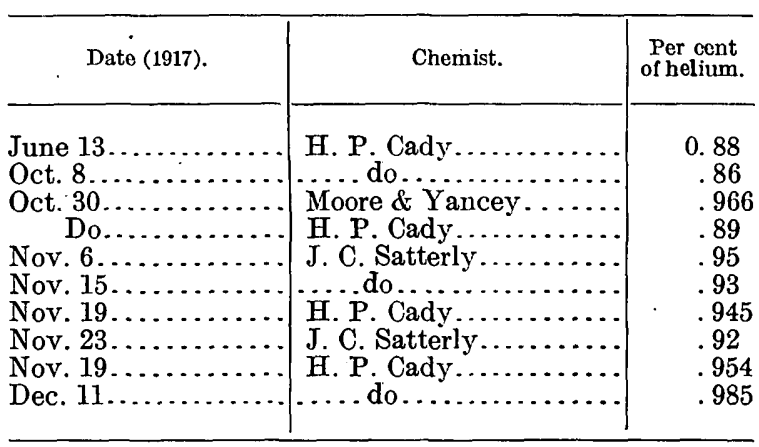

These tests show an apparent increase in helium content from month to month, but whether this is a regular increase that is likely to continue or simply a fortuitous variation 
due to analytical error or to unexplained natural causes is not clear.

The tests of 10 samples of gas from individual wells given on page 86 show a range in helium content between 0.65 and 1.18 per cent, and the gas in the uppermost group of sands seems to be somewhat richer than that in the others. There is, however, no marked and constant difference in. helium content between gases from different parts of the producing zone, and there appears to be no possibility of segregating the richest gas.

The general quality of the Petrolia gas is shown by the following analyses:

Analyses of gas from the Petrolia field.

\begin{tabular}{|c|c|c|c|c|}
\hline & 1 & 2 & 3 & 4 \\
\hline 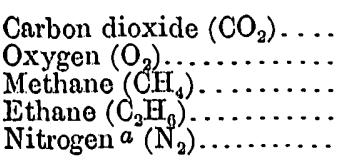 & $\begin{array}{r}0.2 \\
.0 \\
48.4 \\
12.8 \\
38.6\end{array}$ & $\begin{array}{r}0.2 \\
.0 \\
52.7 \\
9.3 \\
37.8\end{array}$ & $\begin{array}{r}0.0 \\
.0 \\
51.1 \\
10.0 \\
38.9\end{array}$ & $\begin{array}{r}0.0 \\
.0 \\
51.5 \\
10.2 \\
38.3\end{array}$ \\
\hline $\begin{array}{l}\text { Heating value (British } \\
\text { thermal units per cubic } \\
\text { foot at } 0^{\circ} \mathrm{C} \text {. and } 760 \\
\text { millimeters pressure)... }\end{array}$ & 100.0 & 100.0 & 100.0 & 100.0 \\
\hline Specific gravity.......... & 0.78 & 0.76 & 0.76 & 0.76 \\
\hline
\end{tabular}

a Includes helium.

1,2. Citod from U. S. Geol. Survoy Bull. 629, p. 41, 1916. 1. Gas from Matlock woll 1, which supplies Petrolia; anaiysis by G. A. Burrell,
Bureau of Mines. 2. Gas rom Beatty well 1; analysis furnished by

Lone Star Gas Co.
3.4. Pipe-lino samples of Petrolia gas, collected in September and October, 1914 at Fort Worth Tex, and analyzed by the Bureau of Mines. 'Cited from Bureau of Mines Tech. Paper 109, p. 7, 1915.

PRODUCTION OF THE FIELD.

The first gas well in the Petrolia field was drilled in October, 1907, and was reported to have had a 4-minute pressure of 470 pounds to the square inch and a capacity of 8 to 10 million cubic feet a day. Most of the other early wells, however, had initial pressures of 600 to 740 pounds and open flows of 10 to 40 million cubic feet. Most of the recent wells have come in with pressures of 200 to 300 pounds and flows of 2 to 15 million cubic feet. The average pressure of all wells in the field on June 1, 1918, was 82 pounds, and the average open flow on January 1, 1918, was $1,686,000$ cubic feet.

About 65 successful gas wells have been drilled in the field, and 53 of them are now producing. Nine of the thirteen wells drilled in 1909 are still producing, though during 1917 about a dozen wells were exhausted and abandoned. Nearly all the producing wells were drilled by oil companies in the search for oil, and in many wells much gas was wasted before the well was taken over by the gas company.

The following table gives statistics of the decline of rock pressure and open flow and also the quantity of gas marketed by the Lone Star Gas Co. The figures showing production for 1916 and especially for 1917 are low, for during these years much gas was lost through pipe-line leaks. The total gas marketed by the Lone Star Co. to date is about 60 billion cubic feet, and it is probable that nearly 10 billion cubic feet has been marketed by other companies. It seems safe to assume that 20 billion cubic feet has been used for fuel in the field, wasted in drilling or repairing wells, and lost through pipeline leaks, making a total of approximately 90 billion cubic feet removed from the sands.

Rock pressure, open-flow capacity, and partial production of Petrolia field, 1910-1918.

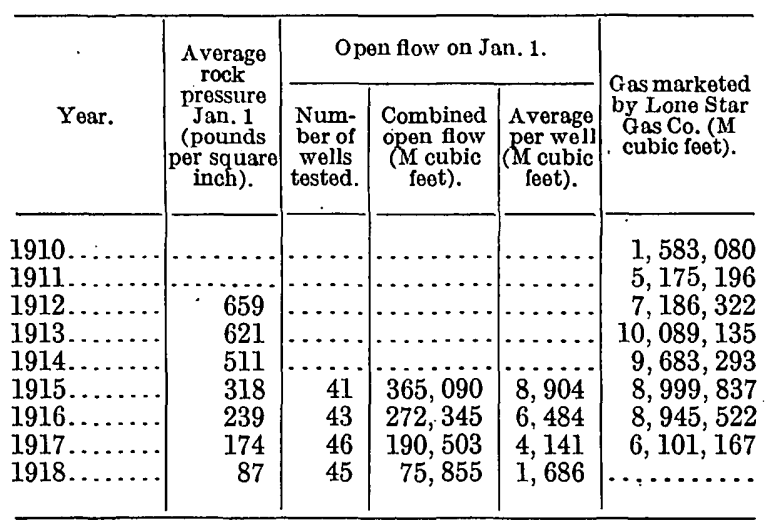

DURATION OF THE SUPPLY.

Figure 16 shows graphically the decline of average rock pressure and the number of wells producing by months from 1912 to 1918 . The decline of average open-flow capacity from January 1, 1915, to January 1, 1918, is also shown. The curve sketched in the diagram indicates that the pressure will reach zero in 1921. However, as the form of the curve for past years has been determined partly by the production of the field, which reached 45 million cubic feet on certain days during the winter of $1917-18$, it is evident that if the production of the field were reduced to 12 or 15 million feet a day the curve would flatten and the field's life would be extended by a number of months. 
Any new wells drilled in largely exhausted territory will tend to steepen the curve, unless production is held back, but wells drilled in relatively undepleted areas will, if successful, raise and flatten the curve. It will doubtless also be possible to reduce the line pressure below atmospheric pressure and thus extend the field's life beyond the point indicated.

In 1916 Shaw ${ }^{46}$ estimated the original volume of gas in the Petrolia field to be 120 billion cubic feet, using the following factors: Area of the field, 15 square miles; average thickness of sand, 30 feet; porosity of sand; 20 per cent; and original rock pressure, 725 pounds to the square inch. In 1918 the writer made an independent estimate on the basis of somewhat lower than would be expected from the estimate of the total gas marketed and wasted (90 billion cubic feet). The discrepancy may be due to the fact that the field contains several areas which are probably productive but which have never been drilled and in which, therefore, the pressure is considerably above 82 pounds to the square inch. If these areas prove to be productive, the true average pressure for the field in July, 1918, was probably over 100 pounds, and the quantity of gas remaining was probably nearer 25 billion cubic feet.

On the other hand, it must be recognized that the foregoing method of estimating the volume of gas remaining is likely to give results somewhat too high, for it is based on.the

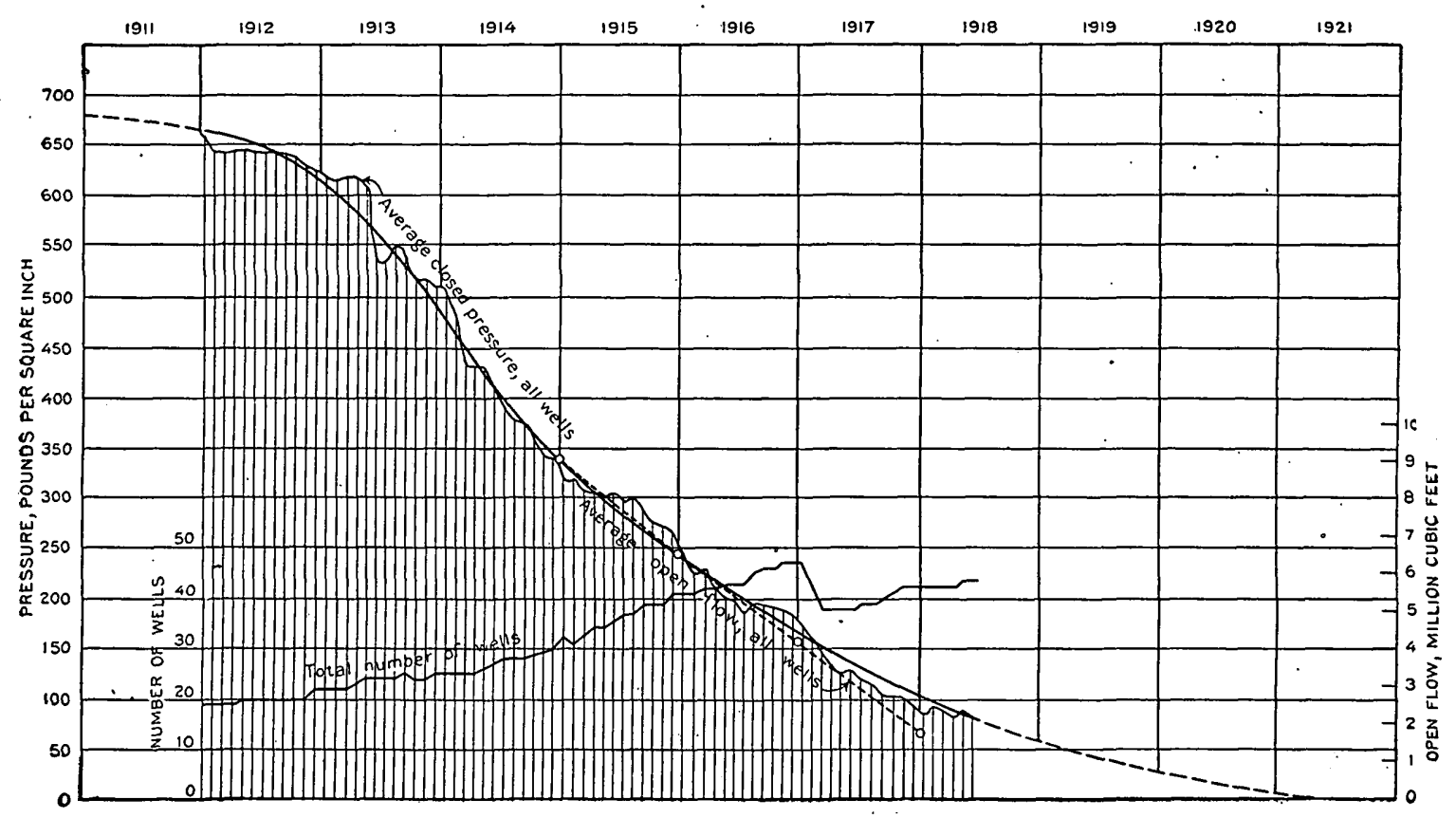

FiguRE 16.-Curve showing average closed pressure and average open flow of gas wells of Lone Star Gas Co. in the Petrolia field, Tex.

different factors but arrived at the same figure. If we assume for the moment that the decline in rock pressure is an exact index of the decrease in volume of gas in the sand, and accept 120 billion cubic feet as the original volume, it is obviously possible to calculate the amount remaining in the sands at any given date. For example, in July, 1918, when the average rock pressure was 82 pounds to the square inch, it would appear that about $13 \frac{1}{2}$ billion cubic feet of gas remained in the sands, or a supply of 15 million cubic feet a day for $2 \frac{1}{2}$ years. This is somewhat lower than the estimate based on the curve showing decline in pressure and is also

16 Op. cit.. pp. 36-40. assumption that the decline in rock pressure is due wholly to the removal of gas and is not affected by other conditions. If the pressure is being partly maintained by water in the sands, which migrates up the dip as the gas is removed, it is evident that the calculated volume of gas may be considerably greater than the true volume. In the Petrolia field there are some indications that water may be following the gas up the dip and thus maintaining the pressure to some extent, though water troubles have not been serious. Most of the old wells show some water, but it is probably top water that is leaking down behind the casing rather than water in the gas sands. 
POSSIBUITY OF EXTENSIONS OF THE FIELD.

Although the two foregoing estimates agree in placing the life of the field at two and onehalf to three years from the middle of 1918 , experience in other areas indicates that several factors tend to prolong the life of a field somewhat beyond the period estimated. Few if any fields are known that were capable of supplying as much as 45 million cubic feet a day against positive line pressure in the third year before their complete exhaustion. The chief factors tending to prolong the life of a field are the probability of discovering small extensions of the field and the tendency in the later part of the life of a field toward more efficient conservation and toward the utilization of small flows.

The Petrolia field is now pretty well bounded by dry holes, and there is no reason to expect any important extension of the producing area, but there are several small undrilled districts which appear promising. The largest of these is the supposed branch anticline on the northeastern slope of the main fold, which includes at least a square mile of undrilled territory. (See fig. 15.) Another possible area is at the south edge of the field, in blocks 61,71 , and 72 . There are several wells in this area listed as dry holes, but at least one of them is reported to have had a daily capacity of about 7 million cubic feet. In the western part of the field there is also a strip of territory about half a mile wide and $1 \frac{1}{2}$ miles long, which has not been properly tested. Finally, there is a possibility of finding a small pool of gas about 2 miles west of the main field. An old well about a mile west of the field has been producing enough gas to furnish fuel for drilling wells for years. About a mile still farther west is a group of oil wells about 1,000 feet deep and one gas well which found a sand yielding 6 million cubic feet a day at a depth of 1,671 feet, or about the horizon of the gas sands in the main field. The gas from this well was sampled and found to contain 1.18 per cent of helium.

The chance of increasing the supply by finding deeper sands, however, is not particularly promising, as a number of deep wells on the outskirts of the field have encountered a great thickness of hard, water-bearing limestone at a depth of about 2,000 feet. There are, however, about eighteen gas wells within the field which do not penetrate the entire gas-bearing zone, and these wells could doubtless be improved by deepening.

Aside from the probability of extending the field, the effects of rigid conservation should be considered. The Petrolia gas is too high in nitrogen to be entirely satisfactory as a fuel, but it is rich in the higher hydrocarbons, which are condensed as gasoline, and it also has a special value as a source of helium. For these reasons it should be possible with the powerful compressor plant already installed to handle profitably wells with flows as low as half a million cubic feet a day; and whether many large wells can yet be brought in around the edges of the field or not, it is fairly certain that a number of such small wells can be developed. Moreover, the value of the gas justifies every precaution to reduce the waste of gas during drilling, as well as to keep the wells operating at the highest standard of efficiency.

OTHER FIELDS IN NORTHERN TEXAS.

In 1916, when a careful survey of the gas resources of northern Texas was made by Shaw and Matson, ${ }^{47}$ the only large fields were the Petrolia and Mexia-Groesbeck fields. Since that time, however, the great oil and gas pools in the Ranger region have been discovered, and an enormous potential production of gas has already been developed. All sources of supply in the Ranger region and elsewhere in northern Texas were sampled in the summer of 1918 , but none of the gases were found to be rich in helium. None of these gases, however, occur at the horizon of the Petrolia gas, and as the limits of the producing areas are still undefined and prospecting is still active it is possible that supplies of helium-rich gas will yet be discovered.

The Electra and Burkburnett fields, a short distance west of Petrolia, produce only oil, which is derived from about the same horizon as the gas at Petrolia. Still farther west, in the central part of Wilbarger County, four wells drilled some years ago found small supplies of gas probably at a horizon somewhat above that of the productive sands at Petrolia. These wells are now exhausted, and no samples of the gas could be obtained.

On the Matthews ranch, in the southern part of Throckmorton County, five wells have been 47 Shaw, E. W., Matson, G. C., and Wegemann, C. H., op. clt. 
drilled, two of which found small volumes of gas at a depth of 1,050 feet. One of the wells was abandoned after two years of very moderate use, and the other had in July, 1918, an open flow of less than half a million cubic feet a day. Two samples of the gas tested for helium showed 0.22 and 0.73 per cent. The district was not visited by the writer, but in the opinion of the operator who drilled the wells there is little prospect of developing a commercial supply of the gas.

The Moran field, in the southeast corner of Shackelford County, contains about a dozen gas wells and a somewhat larger number of oil wells. One of the gas wells is 2,930 feet and another about 2,700 feet deep, but the others are approximately 2,000 feet deep. The open flow of the wells ranges between 3 million and 15 million cubic feet a day, and in July, 1918, the daily capacity of the field was perhaps 15 or 20 million cubic feet. Five samples of Moran gas were tested and found to contain from 0.27 to 0.41 per cent of helium. A pipe-line sample collected in January, 1918, contained 0.38 per cent, but a pipe-line sample collected in July showed only 0.27 per cent.

In the Ranger, Caddo, and Breckenridge fields, in Stephens and Eastland counties, oil and gas are produced chiefly from the Smithwick shale and Marble Falls limestone at depths of 3,000 to 3,500 feet, and this gas contains less than 0.1 per cent of helium. One well in the Breckenridge field, however, found gas in the Strawn formation at a depth of 2,230 feet and a sample of this gas carried 0.44 per cent of helium.

In the La Casa field, in Stephens County, and in the Strawn and Mineral Wells fields, in Palo Pinto County, large volumes of gas are produced from the Strawn formation. Two samples of gas from these fields showed only a trace of helium, and six others carried between 0.17 and 0.32 per cent, but the richer samples represent only a very small part of the supply. (See p. 106.)

Gas has been found in several wells near Bangs, in the western part of Brown County, and two samples of this gas contained 0.35 and 0.38 per cent of helium. A sample of gas from a well south of Coleman, in Coleman County, contained 0.22 per cent of helium, but the gas of the Trickham field; about 20 miles to the southwest, contains none.
APPALACHIAN REGION.

VINTON COUNTY FIELD, OHIO.

The field in Vinton County, Ohio, as at present developed centers in Richland Township (T. 9 N., R. 18 W.), but development is extending into the neighboring townships and the limits of the field are not yet defined. The field lies about 60 miles south of Columbus and about 3 miles west of the town of McArthur, on the Hocking Valley Railroad.

The main producing sand in the Vinton County field is in the Clinton sand, which is encountered at depths ranging between 1,700 and 2,400 feet. (See p. 102.) The accumulation of gas is not controlled by folding of the rocks but chiefly by the fact that the eastwarddipping Clinton sand feathers out and merges into shale in the western part of the county, the gas having apparently migrated up the dip and collected in the thinning edge of the sand. Similar conditions prevail along the strike of the rocks as far to the north as Cleveland, ${ }^{48}$ and the sand is thus productive in many areas in a broad belt extending north and south in central Ohio. (See fig. 5.) The sand is somewhat variable in porosity and, of course, does not everywhere yield gas, but the Clinton fields, broadly considered, form an almost continuous belt of productive territory. The Vinton County pool lies at the southern extremity of the belt and is separated from the main fields by an area that has not yet proved pro- . ductive, though a small pool has been discovered in the southern part of Hocking County, about 8 miles north of the main Vinton field. The gas in the Hocking County pool contains less helium than that in the Vinton field, and most of the Clinton gas north of Logan contains little nitrogen, and is presumably very poor in helium. It would therefore appear that the area in which the Clinton gas may be regarded as a source of helium does not extend far north of Hocking County; its southern limit, however, remains to be determined.

Drilling in the Vinton County area became active in 1915. In September, 1918, there were about 180 producing wells in the county, having an estimated potential production of 65 million cubic feet a day. As considerable areas that may be regarded as practically

48 Rogers, G. S., The Cleveland gas field, Cuyahoga County, Ohio: U. S. Geol. Survey Bull. 661, pp. 1-68, 1918. 
proved remain to be drilled, it is believed that the production could be increased to 100 million cubic feet a day and could be maintained at this figure for several years. The rock pressure of the wells in September, 1918, averaged about 700 pounds to the square inch.

Eighteen samples of Clinton gas from the Vinton County field showed an average helium content of 0.37 per cent, the extremes being 0.48 and 0.20 per cent. (See p. 102.) Two samples of gas from a sand near the horizon of the Berea, about 1,800 feet stratigraphically above the Clinton, contained 0.39 and 0.40 per cent, but the volume of this gas available is insignificant in comparison with that of the Clinton gas. Two samples of Clinton gas from the small pool in Hocking County contained 0.30 and 0.32 per cent of helium.

On the assumption that the Vinton County field is capable of producing 75 million cubic feet daily of gas carrying 0.37 per cent of helium, it is evident that the daily production of helium would be 277,500 cubic feet, which is more than twice as much as the Petrolia field is capable of producing. The utilization of the Vinton County gas as a commercial source of helium, however, depends entirely on conditions limiting the process of extraction. The results so far obtained in the experimental plants at Fort Worth indicate that the expense of treating a gas carrying only 0.37 per cent of helium, by either the Linde or the Claude process, would be prohibitive, but the JeffriesNorton process offers promise of reducing the cost to a point at which such a gas could be profitably treated. If this can be done the large volume of gas available in Vinton County and its high pressure render the field very attractive as a source of helium.

\section{ROCKY MOUNTANN AND PACIFIC COAST REGIONS.}

Gas containing about 0.3 per cent of helium has been found at three localities in the Rocky Mountain and Pacific coast regions, but the volumes available do not appear to be large. In view of the low helium content of the gas, the uncertainty as to the volume of the supply, and the location of the fields at considerable distances from manufacturing centers, these areas can not at present be regarded as commercial sources of helium. The main fea- tures of these fields have been described on pages 32-33.

\section{AVAILABLE SUPPLY OF HELIOM IN THE UNITED} STATES.

Gas fields are usually short lived in comparison with oil fields, but local conditions cause so much variation in the way in which gas wells are handled that it is impossible to formulate any rule as to the length of the productive period.

The maximum possible production of a gas well is its open flow - that is, the volume of gas that it is capable of delivering against atmospheric pressure-but if the well is allowed thus to flow open its yield diminishes very rapidly. In every field it is customary to maintain a definite pressure in the pipe line to which the well is attached and thus prevent the well from producing more than a part of its capacity. In some fields, however, the demand is such as to warrant taking 50 or 60 per cent of the open flow, whereas in others the production is held down to 20 or 25 per cent. By holding back the production the life of the field is of course lengthened and water troubles are more likely to be avoided, thus possibly increasing the total volume of gas ultimately recovered.

Because of this variation in operating conditions, no estimate of the available supply of helium that could be given here would have any permanent value; and furthermore, until processes of extraction are perfected it will be uncertain how lean a gas can be profitably treated. In September, 1918, the writer estimated that the Petrolia, Eldorado, Augusta, Dexter-Otto, and Sedan districts, all of which yield gas averaging more than 0.85 per cent of helium, were capable of producing a total of 363,800 cubic feet of helium daily for the next two and one-half to three years, provided some additional drilling were done and that the production were held down to 20 or 25 per cent of the open flow. Conditions have changed since the estimate was made, however, for during the winter of 1918-19 some of these fields produced considerably more than 20 to 25 per cent of their open-flow capacity, and the amount of gas remaining in the sands has been correspondingly decreased.

If gas containing as little as 0.5 per cent of helium can be profitably treated, the Pearson field and the neighboring territory will probably 
furnish a large supply, and it also appears probable that the western Osage country will yield gas carrying at least as much helium as that of the Pearson field. If gas containing as little as 0.37 per cent of helium can be treated, the Vinton County field is capable of furnishing at least a quarter of a million cubic feet of helium daily for several years. Taking into account every field producing at least 3 million cubic feet a day of raw gas containing at least 0.35 per cent of helium, the writer estimated in September, 1918, that a weekly production of about, 6 million cubic feet of helium (not counting losses in extraction) could be maintained for two and one-half to three years.

As the extraction of helium in large quantities involves the installation of powerful compressors and other expensive machinery, it is obviously desirable to start operations in a field which is still young and in which the rock pressure is still high. Furthermore, it is desirable that the operations shall be aimed primarily at recovering the helium content of the gas and that the production be maintained, summer and winter, at a constant figure equal to the capacity of the extraction plant, thus prolonging the life of the field and extending the period of usefulness of the plant. Most of the helium-bearing fields of Kansas are now old and their product is in great demand as fuel, but the Pearson field, in Oklahoma, and the Vinton County field, in Ohio, are still comparatively young, and much of their product could be used as a source of helium without disturbing the local market. If new fields of helium-rich gas are discovered in the western Osage country or in northern Texas the operating conditions. will of course be even more favorable.

\section{POSSIBLE SOURCES OF HELIUM IN OTHER} COUNTRIES.

As the conditions governing the occurrence of helium are very imperfectly known, it is impossible to forecast the importance of the supplies that may be developed in other countries. It may be of interest, however, to review the occurrences of helium abroad, as described in the literature, and to consider also the application to foreign fields of the principles that seem to govern the occurrence of helium in the United States.

So far as can be judged from the literature, no commercial supplies of helium-bearing nat- ural gas have yet been discovered outside of North America. According to the writer's information, the richest gas in Caniada is that of the Bow Island field, Alberta, which contains 0.30 per cent of helium and of which at the present time an open flow of about 15 million cubic feet is available. It is reported that attempts to extract the helium from the Bow Island gas have not been successful, though with an improvement in the extraction processes this gas may yet become a commercial source. Furthermore, considerable quantities of oil and gas are produced in other parts of Canada, where the conditions of occurrence are similar to those in the United States, and it is not unlikely that gas richer in helium than that of the Bow Island field will be discovered.

As described on pages 33-34 all but one of the European natural gases that have been tested contain negligible proportions of helium. The only gas rich enough to be considered a possible commercial source is the gas obtained from the deep test hole at Pechelbronn, Alsace, which contains 0.38 per cent of helium, but apparently only a very small volume of this gas is available.

It would of course be unwise to infer, from the results of half a dozen tests, that no heliumbearing natural gas occurs outside of North America, though several lines of reasoning lead to the conclusion that such gas is less likely to be found in the other continents. In the first place, the United States, which has contributed 60 per cent of the world's total output of oil, has furnished a very much larger proportion of the world's output of gas. This is doubtless due partly to the fact that most foreign petroleum regions are inaccessible and remote from centers of industrial activity, so that there is little market for the gas that may be found; but it seems safe to conclude, nevertheless, that natural gas is far more abundant in the United States than in any other country yet explored for petroleum. The only gas field in Europe comparable in size to the great North American fields is in Transylvania, and the several samples of gas from that field that have been tested contain practically no helium. As natural gas is more plentiful in the United States than elsewhere, it might be argued, simply on the theory of chances, that the helium-bearing variety is also more plentiful. 
The conditions under which helium-bearing natural gas occurs in the United States also suggest that such gas is less likely to be found in other countries, though it must of course be recognized that these conditions may not prove to be of universal application. Except in the United States, Canada, and China, the world's output of oil and gas is at present derived wholly from Cretaceous and Tertiary strata, and in the United States the Cretaceous and Tertiary gases are characteristically poor in helium. Only about a dozen samples out of the seventy-five tested contained measurable proportions of helium, and only two contained as much as 0.3 per cent. The occurrence of 0.3 per cent in two samples indicates that there is no fundamental reason why helium should not occur in Cretaceous and Tertiary gases, but the large number of samples that contain no helium whatever suggest that such occurrences are rare. Finally, all heliumbearing natural gases in the United Stares are rich in nitrogen, whereas the many analyses of European gases that have been published show. in general a low nitrogen content. ${ }^{49}$ Only two accounts of high-nitrogen gas in Europe have come to the writer's attention-the deep gas at Pechelbronn, which contains 46.55 per cent of nitrogen and 0.38 per cent of helium (see p. 34), and a gas discovered in 1906 at Nowo-Usensk, in the Government of Samara, Russia. Two analyses of this gas showed 20.70 and 40.86 per cent of nitrogen, but the proportion of helium was undetermined..$^{50}$ Charitschkoft, ${ }^{51}$ however, stated in 1907 that many of the Russian gases are rich in nitrogen and should be tested for helium, but that up to that time no search for helium had been made.

It is not to be inferred from the foregoing remarks that helium has not been found in

10. Ingler has compiled a great many analyses of gas from various European countries. A number of theso analyses show a high nitrogen content but also a high proportion of oxygen, indicating that the sample was contaminated by air. Engler, C., Das Erdöl, Band 1, pp. 738-744, Loipzig, 1913.

so The analyses also show 4.22 and 10.65 per cent of hydrogen and may therefore bo regarded with some suspicion. Doss, B. Über das Naturgasbohrloch auf dem Guto der Gebrüder Melnikow im Kreise NowoUsensk, Gouvernement Samara.[abstract]: Geol. Centralblatt, vol. 13, p. 8, 1909; Eino ncue Lagerstïtto von Naturgas in Russland [abstract] Idom, p. 455; Über das dritte Gasbohrloch auf dem Gute der Gebrüder Molnikow im Gouverment Samara nebst crgänzenden UntersuchunMon ilb

ol Charitschkoff, K., Neue Mitteilungen über die Naphtachemie: Petroleum Zcitschr., vol. 2, p. 712, 1907. quantity outside of North America, for as described on pages $47-51$, the gases of a number of European mineral springs and fumaroles and the fire damp of some European mines carry helium. The gases of three mineral springs at Santenay, France, carry more than 8 per cent of helium, or more than four times as much as the richest natural gas in the United States. The supply of these gases available, however, is small, and the total volume of helium emitted by these three springs in the course of a year amounts to less than 1,000 cubic feet, or only a fraction as much as the average well in the Petrolia field yields daily. (See p. 87.) A spring at Néris, France, which emits gas containing 0.97 per cent of helium and produces about 1,200 cubic feet of helium yearly, appears to be the most productive single source of.gas rich enough to be treated on a commercial scale. The mine gases, on the other hand, carry large volumes of helium, but the percentage is so small that the helium could not be profitably extracted. The coal mine at Anzin, France, for example, emits about 154,000 cubic feet of helium yearly, but the proportion of helium in the gas is only $0.044 \mathrm{per}$ cent. (See p. 47.) The mineral springs and mine gases of Europe have been thoroughly investigated by Moureu and his associates, and it is improbable that any commercial sources of helium will be discovered among them.

The Italian fumarole and volcanic gases seem more likely to yield helium in commercial proportions and volume, though the richest gas recorded in the literature contains only 0.0155 per cent of helium. (See p. 51.) The helium content of many other similar gases was investigated during the war by the Italian authorities, and unsuccessful attempts were made to extract the helium on commercial scale for use in balloons. It has been reported, however, that gas containing 4 per cent of helium has recently been discovered in the boric-acid soffiones of Tuscany. As shown by the analyses on page 51, such gas generally consists chiefly of carbon dioxide and hydrogen sulphide, and as these constituents can easily be removed by chemical methods the extraction of only 1 per cent of helium from such a gas would not be difficult. 



\section{SAMPLES OF NATURAL GAS TESTED FOR HELIUM.}

The following list is designed as a complete catalogue of all samples of natural gas whose helium content had been determined prior to December 10, 1918. Samples collected in the field but lost through leaky contriners or otherwise before tests were made are not included. The samples are grouped by States, counties, and fields, each in alphabetic order.

Most of the samples were collected by the writer and by members of the Geological Survey assisting him during the summer of 1918. Most of the samples from Wyoming, however, were collected during September, 1918, by C.A. Fisher, a former member of the Survey, and most of those from the Northwestern States and from California were collected by A. W. Ambrose and E. W. Wagy, of the Bureau of Mines, during August and September. Fairly complete data as to the name, location, depth, pressure, flow, and producing horizon of all wells sampled by Survey members and by Fisher, Ambrose, and Wagy are given in the tables. In order to make the catalogue as complete as possible the tests of a number of samples collected by C. F. Ward, of the Bureau of Mines, early in 1918, and by Cady and McFarland in 1906-7, are also included, despite the fact that all particulars regarding the source of many of these samples are not available.
The name of the collector of each sample is indicated by the letter prefixed to the sample number, as follows:

C 1-54, Cady and McFarland, 1906-7 (mostly Kansas).

W, C. F. Ward, 1917-18 (Oklahoma, Texas, Louisiana, California, etc.).

1-100, G. S. Rogers, June-September, 1918 (Kansas, Oklahoma, Texas).

Ry 1-101, P. V. Roundy, August-October, 1918 (Kansas).

D 1-13, C. E. Dobbin, August-September, 1918 (Oklahoma).

F 1-14, C. A. Fisher, September, 1918 (Wyoming).

A 1-70, A. W. Ambrose, August-September, 1918 (Northwestern States and California).

Ri 1-23, G. B. Richardson; August-September, 1918 (Ohio).

Samples C 1-54 were analyzed by Cady and McFarland at the University of Kansas; many of those marked $\mathrm{W}$ were tested by H. P. Cady or his assistants; and the remainder were tested by C. W. Seibel, of the Bureau of Mines, at the laboratory of the Fort Worth gas experiment plant.

In the tables the figures given for rock pressure and open flow are those recorded on the date the sample was collected unless otherwise specified. 


\begin{tabular}{|c|c|c|c|}
\hline & & & Well. \\
\hline Sample No. & County. & Field. & 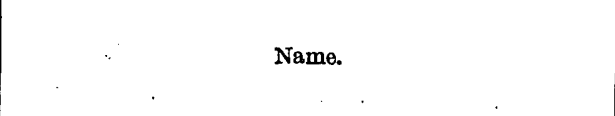 \\
\hline 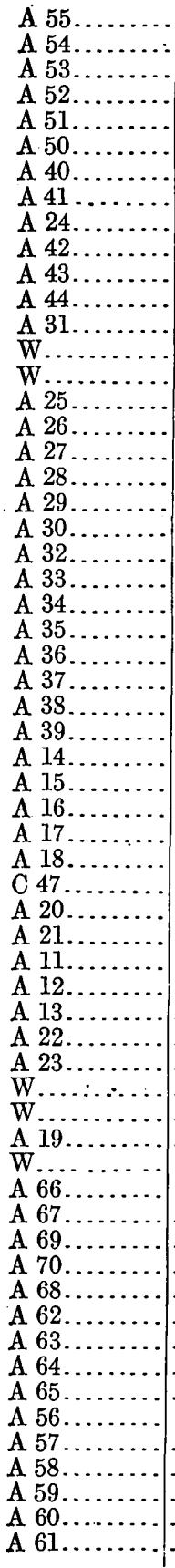 & 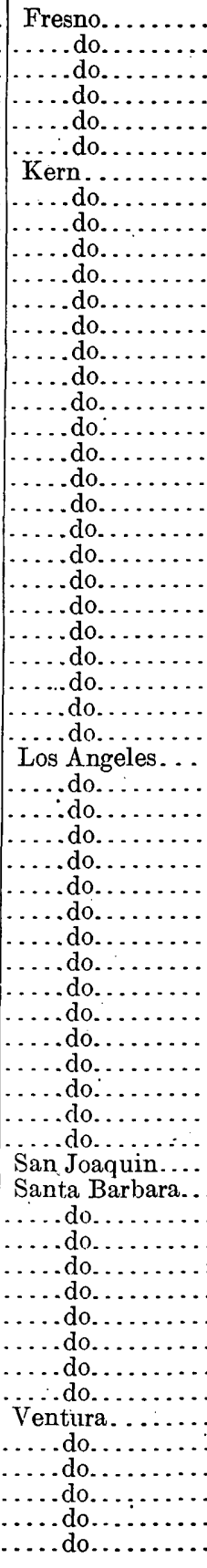 & 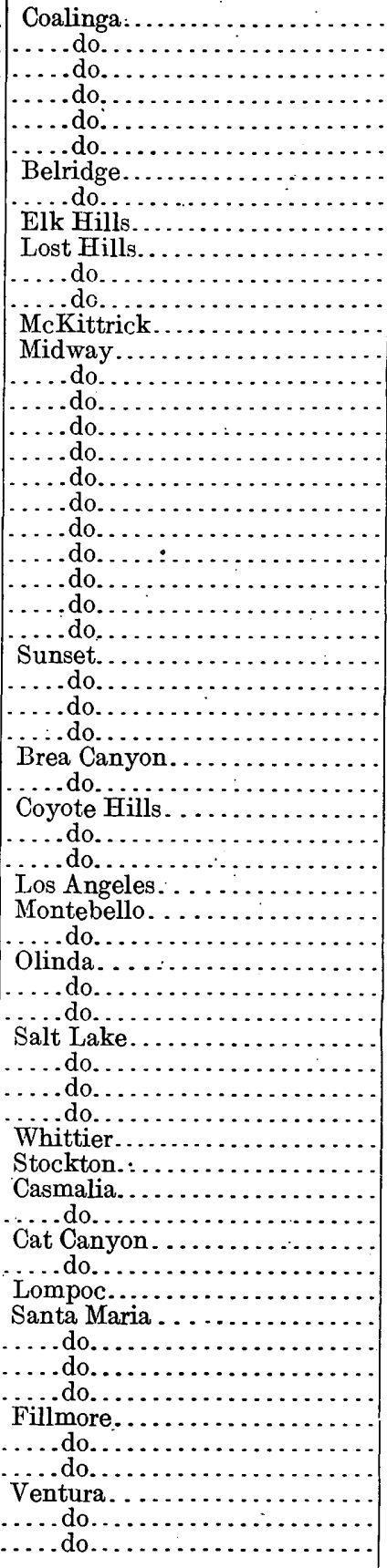 & 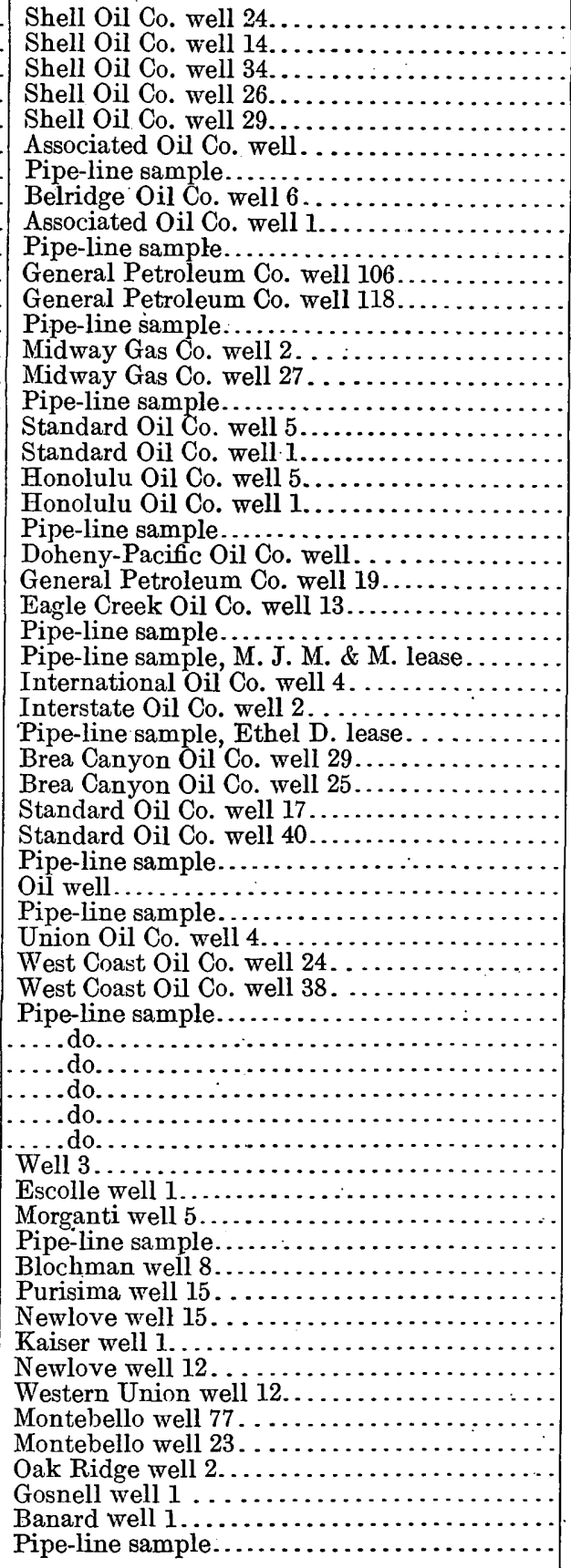 \\
\hline \multicolumn{4}{|c|}{ Colorado. } \\
\hline & & De Beque......... & \\
\hline
\end{tabular}

a A verage depth of wells, 3,000 feet.

$b$ Middle oil sand.

$c$ Upper oil sand.

$d$ Combined flow of all wells on lease. 
tested for helium.

California.

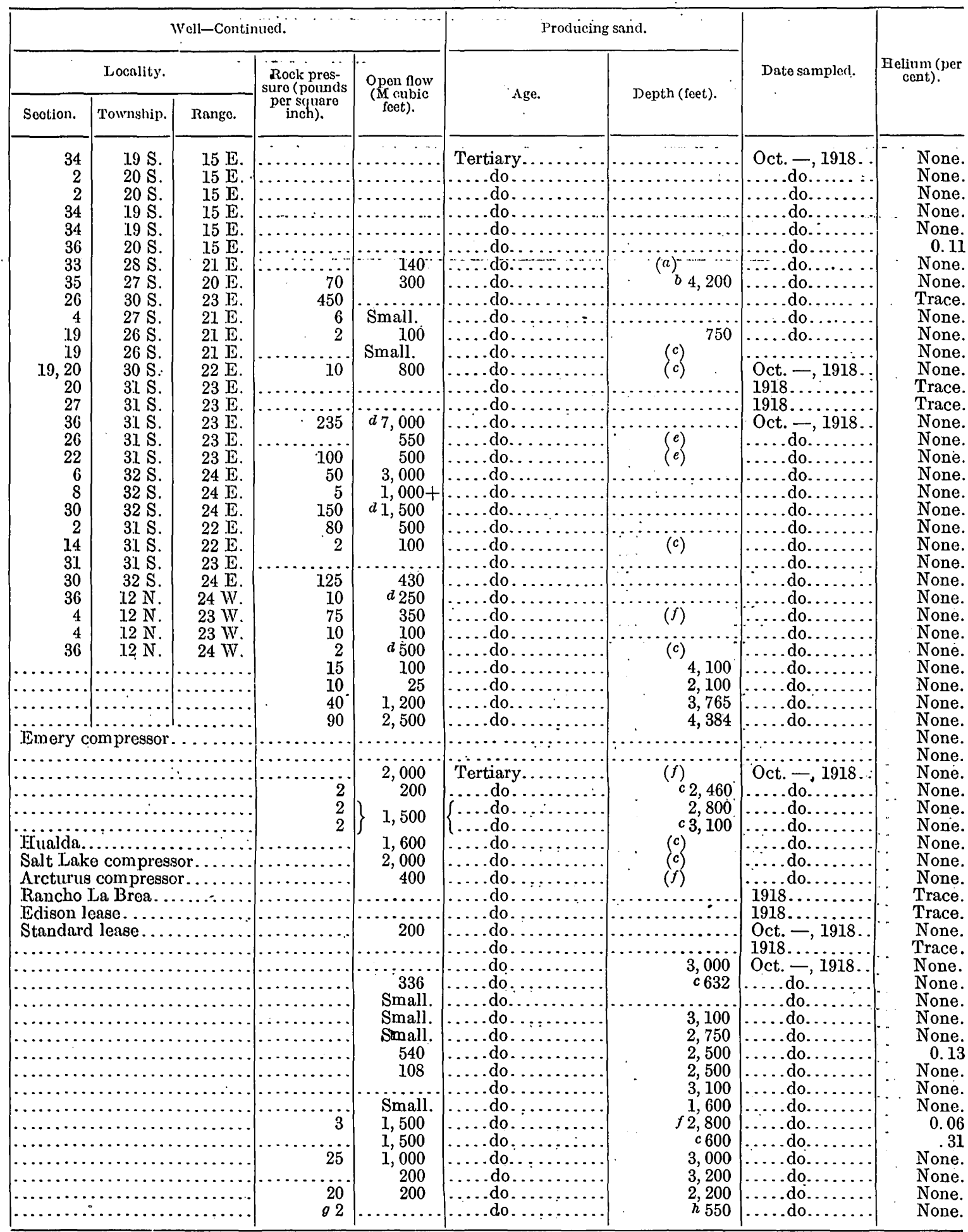

Colorado.

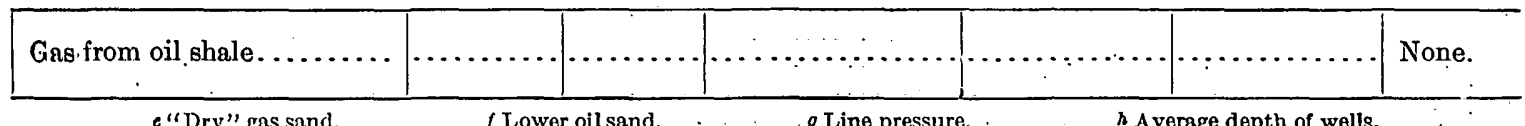


Indiana.

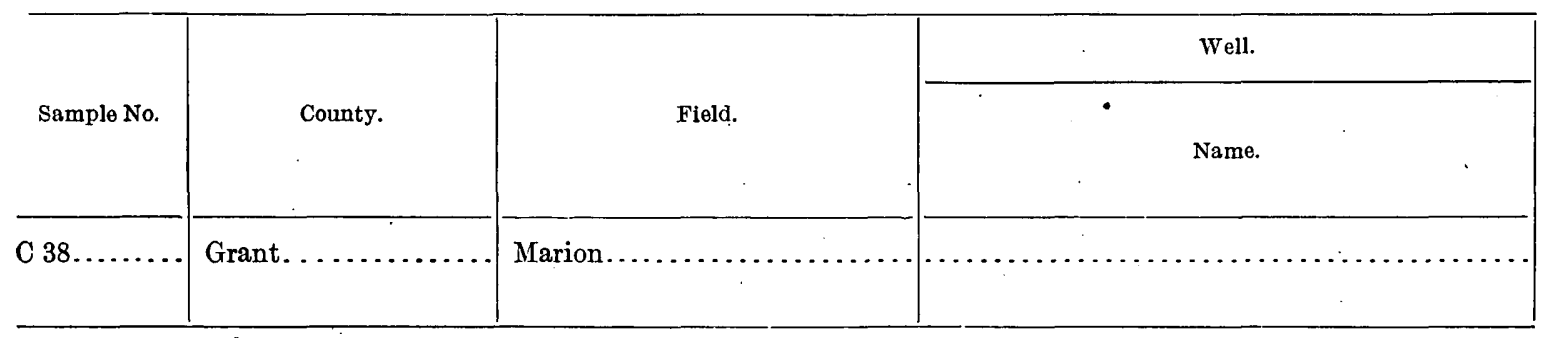

Kansas.

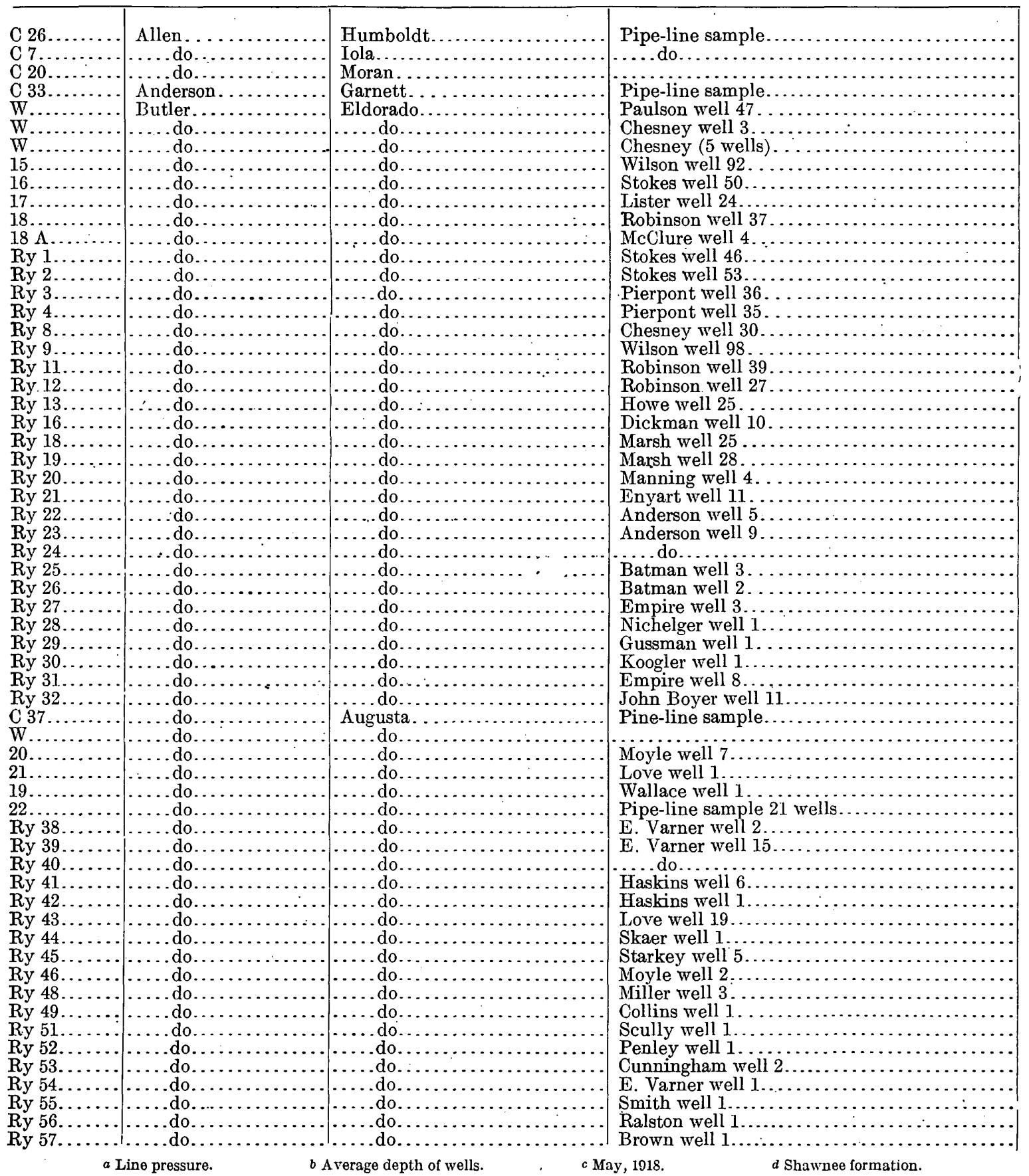


tested for helium-Continued.

\begin{tabular}{|c|c|c|c|c|c|c|c|c|}
\hline \multicolumn{5}{|c|}{ Well-Continued. } & \multicolumn{2}{|c|}{ Producing sand. } & \multirow{3}{*}{ Date sampled. } & \multirow{3}{*}{$\begin{array}{c}\text { Helium (per } \\
\text { cent). }\end{array}$} \\
\hline \multicolumn{3}{|c|}{ Locality. } & \multirow{2}{*}{$\begin{array}{l}\text { Rock pres- } \\
\text { sure (pounds } \\
\text { per square } \\
\text { inch). }\end{array}$} & \multirow{2}{*}{$\begin{array}{l}\text { Open flow } \\
\text { (M cubic } \\
\text { feet). }\end{array}$} & \multirow{2}{*}{ Age. } & \multirow{2}{*}{ Depth (feet). } & & \\
\hline Soction. & Township. & Rango. & & & & & & \\
\hline$\cdots \ldots \ldots$ & $\ldots$. & . & $\ldots \ldots$ & & $\begin{array}{l}\text { Ordovician (Tren- } \\
\text { ton ?). }\end{array}$ & $\ldots \ldots \ldots$ & Aug. 25,1906 & 0.167 \\
\hline
\end{tabular}

Kansas.

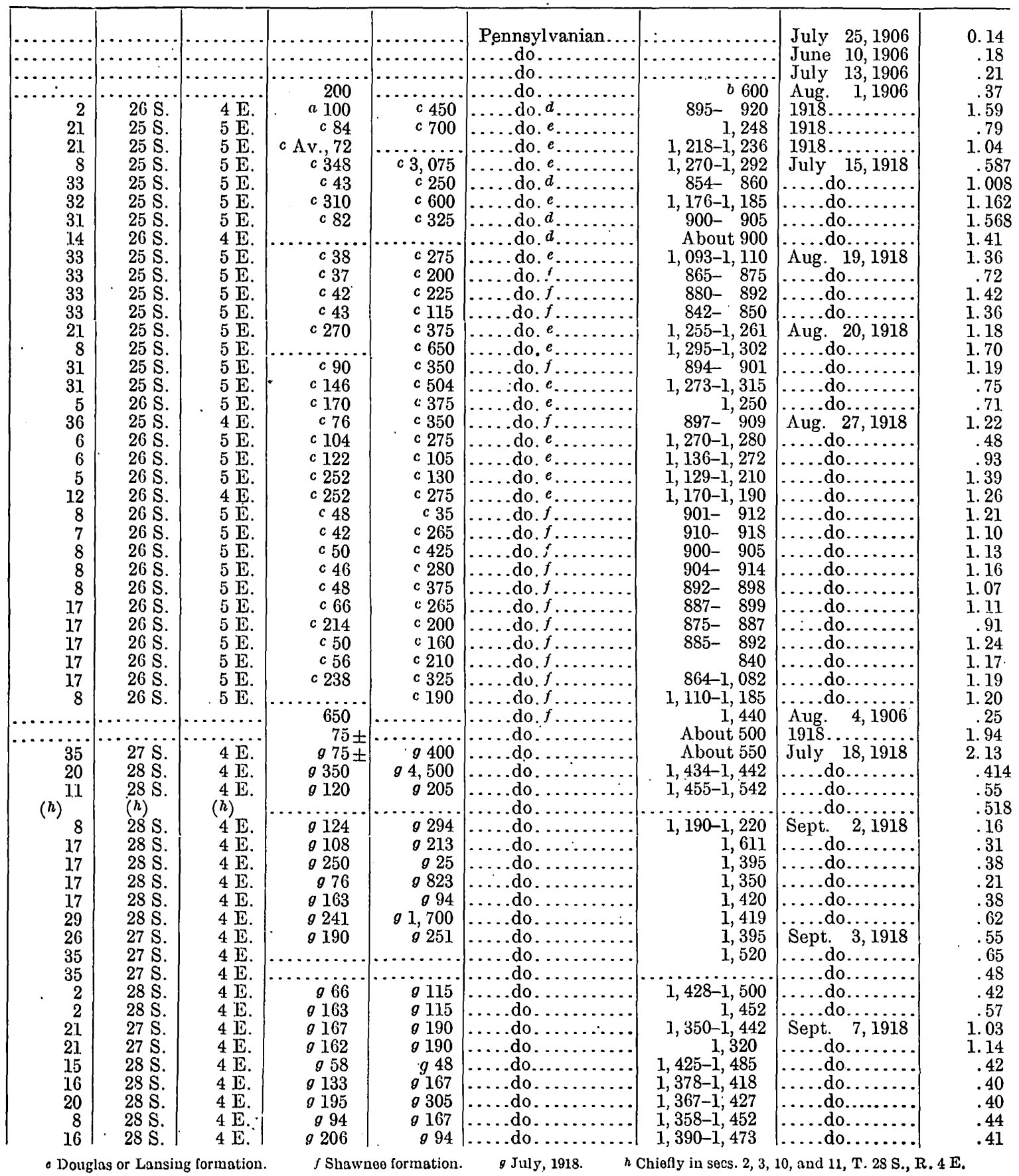


Kansas-Continued.

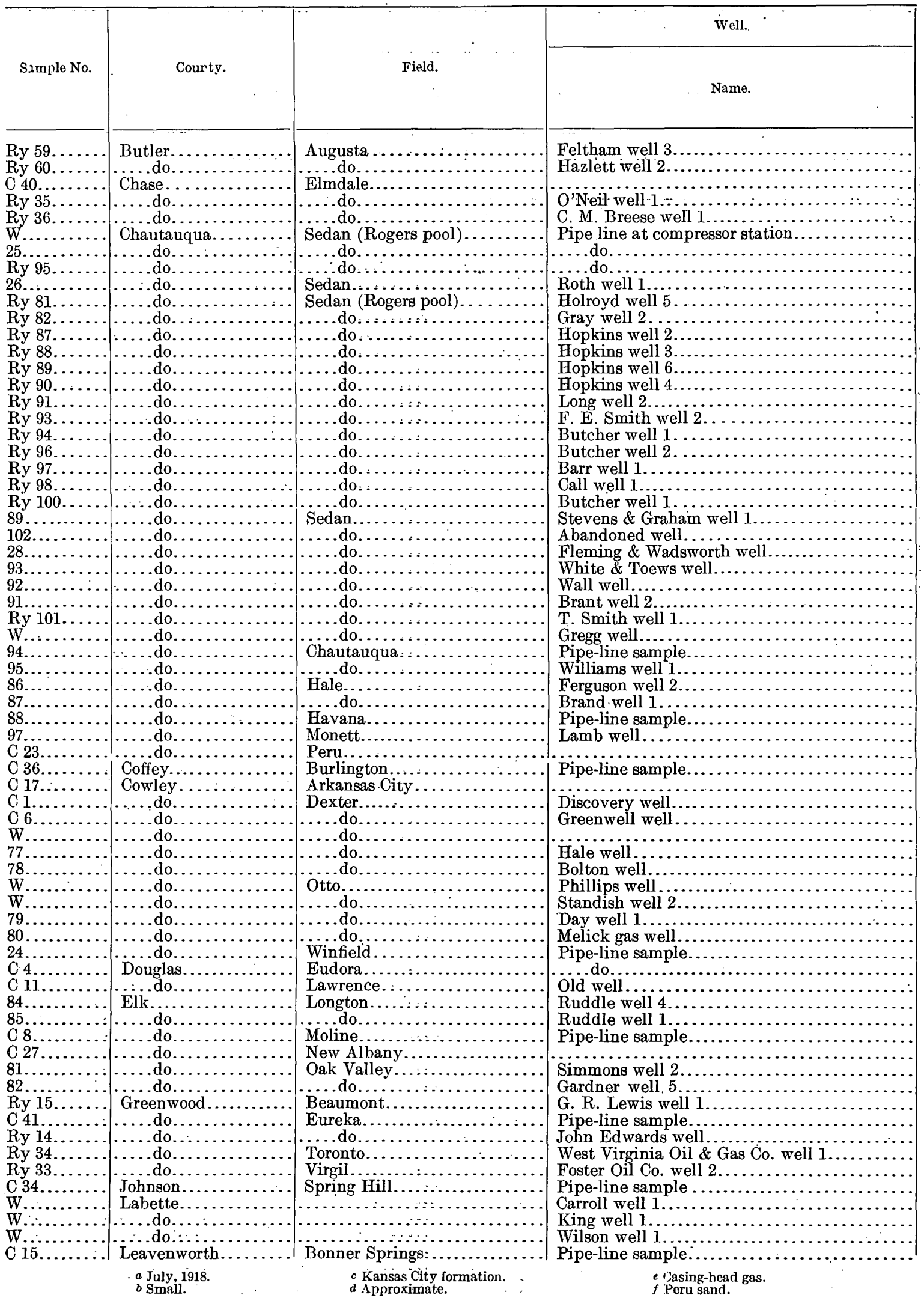


tested for helium-Continued.

Kansas-Continued.

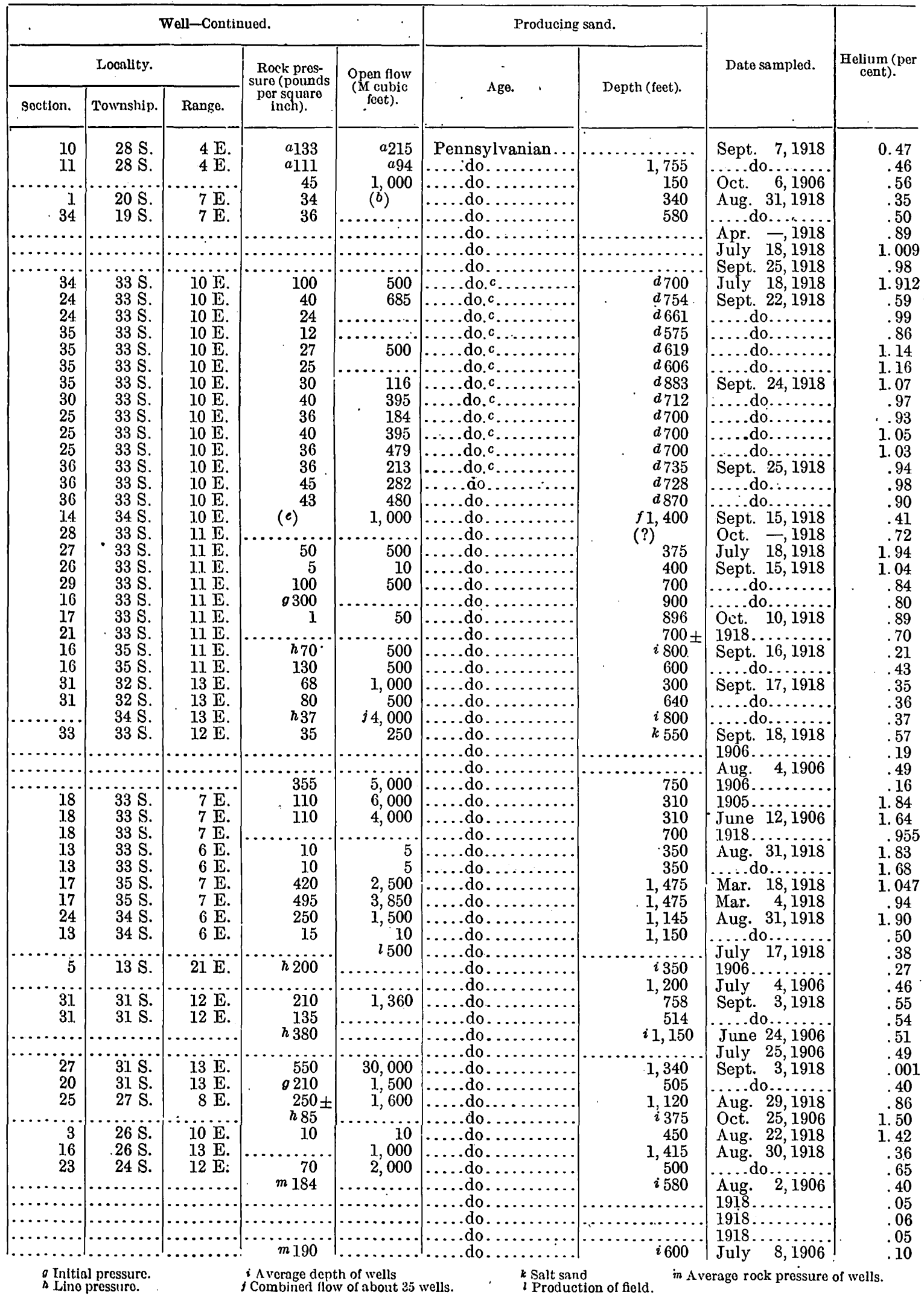


Kansas-Continued.

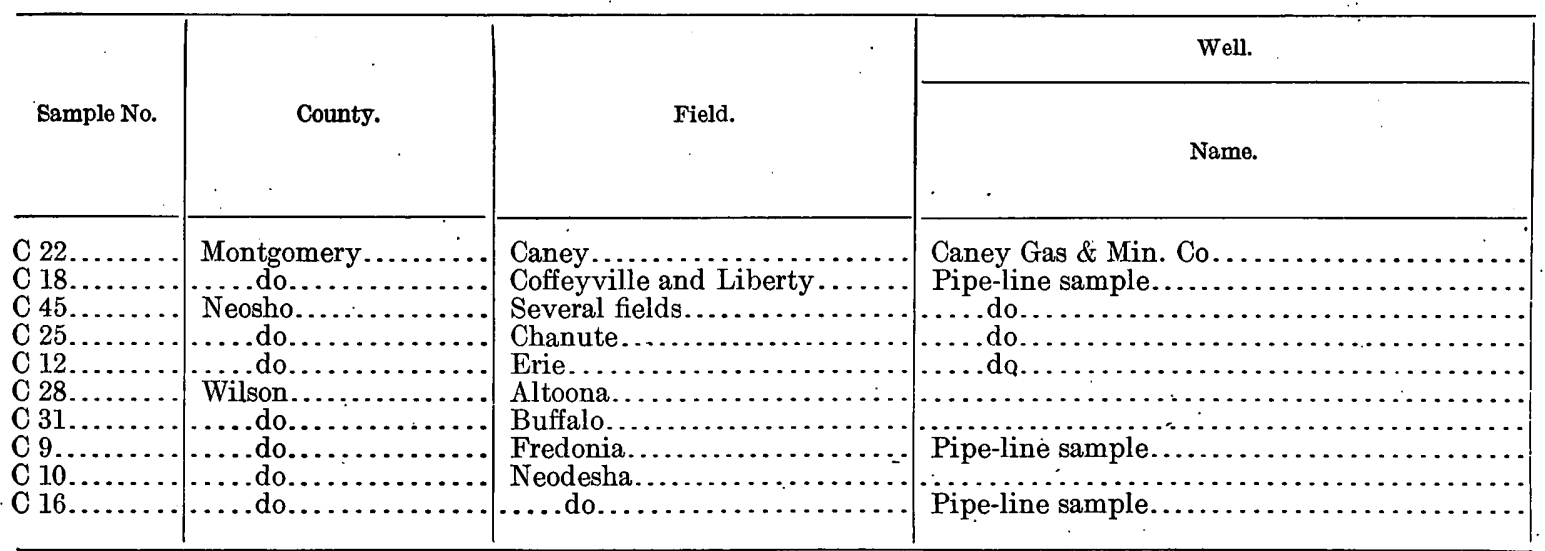

\begin{tabular}{|c|c|c|c|}
\hline \multicolumn{4}{|c|}{ Louisiana. } \\
\hline $\begin{array}{l}W \ldots \ldots \ldots \\
W \ldots \ldots \ldots \\
\mathrm{W} \quad \ldots 6 \ldots \ldots \ldots \\
\mathrm{W} \ldots \ldots \ldots \ldots \\
\mathrm{W} \ldots \ldots \ldots \ldots \\
\mathrm{W} \ldots \ldots \ldots \ldots \\
\mathrm{W} \ldots \ldots \ldots \ldots\end{array}$ & 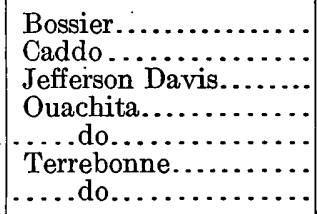 & 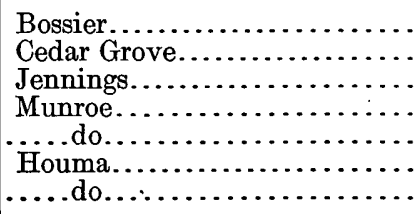 & 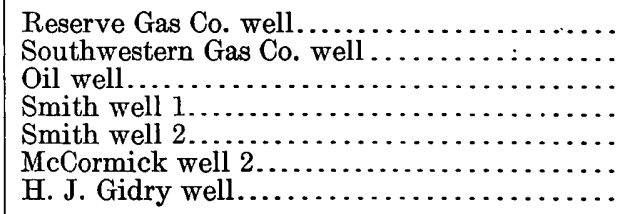 \\
\hline \multicolumn{4}{|c|}{ Missouri. } \\
\hline $\begin{array}{l}\text { C } 43 \ldots \ldots \ldots \\
\text { C } 44 \ldots \ldots \ldots\end{array}$ & 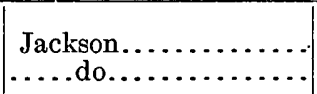 & Sheffield $\ldots \ldots \ldots \ldots \ldots \ldots \ldots \ldots \ldots \ldots \ldots$ & 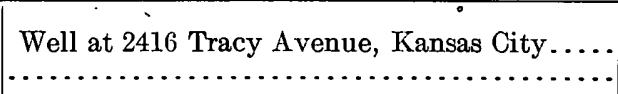 \\
\hline \multicolumn{4}{|c|}{ Montana. } \\
\hline $\begin{array}{l}\text { A } 2 \ldots \ldots \ldots . \\
\text { A } 1 \ldots \ldots \ldots \ldots \\
\text { A } 5 \ldots \ldots \ldots \ldots\end{array}$ & $\begin{array}{l}\text { Dawson } \ldots \ldots \ldots \ldots \ldots \\
\text { Fallon } \ldots \ldots \ldots \ldots \ldots \\
\text { Hill } \ldots \ldots \ldots \ldots \ldots \ldots\end{array}$ & 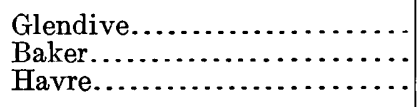 & 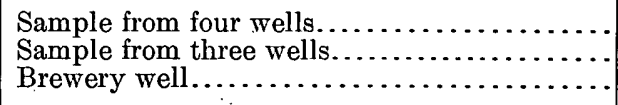 \\
\hline
\end{tabular}

\begin{tabular}{|c|c|c|c|}
\hline & . & North Dakota. & \\
\hline$A 3 \ldots \ldots \ldots$ & Ward.......... & 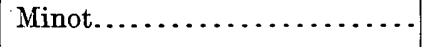 & $\cdots \ldots \ldots \ldots \ldots \ldots \ldots$ \\
\hline \multicolumn{4}{|c|}{ Ohio. } \\
\hline Ri 10... & Hocking.... & Vinton..... & W. A. Williamson well.... \\
\hline $\mathrm{Ri} 11 \ldots$ & $\ldots .$. do......... & $\ldots$ do..... & Mahlon Paxton well..... \\
\hline $\mathrm{C} 24 \ldots$ & Richland ......... & Butler............... & $\mathrm{F}:$ O. Levering well . . . . . . . . . . . . . \\
\hline W.... & Vinton............ & Vinton................... & Pipe-line sample.................. \\
\hline Ri $0 .$. & ....do........ & .....do..... & \\
\hline Ri 1.. & .....do. & $\ldots \ldots$ do............ & Ohio Fuel Supply Co. well $1592 \ldots \ldots \ldots$ \\
\hline $\mathrm{Ri} 2$. & ....do. & $\ldots$. do.............. & Ohio Fuel Supply Co. well $1737 \ldots$... \\
\hline $\mathrm{Ri} 3$. & .....do.. & .... do..... & Ohio Fuel Supply Co. well $1919 \ldots$ \\
\hline $\mathrm{Ri} 4$. & .....do.. & .... do..... & Ohio Fuel Supply Co. well $2109 \ldots \ldots \ldots$ \\
\hline $\mathrm{Ri} 5$. & ....do.. & .... do..... & Ohio Fuel Supply Co. well $1634 \ldots \ldots$.... \\
\hline $\mathrm{Ri} 6$. & .....do.. & .....do...... & 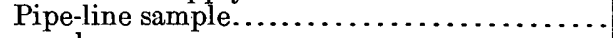 \\
\hline Ri 7. & .....do. . & ....do..... & . do. $\ldots \ldots \ldots \ldots \ldots \ldots \ldots \ldots \ldots$ \\
\hline $\mathrm{Ri} 8$. & ..do. . & ....do..... & Oil Fuel Supply Co. well $2364 \ldots$... \\
\hline Ri 9. & do. & .....do..... & Oil Fuel Supply Co. well $2140 \ldots$... \\
\hline Ri 15. & ..do.. & $\ldots$. do..... & Oil Fuel Supply Co. well $2281 \ldots$... \\
\hline $\operatorname{Ri} 16$. & . do.... & .....do..... & Ohio Fuel Supply Co. well 1991.... \\
\hline $\mathrm{Ri}]$ & . . do... & .... do...... & Ohio Fuel Supply Co. well $2224 \ldots$... \\
\hline Ri 19. & do.. & .... do..... & Ohio Fuel Supply Co. well $1779 \ldots \ldots \ldots \ldots$ \\
\hline Ri 20. & $\therefore$ do. & .....do...... & Ohio Fuel Supply Co. well $1788 \ldots \ldots \ldots \ldots$ \\
\hline Ri 21. & .do. & $\because \ldots$ do..... & Ohio Fuel Supply Co. well $634 \ldots . . \ldots \ldots \ldots$ \\
\hline Ri 22 . & do.. & $\ldots \ldots \ldots \ldots \ldots$ & Ohio Fuel Supply Co. well $2727 . \ldots \ldots \ldots \ldots$ \\
\hline $\operatorname{Ri} 23$. & $\ldots \ldots$ do $\ldots \ldots \ldots \ldots \ldots$ & $\therefore \ldots$ do $\ldots \ldots \ldots \ldots \ldots \ldots . . . . . .$. & Ohio Fuel Supply Co. well $2062 . . . \ldots \ldots$. . . \\
\hline W... & Washington.......... & 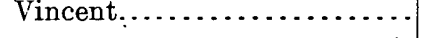 & W. H. Bell well....................... \\
\hline
\end{tabular}


tested for helium-Continued.

Kansas-C ontinued.

\begin{tabular}{|c|c|c|c|c|c|c|c|c|}
\hline \multicolumn{5}{|c|}{ Woll-Continued. } & \multicolumn{2}{|c|}{ Producing sand. } & \multirow{3}{*}{ Date sampled. } & \multirow{3}{*}{ Helium (per } \\
\hline \multicolumn{3}{|c|}{ Locality. } & \multirow{2}{*}{$\begin{array}{l}\text { Rock pres- } \\
\text { sure (pounds } \\
\text { per square } \\
\text { inch). }\end{array}$} & \multirow{2}{*}{$\begin{array}{l}\text { Open flow } \\
\text { (M cubic } \\
\text { feet). }\end{array}$} & \multirow{2}{*}{ Age. } & \multirow{2}{*}{ Depth (feet). } & & \\
\hline Section. & Township. & Rango. & & & & & & \\
\hline 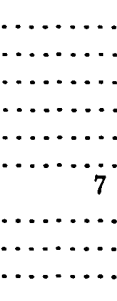 & 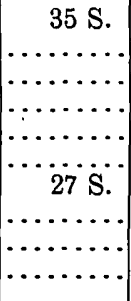 & 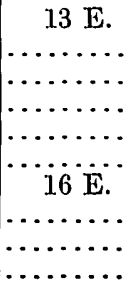 & 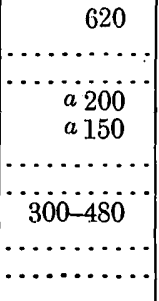 & 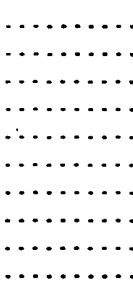 & 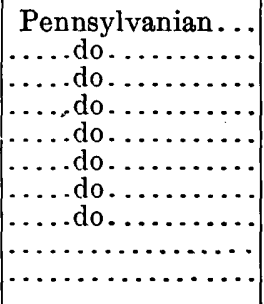 & 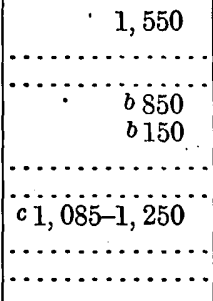 & $\begin{array}{l}\text { July } \quad 14,1906 \\
1906 . . . \ldots \ldots \\
\text { Dec. } 12,1906 \\
\text { July } 24,1906 \\
\text { July } \quad 3,1906 \\
\text { July } 25,1906 \\
\text { July } 28,1906 \\
\text { 1906. } \ldots \ldots \ldots . \\
\text { June } 27,1906 \\
\text { 1906......... }\end{array}$ & $\begin{array}{l}0.08 \\
.08 \\
.17 \\
.24 \\
.13 \\
.26 \\
.27 \\
.62 \\
.10 \\
.27\end{array}$ \\
\hline & & 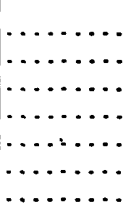 & 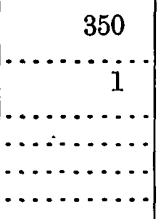 & 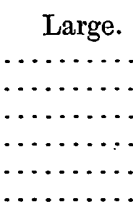 & 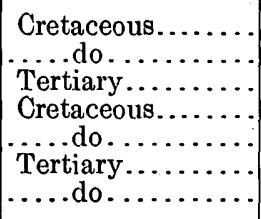 & 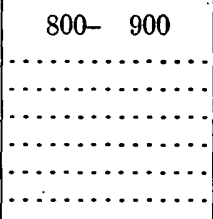 & $\begin{array}{l}1918 \ldots \ldots \ldots \\
1918 \ldots \ldots \\
\text { Feb. } \ldots, 1907 \\
1918 \ldots \ldots \ldots \\
1918 \ldots \ldots \ldots \\
1918 \ldots \ldots \ldots \\
1918 \ldots \ldots \ldots\end{array}$ & $\begin{array}{r}.028 \\
.046 \\
\text { Trace. } \\
.053 \\
.075 \\
\text { Trace. } \\
\text { Trace. }\end{array}$ \\
\hline \multicolumn{9}{|c|}{ Missouri. } \\
\hline & & & $\cdots \cdots 0_{40}$ & $\begin{array}{l}0.5 \\
1.6\end{array}$ & 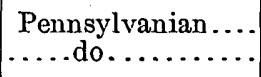 & $\begin{array}{c}300 \\
\text { Shallow. }\end{array}$ & $\begin{array}{l}1906 \ldots \ldots \ldots \\
1906 \ldots \ldots \ldots\end{array}$ & $\begin{array}{l}.013 \\
.041\end{array}$ \\
\hline \multicolumn{9}{|c|}{ North Dakota. } \\
\hline & & $\ldots \ldots$. & 5 & 35 & Cretaceous........ & 357 & Aug. 15,1918 & .17 \\
\hline
\end{tabular}

Ohio.

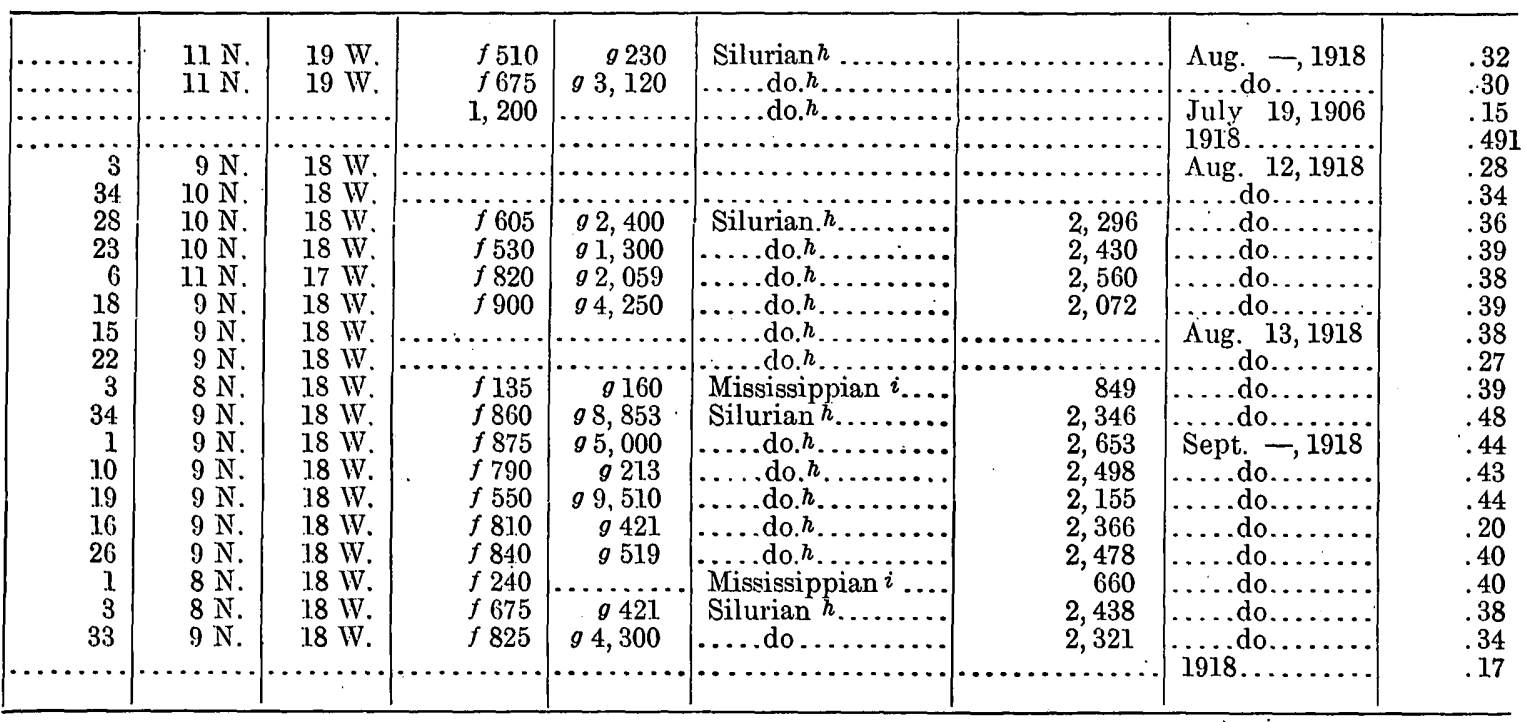


Oklahoma.

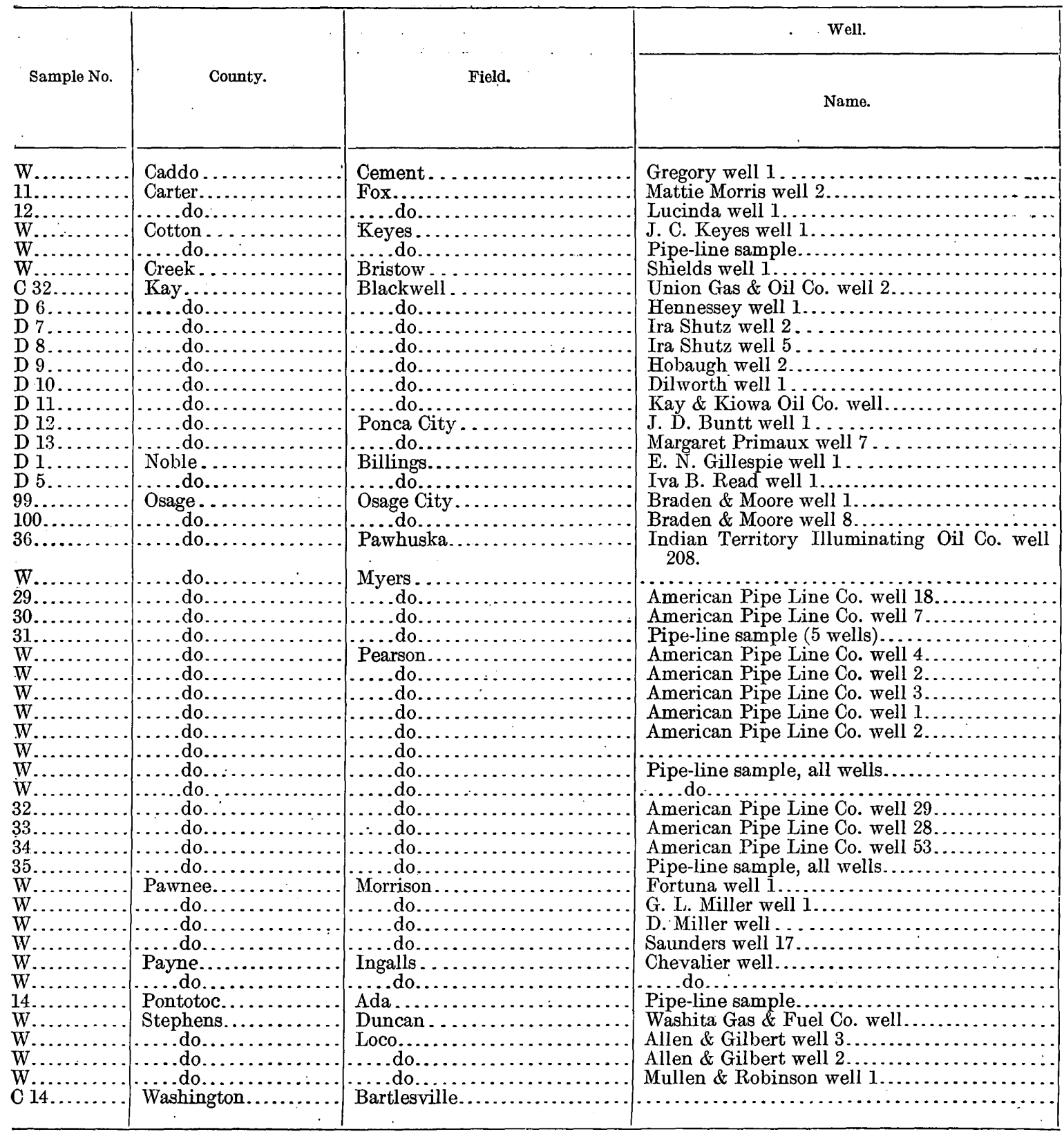

South Dakota.

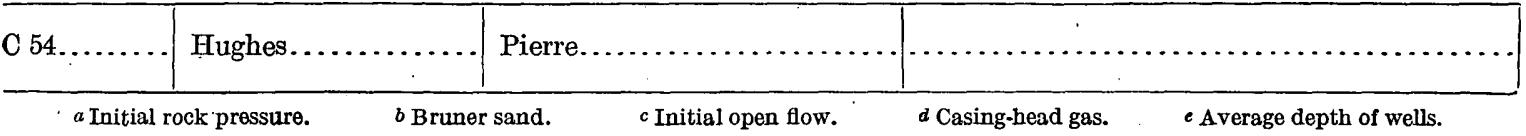


tested for helium-Continued.

Oktahoma.

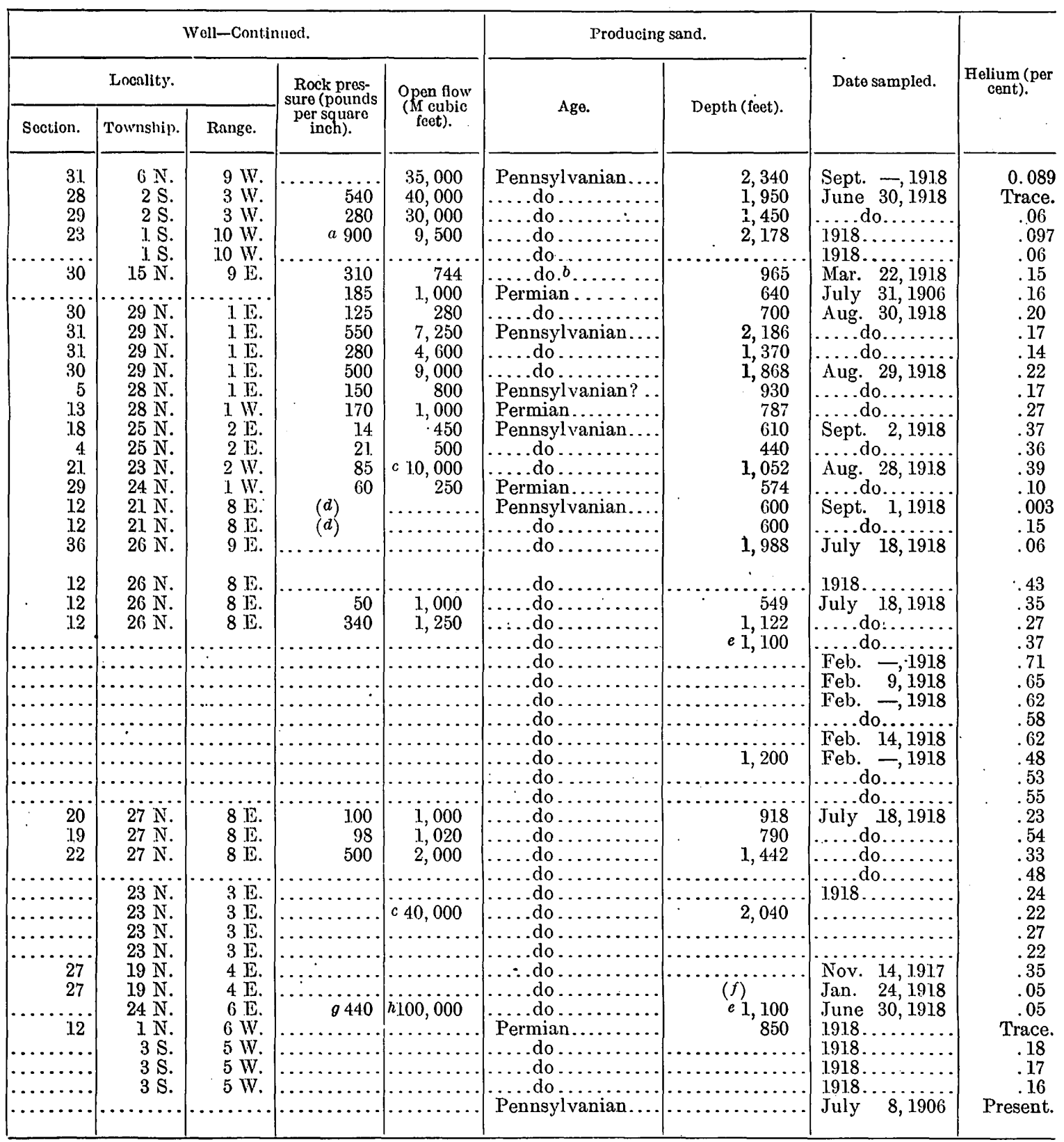

South Dakota.

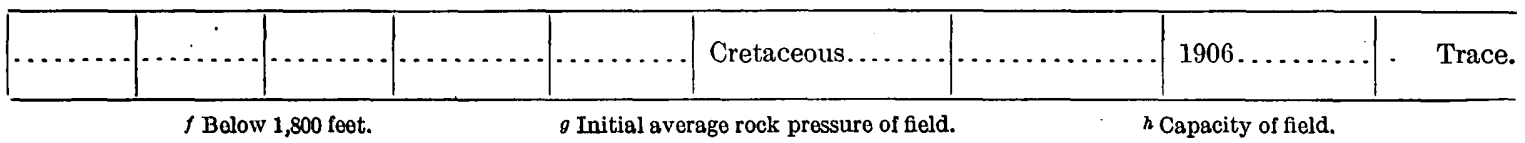


Texas.

\begin{tabular}{|c|c|c|c|}
\hline & & & Well. \\
\hline Sample No. & County. & Field. & Name. \\
\hline & Brown . & Bangs . . . . . . . . . . . . . & Fuller well $\ldots \ldots \ldots \ldots \ldots \ldots \ldots \ldots \ldots$ \\
\hline & .....do. & ....do $\ldots . . . . . . . . . . .$. & McGee well $\ldots \ldots \ldots \ldots \ldots \ldots \ldots \ldots \ldots \ldots$ \\
\hline & Clay..... & Petrolia.....$\ldots \ldots \ldots \ldots$ & Pipe-line sample.................... \\
\hline C. & .... do. & 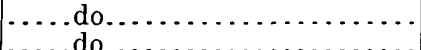 & 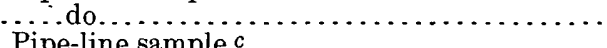 \\
\hline 1. & ...dodo.............. & 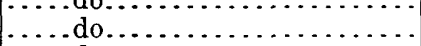 & Miller well $4 . \ldots \ldots \ldots \ldots \ldots \ldots \ldots \ldots \ldots \ldots$ \\
\hline & $\ldots \ldots$ do........... & 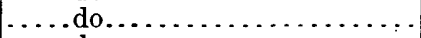 & Smith \& Weber well 1 . . . . . . . . . \\
\hline & do... & $\ldots \ldots \ldots \ldots \ldots \ldots$ & Holloway well $7 \ldots \ldots \ldots \ldots \ldots \ldots \ldots$ \\
\hline & ...do... & $\ldots \ldots \ldots \ldots \ldots . . . .$. & Landrum well $2 \ldots \ldots \ldots \ldots \ldots \ldots \ldots$ \\
\hline & ..do.... & $\ldots \ldots \ldots \ldots \ldots$ & Holt well $1 \ldots \ldots \ldots \ldots \ldots \ldots \ldots \ldots \ldots . . . \ldots \ldots$ \\
\hline & . do.... & $\ldots \ldots \ldots \ldots$. & Byers well $5 \ldots \ldots \ldots \ldots \ldots \ldots \ldots \ldots \ldots$ \\
\hline & ....do... & ....do..................... & Stive Oil \& Gas Co. well $1 \ldots \ldots \ldots \ldots \ldots$ \\
\hline & .....do... & $\ldots \ldots \ldots \ldots \ldots$ & H. D. Stive well................... \\
\hline & $\ldots$. do.......... & $\ldots \ldots \ldots \ldots$. & Skelly well................. \\
\hline 10. & $\ldots$ do......... & $\ldots$, do $\ldots \ldots \ldots \ldots \ldots \ldots . . . .$. & Martin well $5 \ldots \ldots \ldots \ldots \ldots \ldots \ldots \ldots$ \\
\hline W. & Coleman....... & Trickham................. & Robiuson well $2 \ldots \ldots \ldots \ldots \ldots \ldots \ldots$ \\
\hline 68 . & $\ldots$ do........... & Coleman............. & Wood \& Wooley well 1.............. \\
\hline 46. & Eastland........... & 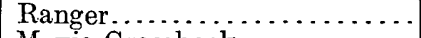 & Brashear well $1 \ldots \ldots \ldots \ldots \ldots \ldots \ldots \ldots$ \\
\hline & Limestone....... & Mexia-Groesbeck........ & 4 samples from different wells. ......... \\
\hline 47 & Palo Pinto........... & Mineral Wells................ & G. W. Dye well $1 \ldots \ldots \ldots \ldots \ldots \ldots \ldots \ldots \ldots$ \\
\hline 48. & ..... do... & $\ldots$. do $\ldots \ldots \ldots \ldots \ldots \ldots$ & Ḣolt well $1 \ldots \ldots \ldots \ldots \ldots \ldots \ldots \ldots$ \\
\hline $\begin{array}{l}49 . \\
50 .\end{array}$ & $\begin{array}{l}\ldots \text { do } \ldots \ldots \ldots \\
\ldots \ldots \text { do } \ldots \ldots \ldots\end{array}$ & 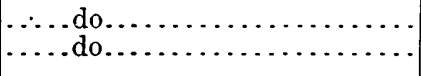 & $\begin{array}{l}\text { Frank Corn well } 1 \ldots \ldots \ldots \ldots \ldots \ldots \ldots \ldots \ldots \\
\text { Jacques well } 1 . \ldots \ldots \ldots \ldots \ldots \ldots \ldots \ldots\end{array}$ \\
\hline 54. & . do............. & ....do....... & 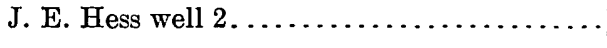 \\
\hline & .do.. & .....do. & D. A. Hess well $1 \ldots \ldots \ldots \ldots \ldots \ldots \ldots$ \\
\hline 56. & ..... do... & .....do... & J. E. Hess well $1 \ldots \ldots \ldots \ldots \ldots \ldots \ldots$ \\
\hline 57. & .....do... & .....do... & Edmundson well $1 \ldots \ldots \ldots \ldots \ldots \ldots \ldots \ldots$ \\
\hline $60 \ldots \ldots \ldots \ldots$ & $\begin{array}{l}\ldots \text { do } \ldots \ldots \ldots \\
\ldots \ldots \text { do } \ldots \ldots \ldots \text {. }\end{array}$ & Strawn $\ldots \ldots \ldots \ldots \ldots \ldots \ldots \ldots \ldots$ & $\begin{array}{l}\text { Gill well } 1, \ldots \ldots \ldots \ldots \ldots \\
\text { Pierce well } 2 \ldots \ldots \ldots \ldots \ldots \ldots\end{array}$ \\
\hline 40. & .....do.. & .....do... & Robinson well $2 \ldots \ldots \ldots \ldots \ldots \ldots \ldots$ \\
\hline & .....do.. & .....do... & Unkhart well $271 \ldots \ldots \ldots \ldots \ldots \ldots \ldots$ \\
\hline 42. & .....do... & .... do... & Pipe-line sample................. \\
\hline 72. & ....do........... & $\ldots \ldots$ do $\ldots \ldots \ldots \ldots \ldots \ldots \ldots \ldots$ & Stewart well $75 \ldots \ldots \ldots \ldots \ldots \ldots \ldots \ldots \ldots \ldots$ \\
\hline & Shackelford.... & Moran. . & Formby-Tarrant well $1 . \ldots .$. \\
\hline & $\ldots$. do $\therefore . .$. . & .....do.. & Pipe-line sample (all wells). ......... . \\
\hline & ... . do... & .....do.. & Edwards well $1 \ldots \ldots \ldots \ldots \ldots \ldots \ldots$ \\
\hline & ... do... & .....do.. & Cottle well $1 . \ldots \ldots \ldots \ldots \ldots \ldots \ldots$ \\
\hline 67. & $\ldots$. do......... & $\ldots \ldots$ do $\ldots . . . \ldots \ldots \ldots . .$. & Pipe line, 11 wells................. \\
\hline 43 . & $\begin{array}{l}\text { Stephens............. } \\
\text {.....do.............. }\end{array}$ & 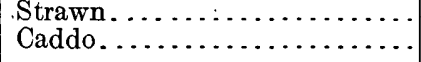 & $\begin{array}{l}\text { See Palo Pinto County } \ldots \ldots \ldots \ldots \ldots \ldots \ldots \\
\text { Coody well } 1 . \ldots \ldots \ldots \ldots \ldots \ldots\end{array}$ \\
\hline 39. & $\ldots$ do................ & La Casa.................... & Rainey well $1 \ldots \ldots \ldots \ldots \ldots \ldots \ldots \ldots$ \\
\hline 73. & $\ldots$. do.............. & $\ldots$ do.................. & Adams well $1 . \ldots \ldots \ldots \ldots \ldots \ldots \ldots$ \\
\hline W. & $\ldots$...do........ & Breckenridge.............. & Smith well $1 . \ldots \ldots \ldots \ldots \ldots \ldots \ldots \ldots$ \\
\hline W. & Throckmorton.... & 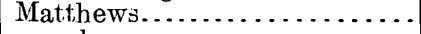 & Texas Co. well $4 \ldots \ldots \ldots \ldots \ldots \ldots \ldots \ldots . . . \ldots$ \\
\hline W. & $\ldots$... do............. & $\ldots \ldots$ do....................... & Texas Co. well $m \ldots \ldots \ldots \ldots \ldots \ldots \ldots$ \\
\hline W....... & Zapata............ & Jennings. . . . . . . . . . . . . . & 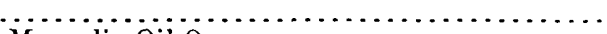 \\
\hline W...... & Williamson.......... & 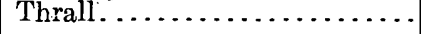 & Magnolia Oil Co......................... \\
\hline
\end{tabular}

Washington.

\begin{tabular}{|c|c|c|c|}
\hline A $9 . \ldots \ldots \ldots$ & Benton............ & Prossor. . . . . . . . . . & $\ldots$ \\
\hline & $\begin{array}{l}a \text { Strawn form } \\
b \text { Cisco formati } \\
c \text { Analysis by } \\
d \text { June } 1,1918 . \\
e \text { January } 1,19 \\
f \text { Initial open } \\
g \text { Lower part o } \\
h \text { Contact betr }\end{array}$ & $\begin{array}{l}\text { ation. } \\
\text { ion. } \\
\text { Moore and Yancey, Bureau of Mines Ex } \\
\text { 918. } \\
\text { fow. } \\
\text { f Canyon formation or upper part of Stra } \\
\text { veen Marble Falls limestone and Smithw }\end{array}$ & $\begin{array}{l}\text { speriment Station, Golden, Colo. } \\
\text { awn formation. } \\
\text { Fick shale. }\end{array}$ \\
\hline
\end{tabular}


tested for helium-Continued.

Texas.

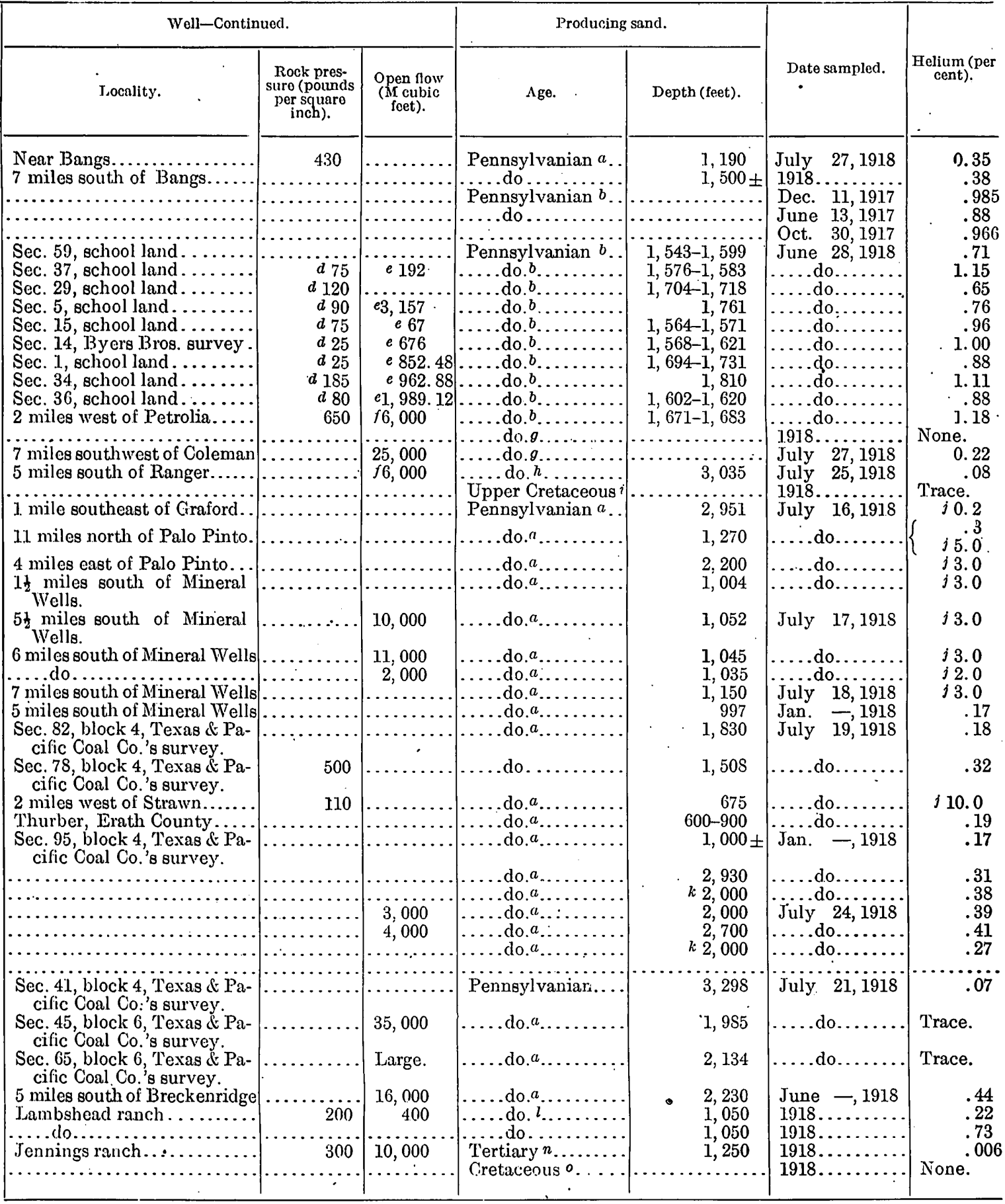

Washington.

\begin{tabular}{|l|r|r|r|r|r|r}
\hline$\ldots \ldots \ldots \ldots \ldots \ldots \ldots \ldots$ & 5 & 4,500 & Tertiary $p \ldots \ldots \ldots$ & 730 & Aug. 19,1918 & 0.06 \\
\hline
\end{tabular}

- Nacatoch sand member of Navarro formation.

f Nitrogen.

$\boldsymbol{k}$ Average depth of wells.

$l$ Possibly Cisco formation.

$m$ Number of well doubtful.

n Yegua formation, Eocene. $p$ Gas from sand beneath Tertiary lava flow. 
West Virginia.

Data on samples of natural gas

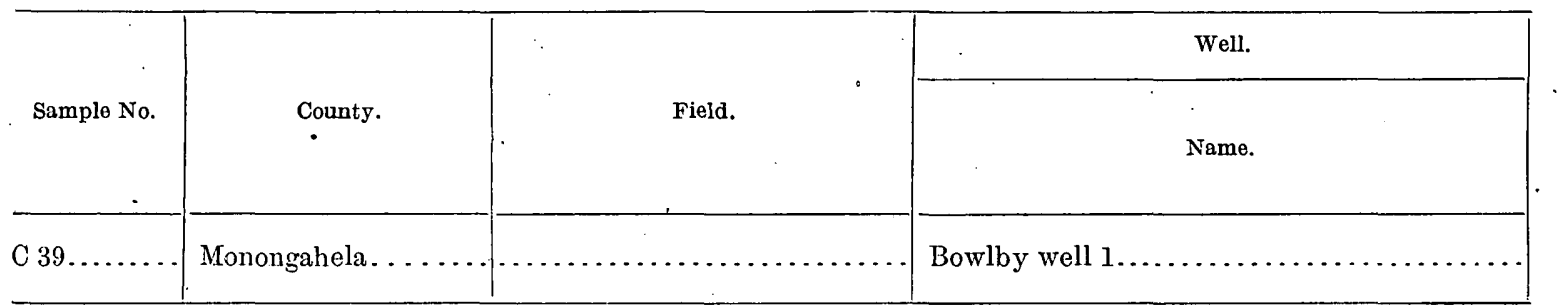

Wyoming.

\begin{tabular}{|c|c|c|}
\hline$F 5 \ldots \ldots$. & Big Horn ............ & Lamb dome... . . . . . . . \\
\hline $6 \ldots$ & ... do............. & Bryon.................. \\
\hline F 13. & Carbon.............. & Allen Lake.......... \\
\hline $\mathrm{F} 14$. & .... do............. & $\ldots$. do........... \\
\hline F 11 . & Freemont........... & Big Sand Draw......... \\
\hline $\mathrm{F} 9$ & Hot Springs. . . . . . . & Buffalo Basin........... \\
\hline $\mathbf{F} 10$ & $\ldots \ldots$ do:......... & Grass Creek......... \\
\hline W... & Natrona......... & Emigrant Gap........ \\
\hline W... & $\ldots \ldots$ do $\ldots . . . .$. & ....do............. \\
\hline F 1 . & .....do.. & Salt Creek........ \\
\hline F 2. & .....do. & Powder River... . . . . . . \\
\hline F 3 . & ....do.. & Pine Mountain............ \\
\hline F 7 . & Park.... & Oregon Basin............ \\
\hline F $8 \ldots$ & ... do..... & 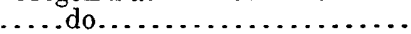 \\
\hline $\mathrm{F} 12 \ldots$. & Sweetwater..... & Dry Lake....... \\
\hline F $4 \ldots \ldots$ & Washakie............. & Hidden Dome . . . . . . . . . \\
\hline
\end{tabular}

Pipe-line sample, five wells.

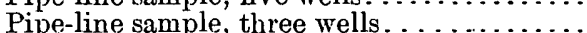

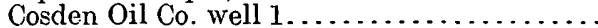

Producers \& Refiners' Co. well j. . . . . . . . . . . . .

McFarlane well.

Pipe-line saniple

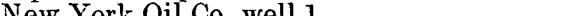

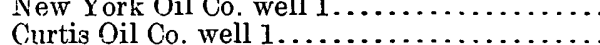

Pipe-line sample.

Ohio Oil Co two wells.....

Pine Mountain Dome Oil Co. well $1 \ldots . . . .$.

Well 5.

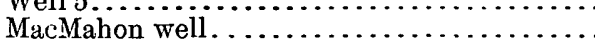

John Hay well 1 .

Tensleep well $2 \ldots \ldots \ldots \ldots \ldots \ldots \ldots \ldots$ 
tested for helium-Continued.

West Virginia.

\begin{tabular}{|c|c|c|c|c|c|c|c|c|}
\hline \multicolumn{5}{|c|}{ Woll-Continued. } & \multicolumn{2}{|c|}{ Producing sand. } & \multirow{3}{*}{ Date sampled. } & \multirow{3}{*}{$\begin{array}{l}\text { Helium (per } \\
\text { cent). }\end{array}$} \\
\hline \multicolumn{3}{|c|}{ Locality. } & \multirow{2}{*}{$\begin{array}{l}\text { Rock pres- } \\
\text { sure (pounds } \\
\text { per squaro } \\
\text { inch). }\end{array}$} & \multirow{2}{*}{$\begin{array}{l}\text { Open flow } \\
\text { (M cubic } \\
\text { feet). }\end{array}$} & \multirow{2}{*}{ Age. } & \multirow{2}{*}{ Depth (feet). } & & \\
\hline Soction. & 'Township. & Range. & & & & & & \\
\hline \multicolumn{3}{|c|}{10 miles west of Morgantown. } & 160 & $\ldots \ldots \ldots \ldots$ & Mississippian $a_{\ldots} \ldots$ & 1,800 & Aug. 18, 1906 & 0.09 \\
\hline
\end{tabular}

Wyoming.

\begin{tabular}{|c|c|c|c|c|c|c|c|c|}
\hline 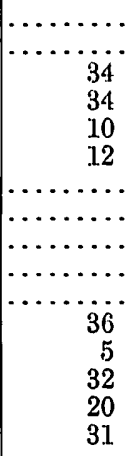 & 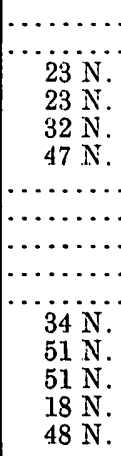 & $\begin{array}{r}79 \mathrm{~W} . \\
79 \mathrm{~W} . \\
95 \mathrm{~W} . \\
100 \mathrm{~W} . \\
\ldots \ldots \ldots . \\
\ldots \ldots \ldots \ldots \\
\ldots \ldots \ldots \ldots \\
\ldots \ldots \ldots \\
83 \mathrm{~W} . \\
100 \mathrm{~W} . \\
100 \mathrm{~W} . \\
103 \mathrm{~W} . \\
90 \mathrm{~W} .\end{array}$ & 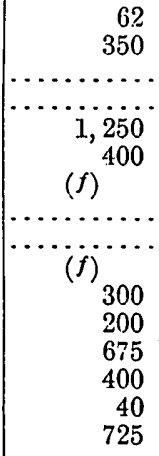 & $\begin{array}{c}b 19,000 \\
b 100,000 \\
\cdots \ldots \ldots . \\
\cdots \ldots \ldots \\
8,000 \\
b 100,000 \\
3,000 \\
\cdots \ldots \ldots \ldots \\
\cdots \ldots \ldots \ldots \\
b 12,000 \\
2,250 \\
1,000 \\
16,000 \\
3,000 \\
2.5 \\
4,000\end{array}$ & 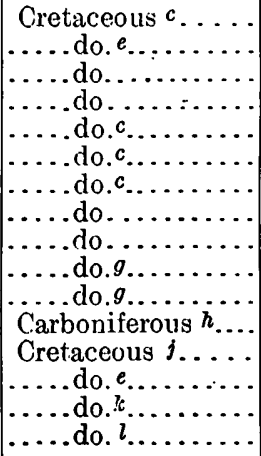 & \begin{tabular}{r}
$d 500$ \\
$1,550-1,840$ \\
1,357 \\
947 \\
2,412 \\
1,700 \\
$d 700-1,200$ \\
$\ldots \ldots \ldots . .$. \\
\hdashline$\ldots \ldots 0.2,250$ \\
$1,000-2,1,267$ \\
1,668 \\
1,345 \\
1,300 \\
2,390 \\
1,045
\end{tabular} & 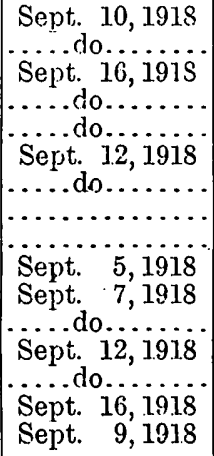 & $\begin{array}{l}\text { Trace. } \\
\text { Trace. } \\
\text { None. } \\
\text { None. } \\
\text { Trace. } \\
0.07 \\
\text { Trace. } \\
\text { Trace. } \\
\text { Trace. } \\
\text { None. } \\
\text { Trace. } \\
\text { i0. } 26 \pm \\
\text { Trace. } \\
0.09 \\
\text { Trace. } \\
\text { Trace. }\end{array}$ \\
\hline
\end{tabular}

o Wall Creek sandstone member of Frontier formation, Colorado group.

i Sample lost during analysis, but helium content closely estimated.

1 Greybull sand, Lower Cretaceous.

Dakota (?) formation, Lower Cretaceous.

$\imath$ Colorado group (Frontier (?) formation). 


\section{INDEX.}

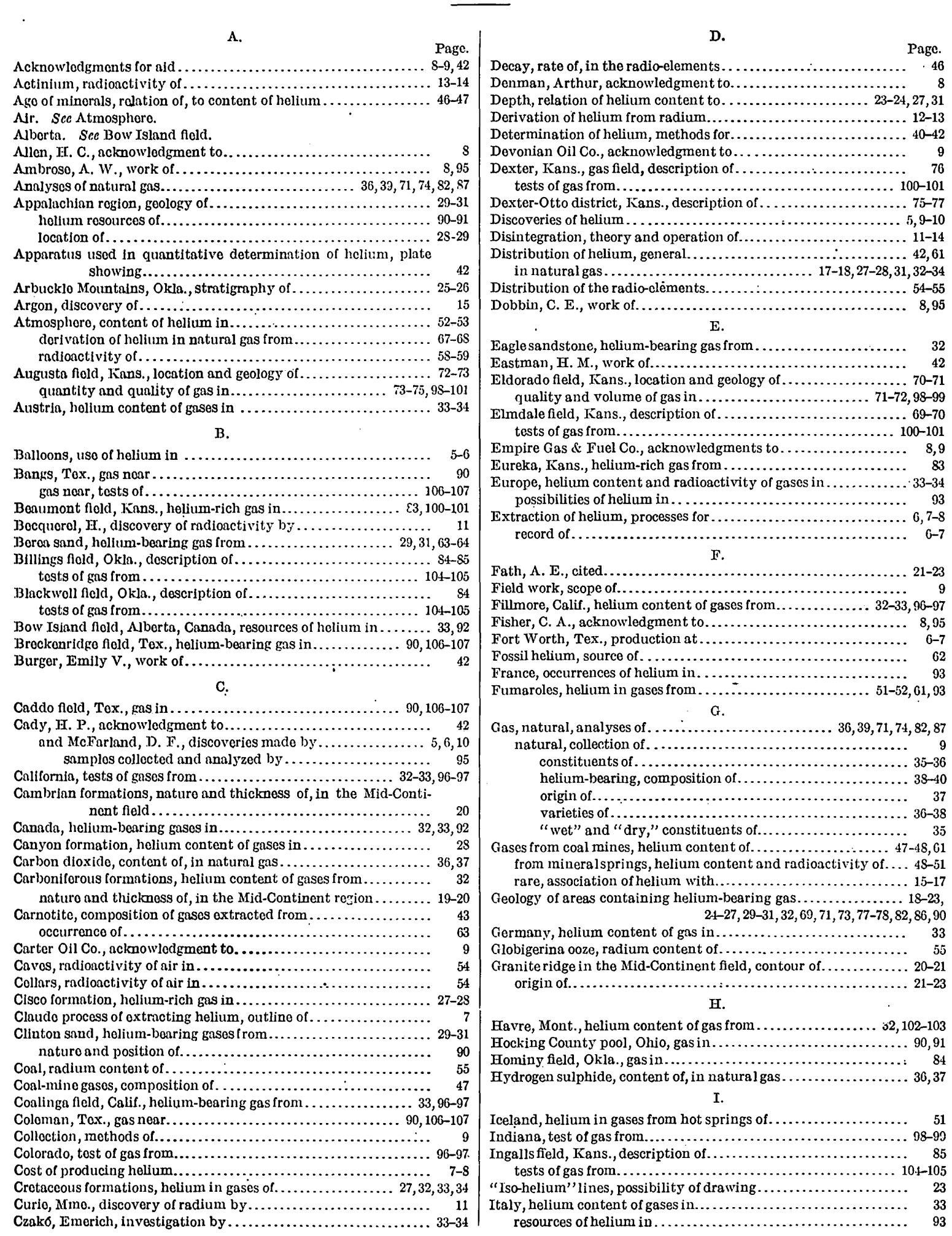


Jeffries-Norton process of extracting helium, outline of....... 7 K.

Kansas, area of helium-bearing gas in minor gas fields in. production of naturalgas in.... southern, map of gas fields in tests of gases from .............................. 98 Kansas City group, helium-rich gas in.

Kayser, H., discoveries by. .

\section{L.}

La Casa field, Tex., gas in

Lead, combination of, with helium.

derivation of, from uranium from thorium.

Lewis, J. O., acknowledgment to.

Linde process of extracting helium, outhine

Llano-Burnet area, Tex., stratigraphy of . .................. 25-27

Lockridge well $1, \log$ of..

Lockyer, J. N., discoveries by.

Lone Star Gas Co., acknowledgments to. ................. 8,9

Louisiana, helium content of gases from .............. 27,32;102-103

\section{M.}

McIntosh, Allen, $\log$ of well No. 1 of.....

Map, geologic, of Mid-Continent region........................ of gas fields in southern Kansas and northern Oklahoma.... of oiland gas fieldsin northern Texas and southern Oklahoma.

Matthewsranch, Throckmorton County, Tex.,gas wells on. 89-90, 106-107

Measurement of radioactivity, method of. ................. 53-54

Mid-Continent region, Carboniferous formationsin ............ 19-20 geologic map of.................................. 20

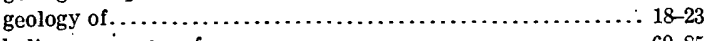
helium resources of................................. 69-85

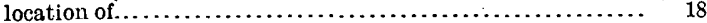
pre-Carboniferous formations in ..................... 20-23 stratigraphic distribution of helium in.................. 23

Migration of helium $\ldots \ldots \ldots \ldots \ldots \ldots \ldots \ldots \ldots \ldots \ldots \ldots \ldots \ldots \ldots, \quad 62$

Military value of helium.............................. $5-6$

Mine gases, helium content of ....................... 47-48, 61

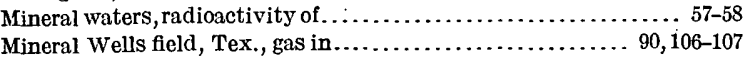

Minerals, helium content of . . ........................ 43-45, 61

Mines, coal, rare gases in fire damp from................... 16-17

Mississippian formations, helium-bearing gas in........... 23,27 occurrence of in the Mid-Continent field $\ldots \ldots \ldots \ldots \ldots \ldots \ldots .20$

Missouri, tests of gases from ........................... 102-103

Moore, R. B., acknowledgment to ..................... 8,42

Monazite, occurrence of ................................ 63

Monett field, Kans., description of $. . . \ldots \ldots \ldots \ldots \ldots \ldots \ldots \ldots \ldots . . \quad 81$

test of gas from ..................................... 100

Montana, tests of gases from......................... 102-103

Moran field., Tex., helium-bearing gas in.............. 90,106-107

Morrison field, Okla., description of . ...................... 85

tests of gases from............................. 104-105

Moureu, Charles, researches by ....................... 48-51

Myers field, Okla., description of ......................... $81-82$

\section{N.}

Neon, discovery and properties of $\ldots \ldots \ldots \ldots \ldots \ldots \ldots \ldots \ldots \ldots .15$

Nitrogen, association of helium with ...................... 64-65 content of , in natural gas.......................... 18, 36, 37 relation of, to helium in gases of mineral springs........... 50

to helium in natural gas........................ $38-40,84$

separation of from helium ......................... 40-42

source of in mineral gases........................... 37,67

North Dakota, test of gas from ........................ 102-103

North Texas. See Texas, northern.

O.

Occurrences of helium, summary of.

Chio area, distribution of helium in

geology of.

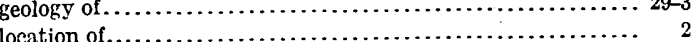

tests of gases from

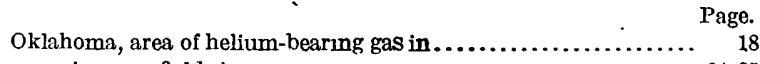
minor gas fields in ................................. 84-85 northern, map of gas fields in ......................... 18 production of natural gas in $. . . \ldots \ldots \ldots \ldots \ldots \ldots \ldots \ldots \ldots . . \quad 83$ southern, map of oii and gas fields in ...................... 24 tests of gases from. ................................. 104-105

Oklahoma Natural Gas Co., acknowledgment to.......... 8 Ordovician formations in the Mid-Continent field............... 20 Origin of helium . . . . . . . . Osage Count $y$, Okla., fields in $. \ldots \ldots \ldots \ldots \ldots \ldots \ldots \ldots \ldots \ldots \ldots . \ldots 1-83$

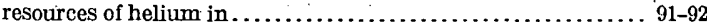
Otto, Kans., gas wells near, tests of gas from............... 77,100

\section{P.}

Pacific Coast region, helium content of gases in ............. 32-33, 91 Pearson field, Okla, description of ......................... 81 resources of helium in ................................. 91-92

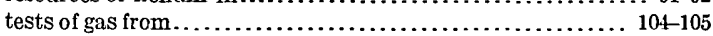
Pechelbronn, Alsace, helium content of gas near................ 33-34 volume of gas near ....................................... 92

Pennsylvanian formations, helium-rich gases in . . . . . . . . 23, 27-28 occurrence of, in the Mid-Continent field. . ................ 19-20 Pcrmian formations, helium-bearing gases in ................. 23, 27-28

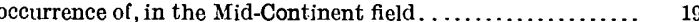

Petrolia field, Tex., composition of gas in.................. 86-87 duration of supply in ................................ $87-89$ location and geology of ................................... $85-86$ production from $\ldots \ldots \ldots \ldots \ldots \ldots \ldots \ldots \ldots \ldots \ldots \ldots \ldots, 7,87$ tests of gas from

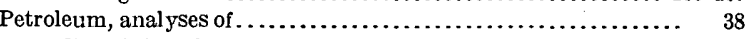
radioactivity of ..................................... 58

Pine Mountain, Wyo., helium content of gas from............. 32 Pitchblende, composition of gases extracted from............... 43

Ponca City field, Okla., description of........................ 84 tests of gas from. . . d................................... 104-105

Potassium, radioactivity of ................................ 14

Potassium salts, helium content of ......................... 45

Pre-Cambrian granite, depth to, in the Mid-Continent field......... 20-23

Pre-Carboniferous formations in the Mid-Continent field.......... 20-23

Primordial helium, probability of . ...................66-67,68

Production of helium, natural, estimates of. . . . . . . . . . . . . . . 59-60 natural, rate of.. See also Extraction of helium.

Properties of helium................................ $6,10-11$ R.

Radioactivity, measurement of........................ 53-54 of mineral waters.................................... 57-58 of natural gas............................................ 58

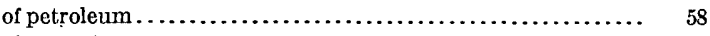
of sea water $. \ldots \ldots \ldots \ldots \ldots \ldots \ldots \ldots \ldots \ldots \ldots \ldots \ldots \ldots \ldots \ldots \ldots \ldots \ldots, \quad 59$

of the atmospherc.................................. 58-59 phenomena and theory of ........................... 11-14 presence of helium inferred from...................... 53,61 relation of, to content of helium ........................ $45,47,48-50$ Radio-elements, derivation of helium from . . .............. $62-66,68$ distribution of .................................. 54-59

Radiolarian ooze, radium content of....................... $\quad 55$

Radium, content of, in rocks.......................... 54-56 content of, in sea water.............................. 59 derivation of, from uranium....................... 12-13 derivation of helium from........................... 12-13 discovery of...

Ramsay, J. B., work of................................ ${ }_{42}$

Ramsay, William, discoveries by............................. $9-10,15$

Ranger field, Tex., gas in.............................. 90, 106-107

Resources of helium in the United States.................... 91-92 outside of the United States............................. 92-93

Richardson, George B., cited............................ 31 work of $\ldots \ldots \ldots \ldots \ldots \ldots \ldots \ldots \ldots \ldots \ldots \ldots \ldots \ldots \ldots \ldots, 8,95$

Rocks, helium content of.................................... 45-46, 61 radium content of ......................................... 54-56,61

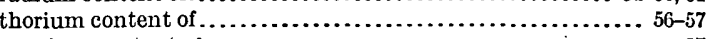
uranium content of................................. 57 Rocky Mountain region, helium content of gases in.......... 32-33, 91 Rogers gas pool, Kans., description of ..................... 77-79 Roundy, P. V., work of ..................................... 8,95

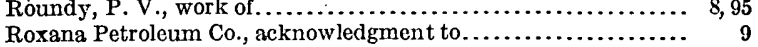
Roxana Petroleum Co., acknowledgment to....................
Rubidium, radioactivity of.................................... Russia, possibilities of helium in . . . . . . . . . . . . . . . . . . . . .

(1)

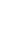


s.

Santa Maria fleld, Calif., holium-bearing gas from.............. 33

Scope of the invostigntion.

Sedan district, Kans., description of.

tosts of gas from.

100-101

description by, of method of determining helium............ $41-42$

tosts made by.

Sespo formation, holium-bearing gas from

Solls, radionctivity of

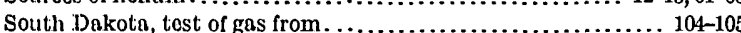

Spheno, helium content of.

Springs, mineral, helium in gases from................. 48-51, 61, 93

minoral, radioactivity of waters of...................... $57-58$ raro gases in.

16-17

hot, holium in gases from

Stars, holium in

radio-olements absent from............................ 53; 61

Stassfurt salts, helium content of.

Stino Oil \& Gas Co., log of well of.......................... 86

Stratigraphic distribution of helium in the north Texas region... 27-28 of holium-rich gases.................................. 23 See also Geology.

Strawn ficld, Tex., gas in......................... 90, 106, 107

Strnwn formation, holium content of gases in.................. 28

Strutt, R. J., rosonrches by............................. 43-46, 54

Summary of occurrences of helium

Sun, helium in.

T.

Tortiary formations, holium content of gases from .............. 32, 33

Tests of gases for helium, catalogue of.

Toxas, northern, distribution of helium in northern, gas fields in.

gas fields in, map showing.

goology of.

locention of.

tests of gases from

$10135^{\circ}-21-8$
Page.

nt to 9

Thorianite, helium content of ............................ 45

Thorium, absence of, from the stars. ......................... 53

association of helium with.......................... 44-45

content of in rocks................................ 56-57

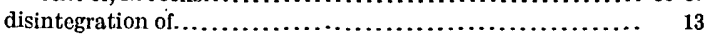

Trickham field, Tex., gas in ..............................

$\mathrm{U}$.

Uranium, absence of, from the stars....................... 53

association of helium with............................. 44-45

derivation of lead from $\ldots \ldots \ldots \ldots \ldots \ldots \ldots \ldots \ldots \ldots \ldots \ldots . . .12-13$

derivation of radium from........................... 12-13

Use of helium in balloons .............................. $5-6$

V.

Van Orstrand, C. E., work of............................ 8

Vesuvius, rare gases in emanations from.................. 16-17

Vinton County ficld, Ohio, gas in. ...................... 90-91

gas in, tests of ................................. 102-103

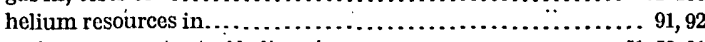

Volcanic gases, content of helium in................... 51-52,61

W.

Wagy, E. W., work of $\ldots \ldots \ldots \ldots \ldots \ldots \ldots \ldots \ldots$

Ward, C. F., work of. ......................................... 8,95

Washington, test of gas from ........................... 106-107

West Virginia, test of gas from.......................... 108-109

White, David, acknowledgment to........................ 8

Wichita Mountains, Okla., stratigraphy of . ................. 25

Wilbarger County, Tex., exhausted wells in................... 89

"Wind" gas, inert constituents of......................... 24, 37

Wyoming, tests of gases from........................... 108-109

$\mathbf{X}$.

Xenon, discovery and properties of........................ 15

$\mathrm{Z}$.

Zircon, helium content of.................................. 45 